Budapesti Corvinus Egyetem

Szociológia Doktori Iskola

SZABÓ JÚLIA

\title{
Erdélyi magyar fiatalok a társadalmi struktúrában
}

Doktori értekezés

Témavezetők:

\author{
Dr. Bartus Tamás
}

Dr. Csata Zsombor

Budapest, 2020 



\section{Tartalomjegyzék}

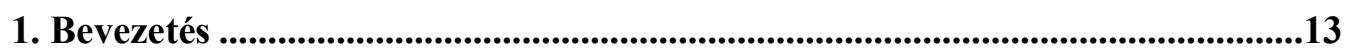

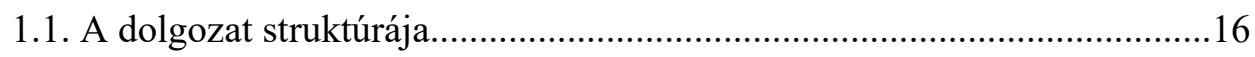

2. Társadalmi rétegződés és osztályszerkezet ..................................................17

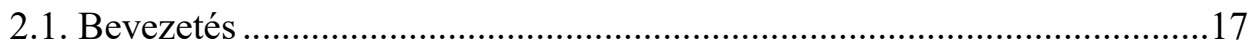

2.2. Foglalkozási osztályszerkezet............................................................ 17

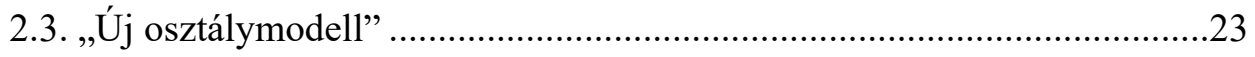

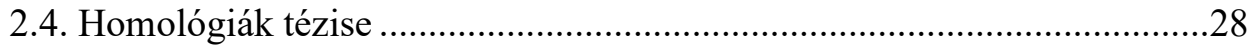

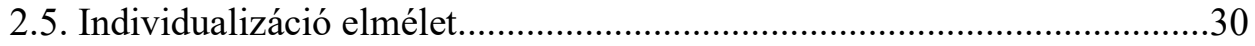

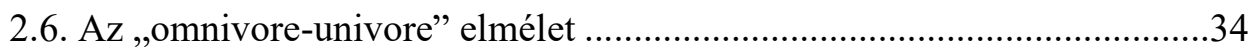

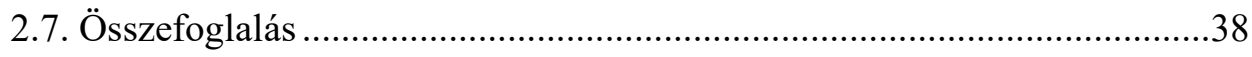

3. Ifjúságelméleti megközelítések..............................................................41

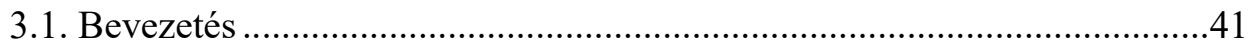

3.2. Elméleti diskurzusok az ifjúságkutatásban .............................................41

3.3. Kísérletek a magyarországi fiatalok társadalmi helyzetének leírására .....48

3.4. Kísérletek az erdélyi magyar fiatalok társadalmi helyzetének leírására...52

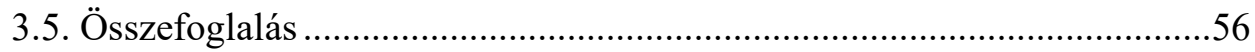

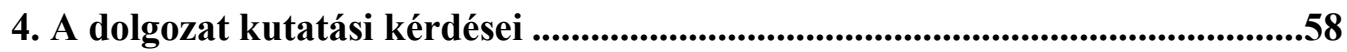

5. A dolgozatban használt adatok bemutatása ...............................................61

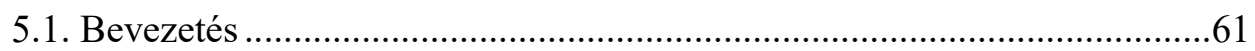

5.2. MOZAIK 2001. Magyar Fiatalok a Kárpát-medencében.........................61

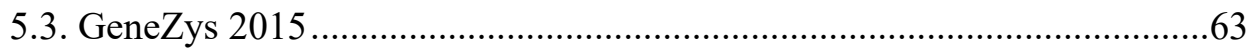

5.4. Magyar Ifjúság Kutatás 2016..............................................................64

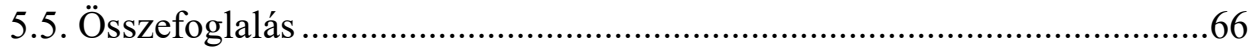

6. Az erdélyi magyar fiatalok szocio-demográfiai jellemzői 2001 és 2016

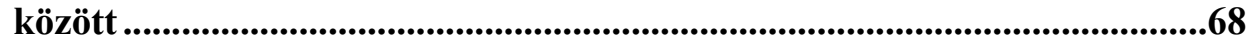

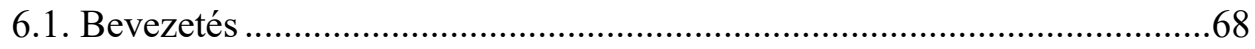

6.2. Demográfiai helyzetkép.................................................................6 68

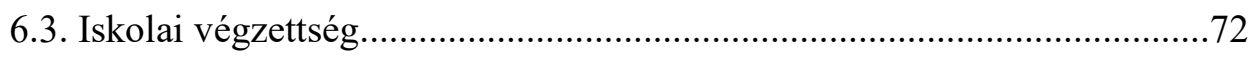

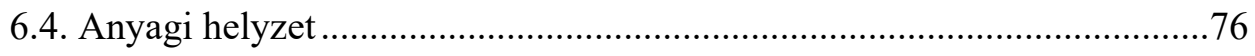

6.5. Foglalkozási rétegszerkezet 2001-2016 ................................................79

6.6. Kulturális-szabadidős fogyasztói mintázatok ...........................................85

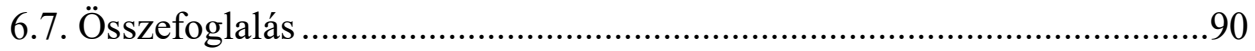




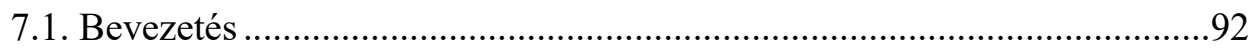

7.2. A státushelyzet társadalmi meghatározói. MOZAIK 2001 ......................92

7.3. A társadalmi státushelyzet meghatározásának modelljei: lineáris

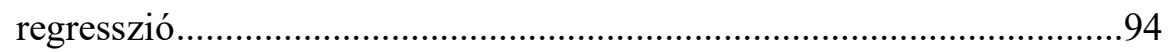

7.4. A státushelyzet társadalmi meghatározói. Magyar Ifjúság Kutatás 2016..96

7.5. A társadalmi státushelyzet meghatározásának modelljei: lineáris

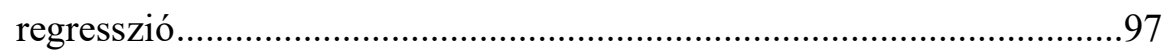

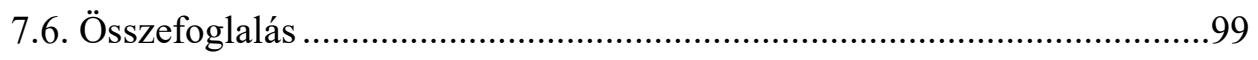

8. Kulturális szegmentáció az erdélyi magyar fiatalok körében.........................101

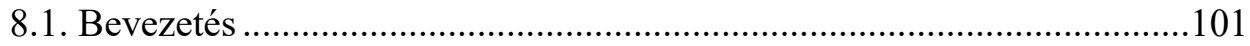

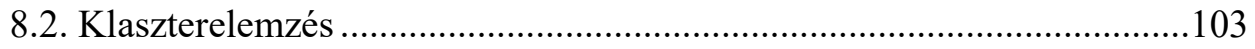

8.2.1. Hierarchikus klaszterelemzés. Klaszterek meghatározása Ward

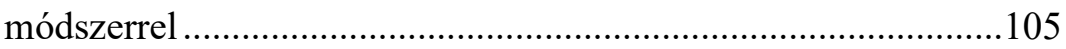

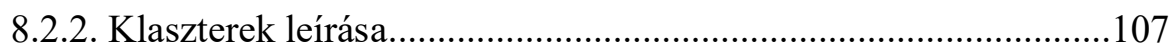

8.3. Kulturális szegmentációt befolyásoló tényezők. Regresszió-elemzések 111

8.3.1. Logisztikus regresszióelemzés ..................................................111

8.3.2. Multinomiális regresszióelemzés ...............................................115

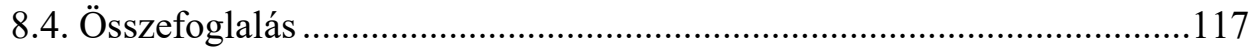

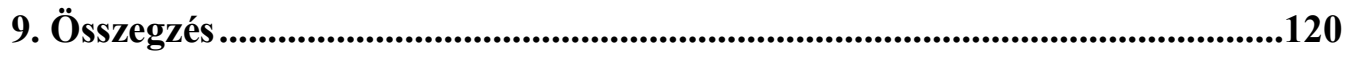

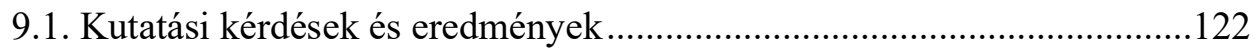

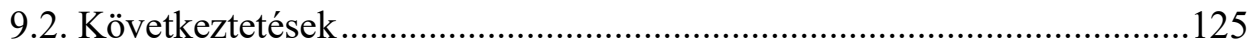

9.3. A kutatás korlátai és további kérdések ..................................................126

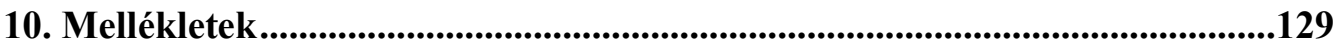

10.1. Szocio-demográfiai jellemzők 2001 és 2016 között. Táblázatok, ábrák

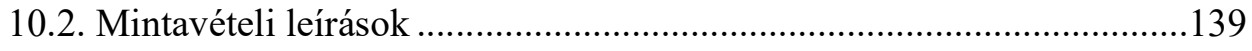

10.2.1. Mintavételi leírás MOZAIK 2001. Belső Erdély és Székelyföld

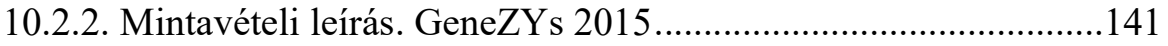

10.2.3. Mintavételi leírás. Magyar Ifjúság Kutatás 2016 .......................143

10.3. Szabadidős tevékenységekre, kulturális fogyasztásra vonatkozó

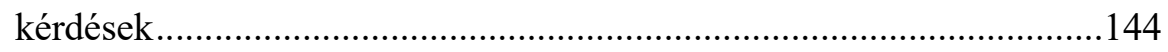

10.3.1. Mikor volt ön utoljára? MOZAIK 2001 .....................................144 
10.3.2. Milyen gyakran szoktad az alábbi tevékenységeket folytatni?

GeneZYs 2015

10.3.3. Milyen gyakran jár Ön a következő helyekre? Magyar Ifjúság

Kutatás 2016 146

10.4. Klaszterek meghatározása K-Means módszerrel. Fogyasztói csoportok leírása: 146

10.5. Kulturális szegmentációt befolyásoló tényezők. Regresszió-elemzések

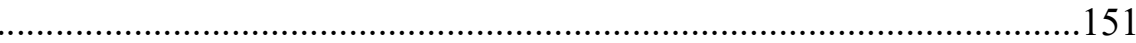

10.5.1. Logisztikus regresszióelemzés 151

10.5.2. Multinomiális regresszióelemzés 152

10.5.3. Ordinális regresszióelemzés 155

10.6. Hierarchikus klaszterelemzés, Ward módszer. Táblázatok, ábrák 157 


\section{Ábrajegyzék}

6.1. ábra: Az erdélyi magyar fiatalok számának alakulása 2002-2011 között.

Forrás: Népszámlálási adatok 2002-2011; Román Statisztikai Hivatal

(saját szerkesztés)

6.2. ábra: Az erdélyi magyar fiatalok számának alakulása 2002-2011 között faluváros bontásban. Forrás: Népszámlálási adatok 2002-2011; Román Statisztikai

Hivatal (saját szerkesztés) .70

6.3. ábra: Kulturális tevékenységek gyakorisága, 2015. Milyen gyakran szoktad az alábbi tevékenységeket folytatni? (saját szerkesztés) ......................................87

10.1 ábra: Fiatalok szubjektív jóléte 2001-2016 között (saját szerkesztés) ..............135

10.2. ábra: Erdélyi magyar fiatalok számának változása 2002-2015 között.

Forrás: Nemzeti Statisztikai Hivatal (saját szerkesztés)................................136

10.3. ábra: Fiatalok szabadidő-kulturális fogyasztása - 2001 (saját szerkesztés)....138

10.4. ábra: Fiatalok szabadidős-kulturális fogyasztása - 2016 (saját szerkesztés) ..138

10.5. ábra: Klaszterkönyök. Koefficiensek ábrázolása az összevonás lépései

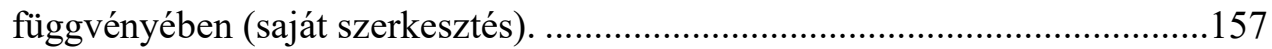

10.6. ábra: A Ward eljárás dendogramja (saját szerkesztés). 158 


\section{Táblázatjegyzék}

6.1. táblázat: Iskolai végzettség eloszlása különböző szocio-demográfiai kategóriákban. Mozaik 2001

6.2. táblázat: Iskolai végzettség eloszlása különböző szocio-demográfiai

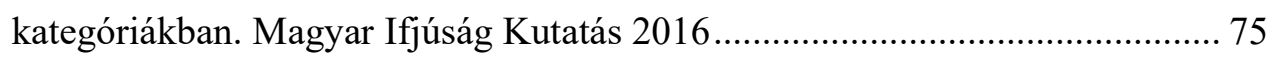

6.3. táblázat: Szubjektív jólét szocio-demográfiai ismérvek szerinti eloszlása (átlagok) 2001-2016.

6.4 táblázat: A foglalkozási rétegséma aggregálási szintjei. MOZAIK 2001. 81

6.5 táblázat: Foglalkozási státusok 2001-2016 82

6.6. táblázat: Foglalkozási státusok szocio-demográfiai ismérvek szerinti eloszlása. Mozaik 2001 83

6.7. táblázat: Foglalkozási státusok szocio-demográfiai ismérvek szerinti eloszlása. Magyar Ifjúság Kutatás 2016 84

6.8. táblázat: Kulturális tevékenységek gyakorisága, MOZAIK 2001. Mikor volt utoljára az alábbi helyeken?

6.9. táblázat: Kulturális tevékenységek gyakorisága, Ifjúság 2016. Milyen gyakran jár az alábbi helyekre? 89

7.1. táblázat: A főkomponens eredményei, a státusindex-komponens súlyértékei... 93

7.2. táblázat: A fiatalok státushelyzetét magyarázó lineáris regresszió együtthatói. Mozaik 2001 (OLS regressziós modell). 95

7.3. táblázat: A főkomponens eredményei, a státusindex-komponens súlyértékei... 97

7.4. táblázat: A fiatalok státushelyzetét magyarázó lineáris regresszió együtthatói. Ifjúság 2016 (OLS regressziós modell) .98

8.1. táblázat: Hierarchikus klaszterelemzés során az egyes klaszterek elemszáma 105

8.2. táblázat: Kulturális aktivitások gyakorisága az egyes fogyasztói szegmensekben $(\%)$ 107

8.3. táblázat: Társadalmi demográfiai csoportok kulturális klasztereken belüli aránya $(\%)$ 109

8.4. táblázat: Az egyes kulturális csoportokba való tartozást befolyásoló tényezők. Logisztikus regressziós modellek együtthatóinak exponenciális értékei Exp (b) 
8.5. táblázat: Az egyes kulturális csoportokba való tartozást befolyásoló tényezők. Multinominális regressziós modellek együtthatóinak exponenciális értékei Exp (b) 116

10.1. táblázat: Főbb szocio-demográfiai változók 2001 és 2016-ban 129

10.2. táblázat: Főbb szocio-demográfiai változók 2001 és 2015-ben 130

10.3. táblázat: Szubjektív jólét szocio-demográfiai ismérvek szerinti eloszlása. Mozaik 2001 131

10.4. táblázat: Szubjektív jólét szocio-demográfiai ismérvek szerinti eloszlása. Magyar Ifjúság 2016. 132

10.5. táblázat: A fiatalok munkaerőpiaci helyzete. MOZAIK 2001 133

10.6. táblázat: A fiatalok munkaerőpiaci helyzete. Magyar Ifjúság 2016 134

10.7. táblázat: Iskolai végzettség településtípus szerint. 134

10.8. táblázat: Kulturális fogyasztás. Hány könyvet olvasott? 134

10.9. táblázat: Kulturális fogyasztás: Kifejezetten turisztikai céllal utazott-e az elmúlt évben? 135

10.10. táblázat: Kulturális tevékenységeken való részvétel az Európai Unió tagországaiban. Az elmúlt egy hónapban legalább egyszer részt vett az alábbi tevékenységeken: $\%$

10.11. táblázat: Az alappopuláció megyék szerint - Forrás: 1992. évi népszámlálási adatok.

10.12. táblázat: A minta felbontva település-típusonként 140

10.13. táblázat: A mintába került települések. Székelyföld. Forrás: Bálint BlankaDemeter, 2001

10.14. táblázat: Az alappopuláció eloszlása nem, életkor, lakhely típusa és régió szerint. Forrás: Papp Z. et al. 2017.

10.15. táblázat: Az alappopuláció megyék szerint - Forrás: 2001. évi népszámlálási adatok. 143

10.16. táblázat: Kulturális aktivitások gyakorisága - fogyasztási szegmensek szerint $(\%)$ 147

10.17. táblázat: Társadalmi demográfiai csoportok kulturális klasztereken belüli aránya $(\%)$.

10.18. táblázat: Az egyes kulturális csoportokba való tartozást befolyásoló tényezők. Logisztikus regressziós modellek együtthatóinak exponenciális értékei Exp (b) 
10.19. táblázat: Az egyes kulturális csoportokba való tartozást befolyásoló tényezők. Multinominális regressziós modellek együtthatóinak exponenciális értékei Exp (b) 153

10.20. táblázat: Ordinális regresszió koefficiensei ............................................... 156

10.21. táblázat: Kulturális aktivitások gyakorisága - fogyasztási szegmensek szerint $(\%)$.

10.22. táblázat: Társadalmi demográfiai csoportok kulturális klasztereken belüli aránya (\%) 3 klaszteres megoldás Ward módszerrel.................................... 160

10.23. táblázat: Kulturális aktivitások gyakorisága - fogyasztási szegmensek szerint $(\%)$. 161

10.24. táblázat: Társadalmi demográfiai csoportok kulturális klasztereken belüli aránya (\%) 4 klaszteres megoldás Ward módszerrel. 162

10.25. táblázat: Kulturális aktivitások gyakorisága - fogyasztási szegmensek szerint $(\%)$. 163

10.26. táblázat: Társadalmi demográfiai csoportok kulturális klasztereken belüli aránya (\%) 5 klaszteres megoldás Ward módszerrel. 164 


\section{Köszönetnyilvánítás}

Mindenekelött köszönettel tartozom Bartus Tamásnak és Csata Zsombornak, hogy elvállalták a témavezetést, akik a hosszúra nyúló munkafolyamat során mindvégig mellettem álltak és segítették munkámat. Köszönöm nekik, hogy mindig számíthattam visszajelzéseikre, megértésükre és pozitív hozzáállásukra. A közös munka során rengeteget tanulhattam tőlük.

Hálás vagyok a Max Weber Társadalomkutatásért Alapítványnak, hogy kutatói hátteret biztosított, akkor amikor nagyon egyedül éreztem magam. Köszönöm Veres Valérnak az örökös biztatását és türelmét, hogy mindig számíthattam rá, ha valahol elakadtam.

Doktori munkám során a Sapientia Hungariae Alapítvány Collegium Talentum ösztöndíjasa voltam két évig. A program keretében nyújtott segítséget ezennel is köszönöm.

Köszönöm a tézistervem opponenseinek, Kmetty Zoltánnak és Papp Z. Attilának az alapos véleményezést és értékes észrevételeket, melyek szakmailag jobbá tették a dolgozatomat.

A szakmai segítségek mellett hálás vagyok családomnak és barátaimnak, hogy támogattak, lendületet adtak és türelmesen viselték a nehezebb napokat.

Köszönöm mindenkinek, aki hozzájárult egy bátorító szóval, hogy sikeresen befejezhessem munkámat.

Meggyőződésem, hogy témavezetőim, barátaim, családom útmutatásai és bátorítása nélkül ez a munka nem született volna meg. 


\section{Bevezetés}

Jelen dolgozat célja az erdélyi magyar fiatalok társadalmi struktúrában elfoglalt helyének meghatározása és bemutatása az elmúlt tizenöt-húsz év ifjúságkutatásainak az eredményei alapján. Vizsgáljuk a fiatalok társadalmi-gazdasági, munkaerőpiaci és iskolázottsági helyzetében bekövetkezett változásokat. A státuszhelyzetük változásának a tényezőit kutatjuk: melyek hatnak a fiatalok státushelyzetére, a kulturális fogyasztásukra. Vizsgálatunk fontos kérdése a státuszhelyzet és az ezt befolyásoló tényezők változása 2001 és 2016 közötti periódusban.

A társadalmi struktúrakutatás kitüntetett helyet foglal el a társadalomkutatásokban, ezért talán ez az egyik legtöbb vitát kiváltó terület. A klasszikus elméletek nagyobb társadalmi csoportokba sorolják az egyéneket, ezeket osztályoknak nevezik. Ezen elméletek szerint a társadalmi különbségek legfőképpen gazdasági tényezőkkel magyarázhatóak és az osztályokat elkülönítő választóvonalat a tőkével és termelőeszközökkel bírók, illetve a munkaerejüket eladók között húzzák meg. A klasszikus elméletek mellett egyre több kutatót foglalkoztat a társadalmi tagozódás dilemmája, az osztálykategóriák érvényessége. A napjaink struktúra-kutatói szerint ugyanis az osztályozást újra kell gondolni. Az újragondolás szükségességének fő mozgatórugója a globalizáció - melyet most a megnövekedett földrajzi mobilitás és a posztmodernitás kontextusában értelmezünk - mely sok faktort átformál és melynek következtében ezek a faktorok - az osztálystruktúrával kiegészítve sem - adnak kielégítő magyarázatot a társadalmi jelenségekre. Az utóbbi évtizedekben számos elmélet született azzal kapcsolatban, hogy a társadalmak hagyományos osztályalapú tagolódását (Ferge 1969; Erikson-Goldthorpe-Portocarero 1988; Huszár 2012) felváltotta a fogyasztásalapú tagolódás és az egyének társadalmi helyét - szociális helyzetét - egyre inkább a fogyasztás jelöli ki (Clark-Lipset 1991; Hradil 1995; Pakulski-Waters 1996; Beck 1999; Schulze 2000; Csite-Kovács-Kristóf 2006). Azt látnunk kell, hogy ez a fogyasztásalapú megközelítés problematikus; az újdonságértékét megkérdőjelezi a 
fogyasztás mérőszámainak a korrelációja az osztályhelyzet változóival: amennyiben adott státuszú egyének vásárolnak a adott terméket vagy fogyasztanak egy adott kulturális terméket és a fogyasztás teljesen osztályfüggő, akkor a fogyasztásalapú megközelítés hierarchiája és a klasszikus struktúrák között nem lesz különbség.

Azt mondhatjuk tehát, hogy egy első eldöntendő kérdés az általunk vizsgált a fiatalok szegmentációjának alakulásában a tényezők kiválasztása. Lehetőségünk van a „kemény”, hagyományos mérőszámok - ezek alatt a foglalkozást vagy a kissé kibővített foglalkozási osztálykoncepciót, az iskolai végzettséget és a jövedelmet értjük használatára, ezeket esetleg kiegészítve a „szoft” tényezők, mint az életmód, a fogyasztás, nem, életkor figyelembevételére az elemzésünk során.

Bár a társadalmi rétegződés vizsgálatának és módszertanának több évtizedes hagyománya van, mégis ez egy nehezen megragadható és leírható folyamat. Nincs egyetértés abban, hogy melyek a relevánsnak tekinthető változók, különösen akkor, ha a fiatalok társadalomban elfoglalt helyét akarjuk megérteni. A romániai magyarság osztály- és rétegszerkezetére vonatkozóan, az ezredforduló után is hiányoznak az átfogó kutatások: kevés a célzottan a fiatalok rétegződésére vonatkozó elemzés, a doktori tézis ezt a hiányosságot kívánja pótolni.

A fiatal korosztály rétegszerkezetének leírása nehéz feladat, mert a fiatalok még egy úgynevezett útkereső állapotban vannak, nem rendelkezik mindenki foglalkozási pozícióval, ugyanakkor a fiatalok egy része még a szülőkkel él, másik része családot alapított, ezért még nagyobb a változatosság a különböző rétegszempontok szórásában. Ez egy lényeges módszertani kérdést vet, nevezetesen azt, hogy szabad-e elemzésben a fent említett két réteget egy csoportnak tekinteni. Másképp fogalmazva, az a kérdés, hogy a fiatal státusát vagy az örökölt státust vegyük figyelembe az elemzés során ${ }^{1}$.

A nehézségek ellenére vannak próbálkozások a fiatalok társadalmi rétegszerkezetének leírására, amelyekre a szakirodalmi összefoglalónkban részletesen ki is térünk. Mi is kihívásként tekintünk erre a feladatra, egyrészt azért, mert az utóbbi idők elméletei azt állítják, hogy a posztindusztriális korszakban a fiatalság növekvő

\footnotetext{
${ }^{1}$ Ezért a dolgozatunkban a tanulókat és a dolgozókat külön vontuk be az elemzésbe.
} 
önállóságot vív ki magának, és ez a csoport fogyasztásában, értékrendjében valamint érdekei artikulálásában is egyre önállóbb (Ercsei-Kiss-Szabó 2011; Gábor-Veres 2011). Viszonylag egyetértés van abban a tekintetben is, hogy ifjúságon nemcsak egy beazonosított korosztályt kell érteni, hanem egy sajátos jellemzőkkel és igényekkel rendelkező társadalmi csoportot (Papp Z. 2017).

A leggyakrabban használt rétegképző tényező a rétegződés leírására a foglalkozási pozíció. A társadalmi rétegződés vizsgálatának hagyományos irányzata a foglalkozási osztályszerkezet szerinti megközelítést, elsősorban valamilyen foglalkozási klasszifikációt, illetve munkaerőpiaci ismérveket vesz alapul, és kategoriális különbségeket állapít meg a társadalmon belül. A rendszerváltást követően még sokáig főleg a közép-kelet-európai országokban - a hagyományos strukturáló mechanizmusok differenciálják a társadalmat, viszont ma már megjelennek az új struktúraképző elemek, mint az életmód és a fogyasztás is, és ezek a fiatal korosztályt erőteljesebben érintik.

Egyik fő kutatási kérdésünk, hogy: ha le akarjuk írni az erdélyi magyar fiatalok társadalmi térben való tagolódását, akkor erre elégséges-e a hagyományos (osztályalapú) paradigma, vagy a fogyasztásalapú tagolódást is figyelembe kellene venni. Elemzésünk során keressük a fiatalok társadalmi tagolódását legjobban leíró rétegződéselméleti megközelítést. Másik fontos kérdés azon tényezők azonosítása, melyek mentén a fiatalok társadalmi rétegződése magyarázható.

A dolgozatban arra törekszünk, hogy egy többdimenziós rétegszerkezeti modellel írjuk le a fiatalok szegmentációját, a régi és az új struktúraképző elemek együttes alkalmazásával. Tehát a foglalkozás és az anyagi helyzet dimenzióit, valamint a szabadidős és kulturális fogyasztás elemeit összehangolva elemezzük a mai fiatalokat, valamint a századforduló után végbement társadalmi tagozódásukban megfigyelt változásokat. 


\subsection{A dolgozat struktúrája}

A doktori tézis tíz szerkezeti egységből áll, a mellékleteket is beleértve. A bevezetô rész után áttekintjük a releváns szakirodalmat, hangsúlyt fektetve az ezredfordulót követően napvilágot látott fiatalok társadalmi rétegszerkezetének leírására, mind a nemzetközi, mind a román, mind pedig a magyarországi, illetve az erdélyi magyar szakirodalomban. Ezt követően bemutatjuk a kutatási kérdéseinket (4.fejezet), illetve a használt adatbázisokat (5. fejezet).

Elemzésünk három részre tagolódik, az első részben (6. fejezet) a főbb szociodemográfiai változók mentén a 15-29 év közötti fiatal populáció leírását adjuk, egyrészt a népszámlálási adatok, másrészt két nagyobb kérdőíves ifjúságkutatás eredményei alapján; ezekre 2001-ben és 2016-ban került sor. A hagyományos foglalkozásszerkezeti modell segítségével megvizsgáljuk a fiatalok foglalkozási struktúrájának időbeni változását.

A második részben (7. fejezet) a státushelyzet és a különböző szocio-demográfiai jellemzők közötti összefüggéseket vizsgáljuk. A fiatalok rétegződésének leírására egy összetett mutatót hoztunk létre - státusindexet szerkesztettünk - amely a társadalom vertikális differenciálódásának mérésére alkalmas. A fejezethez tartozó első kutatási kérdésünk az, hogy hogyan magyarázzák a státushelyzetet a különböző szociodemográfiai jellemzők (nem, életkor, településtípus)? Második kutatási kérdésünk, a származás hatása (apa iskolai végzettsége, foglalkozása) a fiatalok státusára.

A harmadik részben (8. fejezet) a kulturális fogyasztásban mutatkozó társadalmi különbségeket vizsgáljuk. A következő kérdésekre keressük a választ: (1) Milyen kulturális fogyasztásbeli jellegzetességek alapján különülnek el az erdélyi magyar fiatalok? (2) Milyen tényezők befolyásolják a kulturális fogyasztási szokásaikat? (3) Mennyire érvényes körükben az a megközelítés, mely szerint a „kulturális mindenevőség” felbukkanása feloszlatja az osztályalapú megkülönböztetést a kulturális fogyasztás tekintetében?

Az utolsó (9. fejezetben) fejezetben a kutatási kérdések és elemzések fényében összegezzük következtetéseinket, kitérve a kutatás korlátaira és további elemzési lehetőségekre. 


\section{Társadalmi rétegződés és osztályszerkezet}

\subsection{Bevezetés}

Áttekintjük a társadalmi rétegződés fő paradigmatikus megközelítéseit, hangsúlyt fektetve a fiatalok helyzetével, illetve a kulturális fogyasztással kapcsolatos elméletekre.

A társadalmi szerkezet vizsgálatának nincs egységes elméleti kerete és módszertana. A rétegződés kutatására kétféle megközelítés létezik, az egyik az osztályszerkezeti megközelítés, mely szerint a foglalkozás, a munkaerőpiaci helyzet mutatja meg az egyén társadalomban elfoglalt helyét, a másik, a rétegződési megközelítés fogyasztási mintázatokkal írja le a társadalmat, ezek az életstílus- és a miliőkutatások.

\subsection{Foglalkozási osztályszerkezet}

Az osztály fogalmát a 18. század végétől használják a társadalom szerkezetének megértéséhez. A foglalkozási osztályszerkezet megközelítése a társadalmi rétegződés vizsgálatának önálló irányzatát képezi, melynek egyik fő jellemzője, hogy kategoriális különbségeket állapít meg a társadalmon belül. A szocialista társadalmak osztályszerkezetének ortodox marxista megközelítése a két osztály (munkásság és parasztság) és egy réteg (értelmiség) modellen alapult (Róbert, 1999).

Az első tanulmányok, amelyek a magyarországi társadalomszerkezet elméleti problémáját egészében vizsgálják, Hegedüs András (1966) és Ferge Zsuzsa (1969) nevéhez füződnek. Mindketten az egyén munkamegosztásban elfoglalt helyének szerepét hangsúlyozták a társadalmi struktúra vizsgálatában. Hegedűs (1966) nem tartotta megfelelőnek a kétosztályos modellt a szocialista társadalom ezen időszakára, de ugyanakkor nem adott alternatívát a kétosztályos modellel szemben (Hegedűs 1966). 
Ferge a '60-as évek magyar társadalmának rétegződését elsősorban a munkamegosztás alapján írja le (Ferge 1969). Munkássága során használja az „osztály” fogalmat de a későbbiekben úgy fogalmaz, hogy igen nagy bajban van az „osztály” kategóriájával (Ferge 2012: 123), érvényessége és tartalma annyit változott, hogy: „inkább egy kényelmesebb elméleti keretet választott, ez korábban a munkajelleg csoport volt, jelenleg nincs neve az új struktúra-modelljének". Véleménye szerint sokkal világosabban kellene meghatározni, hogy mit tekintsünk társadalmi osztálynak, mielőtt ezt a címkét társítanánk a nagy és sokszínű csoportokhoz. (Ferge 2012)

A weberi felfogás szerint három vonatkozásban differenciálódnak a társadalmon belüli helyzetek (osztályok, rendek és pártok), de hangsúlyosan az osztályhelyzetet és a rendi helyzetet különbözteti meg egymástól. Az osztályhelyzetek tovább differenciálódnak, egyrészt a tulajdon tárgya, másrészt a teljesítmények jellege szerint. Az osztályhelyzettől eltérő fogalomként határozta meg a rendi helyzet fogalmát, amelynek három ismertetőjegyét nevezte meg: az egyének (1) sajátos megbecsültsége, (2) életmódja és (3) pozitív vagy negatív privilégiumai (Weber 1987). A weberi gondolkodásban már érezhetően megjelenik a társadalmi szerkezet sokdimenzióságának a feltételezése.

A kilencvenes évek elejétől a TARKI égisze alatt elsősorban neo-weberiánus rétegződési és életstílus alapú elemzések születtek (Fábián-Róbert-Szívós 1998; Fábián-Kolosi-Róbert 2000; Kolosi-Róbert 2004; Fábián 2015). Az elemzések abból indulnak ki, hogy a társadalmi jólét anyagi, materiális dimenzióját három fő tényező határozza meg: a jövedelem, a fogyasztás és a vagyoni javak eloszlása. Úgy vélik, hogy a mai szolgáltató-információs társadalomban ezek a társadalmi rétegződés legfontosabb összetevői, mert a fogyasztás révén nyilvánosan is kifejeződnek a hierarchikus és a nem hierarchikus jellegű társadalmi különbségek. Tehát a magyar társadalom fố csoportjait anyagi és kulturális fogyasztás szempontjából különítik el.

Kolosi (2000) a társadalmi egyenlőtlenség rendszerét úgy értelmezi, mint egy többdimenziós teret, a kétezres évek elején hat egyenlőtlenségi dimenziót - mint jelentős státusképző és státusmeghatározó faktort - vesz figyelembe az elemzés során. A strukturális egyenlőtlenségek csoportjába sorolják a foglalkozás, iskolai végzettség, jövedelem és hatalmi-érdekérvényesítési viszonyok mentén való hierarchikus 
elrendeződést, míg az életkörülmények alapján meghatározott egyenlötlenségek esetében az anyagi-materiális életstílus és a kulturális életstílus elkülönülését tartja fontos tényezőnek (Kolosi 2000).

Wright, megőrizve a marxi hagyomány osztálystruktúráját, a társadalmak szerkezetét kizsákmányolási viszonyok révén ábrázolja. Neomarxista osztályelmélete szerint az osztályhelyzetnek három összetevője van: a tulajdonviszonyokban, a szervezeti alá- és fölérendeltségi viszonyokban elfoglalt helyzet és a szakképzettség. (Wright $1985,1997)$

A szociológiai kutatásokban a foglalkozások pozícióját a stratifikációs rendszerben három módon mérik: presztízs-besorolásokkal, származtatott osztálykategóriákkal, illetve társadalmi-gazdasági státuspontokkal (Ganzeboom-De Graaf-Treiman 1992).

Az egyik legfontosabb foglalkozási osztályszerkezeti modell, az EGP neo-weberiánus osztályséma, Erikson, Goldhorpe és Portocarero² nevéhez kapcsolódik. A modellben legfontosabb választóvonalaként különbséget tesznek a foglalkoztatók, az önfoglalkoztatók, illetve az alkalmazottak csoportjai között. A modell egy másik fontos aspektust is figyelembe vesz, az alkalmazottak kategóriáját, és ezt osztja kisebb csoportokra, a munkavállaló és a munkaadó közti szerződéses viszonyt figyelembe véve. Hét osztályt határoznak meg az egyén foglalkoztatási pozíciójának megfelelően (Erikson-Goldthorpe-Portocarero 1988).

Egy másik hasonló modell az Európai osztálymodell (ESeC), egy új társadalmigazdasági osztályozási rendszer, amelyet az európai országok vizsgálatára dolgoztak ki. Elsősorban a EGP-sémát veszi alapul, a megkülönböztetés szintén a foglalkoztatók, az önfoglalkoztatók, illetve az alkalmazottak csoportjai mentén történik. Részben más osztálykategóriákat határoznak meg, eltérő módon sorolja be a foglalkozásokat (Huszár 2013a).

Az újabb rétegződés szakirodalomban felvetődik, hogy a 21. századi posztindusztriális társadalomban mennyire alkalmasak a hagyományos foglalkozás alapú

${ }^{2}$ Az osztályséma részletes leírásához, illetve logikai felépítéséhez lásd Erikson és Goldthorpe (1996), illetve Erikson, Goldthorpe és Portocarero (1998) munkájában található összefoglaló ábrákat. Illetve Huszár (2013) 
megközelítések. Mind a nemzetközi, mind a magyarországi szakirodalomban egyre gyakrabban kezdtek olyan érveket felsorakoztatni, amelyek kétségbe vonják az osztályokon alapuló elemzést, úgy vélik, hogy a klasszikus osztályelméletek egykoron alkalmasak voltak a társadalmi egyenlőtlenségek vizsgálatához, és megfelelő fogalmi keretet biztosítottak a társadalom struktúrájának leírásához, de sokak szerint mára már elvesztették relevanciájukat. Vannak, akik teljesen elvetik az osztály fogalmát, és a társadalom hierarchikus rendjét kétségbe vonják (Clark-Lipset 1991; Hradil 1995; Pakulski-Waters 1996; Beck 2004), mások pedig az osztálykoncepciók újragondolására hívják fel a figyelmet (Chan-Goldthorpe 2007a; Huszár 2012; Savage et al. 2013; Crompton-Scott 2014; Róbert 2015). Különösen a német szociológiában tartják vitatott, politikai konnotációkkal terhelt fogalomnak (Berger 2008), szemben a brit kutatókkal, akik szerint a foglalkoztatási besorolások hasznos társadalmi mutatók az egyenlőtlenségek vizsgálatában, ugyanakkor szükségesnek tartják az osztályelemzés újraértelmezését.

Treiman a rendszerváltás kontextusában ma is gyakran idézett modernizációs tézise szerint az oktatás elterjedtsége, a tömegkommunikáció, a fokozott urbanizációs folyamatok és a földrajzi mobilitás a merev osztályszerkezet lebontásának irányába hatnak. Eredményei szerint az iparosodottabb országokban az iskolázottságnak a foglalkozásra gyakorolt hatása erősebb, és az apa foglalkozásának hatása gyengébb. (Treiman 1988)

Az 1990-es évek elején Esping-Andersen is csatlakozik az osztályok eltünéséről szóló vitához. Nem ért egyet azzal a nézettel, mely szerint az osztály fogalma alkalmatlan lenne a társadalmi egyenlőtlenségek leírására, és a posztindusztriális sajátosságokat figyelembe véve dolgozza ki modelljét. Treimanhoz hasonlóan lényeges tényezőként emeli ki az oktatási expanziót, illetve a kétkeresős családmodell kialakulását, amely közvetlenül befolyásolja a gazdaságilag aktív népesség kiterjedését és annak jellemzőit. A foglalkozásokat horizontálisan, ágazati hovatartozásuk szerint különíti el (Esping-Andersen 1993).

Crompton is (1993) azt állítja, hogy az osztály a rétegződés egy még mindig fontos aspektusa a mai modern társadalmakban. Úgy véli, hogy az osztályelemzőknek el kell fogadniuk azt a korlátot, hogy a foglalkoztatási aggregátum alkalmazásával 
nem lehet minden osztályalapú problémát feltárni. Ez azonban nem jelenti azt, hogy a megközelítést el kell hagyni, inkább a korlátait kell felismerni. Az „osztály halálával” (Pakulski-Waters 1996) kapcsolatos viták inkább a társadalmi változásokra összpontosítanak, amelyek valóban hatással vannak az egyéni és csoportos identitásokra, de ez nem azt jelenti, hogy a foglalkoztatási besorolások nem hasznos társadalmi mutatók (Crompton 2008; Crompton-Scott 2014).

Huszár is az osztályelemzés megújítása mellett érvel és úgy véli, hogy míg a foglalkozási presztízsskálák vagy a komplexebb társadalmi-gazdasági mutatók a tagolódás graduális-hierarchikus jellegére fókuszálnak, addig az osztálymodellek különböző státuszpontszámok alapján mérik, hogy valakinek a társadalmi állása (menynyivel) magasabb vagy alacsonyabb. Tehát az osztálymodellek a mennyiségi különbségek helyett inkább minőségi különbségeket mérnek a társadalom tagjai között $(\mathrm{Hu}-$ szár 2012).

Róbert is szorgalmazza azt a nézetet, hogy a foglalkozás többdimenziós jelenségként is felfogható (Róbert 1997), amelynek elkülöníthető egy materiális és egy kulturális metszete. Ezt Bourdieu (1984) elméletére vezeti vissza, amely megkülönbözteti a kulturális és anyagi tőkét, illetve a kulturális és anyagi életstílust. Szerinte téves az az értelmezés, hogy a foglalkozásalapú osztályozás egydimenziós, mert a foglalkozás egyrészt következményjellegü, ha az iskolai végzettségen múlik, hogy valaki milyen munkát talál, másrészt magyarázó jellegü, amennyiben hatása van a jövedelemre. Igaz, később azt is megjegyzi, hogy a foglalkozási-osztályszerkezet direkt módon sem végzettséget, sem más tényezőt nem vesz figyelembe (Róbert 2015). Ugyanakkor Ferge is jelezte írásaiban - annak ellenére, hogy a kapitalizmusban is igaz, hogy a gazdasági érdekek a különbözö érdekcsatornákon keresztül áthatják a társadalmi viszonyok rendszerét - hogy a viszonyok bonyolultsága megköveteli, hogy a társadalmi helyzetek vizsgálatánál mindig sokrétü elemzésre van szükség (Ferge 1969).

Huszár szerint az osztályelméleteket leginkább az különbözteti meg az életstílus- és milliőkutatásoktól, hogy az egyének társadalmi helyét továbbra is strukturális kényszerek határozzák meg, és valamely elmélet segítségével jutnak el az különböző kategóriákhoz (Huszár 2013b). Véleménye szerint az életkörülmények alakulása 
szempontjából nagy tere van a strukturális magyarázatoknak, és egyre kisebb az individuális jellemzőknek (Huszár 2019). Kutatási eredményei szerint jelenleg a magyar társadalom egyre határozottabban egy osztálytársadalom képét mutatja. Két markáns tendencia rajzolódik ki, amelyek közül az egyik az osztályszerkezet különböző szintjein elhelyezkedők életkörülményeinek gyors ütemü javulását jelzi, a másik, ezzel párhuzamos folyamat szerint viszont a társadalomszerkezet polarizációja tovább folytatódott. Hasonlóan vélekedik Éber Márk Áron, amikor a magyar társadalom szerkezetét egy olyan csepphez hasonlítja, ami alakját tekintve az elmúlt években megnyúlt, hosszú vékony hegye a felső-uralkodó tőkésosztályok helyzetét mutatja, szélesebb alsó része pedig a munkásosztályt (Éber 2020). Ugyanakkor amellett érvel, hogy Huszár Ákos az elosztási egyenlőtlenségeket vizsgálva valójában a rétegződés eszközeit használja, nem pedig az osztályszerkezetét. Véleménye szerint nem beszélhetünk osztályelemzésről termelési viszonyok, piaci helyzet és tőkeviszonyok elemzése nélkül (Éber 2015). Egyetért azzal, hogy az osztályszerkezet elemzés nem idejétmúlt, azaz továbbra is vannak osztályok, ezt viszont csak történetileg formálódó viszonyok vizsgálatával lehet meghatározni. Bourdieu is csak „papíron létező osztályokról” beszél, nem valós, aktuálisan létező osztályról, vagyis nem kézzelfogható csoportokról, legfeljebb „valószínűségi osztályokról” (Bourdieu 2013).

Mi is egyetértünk azzal az állítással, miszerint az osztályok nem „megszemélyesíthető aktorok”, hanem ,gazdasági és társadalmi viszonyok konstellációi” (Éber 2015: 122), illetve hogy osztályszerkezeti elemzés a viszonyok elemzésével megvalósítható. Úgy gondoljuk, hogy az alábbi idézet rendet teremt abban az elméleti káoszban, ami az osztály- és rétegződéselméletek körül zajlik: „Ha az osztályelemzést a termelési viszonyok, a gazdasági-társadalmi szerkezetek és folyamatok dinamikus elemzéseként fogjuk fel, akkor elsősorban nem a népességből vett reprezentatív minta megfigyelt elemeinek osztályozásában kell gondolkodnunk. Akkor elsősorban osztálypolitikákra, érdekkoalíciókra, formálódó osztályszövetségekre és konfliktusokra, azaz az érdekkoalíciók történeti alakulására és a különféle ágensek változó viszonyaira kell szegeznünk a figyelmünket.” (Éber 2015:136) 


\section{3. „Új osztálymodell”}

Nagy-Britanniában 2011 és 2013 között zajlott egy nagy-volumenű online társadalomtudományi kutatás (Great British Class Survey). A kutatás első fordulója ${ }^{3}$ 2011-ben, a második forduló ${ }^{4}$ 2013-ban zárult. A második forduló előtt a BBC Lab UK egy „osztálykalkulátor” segítségével mozgósította az egyéneket. Az osztálykalkulátor egy öt kérdésből álló, önbesorolás-alapú online kérdőív, ahol az egyének tudathatták hovatartozásukat (Devine-Snee 2015).

A GBCS kutatás nagy visszhangot váltott ki a kutatók között, és úgy módszertani, mind elméleti tekintetben sok kritika érte. Egy fontos kritika pont a felmérés során használt „osztálykalkulátor”, melyet túlzottan leegyszerüsítettnek - egyszerüsítőnek - véltek (Mills 2015). Egy másik - módszertani - éles kritika a kutatás fele az, hogy az „online” adatok mellől hiányzanak az „offline” „kontrollcsoportos” vizsgálatok. Ezek nélkül a kutatás torzít, ugyanis a kérdésekre a fiatalabb és képzettebb egyének válaszoltak túlnyomórészt. Egy további kritika, hogy a társadalmi szerkezet bemutatásakor a GBCS kutatói a hivatalos brit statisztikai foglalkozási osztályozást alkalmazták, azaz nem új osztálytérképet rajzoltak meg, hanem inkább az „elitek” vizsgálatával foglalkoztak (Mills 2015).

A GBCS kutatás hozadéka ${ }^{5}$ az osztályelemzés megújításának szorgalmazása, ahol az új osztályok meghatározása során a kulturális fogyasztáson van nagyobb hangsúly. Ezzel párhuzamosan ezen tanulmányok az EGP séma és a neo-marxista osztálymodellek több hiányosságára is felhívták a figyelmet. A GBCS modell elsősorban abban különbözik az EGP sémától, hogy egy induktív, nem deduktív osztályséma és célja, hogy jobban megvilágítsa a kulturális és társadalmi határokat Nagy-Britanniában: melyek a társadalmi osztályok új határai. Annak ellenére, hogy a GBCS elemzése kvantitatív adatokra támaszkodik, ők is úgy vélik, hogy kvalitatív kutatással egy

\footnotetext{
${ }^{3}$ A BBC kezdeményezésére készült, 161400 online válaszadóval, ami mellett azonos mintán egy országosan reprezentatív felmérést is végeztek, 1026 fös mintán.

${ }^{4}$ A második forduló után 2013 júliusában további 183.119 kitöltött kérdőív érkezett be.

${ }^{5}$ A GBCS kutatók: Mike Savage (London School of Economics, UK), Fiona Devine (University of Manchester, UK), Niall Cunningham (University of Manchester, UK), Mark Taylor (University of York, UK), Yaojun Li (University of Manchester, UK), Johs. Hjellbrekke (Universitetet i Bergen, Norway), Brigitte Le Roux (Université Paris Descartes, France), Sam Friedman (City University London, UK), Andrew Miles (University of Manchester, UK).
} 
részletesebb, többdimenziós megközelítést is el tudnának érni. Bourdieu-re hivatkozva, a hagyományos egyenlőtlenségi dimenziók és a (kulturális) fogyasztás ötvözésével többdimenziós, a kulturális tőkefajtákat és a társadalmi kapcsolatokat is magukba foglaló osztálymodell felállítását javasolják. Azt tették vizsgálat tárgyává, hogy a gazdasági, társadalmi és kulturális tőke birtoklása miként befolyásolja a társadalmi tagozódást (Savage et al. 2013).

Az elemzés során hét osztályt ${ }^{6}$ azonosítottak, azonban e hét osztály közül csak kettő feleltethető meg a „közép-” és a „munkásosztálynak” a hagyományos szociológiai modellekben. A hét osztály legfelső szintje az „elit" (6\%), akik a legtöbb társadalmi, kulturális és gazdasági tőkével rendelkeznek. Az ezt követő csoport az úgynevezett „uralkodó középosztály", amely mind gazdasági, társadalmi, mind pedig kulturális tőke-tulajdonlás szempontjából szintén magas pontszámot mutat fel. A GBCS szerint ez az osztály megtestesíti a Goldthorpe által azonosított „,szolgáltatási osztályt” a jellemzőket illetően. Goldthorpe szerint ez az egyetlen nagyobb osztály, mely a népesség egynegyedét teszi ki. Ez azt jelenti, hogy mindkét értelmezés szerint a stabil középosztály valóban egy nagy csoport a brit társadalomban. Az ezt követö - harmadik - csoport a „technikai középosztálynak" (6\%). Ez egy kisebb, sajátosabb új osztálycsoport, magas gazdasági tőkével, viszont kevesebb társadalmi- és kulturális tőkével ellátva. A negyedik csoport az „új befolyásos munkavállalók" csoportja (15\%), mely egy fiatal, társadalmilag és kulturálisan aktív csoport, közepes mennyiségü gazdasági tőkével. Az ötödik csoport a „hagyományos munkásosztály” (14\%), melynek esetében a vizsgált tőkefajták mindegyike alacsony. A hatodik csoport a „feltörekvő szolgáltató munkavállalók", mely egy új, zömmel városi fiatalok, akik viszonylag szegények és moderált társadalmi és kulturális tőkével rendelkeznek. Ők a legfiatalabb csoport, átlagéletkoruk 34 év. És végül a hetedik csoport a ,prekariátusok”, ők a népesség 15\%-át teszik ki. A legalacsonyabb gazdasági, társadalmi és kulturális tőkével rendelkező csoport, közülük 30 egyénből csupán egynek van felsőfokú iskolai végzettsége.

${ }^{6}$ Ezek nevei angolul: elite, estabslihed middle class, technical middle class, new affluent workers, traditional working class, emergent service workers, precariat 
A GBCS kutatói szerint ez az új osztálykonstrukció felfedi a társadalmi egyenlőtlenségek polarizálódását, valamint magyarázatot ad az osztályok fragmentálódásának növekedésére is. Értelmezésük szerint a létrejött hét osztály tulajdonképp a hagyományos „közép-” és „,munkás-” osztályhatárok elmosódásának és töredezettségének a bizonyítékai (Savage et al. 2013). Az új osztálykonstrukció szerint az osztályok közötti határokat nem a társadalmi szerkezet középső szintjeinél célszerü meghúzni, hanem a legfelső régiókban. A konstrukció hiányossága azonban az, hogy a társadalmi osztálystruktúra felső részében korlátozott az osztálydinamika feltárása (Savage et al. 2013; Savage 2015).

Mills igen erős kritikát fogalmaz meg a GBCS eredményeivel szemben. Szerinte a kutatás mind elméletileg mind pedig módszertanilag egy kudarc. Szerint a munka egy „Bourdieu ihlette elmélet nélküli adatbányászat” (Mills 2015). Bradly (Bradley 2014) elismeri, hogy a GBCS felmérés fontos hozzájárulás az osztály újjáéledt szociológiai vizsgálataihoz, de néhány hiányosságot ő is kiemel: az osztály megközelítése graduális, nem relációs, a modellbe bevont kulturális tőke indikátorai rendkívül szelektívek, ami torzítja az eredményeket és negatív képet fest a munkásosztály kulturális fogyasztásáról, illetve hogy a látens osztályelemzéssel kapott modell nem koherens, inkább csoportokat képez. Dorling szerint a GBCS kutatás erőssége, hogy nyilvános vitát indított az osztály meghatározásáról és a társadalmi osztály relevanciájáról. A társadalmi osztályok változnak, mivel az emberek gyakrabban mozognak a világon és a különböző osztályrendszerek között, különböző pozíciókat töltenek be különböző helyeken, amelyek megváltoztatják az osztály jelentését. A növekvő gazdasági bizonytalanság csökkenti a bevett bizonyosságokat. A cikk legfontosabb hozadéka, hogy felhívja a figyelmet arra, hogy szükséges foglalkozni az osztályfogalommal, szükség van a társadalmi viszonyrendszerek tisztább látására (Dorling 2014).

Savage és társai modelljét Magyarországon is sok kritika érte. Egy fontos megállapítás, hogy a GBCS modell nem hozott gyökeresen újat; a létrejött osztálymodell nem többdimenziós, hanem hierarchikus; az osztályok azonosítása és megnevezése a foglalkozásviszonyok alapján történik. A kulturális tőke, a fogyasztás és a kapcsolatok ugyan megjelennek az osztályok leírásánál, de csupán mint a foglalkozási és tulajdoni osztály-meghatározók kiegészítői (Gerő-Kovách 2015). 
A felsorolt hiányosságok ellenére a GBCS modell erőssége, hogy ez a hétosztályú modell felismeri a - jelen esetben - brit társadalomban tapasztalható társadalmi polarizációt, illetve a középső rétegek - a hagyományos középosztály - széttagoltságát. Ez a felismerés hozzájárulhat egy korszerü társadalmi struktúra sokoldalú modelljének a kidolgozásához, ugyanis napjainkban a népesség nagyrésze klasszikus megközelítésekkel nem lehet osztályozható, és ez a társadalmi és kulturális határok átrajzolódásának a jobb megértését igénylik. Savage és társai szerint az osztályok között nem „zéró összegü játszmák” folynak, hanem sajátos „relációs versenyek” zajlanak. Az új osztályok kialakításának a célja a társadalmi és kulturális koherenciájának hangsúlyosabb figyelembe vétele. A cél nem a Goldhorpe sémával történő verseny, sem nem egy új - foglalkozáson alapuló - osztályséma kidolgozása, a modelljüket inkább úgy tervezték, hogy az jobban megvilágítsa a kulturális és társadalmi határok müködését, és azt, hogy ezek miként sugallhatják az osztályozás új vonalát (Savage et al. 2013; Savage 2015). Azt hangsúlyozzák, hogy olyan osztálykoncepcióra van szükség, amely nem redukálja azt egyetlen változó mércéjévé, hanem felismeri, hogy az egyenlőtlenség több tengelye hogyan kristályosodhat társadalmi osztállyá (Savage et al. 2014).

A „Brit Osztályfelmérést” (GBCS) ért rendkívül sok kritika ellenére Magyarországon is sor került egy hasonló adatgyüjtési módszerrel elvégzett kutatásra; ez az Osztálylétszám-20147 . Ebben a kutatásban is Bourdieu tőkeelméletét használták az osztályok megjelenítéséhez. A vizsgálat tárgya, hogy a gazdasági, társadalmi és kulturális töke birtoklása miként befolyásolja a magyar társadalom tagozódását. Hasonlóan a brit kutatókhoz, a látens osztályelemzés módszertanát alkalmazták és nyolc LCA-alapú osztályt ${ }^{8}$ határoztak meg: felső osztály, kulturális középosztály, gazdag középosztály, fiatal városi fogyasztók, hálózati tőkével rendelkező vidéki munkavállalók, sodródó fiatalok, középkorú depriváltak, prekariátusok. A kutatók arra a megállapításra jutnak, hogy a magyar társadalom meglehetősen hierarchikus, egy nagyon

${ }^{7}$ Az Osztálylétszám-2014 felmérést a Magyar Tudományos Akadémia Társadalomtudományi Kutatóközpontjának Politikatudományi Intézete és GfK Piackutató Intézet közösen végezte. A kutatás során 13.560 online kérdőívet sikerült kitölteni, illetve további 1.000 főt kérdeztek meg személyesen, ez utóbbit egy reprezentatív mintán.

${ }^{8}$ Ezek nevei angolul: upper class, cultural middle class, affluent middle class, young urban consumers, network-embedded rural workers, young drifters, middle-aged deprived, and the precariat 
éles határvonal van a felső négy és az alsó négy osztály között, ugyanakkor a felső és alsó rétegek is nagyon töredezettek (Albert et al. 2017). Egy másik eredmény a magyar társadalom „farnehéz” jellege (Róbert 2014), mely szerint a tömeg az alsó rétegek felé húz, illetve az, hogy óriási a szakadék a főváros/nagyvárosok lakói és kisvárosi/falusi lakóhelyen élök között. A tanulmányokból leszürt következtetés, hogy a stabil középosztály létrehozása a gazdasági és a politikai posztkommunista átalakulás során Magyarországon nagyrészt kudarcot vallott és hogy nem következett be a magyar társadalomban a várt „középosztályosodási” folyamat. A meghiúsult folyamat ellenére két olyan csoportot sikerült meghatározni, melyek a középosztályhoz hasonlítanak - ezek a „gazdag középosztály” és a „kulturális középosztály” - azonban ezek töredezettek és nehezebben azonosíthatóak. Az első csoport gazdaságilag gazdag, a másik pedig a kultúra és a hálózat szempontjából tehetősebb, tehát egyik csoport sem jellemezhető úgy, hogy megfeleljen egy meghatározott középosztály teljes profiljának, azaz a tőke mindhárom dimenziójában jól teljesítsen (Albert et al. 2017).

Az elemzésnek fontos tanulsága - különösen a posztkommunizmusból fakadó rétegződési jellegzetességek tekintetében - a középosztály kialakulásának elmaradása, ugyanakkor felhívja a figyelmet a többdimenziós adatgyüjtés és elemzés szükségességére.

A társadalmi struktúrakutatás diskurzusában körvonalazódik az osztályszerkezet-elemzés újragondolásának a szükségessége. Annak ellenére, hogy a társadalmi rétegződés és az osztályszerkezet rokonértelmű kifejezések, ezek mégsem azonosak és a két eljárást egymás kiegészítőjeként, nem egymással szemben kell használni (Éber 2020). Savage és társai az alkalmazott módszerek és teóriák pluralizmusának elfogadását, az osztály és a rétegződéskutatás többdimenziós megközelítését javasolják (Savage et al. 2013).

A foglalkozásszerkezet megalkotásának erőssége, hogy a pozíciók megkülönböztethetőek a munkaerőpiacon, de érvényességét csökkenti az, hogy az elmúlt évtizedekben jelentősen megnőtt azok aránya, akiknek nincsen vagy megváltozott a „munkajellegük”: a fiatalok még nem dolgoznak az idősek pedig már nem dolgoznak (Róbert 2015). A foglalkozásalapú megközelítések mellé fokozatosan bekerült az életmód, a fogyasztás, az érdekérvényesítés, kapcsolatok és a kultúra dimenziója is. 
A következő részekben a kulturális fogyasztás és osztályhelyzet kapcsolatát vizsgáló három fő elméleti megközelítést - homológiák tézise, individualizáció, illetve az omnivore-univore megközelítéseket - mutatjuk be.

\subsection{Homológiák tézise}

A homológia tézise szerint a társadalmi rétegződés és a kulturális rétegződés szoros kapcsolatban állnak, a felső rétegből származók a magas, illetve elit kultúra fogyasztói, az alsó osztálybeliek pedig a tömegkultúra fogyasztói. A homológiák feltételezése Bourdieu La Distinction című müvében (Bourdieu 1984) jelenik meg, két központi fogalma a mező és a habitus, amelyek kölcsönösen feltételezik egymást. Bourdieu (Bourdieu 1978c, 1978b) egyik legfontosabb elemzési egysége a társadalmi osztály, mely révén kapcsolatot teremt az osztályhabitusok és az egyéni habitusok között. A habitust az osztályhelyzetből adódó létfeltételek alakítják, amelyek egyúttal meghatározzák az egyén viselkedését, és befolyásolják, hogy hogyan észleli a világot. Bourdieu (Bourdieu 1978a, 1978b) értelmezésében a társadalmi reprodukció csoportok közötti konkurenciaharcban zajlik, s e küzdelem eszköze a gazdasági tőke mellett a kulturális és a társadalmi tőke is. A különböző tőkeformák bizonyos határok között egymással kölcsönösen kicserélhetők, a gazdasági tőke birtoklása például felhasználható a kulturális javak és privilégiumok megszerzéséhez. A kulturális tőke mértéke a tanulmányi-beruházási stratégiákat is meghatározza, mégpedig a társadalmi rétegekre jellemző habitus által. Azt feltételezi, hogy az erőforrások (készségek, stílus, modor, ízlés) kizárólag a felső társadalmi osztályokból származó fiatalok számára állnak rendelkezésére. A kulturális tőke reprodukciós funkcióját hangsúlyozza, vagyis azt a képességét, hogy a felső osztályból származók számára ennek felhalmozása akadálytalanul megy végbe. A kulturális tőke elsajátítása, koroktól, társadalmaktól és társadalmi osztályoktól függően különböző mértékben, teljesen öntudatlanul mehet végbe, másszóval a különböző kifejezési módok (színháztól a televízióig) az egyéni véleményektől független hierarchia mentén helyezkednek el, amely meghatározza a kulturális legitimitást. Bourdieu kulturális legitimitáson azt érti, hogy az egyén egy olyan 
szabályrendszerben él, amely lehetővé teszi, hogy viselkedését kulturális vonatkozásban minősítsék. A kulturális rétegek közül a felső rétegek diktálják a szabályrendszert és minősítik a többséget. Az alsóbb rétegek ezt a kulturális minősítést többnyire elfogadják. Tehát ez azt jelenti, hogy a legitimitás szférájába tartozó preferenciák és ismeretek hierarchikusan oszlanak el, másszóval a fogyasztási modellek hierarchikus rendszert alkotnak. (Bourdieu 1978a)

Zinnecker (1993) a fiatalok közötti különbségek magyarázatára Bourdieu kibővített tőkeelméletét használja, mely szerint az ifjúság a szülői társadalmi osztályhelyzet szerint szegmentálódik (Zinnecker 1993). A hatdimenziós osztályspecifikus ifjúságelemzési modell értelmében, a társadalmi térben elfoglalt szociális helyzet alapján, az ifjúság különböző habitusmódozatait vázolja fel. A felső réteg fiataljainak hatalmas játékterük van, és szinte korlátlan mértékben rendelkeznek a különböző tőkékkel, ami lehetővé teszi, hogy megtervezzék a társadalmi pozíció átvitelét, a kispolgárok, akik közepes tőkevolumennel rendelkeznek és végül a csekély tőkevolumennel rendelkező, alsó osztályból származó fiatalok (Zinnecker 1993).

Flemenn és társai úgy vélik, hogy Bourdieu-t sokan leegyszerüsítve értelmezik, felhívják a figyelmet arra, hogy a homológia tézise nem a kultúra szintjére és nem a müfajokra vonatkozik, inkább az életmód és a társadalmi tér konfigurációjának hasonlóságáról szól. Ugyanakkor azt is elismerik, hogy Bourdieu úgy is értelmezhető, hogy az „életmódra” épülő „státuscsoportok” domináns osztályok, hogy a státus látszólag legitimálja az osztály érdekeit. A státuscsoportok és a státusmegkülönböztetés tulajdonképpen álruhába öltöztetett osztályok, illetve osztálymegkülönböztetés. Azonban az osztály és a státus megkülönböztetésének elvetése helyett megmutatják, hogy a bourdieu-i fogalmak lehetővé teszik az analitikus különbségtételt az egyenlötlenség gazdasági és szimbolikus dimenziói között. Erős bizonyítékokat találnak a homológiáról, ahol az életmód és a társadalmi tér kölcsönös kapcsolatban áll a társadalmi osztálytudattal. Egyértelmü összefüggést mutatnak ki a társadalmi tér és az életmód között, vagyis az osztály- és státuszmeghatározás bizonyos mértékben a homológ logika szerint müködik (Flemmen-Jarness-Rosenlund 2019a). 
Tehát a fenti megközelítések szerint a mező, a pozíciók közötti viszonyok öszszessége és a habitus, gondolkodási és cselekvési diszpozíciók rendszere homológiai viszonyban állnak egymással. Az egyéni habitusok közötti különbségek a társadalmi pályaívek egyediségéből származnak.

\subsection{Individualizáció elmélet}

A fenti „homológia” elméletet sok kritika érte. Ezen kritikák egyike az individualizációs érv, ami szerint a késői modern társadalmakban megszünik az osztály szerinti tagozódás. Napjainkban egyre kevésbé releváns az osztályalapú megközelítés, a megnövekedett szabadidő és a jobb életfeltételek hatására sokkal jellemzőbbek a fogyasztáson alapuló életstílus-csoportok. Ez a fajta megközelítés Nyugat-Németországban bontakozott ki az 1980-as évek második felében (Beck 2004) (Hradil 1995) (Schulze 2000).

Beck alapgondolata, hogy a modern társadalomban a társadalmi egyenlötlenségek individualizálódtak és az osztálykategóriákat új társadalmi kategóriák váltották fel. Egyetért azzal, hogy a társadalmi egyenlőtlenség elosztási viszonyai állandók maradtak, de úgy gondolja, hogy a „rendi” színezetü osztályhelyzet hagyománya elvész, és megindul az élethelyzetek és életutak diverzifikálódása és individualizálódása, amely aláássa a társadalmi osztályok és rétegek hierarchia-modelljét (Beck 1999). Beck szerint a 21. században a globalizáció lett az egyik központi kérdés, ugyanis a globális méretü vállalkozások nemcsak a gazdaság alakításában játszanak szerepet, hanem a társadalom egészében változásokat eredményeztek. A globalizációval egyidőben ismeretlen hatókörü és erejü ,,individualizálódási folyamat” indult meg és tart ma is, amelynek során (a viszonylag magas materiális életszínvonal és az oktatási esélyek növekedésével, a mobilitási folyamatokkal) az egyének a történelmi hagyomány megtörésével kikerültek hagyományos kötődéseikböl, és kizárólag magukra, valamint saját egyéni életútjukra kell hagyatkozniuk (Beck 2005). Az individualizációt úgy látja, mint az osztályszerü társadalomszerveződés vetélytársát. Beck azonban nem az 
egyenlőtlenségek eltünéséről szól, amikor kijelenti, hogy nincs több társadalmi osztály. Éppen ellenkezőleg, úgy gondolja, hogy az egyenlőtlenségeket súlyosbítja a globalizáció, de az egyéneket már nem lehet csak két, négy, öt, hét vagy tizenegy kategóriába sorolni (Marian 2008).

Stefan Hradil (1995) is egyetért azzal, hogy a társadalom stratifikációját nem annyira a jövedelmi viszonyok határozzák meg, hanem egyre inkább a „miliőspecifikus életstílusok" (Hradil 1995). A hagyományos struktúramodell egy másik kritikusa (Schulze 2000) élménytársadalomként jellemzi az új társadalomtípust, ami azt jelenti, hogy a rohamosan terjedő élménypiaccal a fiatalok egyre inkább az élet megélése, átélése felé orientálódnak. A szükösség társadalmában a „kifele irányuló” cselekvés volt jellemző, a mai élménytársadalomban a „befele irányuló” cselekvés válik jellemzővé, vagyis a személyes élmények érzékelhetősége, ami nem csupán a szabadidőre korlátozódik, hanem a munka világában is jelen van. Az élménytársadalom csoportjait „társadalmi miliőknek” nevezi, amelyek az adott miliőre jellemző létformák, belső kommunikáció, illetve sajátos információfeldolgozás alapján különülnek el egymástól. Schulze nagy jelentőséget tulajdonít az életkornak a miliő szegmentálódásban. Úgy gondolja, hogy a mai élménytársadalomban kialakuló életstílusokat, csoportokat (miliőket) sokkal inkább az életkor, a személyes stílus és a képzettség határozza meg.

Clark és Lipset (Clark-Lipset 1991) amerikai szociológusok is arról írnak, hogy megszünt a társadalmak hierarchikus karaktere. Szerintük a társadalom rétegszerkezete fragmentálódott, mivel a nagyon széles életstílus-kínálatból mindenki kiválaszthatja a magának megfelelőt. A társadalom meghatározó strukturáló tényezőjének az életstílust tekintik.

Pakulski és Waters (1996) leginkább azt a nézetet bírálják, mely szerint az ízlés kijelöli és fenntartja az osztályhatárokat. Azt állítják, hogy az osztályok eltérő ízlése és preferenciái feloldódtak a tömegkultúrában és a társadalmi különbségek forrásává a fogyasztás válik, amelyet nem az osztályízlés, hanem a reklámok és a média termeli ki (Pakulski-Waters 1996).

A fent említett elméleti koncepciókat is számos kritika érte, a társadalomkutatók egy része úgy látja, hogy a mai társadalomban a vertikális és horizontális differenciálódás együttesen jelen van, ugyanis még mindig létezik egy olyan réteg, akik a 
„fogyasztói miliők alatt helyezkednek el”, és akiknek szabadidős aktivitásuk igencsak szegényes (Róbert 2015).

Bukodi (2010) szerint mind az individualizációs, mind pedig a homológiai megközelítés csak részben tud magyarázatot adni a mai modern társadalom kulturális stratifikációjára. Bár úgy véli, hogy a státuspozíció erősebb hatással érvényesül a kulturális fogyasztás rétegződésében, mint az osztálypozíció, mégsem lehet egyértelmü hatást megfogalmazni. A kulturális aktivitás növekszik ugyan az egyén státusával, azonban a kulturális aktivitás differenciálásában nem mutat szignifikáns kapcsolatot. Továbbá azt feltételezi, hogy a posztszocialista országokban a kulturális fogyasztás alakulását legerősebben az iskolai végzettség befolyásolja. Szignifikáns tényezőként emeli ki a család szerepét, különösen az apa státusát, ami a posztszocialista országokban még a rendszerváltást követően is erős hatással van a kulturális rétegződésre $(\mathrm{Bu}-$ kodi 2010).

Az életstíluskutatások a '80-as évek, de inkább a '90-es évek végén Romániában is megjelentek (Zamfir 1989; Sandu 1996; Bogdan 2001; Comșa 2006; Marian 2010). Dumitru Sandu a Romániában bekövetkező posztkommunista átmenetet egy utazáshoz hasonlítja, mely során új szempontok és nézőpontok tárulnak fel, új társadalmi problémák fogalmazódnak meg. Azt hangsúlyozza, hogy ebben az átmeneti állapotban a kutatási kérdéseknek a társadalmi aktorokra, értékekre és magatartásokra kell irányulniuk. Kutatásaiban - a regionális terek átalakulásában - egy olyan modellt próbál leírni, amelyben a gazdasági-infrastrukturális és demográfiai mutatók mellett a kulturális beágyazottságot is kiemelten fontosnak tartja (Sandu 1996).

Comsa Bourdieu társadalmi tér elméletéből kiindulva határozza meg a román lakosság társadalmi struktúráját. Véleménye szerint, különösen a nyugati társadalmakban a rétegződés klasszikus elméletei veszítettek relevanciájukból, és fokozatosan felváltják őket az új megkülönböztetések, a leggyakrabban prioritást élvező kulturális dimenziók (értékek, fogyasztás, önmeghatározás). Az életmód csoportokat egy kétdimenziós térben helyezi el, egy erőforrásdimenzió (anyagi, kulturális és kapcsolati tőke, egészség és életkor, egyéni modernitás), és egy helyzetmeghatározási dimenzió 
(jelenlegi helyzet, az előző évi helyzet, jövőbeli helyzet, illetve a szubjektív vagyoni helyzet) mentén, majd 12 csoportot határoz meg ${ }^{9}$ (Comșa 2006).

Marius Lazăr a Kulturális Fogyasztási Barométer címü kutatás alapján írja le a román lakosság kulturális fogyasztási módozatait. Főkomponens-elemzéssel kilenc fogyasztói csoportot különböztet meg ${ }^{10}$ és ezt követően a kulturális fogyasztás változókon elvégzett adatredukciós eljárás megismétlésével a kulturális fogyasztás társadalmi szegmentációjában 4 csoportot azonosít: idősebb, anyagi erőforrásokkal nem rendelkező, alacsony iskolai végzettségü, főként falusi lakhelyü személyek; képzett, anyagi erőforrásokkal rendelkező, többnyire városi fiatalok; vidéki kistelepülésen élő, szakiskolai vagy más középfokú végzettséggel rendelkező személyek; nagyvárosi, többségében bukaresti lakosok. Eredményei a romániai lakosság kulturális rétegzettségét tükrözik, azonban nem következtethetünk egyértelmüen arra, hogy létezne a kulturális viselkedésnek egyfajta „osztálykaraktere”. A társadalmi és kulturális rétegzettség, bár metszik, de nem fedik egymást. Ennek ellenére létezik egyfajta oppozíciórendszer, ami a férfiak és nők, az aktívak és inaktívak, fiatalok és idősek, „fehérgallérosok” és a „kékgallérosok”, a kisebbségiek és többségiek, nagyvárosiak és a vidéki lakosság közötti eltérő kulturális fogyasztási mintázatokban nyilvánul meg (Lazăr 2011).

Marian Vasile Giddens (1997) modelljéből indul ki, és az alapján írja le a román társadalom rétegződését. Elemzése során megerősíti, hogy a román társadalomban továbbra is meg lehet határozni osztályokat. ${ }^{11}$ Egy későbbi tanulmányában viszont azt a kérdést veti fel és bizonyítja be, hogy életmód elemzés még egy viszonylag szegény társadalomban is lehetséges, mint a román társadalom. Hat életstíluscsoportot határoz meg. ${ }^{12}$ Meglátása szerint az átmenet országaiban a horizontális tagozódás nem váltotta fel a vertikális tagozódást, de ugyanakkor kiemeli az életmód koncepciónak a

\footnotetext{
${ }^{9}$ Optimista szegények (7\%), optimista gazdagok (5\%) integrált pesszimisták (18\%) integrált optimisták $(18 \%)$, szegény nyugdíjasok $(15 \%)$, modern gazdagok $(7 \%)$, integrált hagyományőrzők $(5 \%)$, pesszimista gazdagok (7\%), szuper-pesszimisták és szegények (4\%), szuper pesszimisták $(4 \%)$ beteg nyugdíjasok $(9 \%)$

${ }^{10}$ kimaradás a kultúrából $(24,2 \%)$, etnocentrikus tradicionalizmus $(15 \%)$, ,trendi internethasználói” kultúra (9,3\%), nagyvárosi kultúra (könyvek, klasszikus zene, múzeumok 7,2\%), társadalmi státus-függö ifjúkori hedonizmus $(8,5 \%)$, a maszkulin versengés kultúrája $(6,4 \%)$, könyvízü, vidéki kultúra $(12,1 \%)$, női evazionizmus $(7,1 \%)$, kisebbségi kultúra $(10,3 \%)$

11 ipari alkalmazottak-beosztottak nélkül (52\%), szolgáltatásban dolgozók-beosztottak nélkül (18\%), szolgáltatásban dolgozók-beosztottakkal és beosztottak nélkül (nem fizikai és nem ismétlődő munkát végeznek) (9\%), szolgáltatásban dolgozók-beosztottakkal és beosztottak nélkül (fizikai és nem fizikai munkát végzők - ismétlődő) (9\%), alkalmazottak ás munkáltatók szolgáltatásban -beosztottakkal és beosztottak nélkül (7\%), alkalmazottak vagy önálló vállalkozók (mezőgazdaságban, beosztottak nélkül)

12 túlélök (22\%), megrekedtek (22\%), az átmenet nyertesei (16\%), (lehetséges) vállalkozók (15\%), racionális kísérletezők (15\%), időtlenek (10\%)
} 
fontosságát, ami arra kell késztesse a kutatókat, hogy a társadalmat több dimenzióban is megismerjék (Marian 2010).

\subsection{Az „omnivore-univore” elmélet}

Az „omnivore-univore” elmélet a homológia és az individualizáció elméleti megközelítéseket összesítve tárgyalja. Egyetért azzal, hogy a kulturális rétegződés továbbra is a szociális rétegződéssel magyarázható, viszont ezt nem az elit-tömeg kultúra szembeállításával teszi, hanem a mindenevő, illetve az egyoldalú fogyasztók kettősségének magyarázatával.

A kulturális mindenevőség fogalma Peterson-Simkus (1992) és Peterson-Kern (1996) szerzőpárosok nevéhez füződik, a zenei ízlést vizsgálva állapítják meg, hogy egyfajta történelmi váltás vette kezdetét. A „kultúr-sznobizmus”, amire egyfajta exkluzivitás volt jellemző, átalakul egy jóval nyitottabb, mindenevő stílussá, ami azt jelenti, hogy a magas kultúra és a populáris kultúra közötti választóvonal átjárhatóbbá válik (Peterson-Simkus 1992; Peterson-Kern 1996). Kristóf és Kmetty (2019) szintén a zenei ízlést helyezik a fókuszba és arra keresik a választ, hogy a magyar társadalomban kimutatható-e a kulturális mindenevőség jelensége. A különböző zenei müfajok kedvelése alapján határoznak meg tipológiákat, és azt vizsgálják, hogy ez hogyan függ össze a társadalmi státusszal. Elemzésük során 7 látens csoportot $^{13}$ alakítanak ki, és arra a következtetésre jutnak, hogy a két legfontosabb változó, ami kijelöli a zenei ízlésbeli csoportok határait az az életkor és a státus (foglalkozás és iskolázottság). Úgy vélik, hogy a valódi, extenzív kulturális mindenevőség inkább közép-, mint felsőosztálybeli sajátosság (Kristóf-Kmetty 2019).

Chan és Goldthorpe (Chan-Goldthorpe 2005, 2007b, 2007a) nemcsak a zenei ízlés tekintetében, hanem a különböző kulturális rendezvényeken való részvétel alapján vizsgálják a kulturális fogyasztás és társadalmi rétegződés kapcsolatát. Megállapításuk szerint a kulturális differenciálódás mint életstílus sokkal szorosabb

\footnotetext{
${ }^{13}$ szelektív mindenevő (10.8), extenzív mindenevő (16.2), rétegzenét kedvelő (17.5), rétegzenét elutasító (13.9), mindent elutasító (3), klasszikus zenét elutasító (15.4), csak mulatós és pop (23.2).
} 
kapcsolatban áll a státuspozícióval, mint az osztályhelyzettel. A kulturális fogyasztást úgy értelmezik, mint az önkifejezés egy módját, ami szoros kapcsolatban áll a státushelyzettel. A szerzők szerint a társadalmi rétegeződés és a kultúrafogyasztás közötti viszonyt a társadalmi státushelyzet és az iskolázottság befolyásolja leghangsúlyosabban. A kulturális mindenevők általában a magas státusú egyének, magasan iskolázottak, inkább urbánus környezetben élők, és főleg nők (Chan 2013). Egy későbbi cikkükben azt is sugallják, hogy a „mindenevő ízlés” széles, eklektikus kulturális ízlés, amely a társadalom felsőbb rétegeire jellemző, a tolerancia és nyitottság növekedését jelképezi mind esztétikai mind társadalmi szempontból. A mindenevőség egy kozmopolita posztmaterializmus kifejezése, nem pedig a megkülönböztetés új formája (Chan-Goldthorpe 2010; Chan 2013, 2019). Mind az individualizáció, mind pedig a homológia elméletét megkérdőjelezik, és elemzésükben arról írnak, hogy a kulturális fogyasztás differenciálódása inkább az „omnivore-univore” tengely mentén értelmezhetö, mintsem az elit és tömegkultúra tengelyén.

Sok vitát eredményezett a fenti állítást, miszerint a mindenevőség szemben áll azzal a megkülönböztetéssel, diszkriminációval vagy sznobizmussal, amelyet Bourdieu látott a magasra törő ízlésűek körében (Bourdieu 1984). Flemmen és társai élesen bírálják Goldthorpe és Chan megállapításait, akik egy olyan optimista szcenáriót vázolnak fel, ahol a mindenevők a legtöbb kultúrát, az „univore-ok” pedig a legkevesebbet fogyasztják, és a mindenevőség együtt jár egyfajta kozmopolitizmussal, nyitottsággal. Azzal érvelnek, hogy a mindenevők liberális politikai nézete nem jár egyértelmüen együtt a nyitottsággal, és hogy a mindenevő stílus nem lehet a megkülönböztetés egyik formája, mert az alternatív értelmezések is ugyanolyan valósak lehetnek (FlemmenJarness-Rosenlund 2019b). Különösen problematikusnak tartják azt, hogy Chan és Goldhorpe az osztály és státus fogalmát önálló, független változóként kezelik, ami azt eredményezheti, hogy az egyik faktor a másikat magyarázza. Flemmen és társai a „mindenevőséget” is megkérdőjelezik, ehelyett inkább visszatérnek egy „mindenevő előtti korszakba", hogy ellenőrizzék Bourdieu elméletét a társadalmi térről és az életmódról. Több dimenzióra támaszkodnak, a gazdasági tőke és a kulturális tőke mérésére egyidejüleg. 
Chan és Flemen megközelítése látszólag ellentmond egymásnak (Chan 2019; Flemmen-Jarness-Rosenlund 2019a), de valójában egymás kiegészítői, és jelentős előrelépést jelentenek a társadalmi rétegződés és kulturális fogyasztás megértésében. Bauman véleménye is azt tükrözi, hogy Flemmen és társainak megállapításai Chan kiegészítéseként is értelmezhetők. Chanhoz hasonlóan azt találják, hogy a nagy menynyiségű kulturális és gazdasági tőkével rendelkező emberek többek között a kozmopolitának tekinthető fogyasztási lehetőségek széles skáláját részesítik előnyben, mint például a világzene vagy a külföldi kortárs irodalom. (Baumann 2019)

Hanquinet azon a véleményen van, hogy bár a mindenevőség első látásra valamiféle kulturális demokrácia jele lehet, valójában nem kérdőjelezi meg a Bourdieu által felvetett kulturális megkülönböztetési és legitimációs mechanizmusok helytállóságát. A mindenevőség megjelenéséhez a kulturális hierarchiák fenntartására van szükségük, nem pedig összeomlásukra. (Hanquinet 2017) Több kutatás is igazolta, hogy a mindenevőség társadalmilag rétegzett jelenség, amely horizontálisan és vertikálisan egyaránt megkülönbözteti a társadalmi csoportokat. (Savage et al. 2013)

Lambert arra utal, hogy az elméleti következtetésekben megmutatkozó különbségek nagymértékben az eltérő módszertani stratégiáikból fakadnak, viszont megjegyzi, hogy a „státus” sokkal több dologhoz kapcsolódhat, mint az iskolai végzettség és a foglalkozás. Tehát Chan ezeknek az elemeknek az felhasználásával valószínüleg alábecsüli a státustudatot. Az „osztály” és a „státus” fogalmak fedhetik egymást, és ezeket a szerepeket egy beágyazottabb értelmezési keretben kell értelmezni (Lambert 2019).

Lizardo kissé mélyebbre megy vissza kritikájával, és azt mondja, hogy az osztályelemzés hagyományában elkövetett alapvető hiba, hogy azt sugallja, hogy egy kiváltságos módszer. Az egyének csoportokra történő felosztásához csak „,szuper titkos technikák” és „ultra-speciális elméletek” segítségével lehet eljutni (Lizardo 2019). Ezeket a csoportokat „osztályoknak” nevezték, és ezt követően az egyének felosztásának bármilyen más módja másodlagos lett. Az „osztály” az emberek felosztásának minden más módja felett helyezkedik el, valamiféle privilegizált térben, és régisége kiemeli a többi fogalom közül. Véleménye szerint ennek tükrében Chan és Goldhorpe elmélete teljesen legitim osztályozás, és semmivel sem rosszabb, mint amit Flemmen 
és társai használnak - csak más. Egy szójátékkal arra utal, hogy vannak emberek, akik egyfajta „RELAMAPRO”14 osztályokba tartoznak, és vannak, akik „schmatus” osztályokba. Érvelésével azt próbálja kiemelni, hogy nagyon sokféle osztályozás van, és ez értelemszerüen eltérő osztályokhoz és csoportosításokhoz vezet. Ebben a tekintetben egyetért Lambert megjegyzésével, hogy a módszerek igenis számítanak (Lambert 2019).

Warde, Wright és Modesto (Warde-Wright-Modesto 2007) is vizsgálták a kulturális mindenevőség fogalmát. Azt nézték meg, hogy milyen társadalmi jellemzők mentén írható le a „mindenevők” csoportja. Úgy vélik, hogy a „mindenevők” nem a domináns-felső osztály részei, mindazonáltal relatív privilegizált helyzetü és magasan iskolázott személyek, akik bár nyitottak a kulturális fogyasztás több irányában is, de bizonyos értelemben mégis elzárkóznak a tömegkultúrától.

Yoo Jin és Kyoung-Nan csatlakoznak az „omnivore-univore” paradigma érvényességének elemzéséhez. Kérdésük az, hogy a „kulturális mindenevőség” felbukkanása feloszlatja-e az osztályalapú megkülönböztetést a kulturális fogyasztás tekintetében. Vagy a mindenevő stílus egy új státus marker (státus jelző), ami lecseréli a régi zártkörü (exkluzív) kulturális elitet egy intellektuális elitre? A szerzők szerint a kulturális mindenevőség mint stílus reflektál az egyén státusára, a mindenevők magabiztosabbnak mutatkoznak a saját ízlésükben, és egy szofisztikáltabb, kifinomultabb önképpel rendelkeznek. A szerzők szerint a kozmopolita és a mindenevő stílus szinonimaként használható abban az értelemben, hogy mindkét esetben fontosnak tartják az esztétikai keretek változatosságát. A kulturális mindenevők olyan kozmopolita beállítottságú egyének, akik az ízlés tekintetében felsőbbrendűbbnek érzik magukat, mint a kevésbé mindenevők (less omnivorous), úgy gondolják, hogy kifinomultabb az ízlésviláguk (Yoo Jin-Kyoung Nan 2013).

Az „omnivore-univore” paradigma érvényességét magyarországi adatokon is vizsgálták (Bukodi 2010; Sági 2010). A magyar társadalom fogyasztói csoportjai között is jelen van a kulturális mindenevőség jelensége. Magyarázó tényezőként emelik

14 a RELAMAPRO egy osztályozás jelölése: (RE)lations in (LA)bour (MA)rkets and (PRO)duction units, amivel Chan aláhúzza az osztályozás relativitását - azaz azt, hogy bárki meghatározhat egy csoportosítást, és nem föltétlen lesz rosszabb, mint a másik (csupán csak más). 
ki a foglalkozást (Sági 2010), illetve az iskolai végzettséget (Bukodi 2010). Egyetértenek abban, hogy a modern társadalomban a kulturális fogyasztás egyre inkább „mindenevő” jelleget ölt magára, a jelenkori magyar társadalomban a kulturális mindenevők csoportja magas státusú egyénekből áll, magas iskolai végzetséggel, illetve elönyös családi háttérrel rendelkeznek.

A romániai szakirodalomban a „mindenevő” fogalmával a Kulturális Barométer felmérés jelentéseiben találkozunk. A román társadalomban három fogyasztói csoportot különböztetnek meg ${ }^{15}$ : (1) nem fogyasztók, inkább idősek, (2) szórakozásorientáltak, akik többnyire a szórakoztató tevekénységeket preferálják és középkorúak, valamint az (3) omnivore csoport, akik mind a szórakoztató, mind pedig a kulturális tevékenységében részt vesznek, átlagéletkoruk 28-29 év. A mindenevőség a társadalom egyötöd részére jellemző, akik magas iskolai végzettséggel és átlagon felüli jövedelemmel rendelkeznek (Marian 2010; Croitoru-Becuț 2017).

\section{7. Összefoglalás}

Az 1960-as évek közepéig a rétegződéselméletek enyhe dominanciája volt megfigyelhető, a hatvanas évek közepétől az osztályelméletek kerültek előtérbe, majd egyre növekedett a tudományon belüli elégedetlenség mind a rétegződés-, mind az osztályelméletekkel szemben. Ennek hatására számos próbálkozás történt az egyenlőtlenségi kérdések újrafogalmazására és a struktúraelméletek megújítására, ahova az életstílus- és miliőkutatások is illeszkednek.

Az életstílus-kutatások a nyolcvanas-kilencvenes években igen népszerüek voltak, és azt feltételezhettük, hogy paradigmaváltás történt, hogy az osztály- és rétegzödéselméletek „,kimentek a divatból”. Egyik ilyen meghatározó elméleti megközelítés Beck paradigmaváltó elmélete volt, miszerint a gazdasági fellendülés, oktatási expanzió hatására a szubkulturális osztályidentitások fokozódó mértékben elenyésznek, és megindul az élethelyzetek diverzifikálódása és individualizálódása, amely megváltoztatja a társadalmi osztályok és rétegek hierarchia-modelljét (Beck 2004).

\footnotetext{
${ }^{15}$ K-means klaszterelemzés módszerével.
} 
Beck érvelése miszerint a modern társadalomban individualizálódtak a társadalmi egyenlőtlenségek azon alapul, hogy egy általános életszínvonalbeli növekedés átalakította a hagyományos osztályalapú egyenlőtlenségek jelentőségét. Romániában, illetve Erdélyben nem volt olyan mértékü életszínvonalbeli növekedés, mint a Beck által vizsgált német társadalomban, viszont Romániában is észlelhető volt egy jóléti növekedés. A rendszerváltás utáni első évtizedben a legtöbb mutató tekintetében a változások a hanyatlás irányába mutattak, csökkent a nemzeti jövedelem, az oktatási mutatók. A rendszerváltás második évtizedében viszont (2001-2010) növekedés, fejlődés volt észlelhető, ezt követően pedig az EU-csatlakozási folyamat és tagság a társadalmi és gazdasági fejlődés ütemét szintén felgyorsította. Románia mutatói jobbak lettek 2010 óta, ami az 1990-es években még nem volt kimutatható (Veres 2018b).

Összefoglalva a homológia tézisét: a felső rétegből származók a magas-, illetve elitkultúra fogyasztói, az alsó osztálybeliek pedig a tömegkultúra fogyasztói, vagyis a fiatalok a szülők társadalmi osztályhelyzete szerint szegmentálódnak, és osztályhelyzetük szerint különböző habitusokat alakítanak ki.

Az individualizációs elmélet ezzel szemben azt állítja, hogy a kulturális minták függetlenednek az osztályhelyzettől, az életutak individualizálódnak, és a társadalom meghatározó strukturáló tényezőjének az életstílust tekinti. A kulturális szegmentálódás, kulturális ízlés és fogyasztás inkább a nem, az életkor és az etnikum szerint differenciálódik.

Az „omnivore-univore” elmélet szerint a kultúrafogyasztási exkluzivitás eltünik, és a kulturális rétegződést nem egy elit-tömeg kultúra szembeállításával magyarázza, hanem a mindenevő és egyoldalú fogyasztók kettősségének magyarázatával.

Annak ellenére, hogy a kilencvenes évek második felétől sok kritika érte az életstílus-kutatások létjogosultságát - elsősorban túl radikálisnak vélték a paradigmaváltással kapcsolatos törekvéseket, másrészt hiányolták az életstílus fogalmának pontosabb definiálását és az operacionalizálás felületességét. ${ }^{16}$ - az életstílus-kutatók többsége nem leváltani kívánta a hagyományos elméleteket, csupán kiegészíteni a hagyományos koncepciókat. Jörg Rössel mutatott rá arra, hogy az életstílus, a miliő és az

\footnotetext{
${ }^{16}$ Részletesebben lásd Berger (2008-as tanulmányában)
} 
osztály, illetve réteg fogalmai nem zárják ki egymást (Berger 2008). Tehát a kétféle elgondolást, megközelítést nem egymás alternatívájaként kell értelmezni, inkább közelíteni egymáshoz (Berger 2008).

Jelen dolgozat is az eltérő elméleti megközelítések összehangolásának a szükségességére hívja fel a figyelmet; ezek segítségével rajzolja meg a mai fiatalok társadalmi és kulturális szegmentációját. 


\section{Ifjúságelméleti megközelítések}

\subsection{Bevezetés}

Az ifjúságszociológia diskurzusában is élénk vita van azzal kapcsolatosan, hogy a modern társadalmak ifjúságát képesek-e megragadni a klasszikus magyarázó modellek, több iskola „verseng egymással” a fiatalokat érintő társadalmi kérdések értelmezésében. Az egyik ilyen vita, ami a társadalomtudományok egészében jelen van, hogy milyen perspektívából vizsgáljuk a fiatalok helyzetét, milyen változókat használjunk, amikor a fiatalok társadalmi struktúrában elfoglalt helyét szeretnénk megérteni. Ezek a viták leginkább a struktúra versus aktor dichotómia köré épültek, az egyik megközelítés szerint a fiatalok helyzetét a társadalmi struktúrák és azok strukturáló tényezői befolyásolják, a másik megközelítés szerint a hangsúly az egyén által meghozott döntéseken van (Szanyi-F. 2018).

\subsection{Elméleti diskurzusok az ifjúságkutatásban}

Az ifjúságszociológiában jelenlévő „iskolák” egyike a szubkultúra-elmélet, amely azt vizsgálta, hogy a fogyasztás milyen szerepet játszik az osztálytudat kifejezésében, és ezt elsősorban a munkásosztály kulturális fogyasztásával kötötte össze. Az első nagyobb ifjúsági szubkultúrakutatások - a Chicagói Iskola keretében - az ifjúkori bünözői és más deviáns viselkedésekkel kapcsolatos kérdésekre koncentráltak. Ezt követően a '70-es, '80-as években megjelenő $\operatorname{CCCS}^{17}$ kutatások hatására a hangsúly áthelyeződik a stílusközpontú ifjúsági kultúrák irányába (Bennett 2005).

A CCCS elméleti megközelítéseiben tetten érhető a marxista értelmezési keretek hatása: a szubkultúrákat a mélyebb társadalmi struktúrák és erőviszonyok

\footnotetext{
${ }^{17}$ Center for Contemporary Cultural Studies. A birminghami Kortárs Kritikai Kultúrakutatási Központ
} 
kifejeződéseinek tekintették (Kacsuk 2005). A képviselők egy része szerint a társadalmi osztályok fogyasztásában megjelenő különbségek nem tüntek el (Croghan et al. 2006; Griffin 2011). Phil Cohen osztályközpontú értelmezése szerint a brit ifjúsági szubkultúrák a szülőkultúrájuk, a munkásosztályi kultúra válságaira adott válaszkísérletek (Cohen 1997). A szubkultúrához tartozó fiatalok ebben a megközelítésben a munkásosztályhoz tartoznak. A CCCS kutatások eredményeit sok kritika érte. A szubkultúra-kutatás kritikájához kapcsolódóan kibontakozó posztszubkultúra-kutatás a kulturális fogyasztást nem osztályalapúként, hanem ízlésalapúként írja le.

Sarah Thornton - Bourdieu tőkeelméletére építve - párhuzamot von a szubkultúrák és a magas-, illetve elitkultúra között. Rávilágít, hogy a szubkultúra világára, a magaskultúrához hasonlóan, jellemző egyfajta ízléshierarchia. Ugyanakkor bevezette az „osztálytalanság” fogalmát, miszerint a tánczene kulturális fogyasztása az osztályokból való kilépést jelenti a fiatalok számára, mert úgy látja, hogy a felső, és a középosztálybeli ifjúság bizonyos elemeket elfogad a munkásosztálybeliek szokásaiból (Thornton 1996).

Muggleton azt feltételezi, hogy a posztmodern szubkultúrákban egyre nehezebb fenntartani a szubkultúra határait, a stílusok közötti átjárások felületesebbé fognak válni, és ezáltal a szubkulturális kötődések is. A fiatalok életében egy felfokozott individualizmus van jelen, és ebben kiemelt szerepet kap az önértelmezés (Muggleton 2000). Andy Bennett is amellett érvel, hogy a fogyasztói lét lehetőséget teremtett a fiataloknak arra, hogy elszakadjanak az osztályalapú identitásuktól, és a saját maguk által létrehozott identitással kísérletezzenek (Bennett 2005).

Az a kulcsfontosságú kérdés, hogy a fiatalok körében a társadalmi-gazdasági megosztottság egyéni élethelyzetek révén individualizálódik avagy az osztálykapcsolatokban található, ma is vitatott. A társadalmi hasadások a fiatalok körében továbbra is homályosak maradtak, a kilencvenes évekre az ifjúságszociológia kutatóit számos kihívás elé állította a tény, hogy az ifjúsági életpályák szerkezete is jelentősen átalakult, kitolódott az önálló, felnőtt létbe való belépés.

Az egyik ilyen elmélet az ifjúsági korszakváltás elmélete, ami Zinnecker nevéhez kapcsolódik. Az „ifjúsági korszakváltás” értelmezése az 1980-as évektől foglalkoztatja a társadalomtudósokat, melyet Jürgen Zinnecker (1986) német szociológus vezetett be a szociológia szakirodalmába. Két ifjúsági korszakról beszél: az egyik az indusztriális társadalomra jellemző átmeneti ifjúsági korszak, a másik a posztindusztriális társadalom iskolai ifjúsági korszaka. Az átmeneti korszakban a fiatalok szorosan kötődnek a felnőttek intézményeihez (munkahely, család, szomszédság), a 
társadalmi élet terén a fiatalok, a kezdők társadalmi pozícióját foglalják el, a munkában, a családban, a társadalomban alárendelt szerepet játszanak, kevés felelősséggel (Zinnecker, 1993). Az iskolai ifjúsági korszakban felértékelődik az iskola szerepe, a fiatalok egyre hosszabb időt töltenek az iskolában, ez az, ami meghatározza további életkarrierjüket, és ehhez igazodik a munkába állás, a házasodás és a gyerekvállalás, melyek mind későbbre tolódnak. Más életesemények előbb következnek be, mint például önálló szórakozás, utazás, sajátos fogyasztói státus kialakulása. Egy másik fontos jellemzője ennek a korszaknak, hogy csökken a családi, szomszédsági viszonyoknak, a településnek az ellenőrző szerepe, és felerősödik a fogyasztói ipar és a média szerepe. Ebben az életszakaszban megnövekszik a fiatalok autonómiája, az ifjúsági kultúrának a szerepe (Zinnecker, 1993). Mivel a kulturális tőke elsajátításának folyamata időigényes, a kulturális tőkéhez iskolai életút vezet, következésképpen a kulturális tőke fontosabbá válása meghosszabbítja az ifjúkort. Minél több ideje van a fiatalnak arra, hogy kulturális tőkére tegyen szert, annál előnyösebb helyzetbe kerül, ez nagyobb autonómiát, függetlenséget eredményez.

A társadalmi, gazdasági fejlődés következtében a nyugat-európai posztindusztriális társadalmakban egyre inkább a kulturális tőke megszerzése válik uralkodóvá, ami együtt jár az ifjúsági korszakváltással.

Nyugat-Európában a '60-as évektől kezdődően, a '80-as években következett be az ifjúsági korszakváltás, Közép- és Kelet-Európában (mind Romániában, mind pedig Magyarországon) ez a folyamat az államszocializmus alatt késleltetett volt. Magyarországon és Romániában a kilencvenes évek elejétől beszélhetünk ifjúsági korszakváltásról (Gábor 2006b; Veres 2006). Az átmeneti korszakban egy korlátozott ifjúkorról van szó, a posztindusztriális korban az ifjúkor egyre inkább kitolódik, mely szoros összefüggésben van az iskolai idő megnövekedésével, a fiatalok időt kapnak arra, hogy különböző intézményeket megismerjenek, társadalmi kapcsolatokat alakítsanak ki. A fiatalság egyre nagyobb önállóságot vív ki magának, és ez a fajta önállóság újfajta értékrendet és kulturális mintát alakít ki, mely elsősorban fogyasztás- és szabadidő-orientált (Ercsei et al., 2011; Gábor - Veres, 2011).

A kutatók felhívják a figyelmet a folyamat osztály/rétegspecifikus jellegére, miszerint az ifjúsági korszakváltás eltérően érvényesül a fiatalok különböző szegmensein. Chisholm és Wattson szerint (1987) a munkanélküliségi forgatókönyvet, miszerint az „angol társadalom túl messzire ment el a munkanélküliségi szcenárió felé 
vezető úton, ahhoz, hogy a foglalkoztatási szcenárió felé vegye az irányt” a kilencvenes években is érvényesnek gondolják az angol társadalomra (Chisholm 2006). A munkanélküliségi szcenárió mellett még három másik valószínüsíthető szcenáriót is említenek: a szabadidő megnövekedésének szcenárióját, a foglalkoztatási-, illetve a munka-szcenáriót (Chisholm 2006).

Wallace (1998) is rámutat arra, hogy számos strukturális változás következik be a fiatalok életében. A fiatalok egyre bizonytalanabb lépcsőket járnak be, amikor a képzés világából átlépnek a munka világába, éppen ezért egy átmeneti állapotot választanak, az egyetem mellett elkezdenek dolgozni, illetve a munka mellett még tovább tanulnak azért, hogy ezt a bizonytalanságot valamennyire kiküszöbölhessék. Továbbá jelentős munkaerő-piaci változásoknak lehetünk tanúi, nem tervezhető, hogy a képzési szakaszt munka és egy egész életre szóló munkahely követi (Wallace 1998).

A fiatalok életében nemcsak a munkavállalás terén vannak változások, hanem a szabadidő-eltöltés és szórakozás feltételei is megváltoznak (Chisholm 2006; Fekete 2018; Szabó-Hires-László 2018). A kilencvenes évek kelet-európai ifjúsági korszakváltása során a fogyasztás szerepe meghatározóvá válik, míg a korábbi kapitalizmusokat a szükösség, a korlátozott lehetőségek és az erős társadalmi hierarchia határozta meg. A bőség társadalmát az élmények keresése, a tág lehetőségek és kapcsolatok választása, a vertikális és horizontális hierarchiák keveredése jellemzi (Gábor, 2009). Romániában is az 1989-es rendszerváltással gyökeres társadalmi változások vették kezdetüket. Az új politikai és gazdasági pilléreken kialakuló rendszer fokozatosan helyet adott azoknak a folyamatoknak, amelyek az ifjúsági korszakváltás irányába hatottak. Bár Romániában a piacgazdaság kiépülése (ld. Veres 2005), illetve az oktatás expanziója is (Papp 1998, Hatoş 2006) viszonylag lassan ment végbe, a vonatkozó vizsgálatok arra engednek következtetni, hogy az ifjúsági korszakváltás folyamata, egyrészt réteg/osztályspecifikusan, másrészt sajátos módon, ám mindenképpen kiszélesedőben, felgyorsulóban volt (lásd Ercsei - Kiss - Szabó 2011; Gábor - Veres 2011).

A modern társadalom, illetve a globalizáció révén a hangsúly a termelésről a fogyasztásra helyeződött át, ami maga után vonta a szabadidő felértékelődését, és megteremtett egy úgynevezett szabadidős forgatókönyvet. A fiatalok szabadidős tevékenységében igen fontossá válik a fogyasztás, a kiépülő szabadidőipar, a 
szórakoztató és fogyasztói ipar során egyre inkább előtérbe kerül a változatos, érdekes élet. (Ercsei et al., 2011). A fogyasztás a kelet-európai fiatalok körében is meghatározóvá válik, a kilencvenes évek elején bekövetkezett ifjúsági korszakváltása hatására a fiatalság egyre nagyobb önállóságot vív ki magának. Ez a fajta önállóság újfajta értékrendet és kulturális mintát alakít ki, mely elsősorban fogyasztás- és szabadidő-orientált (Ercsei-Kiss-Szabó 2011; Gábor-Veres 2011).

A fogyasztói társadalom kialakulása különösen a fiatalok életmódját érinti hangsúlyosan, egyre nagyobb a fogyasztási kényszer, ami jelentős strukturális változást eredményez, a fiatalok egyre inkább a fogyasztói stílusok tekintetében differenciálódnak, bár lehetőségeik a fogyasztásra igen egyenlőtlenek. A fogyasztás szorosan öszszefügg a társadalmi rétegződéssel, az úgynevezett szolgáltató-információs társadalomban az anyagi és kulturális fogyasztás a társadalmi rétegződés legfontosabb öszszetevői (Fábián-Kolosi-Róbert 2000), és az egyének társadalmi pozíciója egyre inkább a fogyasztás révén fejeződik ki. Róbert Péter szerint különösen a kelet-európai társadalmak esetében relevánsak az életstílus kutatások, mert míg a hagyományos rétegződési vizsgálatok viszonylag alacsony társadalmi különbségeket tárnak fel, addig az életstílus vizsgálatok a társadalmi egyenlőtlenségek újratermelésének jellegzetes formáiról számolnak be (Róbert, 1999).

Az ifjúsági korszakváltást összekapcsolják a középosztályosodás kérdésével: a német kutatók szerint a társadalom csaknem egésze jómódú középosztállyá válik, a brit kutatók ezzel szemben a „társadalom alatti osztálytézist” hangsúlyozzák, miszerint a jómódú többség és a leszakadt kisebbség közötti különbségek elmélyültek (Chisholm 2006). Szerintük az ifjúságkutatásban a vertikális és horizontális értelmezési kereteket együtt kell alkalmazni, a strukturális tényezők arra utalnak, hogy az ifjúságkutatásnak mint társadalmi kategóriának az arculata továbbra is igen heterogén marad (Chisholm 2006).

Egy másik megközelítés a zinneckeri megközelítés, aki Bourdieu elméletét használja az ifjúság betagolódásának leírására. Zinnecker szerint az ifjúság a szülői társadalmi osztályhelyzet szerint szegmentálódik, amelyet a rendelkezésre álló kulturális és gazdasági tőke mennyisége határoz meg. Az osztályspecifikus habitus és az ifjúság ideológiai koncepciói között összefüggést fedez fel, és három ifjúsági habitust különböztet meg. A felső rétegekre az ifjúkor meghosszabbítása, az idővel való 
„pazarló” bánásmód jellemző. A kispolgárok esetében az ifjúság fogalma a képzési karrier idejére korlátozódik, nincs olyan mértékü autonómiájuk, mint a felső rétegből származóknak, az ifjúkor optimalizálására és racionalizálására törekszenek. A gyermekkori státusból vezető utat a felnőtt státushoz saját teljesítménnyel kell megszerezni, ami azt jelenti, hogy egy korlátozott ifjúsági életről van szó. Végül az alsó osztályból származó fiatalok esetében az ifjúkor siettetésének a kényszere uralkodik és ez nem hagyja kibontakozni az ifjúságot. „A státus átmenet megrövidítése és siettetése sem a gyakorlatban, sem az ideológiában nem hagyja kibontakozni az ifjúságot”' (Zinnecker 1993, 2006).

Az átmenet- és szubkultúra-elméletek közös pontja volt a fiatalok osztályalapú vizsgálata, amelyet Beck '90-es években megjelenő Kockázati társadalom címü könyve megkérdőjelezett. Beck paradigmaváltó diskurzusa szerint a modern társadalomban a gazdaság termelése együtt jár a társadalmi kockázatok termelésével (Beck, 2005), az élethelyzetek és életstílusok individualizálódásával. A fiatalok maguk válnak felelössé életútjuk alakításáért, és bár a kiszélesedett döntési térben lehetőségük van az esetleges rossz döntéseik javítására, az egyének több kockázattal kell szembenézzenek, nagyobb bizonytalansággal kell megküzdjenek. Beck azt is jelzi, hogy a kockázatok bizonyos csoportokat jobban érintenek, kiemelve a nöket és a fiatalokat, illetve a szegényebb csoportokat, akik még sebezhetőbbé válnak.

Az életutak individualizálódása, ami Beck szerint háttérbe szorítja a szubkulturális alapú osztályidentitásokat nagy vitát eredményezett az ifjúságszociológiában is. A Becket kritizáló szociológusok jelentős része elsősorban a társadalmi osztályok szerepének megkérdőjelezése miatt támadta. France és Roberts (2018) szerint az osztályokat „vissza kell helyezni a térképre” és nagyobb hangsúlyt fektetni az osztály és a kiváltság (privilege) fogalmaira, így jobban megismerhetővé válnak a fiatalok közötti egyenlőtlenségek. A bourdieu-i megközelítéshez kapcsolódnak, melyben az osztály fogalma is jelen van, ugyanakkor a társadalmi egyenlőtlenségek vertikális elrendeződése is, mégpedig az anyagi, kulturális, és kapcsolati tőkére vonatkozó elméletében (France-Roberts-Wood 2018).

Woodman szerint az ifjúságszociológiai tanulmányok gyakran tévesen értelmezik Beck választott életutak - „,choice biography” - fogalmát, és ez ezzel kapcsolatos 
egyenlőtlenségi kérdéseket (Woodman 2009). Véleménye szerint Beck ezt a fogalmat segédként használta, az egyént mint ágens (agency) fogalmának a hangsúlyozására. Tulajdonképpen egy olyan álláspontot képvisel, ami a struktúra és az ágens között helyezkedik el.

Roberts szerint Beck individualizáció elmélete egyértelmüen elutasítja a strukturális különbségeket, tehát az ifjúságkutatók nem indokolatlanul látták ezt az összefüggést. (Roberts 2010)

Woodman azt javasolja, hogy Beck érveléseit érdemes fontolóra venni, azoknak is, akik hasznosnak találják Beck individualizációs érveléseit, és azoknak is, akik ezt elutasítják, ugyanis Beck egy új gondolkodásmódot és módszert javasol a kortárs egyenlőtlenségek feltárásához. Azt a fontos kérdést fogalmazza meg, hogy vajon a huszadik századi szociológia fogalmai megfelelnek-e a kortárs társadalom egyenlőtlenségeinek a leírásához. (Woodman 2009, 2010) Beck nem kérdőjelezi meg az egyenlőtlenségek csökkenését, hanem ,a konstans egyenlőtlenségi viszonyok palástja alatt" érzékel egy mindeddig ismeretlen erejü társadalmi individualizálódási folyamatot. (Beck 2004: 527) Sőt azt is belátja, hogy: ,aki ma elhagyja a kutatási rutin ösvényeit és újra napirendre tüzi az egyenlőtlenségkutatás tárgyának és miértjének kérdését, az egy látszólag ellentmondásos ténnyel kerül szembe” (Beck 2004: 484)

Beckhez hasonlóan Blossfeld és társai szintén kiemelik a globalizációs folyamatok szerepét, és azt feltételezik, hogy hatásai makro-elméleti szinten a legtöbb modern társadalomban tetten érhetőek, de ezen hatások országonként eltérőek lehetnek. Ugyanakkor a vizsgált országok mindegyikében azt figyelték meg, hogy a kockázatok a különböző életszakaszban lévőket eltérő mértékben érintik. A globalizációval járó bizonytalanság a társadalmi csoportok közül legjobban a fiatalokat sújtja, döntéseiket ebben a megváltozott, bizonytalan térben kell meghozniuk. Blossfeld szerint a globalizációs folyamatok fő vesztesei a fiatalok. (Mills-Hans-Peter 2005)

Standing szintén a globalizációs környezetbe értelmezi az egyenlőtlenségeket, és azt látja, hogy a liberalizált piacok egy globális osztályszerkezet kialakulásához vezettek, amelybe új csoportok jelentek meg, és ahol szintén a fiatalok a vesztesek. 
Az új struktúra, amit meghatároz hét ${ }^{18}$ csoportból áll, amelynek az alján elhelyezkedő újonnan megjelenő csoport a globális prekariátus gyorsan növekvő osztálya. A prekariátusok osztályának nagyrészét a fiatalok teszik ki, ami egy „rugalmas és bizonytalan munkaviszonyú tömeg”. (Standing 2012b: 588). „A fiatalok adják a prekariátus erejét és dühét is" (Standing 2012a: 37), akik komoly státuszfrusztrációt élnek át. Az egyre több iskola és képzés elvégzése után abban reménykednek, hogy kedvező állást kapnak az álláspiacon, azonban a fiataloknak egy életre alkalmazkodniuk kell a rugalmassághoz: „ma a munka világába belépő fiatal ritkán talál olyan szakmát, mely olyan, mint tegnap volt, és számolnia kell azzal, hogy holnap sem lesz már ugyanolyan, mint ma”. (Standing 2012b).

Ferge Zsuzsa Standing osztálystruktúrájával kapcsolatosan jegyzi meg, hogy ő igen óvatosan bánik az „osztály” fogalmával. Ugyan nem tekinti érvénytelennek az osztály fogalmát, de ezt sokkal világosabban kell meghatározni, mielött ezt a címkét társítjuk egy csoporthoz. (Ferge 2012)

\subsection{Kísérletek a magyarországi fiatalok társadalmi helyzetének leírására}

A magyarországi rétegződés vizsgálatnak több évtizedes hagyománya van (Ferge 1969; Fábián-Róbert-Szívós 1998; Fábián-Kolosi-Róbert 2000; Kolosi 2000; Fábián 2015), több modellt is kidolgoztak az egyenlőtlenségek leírására, ezeket az előző fejezetekben részletesebben is tárgyaltunk.

A fenti elemzések a horizontális különbségek mellett figyelembe veszik a társadalmi státus szerinti hierarchikus különbségeket is, úgy vélik, hogy a társadalomban a vertikális és horizontális rétegződés együttesen van jelen, és amellett érvelnek, hogy a fogyasztás jobban kijelöli az egyén helyét a társadalomban (Fábián-Kolosi-Róbert 2000). A fiatalok esetében ez fokozottabban érvényesül. A fiatalok rétegződésének vizsgálatára azonban kevesebb figyelmet szenteltek, ennek oka bizonyára az, hogy

\footnotetext{
18 Elit, alkalmazotti réteg, szakember, munkásosztály-mag, prekariátusok, munkanélküliek, lumpenprekariátusok
} 
nincs egyetértés abban, milyen releváns változókat kell figyelembe venni, amikor a fiatalok társadalomban elfoglalt helyét akarjuk megérteni.

Az ezredforduló után készült ifjúságkutatások eredményeire támaszkodva Bauer és társai hat dimenzió szerint vizsgálták a magyarországi fiatal korosztályt: tudástőke, anyagi tőke, szocio-demográfiai változók, életmód és kulturális fogyasztás. Ez alapján 22 társadalmi csoportot azonosítottak, majd ebből alakítottak ki 3 réteget (a rendszerváltozás nyertesei, a rendszerváltás túlélöi - köztes réteg, a rendszerváltozás vesztesei). A rétegek hierarchiát képeznek, de az egyes rétegen belüli csoportok között horizontális kapcsolatot is feltételeztek. A csoportosításból az is kiderül, hogy a lakóhely urbanizáltsága fontos paraméter, a falvakban élő fiatalok gyakran kerültek a vesztesek közé (Bauer et al. 2003).

Bő egy évtízeddel az előbbi felmérés után, a 2012-es, negyedik magyarországi nagymintás ifjúságkutatás alapján Nagy Ádám újra elvégezte ezt a csoportosítást hasonló dimenziók (demográfia, szubjektív helyzetértékelés, médiafogyasztás, kulturális terek látogatottsága, sport, kockázati magatartások) mentén, és 15 homogén csoportot $^{19}$ állapított meg. Abból a hipotézisből indult ki, hogy egy évtízed alatt a fiatalok körében alapvetően átalakultak a csoportok és rétegek. Sajnálatos módon a két felmérés eredményeinek összehasonlítása elmaradt, a szerző a módszertani leírást hiányolja a Bauer és társai tanulmányában, melynek hiányában a két periódusban elvégzett rétegződési vizsgálat összevethetetlenné válik (Nagy 2014a).

További fiatalokkal kapcsolatos elemzések a Sziget felmérések ${ }^{20}$ alapján láttak napvilágot. A középosztályosodási jelenségek megnyilvánulási formáit közép-európai kontextusban az ifjúság körében Gábor Kálmán elemezte részletesen (ld. Gábor 1996, 2000, 2004, 2005a). Azt vizsgálta, hogy a kilencvenes évek kelet-európai ifjúsági korszakváltása során milyen strukturális változások következtek be az ifjúság életében. Hogyan alakították át a fiatalok helyzetét azok a társadalmi folyamatok, amelyek a rendszerváltás után következtek be és erősödtek fel, mint pl. a fogyasztás szerepének

\footnotetext{
19 Átlag feletti tőkével bíró csoport (23\%): Nevelt kulturális elit, gondtalan optimisták, megkapaszkodott fiúk. Átlagos tőkemennyiséggel rendelkezők (43\%): kiegyensúlyozott közép, kényelmes álmodozók, pesszimista közép, perspektivikus kultúrafogyasztói tizenévesek. Átlag alatti tőkekoncentrációval jellemezhetők (17\%): kitörni vágyók; lecsúszott, de nyitott optimisták; reménytelenül beragadók; bulizós veszélyeztetettek; passzív, megállapodott deprivált nők. Inkonzisztensek (18\%): Arctalanok, jó hátterü urbánus kísérletező fiúk, menekülők.

${ }^{20}$ Gábor Kálmán vezetésével 1997-ben kutatássorozat indul a Sziget Fesztiválon, azzal a hipotézissel, hogy a „Sziget a jövendőbeli középosztályé”.
} 
megnövekedése, az ifjúsági korszak kitolódása és a szabadidő felértékelődése, élmények keresése, az információs társadalom adta tág lehetőségek és kapcsolatok. Hogyan kapcsolódik össze az ifjúsági korszakváltás a fiatalok középosztályosodásával, rákérdezve a fesztiválozó fiatalok osztálytudatára. Egyik alapvető állításuk, hogy a Sziget, mint élménykultúra, a középosztálytudat kialakításának fontos színterévé válik. (Gábor-Gaul-Szemerszki 2006).

Gábor Kálmán (2006) szerint Magyarországon egy korlátozott, az NSZK-ban pedig egy meghosszabbított moratóriumról van szó, a társadalmi strukturális különbségek inkább jellemzik a magyar, mint a nyugatnémet fiatalokat, a városi és vidéki fiatalok közötti különbségek is erőteljesebben nyilvánulnak meg a magyar társadalomban (Gábor 2006a).

Az eddigi elemzésekhez képest Kabai (2006) a fiatalok rétegződését vizsgálva egy új kísérleti modell kidolgozására vállalkozott. Kiindulópontja elsősorban Beck munkája, ami magyarul 2003-ban jelent meg A kockázat-társadalom címmel. Egy új rétegképző dimenziót, az „egyéni életutat” emeli be elemzésébe. Kabai és társai úgy vélik, hogy a posztmodern világban élő fiatalok helyzetét a „klasszikus rétegképző tényezőknél" erősebben határozza meg életútjuk alakulása (Kabai-Iharosi-Kabainé Tóth 2018). Következtetéseikben azt fogalmazzák meg, hogy az életútelemek hatása a legerősebb az elégedettség alakulásában. Ezt követően a második legerősebb magyarázó változó a saját réteghelyzet, a harmadik a háttérelemek, míg a - relatíve leggyengébb a szülői réteghelyzet magyarázó ereje. Kabai munkáját számos kritika érte, egyrészt azt emelték ki, hogy Beck nem a poszt-szocialista Kelet-Közép-Európa tapasztalatait teoretizálta, így nem biztos, hogy ez a legjobb kiindulópont. Másrészt a kutatók úgy vélik, hogy az életesemény „nem vált rétegképzővé”, inkább a kutatók döntöttek úgy, hogy az életeseményeket bevonják a magyarázómodellbe, majd ezt a döntésüket empirikus elemzéssel próbálták igazolni (Éber 2016). Mi a leginkább azzal a kritikával tudunk egyetérteni, hogy a négydimenziós rétegmodell mögött nem áll letisztult társadalomkép, így a modell továbbra is csak egy elméleti konstrukció marad. (Harcsa 2016).

További két, fiatalokat célzó, rétegződés vizsgálat inkább a horizontális különbségek feltárására fekteti a hangsúlyt, de ugyanakkor figyelembe veszi a gazdasági 
dimenziók mentén létrejövő hierarchikus különbségeket is. Fekete és Prazsák a fiatalok kulturális rétegződését vizsgálva négy kultúrafogyasztói csoportot határoznak meg: kulturálisan szegény, könnyed szórakozó, omnivore, elit. Az így kialakult csoportokat kulturális kasztrendszernek nevezik, melyek jellemzői, hogy az alacsonyabb társadalmi státusz szegényesebb kulturális aktivitással, a magasabb pedig gazdagabb kulturális részvétellel jár. Úgy látják, hogy a gazdasági helyzet egyrészt megszünteti a kulturális kasztok közötti mobilitási csatornákat, másrészt gondoskodik az autonómia és a heteronómia újratermelődéséről. A kulturális kasztok határai jól összefüggenek a posztadoleszcenciával, a rendszeresebb és aktívabb kulturális részvétel együtt jár az autonómiára irányuló igénnyel (Fekete-Prazsák 2014).

A Magyar Ifjúság 2012 felméréshez kapcsolódóan három olyan tanulmánykötet is napvilágot látott, amelybe a fiatalok rétegszerkezetét, különböző elméleti megközelítésből vizsgálják. Nagy Ádám 15 homogén csoportot azonosított (Nagy 2014a), Fekete-Prazsák négy kultúrafogyasztói csoportot (Fekete-Prazsák 2014), illetve Tóth-Huszár, akik a fiatalok foglalkozási szerkezetének átalakulását vizsgálták. Az elemzés szerint a fiatalok foglalkozási szerkezete kedvezőtlen irányba módosult, amit leginkább a polarizálódás irányával magyaráznak. Egyrészt nőtt a magasabb presztízsü foglalkozási csoportok súlya, de ugyanakkor növekedett alacsony vagy képzettséget nem igénylő munkát végzők aránya is (Tóth-Huszár 2016).

Az ezt követő négy évvel későbbi felmérés - Magyar Ifjúság Kutatás 2016 eredményei alapján Bokányi és társai a fiatalokat 6 klaszterbe csoportosították: magányosak, közélet iránt közömbös társaságiak, társasági műveltek, jólétben élő optimista aktívak, anyagilag deprivált optimisták, pesszimisták. Modelljüket úgy építették föl, hogy a hagyományos rétegképző változók helyett inkább a szubjektív kérdésekre koncentráltak: jövőbeli szubjektív kilátások, politikai aktivitás, társadalmi kapcsolatok helyzete és müveltség. A hagyományos rétegképzők közül az anyagi helyzetet vonták be az elemzésbe (Bokányi-Gyorgyovich-Pillók 2018). Egy másik - ezzel párhuzamosan megjelenő - elemzés azt a speciális „négydimenziós rétegződésmodellt” alkalmazza, amelyet Kabai Imre dolgozott ki az „Ifjúság 2000” adatbázisán. Korábbi empirikus eredményeikre hivatkozva ismét megállapítják, hogy a 
posztmodern világban élő fiatalok helyzetét - a klasszikus rétegképző tényezőknél erősebben - az életútjuk alakulása határozza meg (Kabai-Iharosi-Kabainé Tóth 2018).

\subsection{Kísérletek az erdélyi magyar fiatalok társadalmi helyzetének leírására}

Romániában a kilencvenes évektől a román és a magyar ifjúságkutatásokat egyfajta párhuzamosság jellemezte, az erdélyi magyar kutatásokat elsősorban a magyarországi ifjúságszociológia inspirálta. A kutatások közpolitikai indíttatása szinte teljes mértékben hiányzott, és az elméleti beágyazottság szempontjából is különböző elméleti orientáltság jellemezte a magyar és a román kutatókat (Kiss-Barna 2011).

A román ifjúságkutatásban megjelenő összegzések elsősorban Schifirneț (1999) nevéhez füződnek. Mitulescu és Schifirneț szerint 1990-ig a romániai ifjúságkutatás erősen átpolitizált volt, a kutatási tematikákat inkább az határozta meg, hogy mit vártak el a fiataloktól, és nem az, hogy mik voltak a fiatalok igényei (Schiferneț 1999; Mitulescu 2011). A kilencvenes évek közeledtével már érezhető volt egyfajta változás, és 1994-ben illetve 1996-ban megjelentek a romániai ifjúságkutatások első nagyobb empirikus eredményei az alábbi tematikák mentén: munkaerő piaci integráció, oktatás, bünözés, elvándorlás, etnikumközi viszonyok, társas kapcsolatok (Mitulescu 2011; Ercsei 2015). 1996-tól kezdődően elindul a román ifjúságkutatás legjelentősebb kutatássorozata, az Ifjúsági Közvélemény-Barométer ${ }^{21}$, amely országos reprezentatív mintán vizsgálta a 15-29 éves korosztályt. Az ifjúsági barométer-vizsgálatok országos szinten egymást egy-két éves gyakorisággal követő adatfelvételek voltak, az alábbi témakörökben: életminőség, életszínvonal, élethelyzet, oktatás, munka és karrier, migráció, identitás, politikai kultúra, értékrend, életstílus és szabadidős tevékenységek. A barométer-adatfelvételek mellett számos további kutatás került megvalósításra a különböző témákban: vállalkozói magatartás, oktatás és munkaerőpiac, fiatalokat érintő kockázatok (kirekesztődés, marginalizáció), politikai kultúra, civil szervezeti

önkéntesség, IKT-használat (Ercsei 2017) További ifjúságkutatások az Életminőség

\footnotetext{
${ }^{21}$ Barometru de opinie - Tineret
} 
Kutató Intézet ${ }^{22}$ tevékenységéhez kapcsolódnak, viszont mindkét esetben kevés adat lelhetö fel. (Ercsei 2017)

2003-ban létrehozzák az ANSIT ${ }^{23}$ nevü intézetet, és ezt követően elkezdődik néhány együttmüködés a román-magyar ifjúságkutatásban. Az egyik ilyen együttmüködés a 2008-ban végzett Ifjúságkutatás ${ }^{24}$ volt, melynek eredményeként 2009-ben sor került egy ifjúsági konferenciára, ahol egyaránt részt vettek román, illetve magyar anyanyelvü ifjúságkutatók, majd egy tanulmánykötet is megjelent, román és magyar nyelven.

Erdélyben a rendszerváltást követően az első, kifejezetten a magyar fiatalokat célzó nagymintás kutatás a MOZAIK 2001. Ezt követően, 2005-ben jelent meg a Perifériáról a centrumba címü tanulmánykötet, melynek középpontjában a rendszerváltás fiatalokra kifejtett hatásai állnak. A kötetben több olyan elemzés is van, amely az erdélyi magyar fiatalok helyzetének értelmezésekor az ifjúsági korszakváltás két forgatókönyvének a megvalósulási esélyeit vizsgálja: a munkanélküliségi, illetve szabadidős szcenárió bekövetkeztét, dominanciáját (Csata 2005; Gábor 2005; Veres 2005). A romániai rendszerváltás és az európai uniós csatlakozási folyamat keretei között az ifjúsági korszakváltás valamivel később, az 1990-es évek második felében indult be, aminek társadalmi hatásaként kialakulóban van egy új, fiatal középosztály, de a folyamat kiteljesedése még 2006-ban is zajlott (Veres 2006).

Veres (2005) azt vizsgálja, hogy hogyan tükröződik az ifjúsági korszakváltás az életesemények tervezésében, hogy az életszakaszok közötti átmenet mennyire rétegfüggő, illetve a rétegfüggőség mennyire van összefüggésben az etnikai hovatartozással. Következtetése szerint a fiatalok jövőtervezését a régió általános társadalmi-gazdasági helyzete és a réteghelyzet határozza meg. A jobb helyzetben levő régiók fiataljai körében megfigyelhetjük az iskolai ifjúsági életszakasz meghosszabbodását és az oktatás expanzióját, mely változások elősegítik a „második demográfiai átmenet” hátterét képező posztmateriális értékrend elterjedését. Ugyanakkor a származási háttér is jelentősen befolyásolja a jövőtervezést. Zinnecker osztályhabitusaihoz kapcsolódva

\footnotetext{
22 Institutul de Cercetare a Calității Vieții ICCV

${ }^{23}$ Agențtia Națională pentru Sprijinirea Inițiativelor Tinerilor/Országos Hatóság az Ifjúsági Kezdeményezések Támogatásáért

${ }^{24}$ A kutatást 2008 szeptemberében az Országos Ifjúsági Hatóság (ANT-ANSIT) kezdeményezte, és a kolozsvári Nemzeti Kisebbségkutató Intézet (ISPMN) hajtotta végre.
} 
úgy véli, hogy a legjobb gazdasági és kulturális héttérrel rendelkező fiatalok a vállalkozói pályát, a kulturális osztályfrakciók a továbbtanulást választják (Veres 2005). Veres (2011) egy későbbi írásában a fiatalok sebezhetőségének osztályspecifikus mértékét vizsgálja. Hipotézisében a fiatalok társadalmi osztályhelyzet szerint más és más problémákat érzékelnek. A struktúra felső részéhez tartozó fiatalok, inkább a globalizációval járó problémákkal szembesülnek, míg a struktúra alsó részéhez tartozó fiatalok problémái pedig lokális jellegüek, inkább a leszakadás veszélye fenyegeti őket. A fiatalok sebezhetősége munkaerő-piaci vonatkozásban társadalmi héttértől független (Veres 2011).

A fiatalok rétegződésének egy másik fontos leágazása a Félsziget-kutatások ${ }^{25}$ kapcsán bontakozott ki, amelyet Gábor Kálmán Sziget-kutatásai ihlettek. Veres és Ercsei (2006) a Félsziget ifjúságának körében vizsgálják a fiatalok középosztályosodási tendenciát (Ercsei 2006; Veres 2006). Meglátásuk szerint olyan társadalmi folyamatok észlelhetők a romániai fiatalok körében, amelyek egy „kettős forgatókönyvü” ifjúsági korszakváltás bekövetkeztére utalnak: a munkanélküliségi forgatókönyvhöz a társadalom alatti osztály újratermelődését, míg a szabadidős forgatókönyvhöz a középosztályosodást társítják. Az erdélyi fiatalok esetében az ifjúsági korszakváltás erősebben osztályspecifikus, mint a magyarországi fiatalok esetében (Ercsei 2006; Veres 2006). Az erdélyi magyar fiatalok körében olyan kulturális és civilizatorikus tényezők hatnak (hagyományos női-férfi szerepek, vallásosság), amelyek lelassították az ifjúsági korszakváltás folyamatát (Gábor 2004). A kutatók úgy vélik, hogy az erdélyi magyar fiatalok körében a munkanélküliségi szcenárió és a szabadidő megnövekedésének szcenáriója egyszerre érvényesül, és kialakul az ifjúság „kettészakadt” társadalma, melyeket osztályspecifikusan értelmeznek (Ercsei 2006) (Gábor 2004). Minél magasabb társadalmi státussal rendelkezik a származási család, annál nagyobb esélye van a fiatalnak arra, hogy a szabadidős szcenárióját élhesse meg, illetve minél alacsonyabb társadalmi státussal rendelkezik a származási család, annál valószínübb, hogy

${ }^{25}$ A Félsziget-kutatás ötletét az évek óta megszervezésre kerülő Sziget-vizsgálat sorozata ihlette. 2005-től - 2013-ig, azaz kilenc éven keresztül zajlott kérdőíves adatfelvétel a Félsziget Fesztiválon, amelynek célja a fiatalok fogyasztói profiljának megrajzolása volt. Alapvetően a következő kérdésekre próbáltunk meg választ kapni: Milyen fogyasztói, illetve életstílus szerinti csoportok különböztethetők meg? Mi jellemző az egyes csoportok fogyasztói státusára/magatartására?

A Félsziget-kutatást a következő csapat vezette: Ercsei Kálmán, Kiss Zita, Plugor Réka, Szabó Júlia, Veres Valér. 
a munkanélküliség forgatókönyve fog érvényesülni. Ezen következtetések egybecsengenek Bourdieu és Zinnecker elméletével, miszerint az ifjúság a szülői társadalmi osztályhelyzet alapján szegmentálódik.

Veres egy későbbi tanulmányában szintén az „osztályok” jelenségét vizsgálja a romániai fiatalok körében. Központi kérdése, hogy a társadalmi háttér hogyan befolyásolja a kulturális és szabadidős tevékenységeket a fiatalok körében. A fiatalok társadalmi rétegződésének vizsgálatához fökomponens-elemzéssel egy státusindexet hoz létre, amely az anyagi és kulturális fogyasztás formáját és mértékét, illetve a munkakörülményeket tartalmazzák. Majd a fogyasztást mutató faktorértékeket kombinálja a foglalkozási státusszal. A népességet Bourdieu osztálysémája alapján közép- és alsó osztályba, felső- és alsó középosztályba sorolja, és különválasztja a társadalom osztálystruktúrájáról leszakadt réteget a depriváltakat. Az osztálystruktúrába történt besorolás szerint a 18-35 éves romániai fiatalok eloszlása a következő: a fiatalok 8,5 százalékát az elitbe, 15,4 százaléka a felsőközép osztályba, közel 45 százalékuk az alsóközép-osztályba sorolható, 17,4 százalék az alsó osztályt képezi és hasonlóképpen 17,4 százalék sorolható a depriváltak osztályába. (Veres 2017b) Az erdélyi magyarok körében hasonlók az értékek, 8,6 százalék a felső, 16,3 százalék a felső közép-, 37,3 százalék az alsó közép- és 21,1 százalék az alsó osztályhoz tartozik. A depriváltak aránya 16,6 százalék. Az erdélyi magyarok osztályhelyzete követi az országos trendeket, de a felső osztály nem koncentrálódik csupán a felsőfokú végzettekre (Veres 2011).

Ezt követően részletesen megvizsgálja a fiatalok kulturális fogyasztási mintázatait is, szintén faktoranalízis segítségével négy fogyasztói csoportot határoz meg: a screenagerek (22,9\%), a klubkultúra fogyasztók (16,2\%), a magas kultúra fogyasztók (13\%), otthoni irodalomolvasók (9\%) csoportja (Veres 2017b). Kissé eltérő struktúrában az erdélyi magyar fiatalok körében a kulturális fogyasztás tekintetében három csoport azonosít: a legfontosabb csoport továbbra is a screenagerek csoportja (20,5\%), majd a magaskultúra-fogyasztók (19,7\%), és klubkultúra fogyasztók (17,5\%). (Veres 2011)

Barna ugyanazokat az adatokat elemezve - hasonló módszerrel - a szabadidőskulturális tevékenységek típusát vizsgálva négy csoportot különböztet meg a román 
és a magyar fiatalok körében (Barna 2011). Az első faktort társaság vagy szórakozásorientált, a második faktort kultúraorientált, a harmadik faktort mozgásorientált, a negyedik faktor a médiaorientált szabadidős magatartás jellemez. Második lépésben azt vizsgálja, hogy milyen tényezők befolyásolják a szabadidős tevékenységeket, a regionális különbségeket is figyelembe véve. Az erdélyi magyar fiatalok valamivel kevésbé médiaorientáltak, mint az országos átlag, ritkábban néznek tévét, és ezen belül is a magyar fiatalok a legkevesebbet. A társaságorientált szabadidős tevékenységek leginkább az erdélyi románokra jellemzőek, a mozgáscentrikus időtöltés viszont a magyar fiatalokra. Az erdélyi fiatalok intenzívebben sportolnak és gyakrabban járnak kirándulni, mint az országos átlag. A kultúraorientált tevékenységek bár mindkét etnikum esetében a legkevésbé jellemző szabadidős magatartás, mégis eltérő intenzitású a romániai és az erdélyi magyar fiatalok között. A színházak és hangversenyek látogatottsága, ugyanakkor a mozi és a könnyüzenei koncertek látogatása is intenzívebb a magyar fiatalok körében (Barna 2011).

Mindkét elemzésben hangsúlyosan megjelenik a médiaorientált vagy más néven screeneger csoport, illetve a kultúrafogyasztói csoport. Veres (2017) a screenagerek csoportját emeli ki, rámutat, hogy a screenagerek életmódja Bourdieu-i értelemben a középosztály habitusának alkotóelemeivé vált, de azt is jelzi, hogy többfajta életmód is jellemezheti a középosztályt. A román fiatalok esetében a klub- és sport életmód már nem jellemző az alacsonyabb (munkás) osztályra, inkább a felső és középosztályokra. Következtetése szerint az életstílus nem kapcsolódhat kizárólag egy adott társadalmi osztályhoz, de a különböző kulturális és gazdasági erőforrások szintje függ a társadalmi osztály pozíciójától és ezek különböző a kulturális és szabadidős habitusokban nyilvánulnak meg. (Veres 2017b)

\section{5. Összefoglalás}

Az utóbbi években megjelent ifjúságszociológiai írások eredményeinek összefoglalásából azt láthatjuk, nincs egy egységes következtetés, hogy milyen változók mentén tudjuk leírni a fiatalok társadalmi hierarchiában elfoglalt helyét. Meglehetősen 
sokszínü térkép tárul elénk mind a magyarországi, mind pedig az erdélyi magyar fiatalok rétegződésről. Ez elsősorban a különböző elméleti megközelítések, de ugyanakkor az eltérő módszertani alkalmazásoknak is betudható.

Romániában a két nagymintás ifjúságkutatás között (2001-2016) jelentős gazdasági és társadalmi átalakulás volt, ami feltételezéseink szerint a társadalmi rétegződésben is átalakulásokat eredményezett. A szakirodalmi összefoglalásból kiderült, hogy a társadalmi rétegződés vizsgálatával foglalkozó kutatók körében időről időre felmerül az igény, hogy a rétegződéskutatást tágabban kellene értelmezni.

Elemzésünk is abból kérdésből indul ki, hogy ha az erdélyi magyar fiatalok rétegződését akarjuk leírni, akkor vajon erre elégséges a hagyományos paradigma, vagy más strukturáló tényezőket is be kell vonni az elemzésbe? Egy olyan többdimenziós tagozódási modell mellett érvelünk, amelyben a fogyasztásnak fontosabb stratifikációs jelentőséget tulajdonítunk. 


\section{A dolgozat kutatási kérdései}

Az elemzés célja, hogy bemutassa az erdélyi magyar fiatalok társadalmi struktúrában elfoglalt helyét. Az elméleti áttekintés során azt láthattuk, hogy az elmúlt évtízedben mind a struktúraelemzéssel kapcsolatban, mind pedig a fiatalok társadalomban elfoglalt helyéről szóló diskurzusban éles viták alakultak ki. A viták nagyrészét a két domináns paradigma, Bourdieu osztályalapú megközelítése (Bourdieu 1978b, 1984) és Beck (Beck 1999, 2004) paradigmaváltó diskurzusa robbantotta ki, mely szerint jelentős strukturális változások kezdődtek a modernizáció bekövetkeztével. A kutatások, felváltva használják hol az osztályszerkezeti, hol a rétegződési megközelítések fogalmait, és arra keresik a választ, hogy vajon az életstílus- és miliőkutatások tekinthetők-e az osztály- és rétegződésmodellek alternatívájának.

Elemzésünk során azt vizsgáljuk, hogy vajon elégséges-e a „hagyományos” szemléletmód, mely alapvetően a vertikális tagoltságra korlátozódik (Bourdieu 1978a, 1978b; Erikson-Goldthorpe-Portocarero 1988; Huszár 2012; Tóth-Huszár 2016), vagy más - újszerübb, modernebb - tényezöket is érdemes bevonnunk az elemzésünkbe, mint például a szabadiős/kulturális fogyasztás (Csite-Kovács-Kristóf 2006; Kovách-Kuczi-Jókuthy 2006; Savage et al. 2013; Fekete-Prazsák 2014).

Ezen tényezők kiválasztásánál osztozunk azon aggályokon, melyeket Angelusz Róbert fogalmaz meg, és a „láthatóság görbe tükreiként” nevez meg (Angelusz 2000). Az Angelusz-féle metafora plasztikusan hívja fel a figyelmet a társadalmi látásviszonyok romlására, a társadalmi nagycsoportok csökkenő áttekinthetőségére, ezen csoportok átalakulására, eltűnésére.

Csatlakozva a „látásviszonyok” romlásának a tényéhez, úgy gondoljuk, hogy napjainkban a társadalmi differenciálódás egy többdimenziós - több-komponensü jelenség, következésképp szélesebb vizsgálatot igényel. Azt gondoljuk, hogy a klaszszikus anyagi- és foglalkozás-szerkezeti jellemzőkön kívül - különösen az általunk vizsgált fiatalok esetében - fontos olyan jellemzőket is bevonni az elemzés folyamatába, melyek a kulturális fogyasztói habitusok vizsgálatára vonatkoznak.

Kutatási kérdéseink az elméleti diskurzusokban észlelhető fentebb bemutatott dilemmából indultak ki, és kezdetben a következő formában fogalmazódtak meg: 
1. Melyik rétegződéselméleti megközelítés írja le a legjobban a fiatalok társadalmi tagolódását?

2. Milyen tényezők mentén magyarázható meg a fiatalok társadalmi rétegződése?

3. A fiatalok társadalmi rétegződését leíró tényezők között van-e domináns tényező vagy több tényező is felelős?

Úgy gondoljuk, hogy a fiatalok társadalmi tagolódásában is fontos kérdés, hogy mennyire a hagyományos - vertikális - tényezők (értjük alatta a foglalkozást, és a szüken értelmezett foglalkozási osztálykoncepciót, az iskolai végzettséget és a jövedelmet) és mennyire a „szoft” - horizontális - tényezők (életmód, fogyasztás, nem, életkor) szegmentálnak.

Elemzésünk az erdélyi magyar fiatalok szocio-demográfiai jellemzőinek bemutatását követően alapvetően két részre tagolódik. Az első részben (7. fejezet) a státushelyzet társadalmi meghatározóit vizsgáljuk a MOZAIK 2001 és a Magyar Ifjúság Kutatás 2016 felmérések alapján. Azt vizsgáljuk meg, hogy a fiatalok státushelyzete hogyan függ össze különböző szociodemográfiai jellemzőkkel.

A fiatalok rétegződésének leírására egy összetett mutatót hoztunk létre, státusindexet szerkesztettünk, az alábbi három dimenzió mentén: lakáskörülmények (lakás négyzetmétere, infrastruktúrája), anyagi vagyoni helyzet (tartós/használati cikkek), szabadidős fogyasztás (az elmúlt egy évben utazott-e turisztikai céllal más országban, hány könyvet olvasott, szabadidős tevékenységek). Továbbá azt vizsgáljuk, hogy az alábbi független változók hogyan magyarázzák a státushelyzetet:

- Nem, életkor

- Iskolázottság (általános iskola/szakiskola; elméleti líceum/föiskola; egyetemi végzettség)

- Település típusa (megyeszékhely, más város, falu)

- Apa iskolai végzettsége, apa foglalkozása

- A megkérdezett foglalkozási státusa (tanul, dolgozik vagy egyik sem)

A horizontális (fogyasztásbeli) eltérések figyelembe vétele (Fábián-RóbertSzívós 1998) a gyakorlatban azt jelenti, hogy a szabadidő felhasználásának módja is meghatározza a fiatalok társadalmi szerkezetben elfoglalt helyét. A Státushelyzet társadalmi meghatározói fejezethez kapcsolódó kutatási kérdéseink:

(1) Hogyan magyarázzák a státushelyzetet a különböző szocio-demográfiai jellemzők (nem, életkor, településtípus)? 
(2) Milyen hatással van a fiatalok státusára a származás (apa iskolai végzettsége, foglalkozása)

Az elemzés második (8. fejezet) részében a fiatalok kulturális szegmentációjára fókuszálunk. Ez a fejezet tulajdonképpen az első fejezet további árnyalásáról szól, kulcskérdésünk, hogy milyen mértékü a vertikális és a horizontális rétegképző változók között az összefüggés. Korábbi rétegződés-vizsgálatokból (Fábián-Kolosi-Róbert 2000; Savage et al. 2013) az derült ki, hogy az egyenlőtlenségi rendszert nagymértékben meghatározzák a kulturális jellegű társadalmi különbségek is, ezért tartjuk indokoltnak a kulturális fogyasztás kiemelt vizsgálatát.

Az elemzés során a GeneZYs 2015 adatait használtuk fel, mert ez a felmérés vizsgálta a legrészletesebben a fiatalok szabadidős fogyasztását. Klaszteranalízis segítségével határoztuk meg a tipikus kulturális fogyasztói szegmenseket, és ezt követően ezeket a csoportokat tettük a vizsgálat tárgyává. A Kulturális szegmentáció az erdélyi magyar fiatalok körében fejezethez kapcsolódó kutatási kérdéseink:

(1) Milyen kulturális fogyasztásbeli jellegzetességek alapján különülnek el az erdélyi magyar fiatalok?

(2) Milyen tényezők befolyásolják a kulturális fogyasztási szokásaikat, a különböző fogyasztói csoportokba való tartozást?

(3) Mennyire érvényes az erdélyi magyar fiatalok körében az a megközelítés, mely szerint a „kulturális mindenevőség” felbukkanása feloszlatja az osztályalapú megkülönböztetést a kulturális fogyasztás tekintetében? 


\section{A dolgozatban használt adatok bemutatása}

\subsection{Bevezetés}

Az ezredfordulót követően számos ifjúságszociológiai felmérés zajlott Erdélyben, az első ilyen nagyméretű felmérés a MOZAIK 2001. További nagyobb mérföldkő az ifjúságszociológiai kutatásban a kolozsvári Nemzeti Kisebbségkutató Intézet 2008-as felmérése az erdélyi magyar fiatalok körében, mely részben a 2001-es kutatással való összehasonlítás, részben pedig a magyar és a román fiatalok közötti különbözőségek feltárásának céljával készült. Ezt követően 2013 áprilisában a Kós Károly Akadémia Alapítvány és az Európai Tanulmányok Központ (Centre for European Studies CES) felkérésére készült egy hasonló felmérés. Majd 2015-ben zajlott a GeneZYs Kárpát-medencei ifjúságszociológiai felmérés MCC, MTA TK Kisebbségkutató Intézet és az Információs Társadalomért Alapítvány együttmüködésében, illetve a legutóbbi Magyar Ifjúság Kutatás 2016, ami az Új Nemzedék Központ megrendelésére készült.

A MOZAIK 2001, a GeneZYs 2015, illetve a Magyar Ifjúság Kutatás 2016-os felmérések a Kárpát-medence magyar régióira (Erdély, Felvidék, Vajdaság és Kárpátalja), 15-29 éves fiatalokra vonatkozó reprezentatív kérdőíves kutatások. A kutatási kérdéseink megválaszolásához, ezen három nagymintás ifjúságkutatás adatait használjuk fel.

\subsection{MOZAIK 2001. Magyar Fiatalok a Kárpát-medencében}

A MOZAIK 2001 Magyar Fiatalok a Kárpát-medencében címü kutatás a Magyarországon végzett „Ifjúság 2000” elnevezésű kutatás folytatása határon túli magyarlakta területeken, 6480 fős mintán, survey módszerrel. A felmérést a Nemzeti 
Ifjúságkutató Intézet által felkért kutatók, valamint erdélyi, szlovákiai, vajdasági és kárpátaljai magyar társadalomkutatók munkacsoportja végezte. Mintaelemszám: Belső Erdélyben 1200, Székelyföldön 750, azaz összesen 1950 15-29 év közötti magyar fiatal.

A kérdőíves vizsgálat kivitelezését a különböző régiókban egyes partnerintézetek vállalták, Belső-Erdély és Partium esetében a Max Weber Társadalomkutatásért Alapítvány és a Babeş-Bolyai Tudományegyetem Szociológia Tanszéke (1196 magyar, 724 román $\left.{ }^{26}\right)$, a székelyföldi alpopulációt a KAM (750 magyar) mérte fel. A mintavételi és a lekérdezési eljárás is két síkon zajlott. (Részletesebben lásd. Melléklet.10.2.1)

A kutatás célja az volt, hogy átfogó képet adjon a határon túli magyar fiatalok anyagi és kulturális erőforrásairól, életmódjáról. A kérdőív kidolgozásánál a kutatók az Ifjúság 2000 magyarországi felmérést vették alapul, ami 170 kérdést tartalmazott ezt terjedelme miatt nem csatolunk a mellékletben sem - az alábbi témakörökben. ${ }^{27}$

1. Társadalmi mobilitás

- Család kulturális tőkéje, szülők iskolai végzettsége, foglalkozása

2. Iskolai életút

- Iskolai végzettség, jelenlegi iskolai helyzet, továbbtanulási tervek

3. Egzisztenciális helyzet

- Tartós fogyasztási eszközök, jövedelem, gazdálkodás, lakáshelyzet

4. Családi helyzet

- Együttélés a szülőkkel és a testvérekkel, párkapcsolatok, elköltözés

5. Munkaerőpiaci jellemzők

- Első munkába állás, jelenlegi és korábbi munkahelyek, munkavállalási tervek

6. Társadalmi közérzet, közéleti attitüdök

- Társadalmi problémák megítélése, politikához való viszony, szervezeti aktivitás

7. Egészség, életmód

\footnotetext{
${ }^{26}$ A román nyelvű fiatalok vizsgálatára nem térünk ki dolgozatunkban, elsősorban azért, mert a Magyar Ifjúság 2016-os kutatásban nem kérdeztek román anyanyelvü fiatalokat, így nincs lehetőségünk az összehasonlításra.

${ }^{27}$ Forrás: Szabó, A. - Bauer, B. - Laki, L. - Nemeskéri, I. (szerk.) MOZAIK 2001. Gyorsjelentés. Magyar fiatalok a Kárpát medencében. Budapest: Nemzeti Ifjúságkutató Intézet, 13 old.
} 
- Egészségi állapot, életmód jellemzői, alkohol- és drogfogyasztás

8. Sporthoz való viszony

- Sportolási szokások, sportágak népszerüsége, sportmüsorok nézettsége

9. Értékrend, vallásosság

- Vallásosság, felekezeti hovatartozás, általános értékrend, szülői értékrendhez való viszony, különböző társadalmi, nemzetiségi és ifjúsági kulturális csoportokkal szembeni elöítéletesség

10. Kulturális fogyasztás - szabadidő

- Médiafogyasztás, kulturálódási-művelődési szokások

11. Informatikai ismeretek

- Számítógép-használati szokások, informatikai ismeretek

12. Nemzeti identitás

- Nemzeti identitás, anyaországhoz való viszony jellemzői, összetevői

13. Magyarországi munkavállalás

- Magyarországi és egyéb külföldi munkavállalási tapasztalatok, tervek

14. NATO-hoz, Európai Unióhoz való viszony

- Csatlakozással szembeni elvárások

15. Magyarországi turizmus

- Magyarországra irányuló utazások, magyarországi itt-tartózkodás vizsgálata

\subsection{GeneZys 2015}

A felmérést a Mathias Corvinus Collegium (MCC), a Magyar Tudományos Akadémia Társadalomtudományi Kutatóközpont Kisebbségkutató Intézete (MTA TK KI) és az Információs Társadalomért Alapítvány INFOTA Kutatóintézete végezte 2015-ben, a 15-29 éves magyar anyanyelvü fiatalok körében. A minta végső összeállítását, a lekérdezés és adatrögzítés koordinálását a Kvantum Research Kft. végezte. (Részletesebben lásd. Melléklet.10.2.2)

A felmérés 2700 (1000 erdélyi, 700 felvidéki, 500 vajdasági és 500 kárpátaljai) külhoni magyar fiatal megkérdezésével készült reprezentatív kárpát-medencei 
ifjúságszociológiai kutatás: korra, nemre, településtípusra, és régiókon belül területi megoszlás szerint. A kérdőívben 123 kérdés szerepelt, az alábbi tematikus blokkok szerint:

1. Oktatás

- Oktatási részvétel, iskolai végzettség, továbbtanulás, különórák

2. Társadalmi mobilitás

- Szülök iskolai végzettsége, foglalkozása

3. Munkaerő-piaci állapot

- Jelenlegi foglalkozás, élettárs-házastárs foglalkozása

4. Család

- Családi állapot, gyerekvállalási hajlandóság

5. Értékvilág, vallásosság

- Vallásosság, felekezeti hovatartozás, az ifjúság legégetőbb problémái, társadalmi csoportokkal szembeni elöítéletesség

6. Életmód, szabadidő

- Időhasználat, kulturális fogyasztás, feszültségoldó szerek használata

7. Médiahasználat, digitális tájkép

- Médiafogyasztási szokások (rádió, tévé, nyomtatott újság, online portálok), internethasználat, közösségi oldalak

8. Etnikai, nemzeti identitás szerkezete

- Nyelvhasználat és színterei, haza fogalma, kettős állampolgárság igénylése és hatása, identitás

9. Társadalmi közérzet, politikai részvétel, migráció

- Szervezeti tagság, társadalmi problémák megítélése, külföldi tartózkodás, kivándorlás és ennek okai

10. Anyagi helyzet

- Tartós fogyasztási eszközök, jövedelem, lakáshelyzet, szubjektív jólét

\subsection{Magyar Ifjúság Kutatás 2016}

A Magyar Ifjúság Kutatás 2016 a korábbi nagymintás ifjúságkutatások (Ifjúság 2000-2008; MOZAIK 2001-2011, Magyar Ifjúság 2012) által kijelölt irányvonalak 
mentén készült. Mintaelemszám: 2000 15-29 év közötti magyar fiatal (Partium, BelsőErdély 1000 fö és Székelyföld 1000 fö)

A kérdőíves vizsgálat kivitelezését Erdélyben szintén a Max Weber Társadalomkutatásért Alapítvány és a Babeş-Bolyai Tudományegyetem Szociológia Tanszéke végezte, ezúttal mindhárom régióban, Belső Erdélyben, Partiumban, illetve Székelyföldön egyaránt ${ }^{28}$. (Részletesebben lásd. Melléklet.10.2.3)

A kérdőív főbb témakörei a 2001-es MOZAIK felmérés kérdéseiből indultak ki, de inkább a 2016-os magyarországi felmérés kérdéseihez igazodtak.

1. Család, gyerekvállalás

- Családi állapot, gyerekvállalási hajlandóság, élettársi kapcsolatok, család szerepe az életben, életesemények

2. Oktatás

- Iskolai végzettség, foglalkozás, továbbtanulás, oktatás nyelve, külföldi tanulmányok, idegen nyelv ismerete

3. Identitás

- Nemzeti-etnikai attitüdök, haza, nyelvhasználat különböző helyeken (családban, barátokkal, munkahelyen, orvosnál, olvasás stb.)

4. Munkaeröpiac

- Iskola melletti munka, első munkahely, utolsó foglalkozás, munkanélküliség, elhelyezkedési lehetőségek és nehézségek, külföldi munka és tanulás

5. Társadalomhoz való kapcsolódás, közélet

- Etnikai sokszínűség iránti attitüd, társadalmi problémák megítélése, politikához való viszony, szervezeti tagság, szülők elveivel való egyetértés, az ifjúság legégetőbb problémái, elégedettség-bizalom

6. Média, kommunikáció

- Digitális eszközök, internethasználat, médiafogyasztási szokások (rádió, tévé, nyomtatott újság, online hírportálok, közösségi oldalak), információforrások fontossága

7. Sport, szabadidő

\footnotetext{
${ }^{28}$ Mind a szakmai előkészítésben mind pedig a lekérdezés koordinálásában részt vettem.
} 
- Egészséges életmód, sportolási szokások, nyaralási szokások, szabadidő-eltöltési szokások, kulturális fogyasztás, fesztiválokon való részvétel, zenei ízlés, személyes kapcsolatok

8. Önkitöltős rész

- Politikai attitüdre vonatkozó kérdések, szavazási hajlandóság, pártszimpátia, állampolgárság, drog- és alkoholfogyasztás

9. Értékrend

- Társadalmi csoportokkal szembeni előítéletesség, értékvilág, termékekkel kapcsolatos attitüdök (magyar versus román termékek)

10. Vallás

- Felekezeti hovatartozás, vallásosság, vallási szertartások fontossága

11. Lakáshelyzet, életkörülmények

- Lakáskörülmények, hányan élnek egy háztartásban, családi és egyéni jövedelem, szubjektív jólét

12. Társadalmi mobilitás

- Szülök iskolai végzettsége, foglalkozása

\section{5. Összefoglalás}

Mindhárom felmérés, a MOZAIK 2001, a GeneZys 2015, a Magyar Ifjúság Kutatás 2016 rétegzett véletlen mintavételi eljárást alkalmazott, kombinálva a kvótássétálós módszerrel.

Erdélyben az ezredforduló óta a mintavételi eljárás során - a léptékes módszer, véletlen séta alkalmazásával - a település és a kiválasztott személy közötti szintre, a háztartásra összpontosítottak, és ennek kiválasztási módját finomították. Ez azt jelenti, hogy a többségi magyarlakta településeken lépték (és a háztartáson belül kvóta), a szórványterületeken pedig kvóta szerint kérdeztek. A háztartásokon belüli kiválasztás is a kvóták segítségével történt. A léptékes, más szóval „,véletlen sétás” módszer elméletileg megfelel a véletlen kiválasztás szabályainak, tehát ezen vizsgálatok léptékes almintája reprezentatívnak tekinthető. A módszert több országban (elsősorban az 
Egyesült Államokban, Dél-Amerikában) is alkalmazzák, bár főleg akkor, ha jogi okból nem lehet címlistát szerezni. (Kiss-Kapitány 2009)

Mindhárom felmérés célcsoportja a 15-29 éves korosztály, és a kutatások adatai régiókra, életkorra, nemre és településtípusra is reprezentatív információkat biztosítanak.

A MOZAIK 2001 és a Magyar Ifjúság Kutatás 2016 két fő részből állt, a magyarországi fiatalok élethelyzetét és életmódját vizsgáló kutatásból és a határon túli magyar fiatalokról szóló kutatásból, amelyek azonos tematika mentén készültek.

A fentebb említett kutatások nem kimondottan struktúrakutatás céljával készültek, ezért az elemzés során néhány módszertani korláttal kellett számolnunk. Egy másik nehézség volt, hogy a 2016-os kutatás tervezésekor a kutatók a magyarországi kérdőívet kezelték alapként, így a MOZAIK 2001-es kutatással való összevethetőség lehetősége csökkent.

A MOZAIK 2001, illetve a Magyar Ifjúság Kutatás 2016-os kutatások mentén írjuk le a fiatalok társadalmi szerkezetében (iskolai végzettség, foglalkozási szerkezet, anyagi helyzet) bekövetkezett változásokat, valamint a fiatalok státushelyzetének társadalmi meghatározót.

A fiatalok kulturális szegmentációjának leírásához a GeneZYs 2015-ös felmérés adatait használtuk. Elemzésünkhöz azért választottuk ezt az adatbázis, mert ez a felmérés vizsgálta a legrészletesebben a fiatalok szabadidős fogyasztását. (Lásd. Melléklet 10.3.2.) 


\section{Az erdélyi magyar fiatalok szocio-demográfiai jellemzői 2001 és 2016 között}

\subsection{Bevezetés}

A fejezet célja, hogy a föbb szocio-demográfiai változók mentén leírást adjunk a 15-29 év közötti fiatal populációról, részben a népszámlálási adatok, részben pedig az említett felmérések adatai alapján. A fiatalok demográfiai jellemzőinek leírásához két nagymintás ifjúságkutatás adatait - a MOZAIK 2001, illetve a Magyar Ifjúság Kutatás 2016 - használjuk fel.

\subsection{Demográfiai helyzetkép}

Románia állandó lakossága - a 2011-es népszámlálási adatok szerint - a 2002es népszámláláshoz viszonyítva 12,2 százalékot csökkent. A városokban a népességcsökkenés jóval nagyobb mértékü volt, mint falun, 15, illetve 8 százalék. Legkisebb csökkenés Temes (-4,2\%), Kolozs (-6,2\%), Hargita (-6,5\%), és Kovászna (-7,3\%) megyékben volt (Kiss-Barna 2012).

A magyar népesség fogyása a román populációnál is jelentősebb: 2011-ben 13,6 százalékos volt, a csökkenés Románia szintjén, ez abszolút értékben 194 ezer, Erdélyben pedig 190 ezer (Kiss-Barna 2012). Ezen belül a legnagyobb csökkenés 15-29 évesek körében észlelhető, 2002 és 2011 között 50 százalékkal csökkent a magyar fiatalok számaránya, ami 99 ezer fiatallal jelent kevesebbet. Megyék szerint a csökkenés mértéke a magyar lakosság körében: Krassó-Szörény, Hunyad és Temes megyékben a legnagyobb, míg a legkisebb mértékü fogyást Hargita és Kovászna megyékben regisztráltak. 
6.1. ábra: Az erdélyi magyar fiatalok számának alakulása 2002-2011 között. Forrás: Népszámlálási adatok 2002-2011; Román Statisztikai Hivatal (saját szerkesztés).

Magyar fiatalok számának változása 2002-2015 között

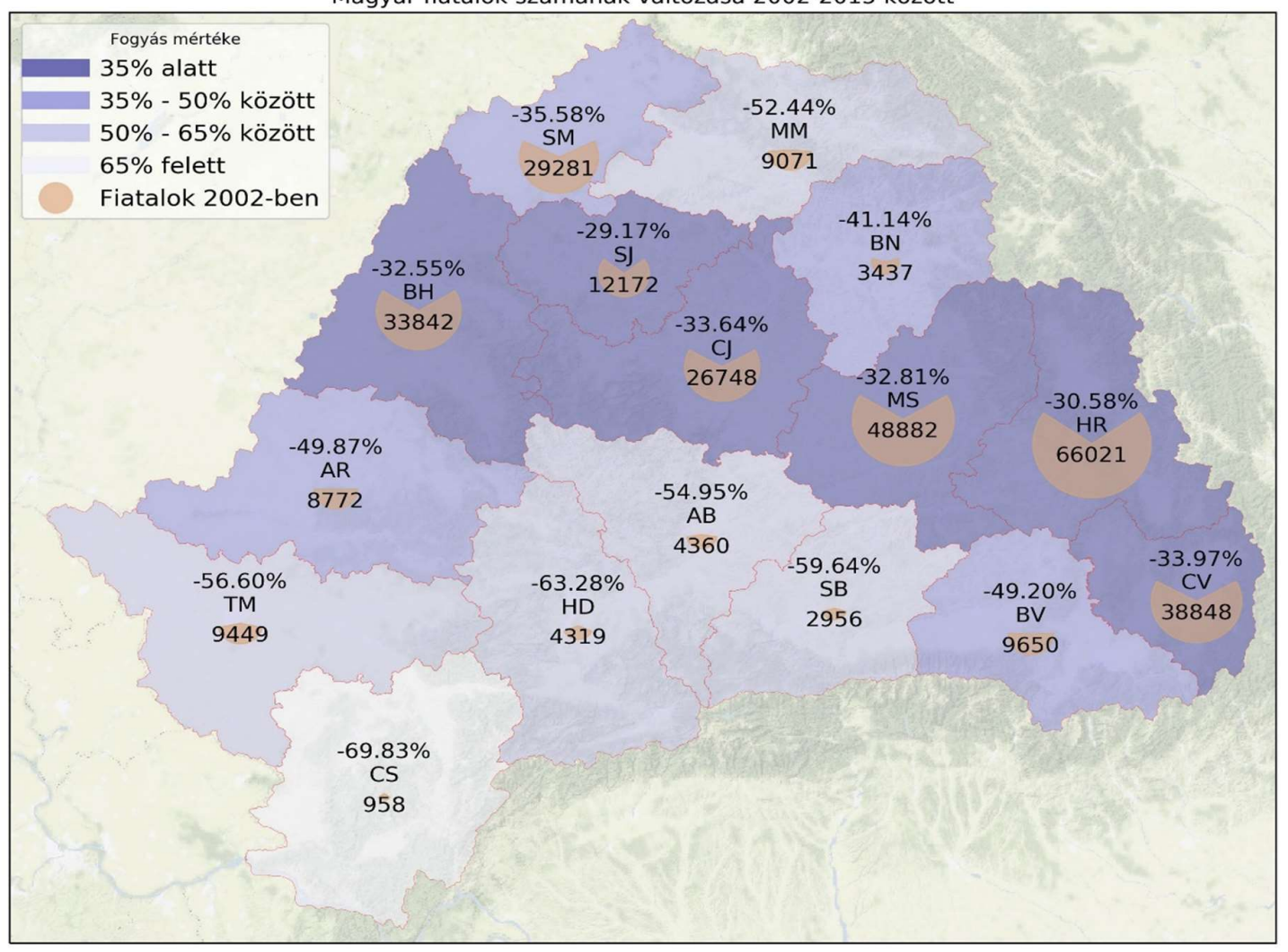



bontásban. Forrás: Népszámlálási adatok 2002-2011; Román Statisztikai Hivatal (saját szerkesztés)

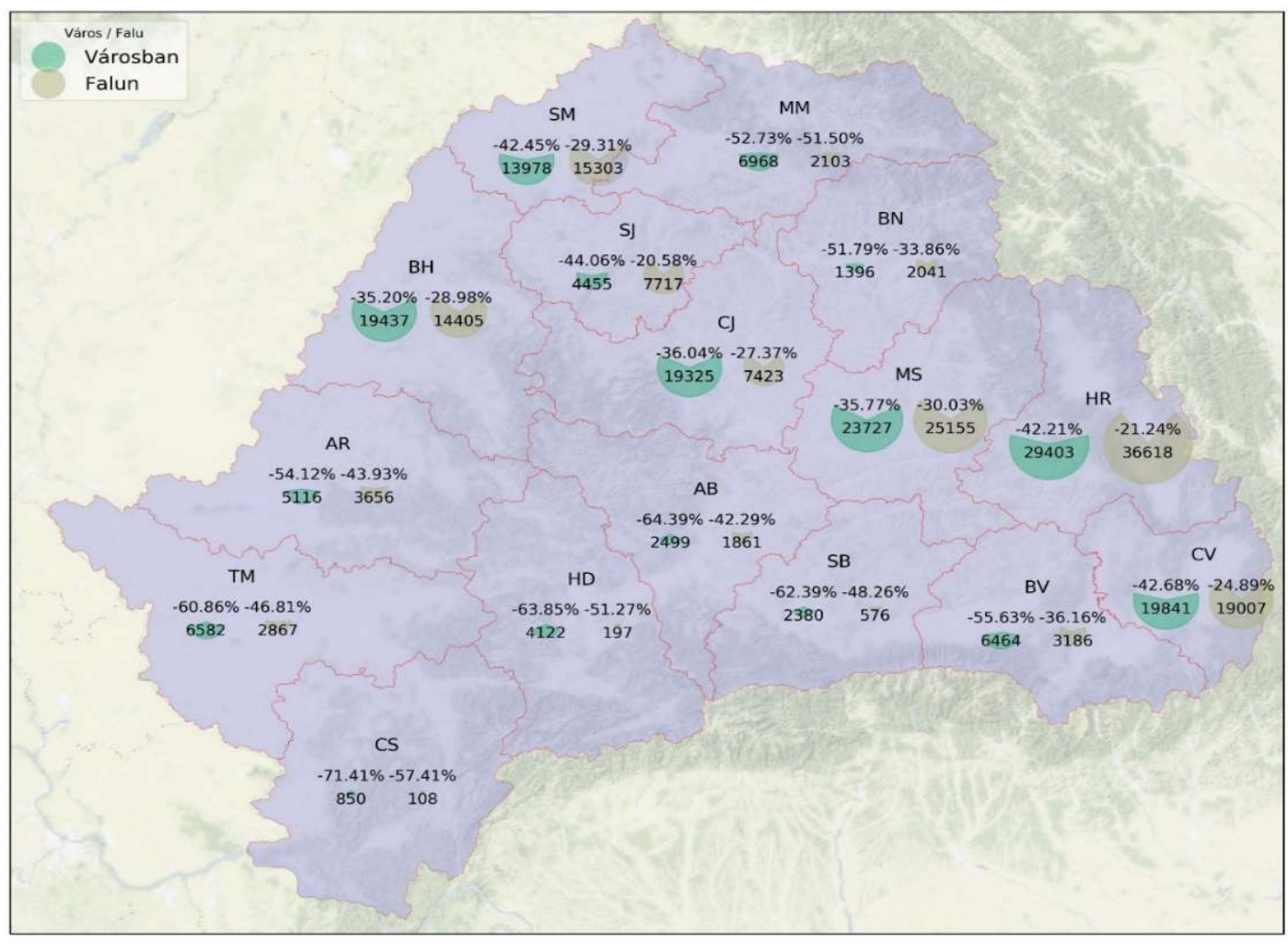

A népességfogyás sem regionálisan, sem települések típusa szerint nem egyenletes, jelentősen csökkent Erdélyben és általában a nagyvárosokban élő magyar fiatalok aránya (Barna-Kiss 2013). Amennyiben településtípusok, illetve megyék szerint nézzük a fiatalok arányát, azt látjuk, hogy minél alacsonyabb egy adott megyében a magyar fiatalok aránya, annál jelentősebb a fiatalok számbeli csökkenése. Megyék szerint Krassó-Szörény, Hunyad, Szeben és Fehér megyékben a legjelentősebb a csökkenés, a legkisebb pedig Hargita, Kolozs, Szilágy és Bihar megyében. Hosszabb távon ez azt fogja jelenteni, hogy a fiatalok egyre nagyobb hányada fog magyar tömbvidéken élni, a szórványterületek a vártnál gyorsabban „felszámolódnak” (Kiss-Barna 2012), ami azt is maga után vonja, hogy az erdélyi magyar közösségen belüli tömbterületek súlya felértékelődik.

2002 és 2011 között a községek szintjén a magyar lakosság körében 7,4 százalékos, a nagyvárosokban pedig 23,1 százalékos volt a fogyás (Kiss-Barna 2012). A 
legkisebb mértékü fogyás Szilágy, Hargita és Kovászna megyékben észlelhető. A fiataloknál is visszatükröződik az, hogy a városokban nagyobb arányú a fogyás, mint a falvakban, ez viszont csak részben jelenti a szuburbanizációs folyamatok felerősödését, ami a városi lakosság kitelepedését jelenti a környező falvakba.

A magyarság, és ezen belül a fiatalok arányának csökkenése az 1990 és 2011 közötti időszakban kismértékben tulajdonítható a belső vándorlási folyamatoknak, inkább a magyarság elöregedettebb korösszetételére utal, és az 1988 és 2000 közötti, viszonylag jelentős Magyarországra irányuló kivándorlásra vezethető vissza (amely aztán a magyarok termékenységében is visszatükröződött az elvándoroltak „hiányzó gyermekei” által) (Veres 2018). Ugyanakkor a 2002 és 2011 közötti csökkenést is elsősorban a migrációs veszteség okozta, a korábbi 1992-2002 közötti periódushoz viszonyítva nagyobb arányú volt a magyarok elvándorlása (Kiss-Barna 2012). Egy másik tényező, ami szintén befolyásolta a magyar fiatalok arányának alakulását, hogy a nagyobb városokban erősebb az asszimiláció, azért kevesebb magyar születik és nő fel városon.

Az erdélyi magyar népesség a 2011-es népszámlálási adatok szerint 51 százaléka városon és 49 százaléka falusi településen él. Korcsoportok szerint a 15-29 éves fiatalok 28 százaléka 15-19 éves, 36 százaléka 20-24, 35 százaléka pedig 25-29 éves. ${ }^{29}$ Azt látjuk tehát, hogy a magyar népesség korfája Székelyföldön a legfiatalabb, vagyis a legtöbb magyar fiatal Hargita, Maros, Kovászna, Bihar és Kolozs megyében él.

A szocio-demográfiai adatokat elemezve szembetűnő változás van a családi állapot tekintetében, egyrészt azt láthatjuk, hogy az élettársi kapcsolatban élők száma 2,8 százalékról 8,7 százalékra emelkedett, másrészt 2001-hez képest a házas fiatalok kisebb arányban vannak jelen, 2016-ban 10 százalékponttal kevesebb a házasságban élők száma. (Lásd. Melléklet 10.1. táblázat.) A házasságkötéssel és válással kapcsolatos szokások megváltozására Veres (2015) és Vita (2014) is rámutatnak. A rendszerváltás után, 1990-ben Romániában 8 ezrelék fölötti volt a bruttó házasságkötési arányszám, amely ezt követően lassan csökkent az évtized végére 6 ezrelék alá, aztán 2002-től elkezdett kis mértékben növekedni. 2008-ban 6,9 ezrelékre emelkedett, de

\footnotetext{
${ }^{29}$ Forrás: A 2011. évi népszámlálás végleges eredményei. A százalékok a szerző számításai.
} 
újra elkezdett csökkenni, 2010-től már 5 ezrelék körül mozog (Veres 2015). A házasságkötéssel kapcsolatos magatartás változásának egyik fontos összetevője az átlagéletkor kitolódása az első házasságkötéskor, az ezredfordulót követően a nők átlagéletkora 22 évről 27-re, a férfiaké pedig 25 évről 30-ra emelkedett (Veres 2015). Egy másik fontos összetevő az alternatív együttélési formák elterjedése, valamit az egyedülálló, egyszemélyes háztartások számának növekedése (Vita 2014).

A fiatal népesség szocio-demográfiai összetétele a két felmérésben (MOZAIK 2001 és Magyar Ifjúság Kutatás 2016) nem, korcsoport és településszerkezet tekintetében alapvetően hasonló, csupán néhány elenyésző eltérés van. ${ }^{30}$

\subsection{Iskolai végzettség}

$\mathrm{Az}$ iskolai végzettséget vizsgálva, az egyik leglátványosabb változás, hogy 2016-ban közel kétszer annyi fiatalnak van egyetemi végzettsége, mint 2001-ben (lásd. Melléklet. 10.1. táblázat). Romániában a felsőoktatás expanziója az ezredforduló után kezdett el kibontakozni, már a 2002. és a 2011. évi népszámlálási adatok is mutatják, hogy jelentősen növekedett a felsőoktatásban részt vevők aránya a beiskolázott népességben. 1992-ben csupán 5-6 százalékot tettek ki, 2002-ben 14,4 százalékot, 2011-ben már a népesség 19,8 százaléka tanult felsőfokú intézményben (Veres 2014, 2015) (Salat et al. 2010). A magyar nemzetiségü népesség körében a felsőfokú végzetséggel rendelkezők aránya 2011-ben mindössze 10,2 százalék, viszont a 2002es iskolázottsági helyzethez viszonyítva ez is jelentős növekedésnek tekinthető, hiszen akkor a magyarok csupán 5 százalékának volt felsőfokú végzettsége, tehát az országos átlaghoz hasonlóan megduplázódott a felsőfokú végzettek száma (Veres 2015). A „képzési olló” kiegyenlítődése ${ }^{31}$ már 2002-ben megfigyelhető volt a felsőfokú képzésben részt vevők számának lényeges megnövekedésével (Salat et al. 2010).

${ }^{30}$ A 2016-os mintához képest 2001-ben a városi fiatalok vannak felülreprezentálva. A MOZAIK 2001-es felmérésben a megkérdezett fiatalok 67 százaléka élt városon, 2016-ban pedig 49 százaléka. Ez főleg a településszerkezeti átalakulásoknak tudható be, az erdélyi városok összetétele megváltozott, egyrészt a népességfogyásnak köszönhetően, másrészt pedig a belső vándorlás (város-falu) hatására. A 2001 és a 2016-os felmérés korösszetétele hasonló, 2001-ben valamivel több 20-24 éves került a mintába, ami annak tudható be, hogy 2001-ben Belső-Erdélyben és Székelyföldön két különböző mintavétel szerint zajlott a lekérdezés, és a székelyföldi régióban nagyobb arányban vannak a 20-24 évesek.

${ }^{31}$ A „,képzési olló” kiegyenlítődése azt jelenti, hogy miközben csökken az iskolarendszerbe belépők száma, addig növekszik a felsőfokú végzettek aránya (Salat et al. 2010). 
Korábbi kutatások szerint (Csata 2004; Kiss 2014; Veres 2017a) az egyetemi továbbtanulás esélyét leginkább az apa iskolai végzettsége befolyásolja, a magasabb iskolai végzettségủek gyerekei tanulnak tovább a legnagyobb arányban. Jelen elemzés is arra enged következtetni, hogy az apa iskolai végzettségének ma is fontos szerepe van, mindkét évben szignifikáns összefüggést állapíthatunk meg a megkérdezett fiatal és az apa iskolai végzettsége között.

A társadalmi egyenlőtlenségek az iskolai végzettség és településtípus összefüggéseiben is megmutatkoznak: a lakhely településtípusa hatással van a továbbtanulás mértékére, mindkét esetben szignifikáns összefüggés van a településtípus és az iskolai végzettség között. A nagyobb városokban élő fiatalok inkább felsőfokú végzettségüek, a legfeljebb 8 osztállyal rendelkező, illetve szakiskolát végzettek inkább falusi környezetből származó fiatalok. 2001-ben a legfeljebb 8 osztály végzettek 35 százaléka lakik megyeszékhelyen, 19 százaléka más városban, közel 45 százaléka pedig községben/faluban. 2016-ban a legfeljebb 8 osztályt végzettek 23 százaléka lakik megyeszékhelyen, 22 százaléka más városban, 56 százaléka pedig községben/faluban. (Lásd. Melléklet. 10.7. táblázat) A felsőfokú végzettséggel rendelkezők arányait vizsgálva lényeges változást állapíthatunk meg, a falusi környezetből származó felsőfokú végzettek aránya 2001-ben mindössze 14 százalék, 2016-ban arányuk 38 százalékra emelkedett. (Lásd. Melléklet. 10.7. Táblázat.) Jellemző ugyan a növekedés falun, 5,2 százalékról felmegy 14,7-re, de megyeszékhelyen is megugrik ez az arány, 17-röl 32re (lásd. 6.1 és 6.2. táblázat.). Az, hogy falun közel megtriplázódott a felsőfokú végzettségüek aránya az egyenlőtlenségek mérséklődésére utalhat. Az iskolai végzettség szocio-demográfiai ismérvek szerinti eloszlását a 6.1-6.2. táblázatban foglaltuk össze. A kereszttábla eredményei alapján azt mondhatjuk, hogy a folyamatosan bővülő oktatási rendszer a magyar fiatalok körében magasabb képzettségi szintet von maga után, sok fiatalnak van magasabb iskolai végzettsége a szülei (apa) iskolai státusánál. A településszerkezeti eloszlást összegezve megfigyelhető egy elmozdulás, a kisebb településeken élő fiatalok is egyre nagyobb arányban szereznek felsőfokú diplomát, a Cramer`s V asszociációs mérőszám is arra utal, hogy a településszerkezeti különbségek mérséklődtek az évek során. A településszerkezet és az iskolai végzettség közötti összefüggés 2001-ben erősebb volt $(0,214)$, mint 2016-ban $(0,169)$, ennek ellenére még mindig nagy a különbség a falvak és nagyvárosok között. Hasonlóképpen a megkérdezett iskolai végzettsége és az apa iskolai végzettsége közötti összefüggés is mérséklődött (2001-0,255 és 2016-ban 0,164). Amennyiben a konkrét számokat nézzük is ez köszön vissza, hiszen 2001-ben az alapfokú végzettségü apák gyerekeinek 4,3 százaléka volt felsőfokú végzettségü, 2016-ban viszont 
16 százalékának. A felsőfokú végzettségü apáknál ez az arány 27-ről 23-ra csökkent. (lásd. 6.1 és 6.2. táblázatokat).

6.1. táblázat: Iskolai végzettség eloszlása különbözö szocio-demográfiai kategóriákban. Mozaik 2001

\begin{tabular}{|c|c|c|c|c|c|}
\hline & $\begin{array}{c}\text { legfeljebb } 8 \\
\text { osztály }\end{array}$ & $\begin{array}{l}\text { szakmunkás- } \\
\text { képző }\end{array}$ & érettségi & $\begin{array}{c}\text { felsőfokú } \\
\text { végzettség }\end{array}$ & $\begin{array}{c}\text { Cramer`s } \\
\mathrm{V}\end{array}$ \\
\hline Településtipus*** & & & & & 0,214 \\
\hline Megyeszékhely & 17,7 & 13,5 & 51,8 & 17,0 & \\
\hline Más város & 20,6 & 14,8 & 53,7 & 10,9 & \\
\hline Falu & 32,1 & 30,6 & 32,1 & 5,2 & \\
\hline $\mathrm{Nem}^{* * *}$ & & & & & 0,179 \\
\hline Férfi & 26,3 & 31,7 & 32,0 & 9,9 & \\
\hline Nő & 26,6 & 19,3 & 47,1 & 7,0 & \\
\hline $\begin{array}{l}\text { Apa iskolai vég- } \\
\text { zettsége } * * *\end{array}$ & & & & & 0,255 \\
\hline $\begin{array}{l}\text { Általános is- } \\
\text { kola/szakiskola }\end{array}$ & 27,8 & 34,0 & 33,9 & 4,3 & \\
\hline $\begin{array}{l}\text { Elméleti lí- } \\
\text { ceum/főiskola }\end{array}$ & 27,9 & 10,9 & 48,8 & 12,5 & \\
\hline $\begin{array}{l}\text { Egyetemi végzett- } \\
\text { ség }\end{array}$ & 19,8 & 4,0 & 49,2 & 27,1 & \\
\hline $\begin{array}{l}\text { Apa foglalko- } \\
\text { zása*** }\end{array}$ & & & & & 0,155 \\
\hline $\begin{array}{l}\text { Alkalmazottként } \\
\text { dolgozik }\end{array}$ & 27,9 & 21,2 & 43,4 & 7,6 & \\
\hline $\begin{array}{l}\text { Saját vállalkozás- } \\
\text { ban }\end{array}$ & 31,0 & 11,0 & 52,0 & 6,0 & \\
\hline $\begin{array}{l}\text { Gazdaságilag in- } \\
\text { aktív }\end{array}$ & 15,6 & 32,9 & 39,0 & 12,5 & \\
\hline $\begin{array}{l}\text { Gazdaságban dol- } \\
\text { gozik, alkalmi } \\
\text { munkából él }\end{array}$ & 49,6 & 23,6 & 22,0 & 4,9 & \\
\hline Egyéb & 38,2 & 30,9 & 29,1 & 1,8 & \\
\hline
\end{tabular}

Khi négyzetek:108.870; 60.543; 226.837; 121.795;

$* \mathrm{p}<0,05 ; * * \mathrm{p}<0,01 ; * * * \mathrm{p}<0.001$;

Nemek tekintetében szintén szignifikáns az összefüggés: számottevő változás a két adatfelvétel között. A fiatal nők valamivel nagyobb valószínüséggel szereznek felsőfokú végzettséget: a felsőfokú végzettséggel rendelkező nők aránya 2016-ban 3 százalékponttal nagyobb, mint a férfiaké. Azt, hogy az oktatási rendszer minden szintjén markáns különbségek figyelhetők meg a férfiak és a nők iskolázottsága között, és hogy a felsőoktatás expanziója nemcsak a diplomások, hanem a nők arányának növekedéséhez is hozzájárult, más kutatások is dokumentálták. 
6.2. táblázat: Iskolai végzettség eloszlása különbözö szocio-demográfiai kategóriákban. Magyar Ifjúság Kutatás 2016

\begin{tabular}{|c|c|c|c|c|c|}
\hline & $\begin{array}{l}\text { legfeljebb } \\
8 \text { osztály }\end{array}$ & $\begin{array}{l}\text { szakmun- } \\
\text { kásképző }\end{array}$ & érettségi & $\begin{array}{l}\text { felsőfokú } \\
\text { végzettség }\end{array}$ & $\begin{array}{c}\text { Cramer's } \\
\mathrm{V}\end{array}$ \\
\hline \multicolumn{2}{|l|}{ Településtipus*** } & & & & 0,169 \\
\hline Megyeszékhely & 29,0 & 2,3 & 36,6 & 32,2 & \\
\hline Más város & 34,3 & 6,1 & 41,0 & 18,6 & \\
\hline Falu & 37,0 & 13,0 & 35,3 & 14,7 & \\
\hline$N e m * * *$ & & & & & 0,134 \\
\hline Férfi & 32,5 & 12,2 & 36,3 & 19,0 & \\
\hline Nő & 36,1 & 4,7 & 37,6 & 21,6 & \\
\hline \multicolumn{2}{|l|}{ Apa iskolai végzettsége*** } & & & & 0,164 \\
\hline Általános- v szakiskola & 32,5 & 13,3 & 38,2 & 16,0 & \\
\hline Elméleti líceum/főiskola & 31,9 & 3,0 & 38,5 & 26,6 & \\
\hline Egyetemi végzettség & 44,5 & 0,9 & 31,4 & 23,2 & \\
\hline \multicolumn{2}{|l|}{ Apa foglalkozása $* * *$} & & & & 0,108 \\
\hline fizikai & 31,4 & 10,7 & 38,0 & 19,9 & \\
\hline szellemi & 33,8 & 3,0 & 37,2 & 26,0 & \\
\hline vezető & 45,2 & 1,7 & 32,2 & 20,9 & \\
\hline
\end{tabular}

Khi négyzetek:113.438; 35.676; 98.835; 40.709;

$* \mathrm{p}<0,05 ; * * \mathrm{p}<0,01 ; * * * \mathrm{p}<0.001$;

Geambașu (2008) az erdélyi magyar 21-44 éves korosztály iskolai végzettségét vizsgálva írja, hogy a nők túlreprezentáltak a legfeljebb általános iskolát, elméleti líceumot végzettek és érettségizettek csoportjában. Kisebb ugyan az eltérés az eddigi kategóriákhoz viszonyítva, de a felsőfokú diplomával rendelkezők körében is nagyobb arányban szerepelnek nők, mint férfiak. A férfiak csak a szakmunkásképzőt és szakiskolát végzettek kategóriájában haladják meg - szinte kétszeresen - a nők arányát (Geambaşu 2008). Magyarországon szintén megemelkedett a nők iskolázottsága, az oktatási szintek tömegessé válása következtében, olyannyira, hogy mind a közép-, mind a felsőfokú végzettek körében a nők kerültek többségbe (Nagy 2014b).

Egy további magyarázó változónk, az apa foglalkozása, ami szintén szignifikáns kapcsolatot mutat az iskolai végzettséggel. Magasabb státusú, azaz szellemi foglalkozású szülők gyerekei inkább rendelkeznek felsőfokú végzettséggel, de legerősebb öszszefüggés a megkérdezett iskolai végzettsége és a településszerkezet, valamint az apa iskolai végzettsége között van. 


\subsection{Anyagi helyzet}

A fiatalok anyagi helyzetét elsősorban szubjektív mutatók mentén vizsgáljuk. ${ }^{32}$ Az eredményeket a mellékletben található 10.1. ábra a 10.3. és 10.4. táblázatok, illetve a 6.3. táblázat foglalja össze. A 10.1. ábra alapján az látható, hogy a fiatalok relatív jóléte jelentősen megemelkedett: míg 2001-ben még 11 százalékuk nyilatkozott úgy, hogy hónapról hónapra anyagi gondjaik vannak, 2016-ra ez az arány 3 százalékra csökkent. Ezzel összhangban 2016-ban a fiatalok 22 százaléka említette, hogy gondok nélkül él, 2001-ben ez az arány csupán 6 százalék volt, ez számottevő jóléti- és életszínvonalbeli emelkedést jelent.

Ezt a növekedést az ország általános gazdasági fejlödése is mutatja: Romániában az elmúlt húsz évben jelentős volt a gazdasági fejlődés mértéke, a nettó átlagjövedelem $^{33}$ közel háromszorosára nőtt 2005 (235 EUR) és 2019 (615 EUR) között. A vásárlóerő-paritáson ${ }^{34}$ számolt egy före jutó bruttó hazai termék (GDP) alakulása is mutatja az életszínvonal javulását: Romániában 2005 és 2017 között 12,428 és 24,508 USD, bár ez jóval az uniós életszínvonal alatt marad, ahol ez az érték 29,640-ről 41,175-re emelkedett.

A két felmérés alapján megvizsgáltuk, hogy milyen hatással van a szubjektív jólétre a lakóhely, a nem, az apa iskolai végzettsége és foglalkozása, illetve a megkérdezett munkaerőpiaci státusza. A szubjektív jólét ${ }^{35}$ és településszerkezeti összefüggések az egyenlőtlenségek mérséklődésére utalnak: 2001-ben még szignifikáns kapcsolat mutatható ki a jólét és a településtípusok között. A városon élő fiatalok jobb anyagi körülmények között éltek, mint a falun élő fiatalok, 2016-ban viszont a szubjektív jólét és településtípus között már nem találtunk szignifikáns összefüggést (lásd.

${ }^{32} \mathrm{Az}$ életminőséget és anyagi helyzetet a fogyasztói javakkal való rendelkezésen keresztül szerettük volna megvizsgálni, viszont nem tudunk releváns összehasonlításokat tenni, ugyanis a 2016-os felmérésben a tartós fogyasztási cikkekre vonatkozó hagyományos kérdésblokk (automata mosógép, saját hőközpont, vezetékes víz, saját autó stb.) nem volt megkérdezve, a kutatás inkább a digitális korszakra jellemző eszközök birtoklására tér ki, csupán két közös kérdés van: a mobiltelefonnal illetve számítógéppel való rendelkezés.

${ }^{33} \mathrm{http}: / / \mathrm{www}$. insse.ro/cms/ro/content/c\%C3\%A2\%C8\%99tiguri-salariale-din-1991-serielunar $\% \mathrm{C} 4 \% 83$

${ }^{34} \mathrm{http}: / /$ www.ksh.hu/stadat_eves_7

${ }^{35}$ A szubjektív jólétet mindkét évben egy ötös skálán mérték: 5-gondok nélkül él, 4-beosztással jól kijönnek, 3-éppen hogy kijönnek a jövedelmükböl, 2-hónapról-hónapra anyagi gondjaik vannak, 1nélkülözések között élnek 
Melléklet 10.3. - 10.4. táblázat). Nemek tekintetében sem 2001-ben, sem 2016-ban nincs szignifikáns összefüggés.

6.3. táblázat: Szubjektív jólét szocio-demográfiai ismérvek szerinti eloszlása (átlagok) 2001-2016

\begin{tabular}{|c|c|c|c|c|}
\hline & 2001 & Eta négyzet & 2016 & Eta négyzet \\
\hline Településtípus & & $\begin{array}{c}.013 \\
(.000) \\
\end{array}$ & & $\begin{array}{c}.004 \\
(.020) \\
\end{array}$ \\
\hline Megyeszékhely & 3.50 & & 3.91 & \\
\hline Más város & 3.38 & & 4.04 & \\
\hline Falu & 3.25 & & 3.99 & \\
\hline $\mathrm{Nem}$ & & $\begin{array}{c}.000 \\
(.843) \\
\end{array}$ & & $\begin{array}{c}.000 \\
(.891) \\
\end{array}$ \\
\hline Férfi & 3.36 & & 3.98 & \\
\hline Nö & 3.35 & & 3.98 & \\
\hline Apa iskolai végzettsége & & $\begin{array}{c}.029 \\
(.000)\end{array}$ & & $\begin{array}{c}.034 \\
(.000) \\
\end{array}$ \\
\hline Általános iskola/szakiskola & 3.28 & & 3.88 & \\
\hline Elméleti líceum/főiskola & 3.56 & & 4.06 & \\
\hline Egyetemi végzettség & 3.66 & & 4.28 & \\
\hline Apa foglalkozása & & $\begin{array}{c}.024 \\
(.000) \\
\end{array}$ & & $\begin{array}{c}.035 \\
(.000) \\
\end{array}$ \\
\hline Alkalmazottként dolgozik & 3.44 & & 3.92 & \\
\hline Saját vállalkozásban & 3.79 & & 4.17 & \\
\hline Gazdaságilag inaktív & 3.33 & & 4.32 & \\
\hline Gazdaságban dolgozik, alkalmi munkából él & 3.14 & & & \\
\hline Mivel foglalkozik? & & $\begin{array}{c}.039 \\
(.000) \\
\end{array}$ & & $\begin{array}{c}.014 \\
(.000) \\
\end{array}$ \\
\hline Tanul & 3.55 & & 4,06 & \\
\hline Dolgozik & 3.34 & & 3,93 & \\
\hline Egyik sem & 3.02 & & 3,75 & \\
\hline
\end{tabular}

A 6.3. ANOVA táblázat, illetve a szórás mutatók ${ }^{36}$ (6.3. táblázat) egy árnyaltabb képet adnak az összefüggésekről. A szórásnégyzet a független változók (nem, településtípus, apa iskolai végzettsége, apa foglalkozása, az egyén foglalkozása) hatásának erősségét méri a függő változóra, a jövedelemre. A kapott átlagértékek alapján megállapíthatjuk, hogy az összefüggés továbbra is szignifikáns, a szubjektív jólét

${ }^{36}$ Az eta négyzet a minta hatásnagyságáról ad információt, a független változó hatásának erősségét méri a függő változóra. Az eta a külső és a teljes szórásnégyzetet hasonlítja össze, ennek magyarázata $\mathrm{az}$, hogy ha $\mathrm{X}$ független változó nagy hatással van az Y függő változóra, akkor ennek a csoportok különbözőségében kell megnyilvánulnia, amit viszont a külső szórásnégyzet fejez ki. A szórásnégyzet a csoportátlagok egymástól való szignifikáns eltérését mutatja. 
érzékelése nőtt a falvakban élő fiatalok esetében, ugyanakkor a városi fiatalok esetében is. Tehát inkább egy általános életszínvonalbeli javulásról van szó (ami mindkét, sőt mindhárom településtípusra jellemző), mintsem az egyenlőtlenségek csökkenéséröl a településtípusok között.

Az apa iskolai végzettsége és foglalkozása, valamint a fiatalok jóléti percepciója között mindkét évben pozitív szignifikáns kapcsolat van. Minél magasabb iskolai végzetséggel, illetve foglalkozási státussal rendelkezik az apa, annál jobb a fiatalok szubjektív jóléti körülménye. A fiatalok státusát vizsgálva azt láthatjuk, hogy a „tanulói” státus nagyobb biztonságot nyújt a fiataloknak, feltehetően azért, mert a szülők anyagi helyzete is javult, és még számíthatnak a támogatásukra. A 15-29 éves korosztály, ha már dolgozik is, még nincs egy biztos munkaerőpiaci státusa, éppen ezért ebben a periódusban anyagilag instabilnak mutatkoznak.

A fiatalok munkaerőpiaci helyzetképét vizsgálva (lásd. Melléklet 10.5. táblázat) a két bevont kutatásból azt láthatjuk, hogy 2001-ben a fiatalok egyharmada tanul, kicsivel több mint fele dolgozik (gazdaságilag aktív), 17,8 százalékuk inaktív, ebből 8,6 százalékuk munkanélküli (járadékos vagy járadék nélküli). A 2016-os felmérés eredményei alapján a fiatalok fele az, aki fötevékenységként a tanulást jelölte meg, ebből 18 százalékuk a tanulás mellett valamit dolgozik is. 43,8 százalékuk fötevékenységként dolgozik, de ugyanakkor 16,5 százalékuk tanul is valamilyen formában a munka mellett, és mindössze 6,2 százalékuk inaktív. A munkanélküliek aránya ebben az évben mindössze 2 százalék (lásd. Melléklet 10.6. táblázat).

A 15-29 év közötti fiatalok iskolai végzettségére és munkaerőpiaci helyzetére vonatkozó adatok szerint az erdélyi magyar fiatalok körében is tetten érhető a korszakváltás jelensége, az oktatás felértékelődése, az ifjúsági korszak meghosszabbodása. Míg 2001-ben a megkérdezett fiatalok egyharmada, 29,5 százaléka tanult, ez az arány 2016-ban jelentősen megemelkedett, a megkérdezett fiatalok 50 százaléka tanul vagy részt vesz valamilyen képzésben. Megjelenik a tanulás melletti munka, illetve a munka melletti tanulás, ami egy újkeletü tevékenységi forma. 


\subsection{Foglalkozási rétegszerkezet 2001-2016}

A tanulmány következő részében a fiatalok foglalkozási struktúráját is megvizsgáltuk. A munkaerőpiacon aktívan dolgozó fiatalok esetében készítettünk egy foglalkozási rétegződési sémát, figyelembe véve a bejelentett utolsó foglalkozást.

Bár a legújabb rétegződéskutatások szakirodalma (Hradil 1995; Pakulski-Waters 1996; Beck 2004; Csite-Kovács-Kristóf 2006) egyre fontosabbnak és sürgősebbnek tartja a hagyományos paradigmák újragondolását, amelyek a társadalmi egyenlőtlenségeket az egyének munkaerő-pozícióját kifejező, foglalkozások alapján létrehozott munkajelleg csoportok alapján írják le, kiindulópontként mégis fontosnak tartjuk megnézni, hogy hogyan néz ki a fiatalok foglalkozási szerkezete 2001 és 2016 között.

A foglalkozási csoportok aggregálásában az összehasonlítást megnehezítette, hogy a két kutatás különböző módon kérdezett rá a munkaerőpiaci helyzetre. A Magyar Ifjúság Kutatás 2016-os kérdőíves felmérés során a foglalkozást nem rögzítették, hanem már eleve egy olyan sémát alkalmaztak, ahol a foglalkozások nagyobb kategóriákba voltak besorolva (1) Tanul (2) Dolgozik: fizikai ${ }^{37}$, szellemi $^{38}$, vezetö ${ }^{39}$, (3) egyik sem ${ }^{40}$. Mivel a 2016-os felmérésben nem volt adat a részletes foglalkozási kategóriákra, ezért mindkét esetben a kérdőíves rögzítéskor alkalmazott nagyobb foglalkozási kategóriákat (foglalkozási csoportosításokat) hasonlítottuk össze.

Egy másik nehézség a fiatalok foglalkozási rétegszerkezetének vizsgálatában, hogy ifjúsági korszakválás következtében egyre később kerülnek be a munkaerőpiacra (Gábor 2004), tehát a megkérdezett fiatalok csak egy kisebb részét tudjuk bevonni az elemzésbe. Másrészt az elmúlt évtizedekben jelentősen megváltoztak a munkaviszonyok. Olyan rugalmas foglalkoztatási formák válnak elterjedté a munkaerőpiacon, mint a részmunkaidős állások, az önfoglalkoztatottság, a meghatározott időtartamra szóló szerződések, az alvállalkozói együttmüködések stb. (Csata et al. 2009). Az elemzés szempontjából ez egy lényeges módszertani problémát vet fel, ugyanis

\footnotetext{
${ }^{37}$ mezőgazdasági fizikai munkás, segédmunkás (nem mezőgazdasági), betanított munkás (nem mezőgazdasági), szakmunkás (nem mezőgazdasági), közvetlen termelésirányító (pl. müvezető)

38 egyéb (diplomához nem kötött) szellemi, beosztott diplomás

39 alsó vezető, középszintü vezető, felső vezető

${ }^{40}$ munkanélküli segélyt kap, munkanélküli-ellátás nélkül, háztartásbeli, eltartott, rokkantnyugdíjas, szociális segélyezett, gyermeknevelési szabadságon van.
} 
megtörténhet, hogy már az adatfelvétel ideje és az elemzés közötti periódusban a megkérdezett fiatal munkát vált, más tevékenységi formát végez. Tehát a fiatalok körében a foglalkozás egyre nehezebben mérhető.

Az oktatásból a munka világába való átmenet alapvető jellegzetessége a növekvő bizonytalanság, jellemzővé vált a munkahelyi életutak individualizálódása, és az egyre markánsabban megjelenő rugalmasság, ami fokozottabb kockázatot von maga után (Beck 2004). A folyamatosan újjászerveződő és kockázati tényezőket rejtegető munkaerőpiac körülményeire a fiatalok gyakran az oktatási rendszerben való bennmaradással válaszolnak (Galasi-Timár-Varga 2001). Ezek a folyamatok a rendszerváltást és az Európai Unióhoz való csatlakozást követően Romániában is látványosan felgyorsultak (Csata-Dániel-Pop 2006).

Figyelembe véve a kelet-közép-európai sajátosságokat, a fiatalok foglalkozási rétegekbe sorolásakor elsősorban Veres Valér klasszifikációját használtuk mintaként (Veres 2014), ugyanakkor szem előtt tartottuk a foglalkozási osztályszerkezet egyik legfontosabb nemzetközi modelljét az EGP sémát is (Erikson-Goldthorpe-Portocarero 1988), ami többféle tényezőre is támaszkodik. Egyik legfontosabb választóvonal, hogy különbséget tesz a foglalkoztatók, az önfoglalkoztatók, illetve az alkalmazottak csoportjai között. A csoportok aggregáltsági szintje az EGP séma 11-es változatához hasonlít a legjobban, bár mi csak 9 kategóriát határoztunk meg. 


\begin{tabular}{|c|c|c|}
\hline Foglalkozási rétegek (23) & Foglalkozási rétegek (7) & Foglalkozási rétegek (8) \\
\hline \multicolumn{3}{|l|}{ Tanul } \\
\hline \multirow{2}{*}{ Alkalmazottként dolgozik } & \multirow{2}{*}{ Alkalmazottként dolgozik } & Nem fizikai dolgozó \\
\hline & & Szakmunkás \\
\hline saját vállalkozásban dolgozik & \multirow{3}{*}{$\begin{array}{l}\text { Vállalkozó (önfoglalkoz- } \\
\text { tató) }\end{array}$} & \multirow{3}{*}{ Vállalkozó } \\
\hline vállalkozásban segítő családtag & & \\
\hline jövedelmeiből él (tőzsdézik, lakáskiadás) & & \\
\hline szellemi szabadfoglalkozású & Szellemi (értelmiségi) & Szellemi (értelmiségi) \\
\hline Családi gazdaságban dolgozik & Gazdálkodó & Gazdálkodó \\
\hline Alkalmi munkákból, megbízásokból él & \multirow{2}{*}{$\begin{array}{l}\text { Szakképzetlen, alkalmi } \\
\text { munkás }\end{array}$} & \multirow{2}{*}{$\begin{array}{l}\text { Szakképzetlen, alkalmi } \\
\text { munkás }\end{array}$} \\
\hline Fekete munka (maszek munka) & & \\
\hline Sorkatona, van állása & \multirow{11}{*}{ Inaktív } & \multirow{11}{*}{ Inaktív } \\
\hline Sorkatona, nincs állása & & \\
\hline $\begin{array}{l}\text { Gyermekgondozási Segély, Gyermekgondo- } \\
\text { zási Díj, Gyermekgondozási Támogatás, } \\
\text { szülési szabadság - nincs állása }\end{array}$ & & \\
\hline $\begin{array}{l}\text { - Gyermekgondozási Segély, Gyermekgon- } \\
\text { dozási Díj, Gyermekgondozási Támogatás, } \\
\text { szülési szabadság - van állása }\end{array}$ & & \\
\hline Háztartásbeli & & \\
\hline $\begin{array}{l}\text { Eltartott (otthon van, pl. munkanélküli jöve- } \\
\text { delempótló nélkül) }\end{array}$ & & \\
\hline Öregségi nyugdíjas & & \\
\hline $\begin{array}{l}\text { Leszázalékolt, rokkantnyugdíjas, betegnyug- } \\
\text { díjas }\end{array}$ & & \\
\hline $\begin{array}{l}\text { Olyan nyugdíjaskorú, aki nem részesül } \\
\text { nyugdíjban (nem dolgozik) }\end{array}$ & & \\
\hline Szociális segélyezett & & \\
\hline Egyéb inaktív & & \\
\hline Munkanélküli járadékos, segélyezett & \multirow{3}{*}{ Munkanélküli } & \multirow{3}{*}{ Munkanélküli } \\
\hline Jövedelempótlós, közhasznú foglalkoztatott & & \\
\hline Munkanélküli járadék nélkül & & \\
\hline
\end{tabular}

A klasszifikáció menetét a fenti - 6.4. - táblázat mutatja be: az első oszlopban 23 foglalkozási- és munkajelleg csoport található, ahogy ez a kérdőívben is szerepel. A rákövetkező oszlopban hét foglalkozási réteget látunk, amelyeket automatikusan vontussnk össze, majd a harmadik oszlopban, az iskolai végzettséget figyelembe véve bontottuk fel az ,alkalmazottakat” szakmunkásokra és nem fizikai dolgozókra. 


\begin{tabular}{|l|c|c|}
\hline \multicolumn{1}{|c|}{ Foglalkozási státusok } & MOZAIK 2011 N=1460 & Ifjúság 2016 N=1891 \\
\hline vállalkozó, vezető & 2.5 & 4.1 \\
\hline diplomás, szellemi (értelmiségi) & 8.6 & 7.4 \\
\hline nem fizikai dolgozó & 17.6 & 14.6 \\
\hline szakmunkás & 15.5 & 14.0 \\
\hline gazdálkodó & 4.2 & 1.2 \\
\hline szakképzetlen, alkalmi munkás & 9.7 & 5.0 \\
\hline munkanélküli & 9.6 & 6.9 \\
\hline tanul & $32.3 \mathrm{~N}=549$ & $46.7 \mathrm{~N}=884$ \\
\hline
\end{tabular}

A foglalkozási státusok kialakítását azért tartottuk fontosnak, mert kíváncsiak voltunk, hogy milyen változások vannak a fiatalok foglalkozási rétegszerkezetében. Az össznépesség foglalkozásszerkezetében az a trend figyelhető meg, hogy a foglalkoztatás elmozdul a szolgáltató szektor, a szellemi és a nem fizikai munkavégzés irányába. Ezáltal a középosztályra jellemző foglalkozásúak aránya megnövekedik, de még mindig alacsonyabb a nyugat-európai országok átlagánál. A 2002-es népszámlálás óta országos szinten a szakértők és az értelmiségi foglalkozásúak aránya mintegy 7 százalékkal, a szolgáltatásbeli dolgozók aránya 4,5 százalékponttal (9-röl 13,5 százalékra) emelkedett. Az erdélyi magyarok társadalomszerkezete két lényeges ponton tér el az össznépességtől: az iparban dolgozó szakmunkások aránya magasabb, a mezőgazdaságban dolgozók aránya alacsonyabb (Veres 2013).

A fiatalok foglalkozási rétegszerkezetében (lásd. 6.5. táblázat) az össznépességhez hasonló változásokat állapíthatunk meg. Mindenekelőtt csökkent a munkanélküliek aránya, ami feltehetőleg csak kisebb részben gazdasági fellendülés eredménye, inkább annak tudható be, hogy a fiatalok egyre inkább választják a tanulást parkolópályának, a munkanélküliség helyett. Ugyanakkor arra a változásra is rámutattunk, hogy kevesebb a fiatalok között a szakképzetlen munkás és gazdálkodó, nagyobb arányban vannak vállalkozók, illetve vezetők. A nem fizikai dolgozók aránya, bár kismértékben, de csökkent. Továbbá nem számottevően, de a diplomás, értelmiségi foglalkozási státus is csökkent egy százalékpontot, amely valószínűsíthetően a vállalkozói szférába tolódott át. 
6.6. táblázat: Foglalkozási státusok szocio-demográfiai ismérvek szerinti eloszlása.

Mozaik 2001

\begin{tabular}{|c|c|c|c|c|c|c|c|}
\hline & $\begin{array}{c}\text { vállalkozó, } \\
\text { vezető }\end{array}$ & \begin{tabular}{|c|} 
diplomás, \\
szellemi (ér- \\
telmiségi) \\
\end{tabular} & $\begin{array}{c}\text { nem fizikai } \\
\text { dolgozó }\end{array}$ & $\begin{array}{c}\text { szak- } \\
\text { munkás }\end{array}$ & $\begin{array}{c}\text { gazdál- } \\
\text { kodó }\end{array}$ & $\begin{array}{l}\text { szakképzetlen, } \\
\text { alkalmi munkás }\end{array}$ & $\begin{array}{l}\text { munka- } \\
\text { nélküli }\end{array}$ \\
\hline \multicolumn{8}{|l|}{ Településtípus $* * *$} \\
\hline Megyeszékhely & 4.2 & 24.0 & 31.7 & 16.4 & .0 & 13.4 & 10.3 \\
\hline Más város & 5.3 & 17.3 & 38.7 & 13.3 & .0 & 4.7 & 20.7 \\
\hline Falu & 3.2 & 10.7 & 24.2 & 23.4 & 11.1 & 13.5 & 13.9 \\
\hline \multicolumn{8}{|l|}{$\mathrm{Nem}^{* *}$} \\
\hline Férfi & 4.6 & 12.7 & 16.9 & 26.3 & 8.0 & 17.9 & 13.7 \\
\hline Nő & 2.4 & 12.7 & 36.4 & 19.1 & 4.3 & 10.5 & 14.6 \\
\hline \multicolumn{8}{|c|}{ Apa iskolai végzettsége ${ }^{* * *}$} \\
\hline $\begin{array}{l}\text { Általános is- } \\
\text { kola/szakiskola }\end{array}$ & 2.9 & 7.1 & 23.2 & 28.2 & 7.5 & 16.4 & 14.6 \\
\hline $\begin{array}{l}\text { Elméleti líceum/fóis- } \\
\text { kola }\end{array}$ & 5.1 & 20.5 & 36.9 & 10.8 & 1.7 & 13.1 & 11.9 \\
\hline Egyetemi végzettség & 5.4 & 51.4 & 27.0 & 4.1 & .0 & .0 & 12.2 \\
\hline \multicolumn{8}{|l|}{ Apa foglalkozása *** } \\
\hline $\begin{array}{l}\text { Alkalmazottként } \\
\text { dolgozik }\end{array}$ & 3.1 & 14.3 & 30.8 & 23.9 & 2.1 & 11.3 & 14.6 \\
\hline Saját vállalkozásban & 18.4 & 15.8 & 36.8 & 15.8 & 2.6 & 5.3 & 5.3 \\
\hline Gazdaságilag inaktív & 3.9 & 14.7 & 26.5 & 26.3 & 4.6 & 10.6 & 13.4 \\
\hline $\begin{array}{l}\text { Gazdasági dolgozó, } \\
\text { alkalmi munkás }\end{array}$ & .0 & 5.6 & 11.2 & 13.5 & 31.5 & 32.6 & 5.6 \\
\hline
\end{tabular}

Khi négyzetek:87.835; 69.453; 188.559; 195,679; Cramer`s V. 0,257; 0,246; 0,300; 0,263;

$* \mathrm{p}<0,05 ; * * \mathrm{p}<0,01 ; * * * \mathrm{p}<0.000$;

Azt láthatjuk tehát, hogy foglalkozás szerinti rétegződés alapján csökkent a fizikai munkások - különösen a mezőgazdaságban dolgozók - aránya. Az iskolai végzettség alapján nőtt a magasan képzett szakemberek aránya. Ezzel egyidőben megjelent egy szélesebb vállalkozói réteg.

Ezt követően kereszttábla elemzéssel megvizsgáltuk a fiatalok foglalkozási rétegszerkezete és a településtípus, nem, apa iskolai végzettsége, foglalkozása szerinti összefüggéseket. Az aktív fiatalok foglalkozási szerkezetét vizsgálva településtípus szerint a vállalkozó, diplomás/szellemi munkások, valamit a nem fizikai dolgozók többen vannak a megyeközpontokba és más városokba. Rurális környezetben pedig a szakmunkás, gazdálkodó, illetve szakképzetlen fiatalok vannak többségben. A munkanélküliek aránya, bár az évek során csökkent, szintén nagyobb arányban jellemző a falusi fiatalokra. 
6.7. táblázat: Foglalkozási státusok szocio-demográfiai ismérvek szerinti eloszlása.

Magyar Ifjúság Kutatás 2016

\begin{tabular}{|l|c|c|c|c|c|c|c|}
\hline & $\begin{array}{c}\text { vállal- } \\
\text { kozó, } \\
\text { vezető }\end{array}$ & $\begin{array}{c}\text { diplomás, } \\
\text { szellemi } \\
\text { (értelmi- } \\
\text { ségi) }\end{array}$ & $\begin{array}{c}\text { nem fizi- } \\
\text { kai dol- } \\
\text { gozó }\end{array}$ & $\begin{array}{c}\text { szak- } \\
\text { mun- } \\
\text { kás }\end{array}$ & $\begin{array}{c}\text { gaz- } \\
\text { dál- } \\
\text { kodó }\end{array}$ & $\begin{array}{c}\text { szakkép- } \\
\text { zaten, al- } \\
\text { kalmi } \\
\text { munkás }\end{array}$ & $\begin{array}{c}\text { mun- } \\
\text { kanél- } \\
\text { küli }\end{array}$ \\
\hline Településtípus*** & & & & & & & \\
\hline Megyeszékhely & 7.8 & 23.0 & 37.1 & 17.6 & .0 & 6.2 & 8.2 \\
\hline Más város & 11.2 & 14.2 & 35.0 & 20.8 & 1.5 & 7.1 & 10.2 \\
\hline Falu & 6.5 & 9.6 & 20.4 & 32.2 & 3.6 & 11.6 & 16.1 \\
\hline Nem $* *$ & & & & & & & \\
\hline Férfi & 7.7 & 10.6 & 25.4 & 28.6 & 2.9 & 10.3 & 14.5 \\
\hline Nö & 7.7 & 18.6 & 30.5 & 22.8 & 1.5 & 8.0 & 10.9 \\
\hline Apa iskolai végzettsége*** & & & & & & & \\
\hline Általános iskola/szakiskola & 5.2 & 9.9 & 23.2 & 31.0 & 3.8 & 11.1 & 15.9 \\
\hline Elméleti líceum/föiskola & 11.4 & 19.0 & 35.9 & 19.7 & .3 & 4.5 & 9.3 \\
\hline Egyetemi végzettség & 9.9 & 25.4 & 43.7 & 7.0 & .0 & 11.3 & 2.8 \\
\hline Apa foglalkozása*** & & & & & & & \\
\hline fizikai & 5.9 & 12.6 & 26.7 & 30.4 & 2.7 & 8.3 & 13.4 \\
\hline szellemi & 9.1 & 25.5 & 42.7 & 8.2 & .0 & 6.4 & 8.2 \\
\hline vezető & 22.9 & 12.9 & 31.4 & 10.0 & 1.4 & 15.7 & 5.7 \\
\hline
\end{tabular}

Khi négyzetek:93.663; 22.681; 99.908; 83.052;

$* \mathrm{p}<0,05 ; * * \mathrm{p}<0,01 ; * * * \mathrm{p}<0.000$;

A foglalkozások nem egyformán jellemzők a férfiakra és a nőkre, ami a felsőoktatásban, de már a középfokú oktatásba való belépéskor is megmutatkozik. Az oktatásba belépő, növekvő volumenü női populáció inkább az elméleti képzésben vesz részt, ami az erőteljes iparosodás korszakában kevésbé nyújtott piacképes tudást (Geambașu 2008). A nők és férfiak munkaerőpiaci jelenlétében, foglalkozási szerkezetében is megállapíthatók eltérések. A férfiak kicsivel magasabb arányban vállalkozók/vezetők, bár ez 2016-ban egyenlő arányt mutat, a szellemi munkások körében éppen fordított jelleget ölt ez az arány. 2001-ben férfi-női diplomások egyenlő arányban vannak, 2016-ban a nők közel kétszer annyian végzenek szellemi munkát, mint a férfiak. Legnagyobb eltérés nemek szerint a nem fizikai dolgozók (akik inkább nők) és a szakmunkás csoportokban (akik inkább férfiak) tapasztalható. Úgy is fogalmazhatunk, hogy a szellemi foglalkozású rétegekben a nők, a hagyományos fizikai foglalkozású rétegekben a férfiak felülreprezentáltak. 
A másik két magyarázó változónk, az apa iskolai végzettsége és foglalkozása, illetve a megkérdezett fiatalok foglalkozási szerkezete, szintén szignifikáns összefüggésekre utalnak, ami a vertikális differenciálódást vetíti elö. Minél magasabb az apa iskolai végzettsége, annál valószínübb, hogy a megkérdezett fiatal vállalkozó vezető vagy értelmiségi foglalkozással rendelkezik, illetve az általános/szakiskolai végzettségű szülők gyerekei inkább szakmunkások. A vertikális tagoltság abban is megmutatkozik, hogy a legtöbb munkanélküli fiatalnak az apja iskolai végzettsége általános iskola vagy szakiskola, foglalkozása pedig fizikai munkás.

\subsection{Kulturális-szabadidős fogyasztói mintázatok}

A 20. század második felében Nyugat-Európában kialakult egy posztmodern értékeken alapuló fogyasztói társadalom, melynek jelei a posztszocialista országokban is megérkeztek, a kilencvenes évek elejére. A szükös életmódot felváltotta a fogyasztás kultúrája, egyre fontosabbá vált az egyéni szabadság, ami a fiatalok szabadidős forgatókönyvét is jelentősen befolyásolta (Gábor 2005) A rendszerváltás során végbement változások a kultúra szerkezeti átalakulását is maguk után vonták- A tömegkultúra és globalizáció elterjedésével, bár egyre színesebb lett a kínálat, mégis csökken a kulturális termékek iránti kereslet.

Jelen fejezetben a fiatalok szabadidő-használatát, kulturális fogyasztását és ennek időbeni dinamikáját mutatjuk be. Románia kulturális fogyasztás tekintetében igencsak hátul helyezkedik el az Európai Unióban. Mind a 2007-es mind pedig a 2013-as adatok szerint az utolsó öt ország között van. (Barna 2011). Jelentős csökkenés van a 2007-es felméréshez viszonyítva is, különösen a színházba, moziba járás és a könyvolvasás, tekintetében (lásd. Melléklet 10.10. táblázat). Bár az EU országaiban szinte mindenik kulturális tevékenység hanyatlott, a legnagyobb csökkenés Magyarországon, Romániában és Görögországban volt ${ }^{41}$. A kulturális tevékenységekben való részvétel ilyen alacsony szintje bizonyos mértékben összefügg az ország gazdasági

\footnotetext{
${ }^{41}$ Special Eurobarometer 399. Cultural Access and Participation. Report. 2013
} 
állapotával, ugyanis amikor a kultúrához való hozzáférés fő akadályait mérték a válaszadók leggyakoribb okoknak az ,időhiányt” (42\%), az ,érdektelenséget” (27\%) jelölték meg, illetve azt, hogy „túl drága” (29\%).

A Kultúrafogyasztási barométer ${ }^{42}$ címü felmérésekből szintén az derül ki, hogy Románia lakossága kulturális fogyasztás tekintetében igencsak alacsony aktivitást mutat: a megkérdezettek mintegy hatvan százaléka nem jár moziba, hasonlóképpen a színházba járás is meglehetően alacsony. 2014-ben a lakosság 63,2 százaléka soha nem volt színházban az elmúlt egy évben, ez 2018-ban már a lakosság 67 százalékára jellemző. A távolmaradást egyfelől az intézmény hiányával (vidék), másfelől a szabadidő hiányával (város), illetve a jegyárak megemelkedésével indokolták a megkérdezettek. Az olvasás is egyre nagyobb teret veszít Romániában, a megkérdezettek 3538 százaléka egyáltalán nem olvasott könyvet egész évben, ezzel szemben újságot egy kicsivel gyakrabban böngésznek az emberek.

Az erdélyi magyar fiatalok szabadidős fogyasztásának időbeni alakulását a MOZAIK 2001, a GeneZYs 2015 és a Magyar Ifjúság Kutatás 2016 felmérések alapján tekintjük át. Az összehasonlításnál nehézséget okoz, hogy a vizsgált színterek átalakultak, illetve újak jelentek meg a szabadidős palettán. További nehézséget okoz, hogy a szabadidős tevékenységek gyakoriságának a méréséhez különböző típusú skálákat alkalmaztak ${ }^{43}$. A MOZAIK 2001-es felmérés $11^{44}$, a Magyar Ifjúság Kutatás 2016 pedig 15 szabadidős tevékenységet ${ }^{45}$ mért. A 2015 -ös, GeneZYs ${ }^{46}$ felmérés ennél jóval gazdagabb változószettel vizsgálta a fiatalok szabadidős/kulturális fogyasztását 27 tevékenységre vonatkozóan.

Erdélyben a román és a magyar ifjúságszociológiai vizsgálatokat nagyfokú párhuzamosság jellemzi (Kiss-Barna 2011), a Magyarországhoz kötődő vizsgálatok során csupán a MOZAIK 2001-es felmérés zajlott egy kisebb román almintán is. Egy

\footnotetext{
42 Barometrul de Consum Cultural 2014, 2018.

${ }^{43}$ A kérdésfeltevés módja is eltérő volt: 2001-ben: Mikor volt Ön utoljára ...? 2016-ban pedig már a gyakoriságra fektették a hangsúlyt: Milyen gyakran jár Ön a következő helyekre?...

${ }^{44}$ Mikor volt Ön utoljára? 1 (1 hónapon belül), 2 (1-2 hónapja), 3 (4-6 hónapja), 4 (ennél régebben) 9 (soha)

${ }^{45}$ Milyen gyakran jár Ön az alábbi helyekre? 1 (hetente többször), 2 (hetente egyszer), 3 (havonta többször), 4 (2-3 havonta), 5 (évente többször), 9 (szinte soha).

${ }^{46}$ Milyen gyakran szoktad az alábbi tevékenységeket folytatni? 1-azt jelenti, hogy Soha, a 10es pedig azt jelenti, hogy nagyon gyakran.
} 
másik, 2008-ban végzett felmérés ${ }^{47}$ adhat még lehetőséget arra, hogy etnikai vonatkozásban is megnézzük miben különbözik az erdélyi magyar fiatalok kulturális fogyasztása a román fiataloktól. A fiatalok leggyakrabban látogatott színtere 2001-ben a diszkó $(32 \%)$ és a házi buli (28\%) volt, de könyvesboltba (36\%) is gyakran jártak, 2015-ben és 2016-ban a leggyakrabban látogatott helyszínek a kávéházak-teázók-sörözők-kocsmák-éttermek és bevásárlóközpontok lettek.

6.8. táblázat: Kulturális tevékenységek gyakorisága, MOZAIK 2001. Mikor volt utoljára az alábbi helyeken?

\begin{tabular}{|l|c|c|c|c|c|}
\hline & 1 hónapon belül & $1-2$ hónapja & 4-6 hónapja & ennél régebben & soha \\
\hline színházban (nézőként) & 10.6 & 5.9 & 17.2 & 51.4 & 14.9 \\
\hline moziban & 17.9 & 13.7 & 15.2 & 45.3 & 7.9 \\
\hline könyvtárban & 23.8 & 10.2 & 10.5 & 45.8 & 9.7 \\
\hline könnyüzenei koncerten & 9.5 & 11.9 & 20.2 & 38.1 & 20.3 \\
\hline diszkóban & 32 & 11.9 & 11.2 & 36.9 & 8 \\
\hline hangversenyen & 2.9 & 2.6 & 6.2 & 33.4 & 54.9 \\
\hline könyvesboltban & 36.1 & 17.6 & 13.1 & 25.3 & 7.9 \\
\hline müvelödési házban & 16.4 & 14.9 & 15.2 & 39.3 & 14.2 \\
\hline bálban, mulatságon & 26.7 & 20.2 & 18.2 & 30.1 & 4.8 \\
\hline házibuliban, partin & 27.6 & 18.7 & 17.6 & 29.1 & 6.9 \\
\hline kiállításon, múzeumban & 8.6 & 9.2 & 15.3 & 48.1 & 18.8 \\
\hline
\end{tabular}

A magaskultúra színterei kevésbé népszerüek: a fiatalok nagyrésze szinte soha nem látogatja ezeket a helyszíneket. A két legkevésbé látogatott kulturális intézmény az opera és a komolyzenei hangverseny. 2016-ban a fiatalok 85 százaléka válaszolta azt, hogy szinte soha nem látogat el operába. A hangversenyek látogatottságát mindkét évben mérték, 2001-ben a fiatalok több mint fele, 56 százaléka válaszolta azt, hogy nem volt komolyzenei koncerten, 2016-ban pedig a fiatalok 79 százalékára jellemző. 2015-ben szintén nagyon alacsony gyakoriságot mutat a hangverseny és opera látogatottsága. A magaskultúrát megjelenítő további színterek, mint a színház, kiállítások és múzeumok látogatottsága a korábbi évekhez viszonyítva szintén csökkenő tendenciát mutatnak. 2016-ban a fiatalok fele szinte soha nem volt színházban, múzeumban, illetve kiállításon, míg 2001-ben ez az arány csupán 15-19 százalék volt.

${ }^{47}$ Az Országos Ifjúsági Hatóság (ANT) kezdeményezte és a Nemzeti Kisebbségkutató Intézet (ISPMN) hajtotta végre. 2008 június-júliusában végzett teljes romániai fiatalságra reprezentatív felmérés. 2008 szeptemberében a romániai vizsgálathoz hasonló tematikájú felmérést egy magyar almintán is elvégezték. 
6.3. ábra: Kulturális tevékenységek gyakorisága, 2015. Milyen gyakran szoktad az alábbi tevékenységeket folytatni? (saját szerkesztés)

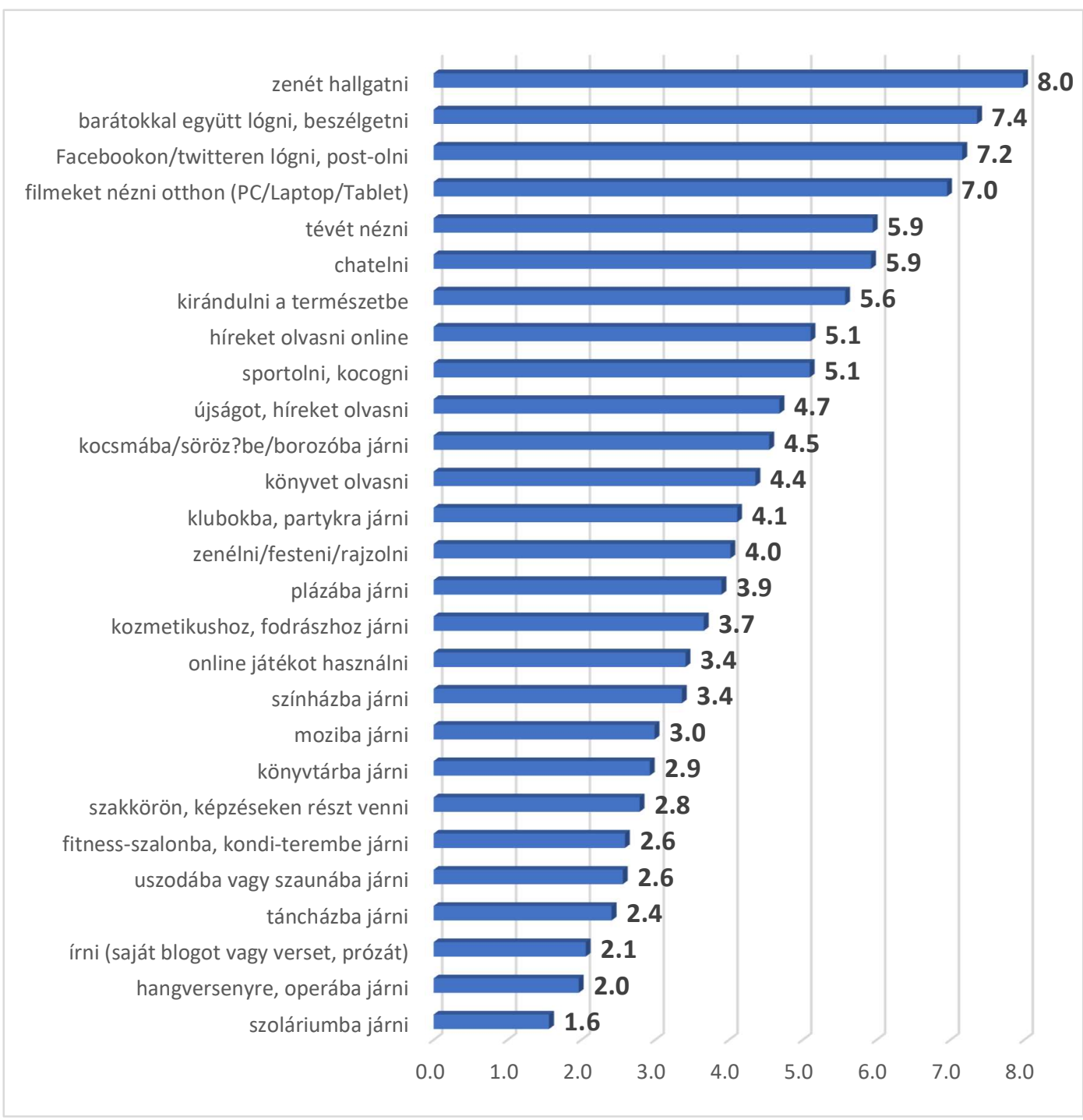

A táncház, illetve az art mozik hasonlóképpen nagyon kevés teret kapnak a fiatalok életében, a fiatalok több mint 70 százalékára nem jellemző az említett kulturális tevékenységek gyakorlása. A leggyakrabban látogatott kulturális terek a könyvesboltok és a könyvtárak, ahol a fiatalok fele megfordul valamilyen gyakorisággal. Ennél is gyakrabban a fiatalok kávézóba/teázóba/sörözőbe/kocsmába járnak. Összességében tehát azt mondhatjuk, hogy operába, hangversenyre és színházba jut el a legkevesebb fiatal, a legtöbben pedig kocsmába, sörözőbe, borozóba, kávézóba járnak. 
6.9. táblázat: Kulturális tevékenységek gyakorisága, Ifjúság 2016. Milyen gyakran jár az alábbi helyekre?

\begin{tabular}{|l|c|c|c|c|c|c|}
\hline & $\begin{array}{c}\text { hetente } \\
\text { többször }\end{array}$ & $\begin{array}{c}\text { hetente } \\
\text { egyszer }\end{array}$ & $\begin{array}{c}\text { havonta } \\
\text { többször }\end{array}$ & $\begin{array}{c}2-3 \text { ha- } \\
\text { vonta }\end{array}$ & $\begin{array}{c}\text { évente } \\
\text { többször }\end{array}$ & $\begin{array}{c}\text { szinte } \\
\text { soha }\end{array}$ \\
\hline színházban (nézőként) & 0.4 & 0.7 & 4.7 & 13.7 & 30.3 & 50.1 \\
\hline $\begin{array}{l}\text { art moziba, / müvész-fil- } \\
\text { meket nézni }\end{array}$ & 0.4 & 0.4 & 2.5 & 8.4 & 17.5 & 70.8 \\
\hline $\begin{array}{l}\text { multiplexbe vagy más } \\
\text { moziba }\end{array}$ & 0.4 & 0.5 & 5.8 & 13.3 & 26.5 & 53.4 \\
\hline könyvtárba & 2.7 & 3.1 & 10.7 & 12.9 & 22.9 & 47.8 \\
\hline $\begin{array}{l}\text { komolyzenei hangver- } \\
\text { senyre }\end{array}$ & 0.3 & 0.2 & 2 & 4.8 & 13.4 & 79.2 \\
\hline könnyüzenei koncertre & 0.1 & 0.3 & 4.7 & 12.7 & 43.8 & 38.5 \\
\hline könyvesboltba & 0.7 & 1.7 & 9.5 & 17.4 & 29.2 & 41.4 \\
\hline kiállításra, múzeumba & 0.2 & 0 & 5.5 & 11 & 36.3 & 47 \\
\hline operába & 0.2 & 0.5 & 1.5 & 3.6 & 8.6 & 85.6 \\
\hline kávéházba, teázóba & 16.2 & 15.9 & 28.9 & 16.9 & 10.9 & 11.2 \\
\hline $\begin{array}{l}\text { sörözőbe, borozóba, kocs- } \\
\text { mába presszóba }\end{array}$ & 16.5 & 17 & 23.6 & 13.5 & 10.3 & 19.1 \\
\hline étterembe & 5.7 & 7.3 & 24.6 & 27.2 & 23 & 12.1 \\
\hline $\begin{array}{l}\text { konditerembe, fitnesz } \\
\text { klubba }\end{array}$ & 7.3 & 3.5 & 5.8 & 7.4 & 13.9 & 62.1 \\
\hline plázába (mallba) & 4.6 & 5.2 & 25 & 22.2 & 21 & 22 \\
\hline \begin{tabular}{l} 
táncházba \\
\hline
\end{tabular} & 1.6 & 2.8 & 3.9 & 7.4 & 14 & 70.3 \\
\hline
\end{tabular}

Ma már a szabadidős szokások feltérképezéséhez elkerülhetetlen a fesztiválok vizsgálata $^{48}$, ami az elmúlt húsz évben a szabadidő eltöltési módozatok sajátos helyszínei közé tartozik, a fiatalok közel fele az elmúlt évben részt vett valamilyen fesztiválon. A fiatalok jóval magasabb arányban járnak könnyüzenei koncertekre és fesztiválokra, kialakulóban van egy úgynevezett fesztiválkultúra, a fiatalok egy szegmense megalapozottan tekinthető a fesztiválok ifjúságának (Ercsei 2006; Veres 2006; Ercsei-Kiss-Szabó 2011; Szabó-Hires-László 2018). A fesztiválozók fogyasztói profilja, kulturális fogyasztási szokásai igencsak összetettek: „Az ország össznépességéhez képest sokkal nagyobb mértékben követik a középosztályi mintákat, ám korántsem mondható el, hogy egységes kulturális profil jellemezné őket” (Veres 2006).

${ }^{48}$ Az ifjúságkutatás egyik sajátos terepe, az ifjúsági fesztiválokon végzet kérdőíves felmérések. Gábor Kálmán kezdeményezésével indult 1999-ben a Sziget kutatás, és ezt követően több más terepen hasonló jellegü ifjúságszociológiai felmérések zajlottak. (Budapest Parádé, Sport-sziget, Tusványos 2001, Félsziget 2005-2013, Electric Castle 2016-2017) 
Etnikai vonatkozásban a szembetűnő különbség a romániai magyar és a romániai román fiatalok között a „színházak/hangversenyek látogatottsága”, illetve a „kirándulások" tekintetében vannak. A magyar fiatalok nagyobb arányban és gyakrabban látogatják ezen kulturális eseményeket, mint a román fiatalok, hasonlóképpen jóval kedveltebb szabadidős tevékenység a kirándulás a magyarok körében. A két etnikum eltérő intenzitású fogyasztói mintázata arra vezethető vissza, hogy az erdélyi magyarok a magyarországi, illetve a romániai kulturális habitusok között helyezkednek el (Barna 2011).

\section{7. Összefoglalás}

Összefoglalva az erdélyi magyar fiatalok szocio-demográfiai jellemzőit, az első lényeges észrevétel a fiatalok körében 2001 és 2016 között, hogy az ország népességfogyása jelentősen érintette a magyar népességet is, különösen a 15-29 éves fiatalok száma csökkent.

A fiatalok iskolai végzettségét vizsgálva pozitív tendenciánk lehetünk tanúi, a felsőoktatásban részt vevők aránya növekedett, egyre több fiatalnak van magasabb iskolai végzettsége a szülei (apa) iskolai státusánál. Tehát a felsőoktatás expanziója növelte a felsőoktatásban részt vevő fiatalok arányát. Az oktatási rendszer minden szintjén markáns különbségek figyelhetők meg a férfiak és a nők iskolázottsága között. A nők aránya különösen a felsőoktatásban emelkedett meg, a férfiak a szakiskolát végzettek kategóriában haladják mg a nők arányát. Mindkét évben szignifikáns öszszefüggés van az apa iskolai végzettsége és a megkérdezett fiatal iskolai végzettsége között.

A lakhely településtípusa is hatással van a továbbtanulás mértékére, tehát a társadalmi egyenlőtlenségek kérdése az iskolai végzettség és településtípus összefüggéseiben is megmutatkoznak, viszont ezek a különbségek mintha mérséklődtek volna az évek során.

Az anyagi helyzetet vizsgálva megállapíthatjuk, hogy a fiatalok relatív jóléte jelentősen emelkedett, viszont inkább egy általános életszínvonalbeli javulásról van szó, mintsem az egyenlőtlenségek csökkenéséről. Az apa iskolai végzettsége és foglalkozása, valamint a fiatalok jóléti percepciója között szintén pozitív szignifikáns kapcsolat van. 
A fiatalok foglalkozási struktúráját vizsgálva az össznépességhez hasonló változásokat állapíthatunk meg: csökkent a munkanélküliek aránya, kevesebb a fiatalok között a szakképzetlen/fizikai munkás és gazdálkodó, nagyobb arányban vannak vállalkozók, illetve vezetők. Az apa iskolai végzettsége és foglalkozása, illetve a megkérdezett fiatalok foglalkozási szerkezete szintén szignifikáns összefüggésekre utalnak, ami a vertikális differenciálódást vetítik elő. Minél magasabb az apa iskolai végzettsége, annál valószínűbb, hogy a megkérdezett fiatal vállalkozó vezető vagy értelmiségi foglalkozással rendelkezik, illetve az általános/szakiskolai végzettségü szülök gyerekei inkább szakmunkások.

Elemzésünk fontos részét képezi a kulturális fogyasztás, ezt vizsgálva az derül ki, hogy a magyar fiatalok kulturális fogyasztás tekintetében igencsak alacsony aktivitást mutatnak, különösen a magaskultúrát megjelenítő színterek, mint a színház, kiállítások és múzeumok látogatottsága mutat csökkenő tendenciát. A fiatalok szabadidős és kulturális fogyasztásának befolyásoló tényezőit, egy következő fejezetben részletesebben is tárgyaljuk. 


\section{A státushelyzet társadalmi meghatározói}

\subsection{Bevezetés}

A fiatalok társadalmi hierarchiában való elhelyezkedésének leírásához két nagymintás ifjúságkutatás adatait használjuk fel, a MOZAIK 2001, illetve a Magyar Ifjúság Kutatás 2016-os felmérés eredményeit.

Mind a nemzetközi, mind a hazai rétegződéskutatásban jelentős hagyománya van az olyan státuszindex készítésének, amelyek több vertikális dimenzió mentén méri a társadalmi státuszt (Fábián-Róbert-Szívós 1998; Veres 2014). Azt vizsgáljuk, hogy hogyan magyarázzák a státushelyzetet a különböző szocio-demográfiai jellemzők.

\subsection{A státushelyzet társadalmi meghatározói. MOZAIK 2001}

A fiatalok rétegződésének leírására egy összetett mutatót hoztunk létre. Mivel a társadalmi státusz közvetlen nem mérhető, olyan változókat választottunk ki, amelyek szorosan összefüggenek a státusszal. A státusindex szerkesztésekor figyelembe vettük Fábián-Kolosi-Róbert (Fábián-Kolosi-Róbert 2000; Kolosi-Róbert 2004) és Veres (Veres 2014) hasonló index készítési módszertanát, azonban a kérdőív adta korlátok miatt adott esetben más-más dimenziókat kellett figyelembe vennünk (pl. az anyagi fogyasztási összetevőknél).

A státusindexet a következő dimenziókból hoztuk létre: (1) lakáskörülmények, (2) anyagi-vagyoni helyzet és (3) szabadidő fogyasztása. A jövedelmet kihagytuk az elemzésből, ugyanis a megkérdezett fiatalok mindössze fele dolgozik, és ezen fiatalok közül is hozzávetőlegesen 70 százalék válaszolt a jövedelmi kérdésre. A státusindex 
dimenzióinak összetevőit Z-szkórral standardizáltuk. A standardizálás célja a bemeneti változók tartományának egységesítése, hogy mindegyik egyformán járuljon hozzá az elemzéshez. Matematikailag ez azt jelenti, hogy kivonjuk az átlagot és elosztjuk az egyes változók minden egyes értékének szórásával. Ha nagy különbségek vannak a kezdeti változók tartományai között, akkor a nagyobb tartományokkal rendelkező változók dominálnak a kis tartományúakkal szemben ${ }^{49}$, amely torzítja az eredményeket.(Jaadi 2020)

A lakáskörülmények indikátorai a lakás négyzetméterére és infrastruktúrájára ${ }^{50}$ vonatkozó adatok. A lakás négyzetméterét elosztottuk a háztartásban élők számával ${ }^{51}$. Az anyagi vagyoni helyzet összetevőit - tartós használati cikkeket, mint színes tévé, automata mosógép, mosogatógép, CD-lejátszó, számítógép, vezetékes telefon, mobiltelefon, mélyhütő, nyaraló, másik lakóingatlan, építési telek, személygépkocsi - egyszerü összeadással kumuláltuk egy diszkrét változóba. A szabadidő index esetében figyelembe vettük, hogy az elmúlt egy évben kifejezetten turisztikai céllal utazott-e más országokban, illetve, hogy hány könyvet olvasott. Továbbá a 11 szabadidős tevékenység $^{52}$ gyakorisága alapján szintén létrehoztunk egy kumulált indexet. Ezt követően az egyes dimenziók összetevőiből (az alapindexekből: lakáskörülmények, anyagi-vagyoni helyzet, illetve szabadidő index) fökomponens-elemzéssel létrehoztunk egy státusmérő indexet.

\section{1. táblázat: A fökomponens eredményei, a státusindex-komponens súlyértékei}

\begin{tabular}{|l|c|}
\hline \multicolumn{1}{|c|}{ Összetevök } & \\
\hline Lakáskörülmények & .805 \\
\hline Anyagi-vagyoni helyzet & .837 \\
\hline Szabadidö index & .723 \\
\hline Magyarázott összvariancia & 62.3 \\
\hline KMO & .646 \\
\hline
\end{tabular}

\footnotetext{
${ }^{49}$ Például egy 10 és 200 közötti változó (lakás négyzetmétere) dominál a 0 és 1 közötti változó (volt-e nyaralni) felett.

${ }^{50}$ WC, vezetékes víz, vezetékes gáz, saját hőközpont, állandó melegvízellátás villany, szennyvízelvezető csatorna

${ }^{51}$ A lakás méretére vonatkozó hiányzó válaszokat kiegészítettük az érvényesen kapott válaszok alapján kiszámított átlagos szobaszámnak megfelelő átlagos alapterülettel, különböző szobaszámú lakások szerint.

52 színház, mozi, könyvtár, könnyüzenei koncert, diszkó, hangversenyen, könyvesbolt, müvelödési ház, bál, házibuli, kiállítás
} 
A fökomponens-elemzés eredményeként kapott új változó az összvariancia 62 százalékát magyarázza. A Kaiser-Meyer-Olkin (KMO) $)^{53}$ 0,65-ös értéke alapján adataink alkalmasak főkomponens elemzésre. A komponenssúlyértékek alapján a legmagasabb értéke az anyagi vagyoni helyzetnek van, de a három státusmérő index súlyértéke kiegyensúlyozott.

\subsection{A társadalmi státushelyzet meghatározásának modelljei: lineáris regresszió}

A továbbiakban arra keressük a választ, hogy milyen társadalmi meghatározói vannak az ismertetett három összetevőből létrehozott státusindexnek (lakáskörülmények, anyagi-vagyoni helyzet és szabadidős index), erre egy lineáris regressziós modellt építünk. A modellbe bevont független változók: nem, életkor, iskolázottság, településtípus, apa iskolai végzettsége, apa foglalkozása és a megkérdezett státusa (tanul, dolgozik vagy egyik sem). Az elemzést egymásba ágyazott modellek becslésével végeztük. Az első modellbe csak a szocio-demográfiai változók kerültek be a nem, életkor, településtípus és iskolai végzettség, így a modell magyarázóereje 0.351. A második modellbe bevontuk az apa iskolai végzettségét, illetve az apa foglalkozását, így a modell magyarázó értéke 0.406-ra nőtt. Végül a harmadik modellt tovább bővítettük a megkérdezett státusával (dolgozik, tanul vagy egyik sem).

Az eredményeket a 7.2. táblázat tartalmazza, ami alapján azt láthatjuk, hogy az egyetemi végzettségnek van a legerősebb hatása (0,394 és 0,222 béta értékkel), de a fiatalok saját, és az apák iskolai végzettsége is egyaránt befolyásolja a státust. Továbbá szignifikáns kapcsolatot mutat a településtípus, de negatívan befolyásolja azt, ha valaki falun $(0,391)$ vagy kisvárosban $(0,145)$ lakik. Az életkor és a nem kisebb béta értékkel rendelkezik, de szintén szignifikáns. Első látásra kissé meglepő eredmény, hogy az életkor negatív hatással van a státusra, ez feltételezéseink szerint annak köszönhető, hogy a fiatalok, ameddig a szülőkkel egy háztartásban élnek, mind anyagilag, mind pedig szabadidős tekintetben egy stabilabb pozícióban vannak. Emellett pedig

${ }^{53}$ A Kaiser-Meyer-Olkin (KMO) egyik legfontosabb mérőszám annak megítélésében, hogy a változók mennyire alkalmasak a faktoranalízisre. A Kaiser-Meyer-Olkin mérték számításakor az egész minta megfelelőségét (MSA: Measure of Sampling Adequacy) vizsgáljuk. A KMO értéke 0,6 érték felett megfelelőnek bizonyul, a változók alkalmasak a faktoranalízisre. (Kovács, 2014) 
feltételezhetően azok kezdenek el korábban dolgozni, akiknek a szülöi háttere anyagi értelemben szerényebb. Az apa foglalkozása nincs jelentős hatással a státusra, csak a vállalkozói státussal rendelkezők esetében mutatható ki enyhébb szignifikáns összefüggés $(0,105)$.

7.2. táblázat: A fiatalok státushelyzetét magyarázó lineáris regresszió együtthatói. Mozaik 2001 (OLS regressziós modell)

\begin{tabular}{|c|c|c|c|c|c|}
\hline $\begin{array}{l}\text { Független változók } \\
\text { MOZAIK } 2001\end{array}$ & 1. modell & 2. modell & 3. modell & 4. modell & 5. modell \\
\hline & & & & Tanul & Dolgozik \\
\hline \multicolumn{6}{|l|}{ Neme } \\
\hline Nő & $\begin{array}{l}-.075 \\
(.003)\end{array}$ & $\begin{array}{l}-.046 \\
(.142)\end{array}$ & $\begin{array}{l}-.045 \\
(.153)\end{array}$ & $\begin{array}{l}-.045 \\
(.154)\end{array}$ & $\begin{array}{l}-.007 \\
(.183) \\
\end{array}$ \\
\hline Életkora & $\begin{array}{l}-.153 \\
(.000)\end{array}$ & $\begin{array}{l}-.081 \\
(.023)\end{array}$ & $\begin{array}{l}.032 \\
(.421)\end{array}$ & $\begin{array}{l}.208 \\
(.000)\end{array}$ & $\begin{array}{l}.163 \\
(.143)\end{array}$ \\
\hline \multicolumn{6}{|l|}{ Iskolai végzettség } \\
\hline Elméleti líceum, fóiskola & $\begin{array}{l}.297 \\
(.000)\end{array}$ & $\begin{array}{l}.237 \\
(.000)\end{array}$ & $\begin{array}{l}.232 \\
(.000)\end{array}$ & & $\begin{array}{c}.301 \\
(.000) \\
\end{array}$ \\
\hline Egyetem, magiszteri, $\mathrm{PhD}$ & $\begin{array}{l}.394 \\
(.000)\end{array}$ & $\begin{array}{l}.307 \\
(.000)\end{array}$ & $\begin{array}{l}.298 \\
(.000)\end{array}$ & & $\begin{array}{r}.452 \\
(.000)\end{array}$ \\
\hline \multicolumn{6}{|l|}{ Településtípus } \\
\hline Más város & $\begin{array}{l}-.145 \\
(.000)\end{array}$ & $\begin{array}{l}-.130 \\
(.000)\end{array}$ & $\begin{array}{l}-.115 \\
(.000)\end{array}$ & $\begin{array}{l}-.188 \\
(.003)\end{array}$ & $\begin{array}{l}-.151 \\
(.000)\end{array}$ \\
\hline Falu & $\begin{array}{l}-.391 \\
(.000)\end{array}$ & $\begin{array}{l}-.336 \\
(.000)\end{array}$ & $\begin{array}{l}-.291 \\
(.000)\end{array}$ & $\begin{array}{l}-.226 \\
(.000)\end{array}$ & $\begin{array}{l}-.315 \\
(.000)\end{array}$ \\
\hline \multicolumn{6}{|l|}{ Apa Iskolai végzettsége } \\
\hline Elméleti líceum, főiskola & & $\begin{array}{l}.155 \\
(.000)\end{array}$ & $\begin{array}{l}.136 \\
(.000)\end{array}$ & $\begin{array}{l}.280 \\
(.000)\end{array}$ & $\begin{array}{l}.102 \\
(.005)\end{array}$ \\
\hline Egyetem, magiszteri, $\mathrm{PhD}$ & & $\begin{array}{l}.222 \\
(.000)\end{array}$ & $\begin{array}{l}.207 \\
(.000)\end{array}$ & $\begin{array}{l}.309 \\
(.000)\end{array}$ & $\begin{array}{l}.163 \\
(.000)\end{array}$ \\
\hline \multicolumn{6}{|l|}{ Apa Foglalkozása } \\
\hline alkalmazott & & $\begin{array}{l}.048 \\
(.188)\end{array}$ & $\begin{array}{c}.028 \\
(.433)\end{array}$ & $\begin{array}{l}.095 \\
(.283)\end{array}$ & $\begin{array}{l}-.022 \\
(.183) \\
\end{array}$ \\
\hline vállalkozásban dolgozik & & $\begin{array}{l}.105 \\
(.002)\end{array}$ & $\begin{array}{l}.087 \\
(.008)\end{array}$ & $\begin{array}{l}.210 \\
(.001)\end{array}$ & $\begin{array}{l}.019 \\
(.083) \\
\end{array}$ \\
\hline $\begin{array}{l}\text { gazdaságban dolgozik, alkalmi } \\
\text { munkából él }\end{array}$ & & $\begin{array}{l}.034 \\
(.300) \\
\end{array}$ & $\begin{array}{c}.030 \\
(.346) \\
\end{array}$ & $\begin{array}{c}.092 \\
(.433) \\
\end{array}$ & $\begin{array}{c}.002 \\
(.286) \\
\end{array}$ \\
\hline egyéb & & $\begin{array}{l}-.029 \\
(.372) \\
\end{array}$ & $\begin{array}{l}-.016 \\
(.611) \\
\end{array}$ & $\begin{array}{l}.129 \\
(.005) \\
\end{array}$ & $\begin{array}{l}-.045 \\
(.182) \\
\end{array}$ \\
\hline \multicolumn{6}{|l|}{ Mivel foglalkozik jelenleg } \\
\hline Tanul & & & $\begin{array}{l}.192 \\
(.000) \\
\end{array}$ & & \\
\hline egyéb & & & $\begin{array}{l}-.110 \\
(.000) \\
\end{array}$ & & \\
\hline Korrigált R-négyzet & .351 & .406 & .450 & .305 & .324 \\
\hline $\mathrm{N}$ & 763 & 655 & 617 & 200 & 330 \\
\hline
\end{tabular}

Függő változó: Státusindex Kontrollváltozók: Férfi, általános iskola/szakiskola, megyeszékhely, apa iskolai végzettsége - általános iskola/szakiskola, apa foglalkozása - gazdaságilag inaktív

Ezt követően a regressziót külön-külön elvégeztük a „tanulókra” (4. modell), illetve a „dolgozókra” (5. modell) is. Bár az esetszám alacsony, a magyarázó erő viszonylag magas maradt (az R-négyzet értéke 0.305, illetve 0.324), az apa foglalkozása 
ebben az esetben sem mutat jelentős hatást. A dolgozók esetében viszont azt láthatjuk, hogy a felsőfokú végzettség még erősebben hat a státusra.

\subsection{A státushelyzet társadalmi meghatározói. Magyar Ifjúság Kutatás 2016}

A 2016-os felmérés esetében hasonló módszerrel vizsgáltuk meg a státushelyzetet magyarázó szocio-demográfiai tényezőket. A státusindex dimenziói ez esetben is a lakáskörülmény, anyagi vagyoni helyzet, és szabadidő fogyasztása voltak. A változókat szintén Z-szkórral standardizáltuk.

Mivel a lakás infrastruktúrájára és négyzetméterére vonatkozó adatok hiányoznak a kérdőívből, az alábbi lakáskörülményekre vonatkozó kérdéseket vettük figyelembe: (1) Jellemezd a lakást - 5 pontos skála mérte az alábbi dimenziókat (sötétvilágos, elhanyagolt-ápolt, szük-tágas, régi építésü-új építésü). (2) A ház helye a településen belül ${ }^{54}$ (olcsó lakáspiaci övezet, közepes átlagos lakáspiaci övezet, helyileg magasabbra értékelt lakáspiaci övezet, helyileg a legmagasabbra értékelt lakáspiaci övezet).

A 2016-os felmérésben nem kérdeztek rá a tartós használati cikkekre, ezért az anyagi vagyoni helyzet összetevőket egyrészt (1) a médiaeszközökkel való felszereltséggel mértük (saját: okostelefon, okostelefonon internet-előfizetés, számítógépe, laptopja, tabletje, játékkonzolja, okosóra-aktivitásmérö, bankszámlája, bankkártyája, életbiztosítása, megtakarított pénze), másrészt (2) egy szubjektív vagyoni helyzetet mérő kérdést is bevontunk az elemzésbe: összességében hogy érzi magát anyagilag (gondok nélkül élnek; beosztással jól kijönnek; éppen, hogy kijönnek a jövedelmükből; hónapról-hónapra anyagi gondjaik vannak; nélkülözések között élnek).

A szabadidő index esetében a 2001-es adatokhoz hasonló dimenziókat vettük figyelembe: az elmúlt egy évben volt-e nyaralni (legalább két éjszakát ott töltött), illetve, hogy hány darab hagyományos (nyomtatott) könyv van a háztartásban. Továbbá a 15 szabadidős tevékenység ${ }^{55}$ gyakorisága alapján szintén létrehoztunk egy kumulált indexet.

\footnotetext{
54 A kérdezőbiztosok feladata volt annak eldöntése, hogy az általuk felkeresett háztartásnak milyen a lakáspiaci státusza, vagyis olcsó, közepes vagy drágának ítéli a környéken található ingatlanokat, lakásokat

55 (színház, art mozi, multiplex mozi, könyvtár, hangverseny, könnyüzenei koncert, könyvesbolt, kiállítás-múzeum, opera, kávéház-teázó, söröző-borozó, étterem, konditerem, pláza, táncház)
} 
A három bemutatott dimenzió mentén hasonló módszert alkalmazva létrehoztunk egy, az előzőhöz hasonló státusindexet. A főkomponens-elemzés eredményeként kapott új változó az összvariancia ${ }^{56} 43$ százalékát magyarázza, a KMO értéke 0,65 . A társadalomtudományokban az elfogadott varianciahányad 60\% (Sajtos-Mitev 2007), de egyes kutatók szerint akkor is elfogadhatunk egy fökomponenst, ha benne megörződik a teljes változóérték információjának legalább a fele (Székely-Barna 2002). Ezt a szabályt annál szigorúbban kell vennünk, minél kevesebb mért változót aggregálunk. Mivel ragaszkodtunk ahhoz, hogy hasonló változók kerüljenek be a státusindexbe, ügy döntöttünk, hogy elfogadjuk a 43 százalékot, szem elött tartva azt is, hogy valószínüsíthetően a sokféle változó aggregálása miatt lett kisebb az érték. A KMO mutató értéke: 0,65 , ami közepes modellt jelez, és a kommunalitások ${ }^{57}$ is magasak. Az így létrejött négy státusmérő index súlyértéke kiegyensúlyozott, legmagasabb értéke a lakáskörülménynek van.

\section{3. táblázat: A fókomponens eredményei, a státusindex-komponens súlyértékei}

\begin{tabular}{|l|c|}
\hline \multicolumn{1}{|c|}{ Összetevők } & \\
\hline Lakáskörülmények & .731 \\
\hline A ház helye a településen belül & .645 \\
\hline Önök anyagilag & .656 \\
\hline Szabadidő index & .578 \\
\hline Magyarázott összvariancia & 42.8 \\
\hline KMO & .652 \\
\hline
\end{tabular}

\subsection{A társadalmi státushelyzet meghatározásának modelljei: lineáris regresszió}

A modellt több lépcsőben is megbecsültük, az első modellben a megszokott szocio-demográfiai változókkal (nem, életkor, településtípus és iskolai végzettség), az így kapott modell magyarázóereje 0,102. Második lépésben bevontuk az apa iskolai végzettségét és foglalkozását, ezzel a modell magyarázó értéke 0,165-re nőtt; végül a harmadik modellbe beléptettük a megkérdezett státusát is (dolgozik-tanul vagy egyik sem), lásd a 7.4. táblázatot.

\footnotetext{
${ }^{56}$ A varianciahányad módszer a gyakorlati szignifikancián alapul, minél magasabb a varianciahányados, annál nagyobb információ őrződik meg az elemzés során. A társadalomtudományokban az elfogadott varianciahányad $60 \%$.

${ }^{57}$ Egy-egy sor elemeinek négyzetösszege a változónak a fökomponensek által megmagyarázott varianciája. Ha a kommunalitás kisebb, mint 0,25 , akkor a változó egyetlen faktorral sem korrelál. A kommunalitás többszörös determinációs együtthatóként értelmezhető. (Kovács, 2014)
} 
7.4. táblázat: A fiatalok státushelyzetét magyarázó lineáris regresszió együtthatói. Ifjúság 2016 (OLS regressziós modell)

\begin{tabular}{|c|c|c|c|c|c|}
\hline $\begin{array}{c}\text { Független változók } \\
\text { Magyar Ifjúság Kutatás } 2016\end{array}$ & 1. modell & 2. modell & 3. modell & 4. modell & 5. modell \\
\hline & & & & Tanul & Dolgozik \\
\hline \multicolumn{6}{|l|}{ Neme } \\
\hline Nö & $\begin{array}{l}.031 \\
(.269)\end{array}$ & $\begin{array}{l}.042 \\
(.142)\end{array}$ & $\begin{array}{l}.052 \\
(.083)\end{array}$ & $\begin{array}{l}-.046 \\
(.259)\end{array}$ & $\begin{array}{l}.075 \\
(.085)\end{array}$ \\
\hline Életkora & $\begin{array}{l}-.314 \\
(.000)\end{array}$ & $\begin{array}{l}-.235 \\
(.000)\end{array}$ & $\begin{array}{l}-.087 \\
(.073)\end{array}$ & $\begin{array}{c}.052 \\
(.251)\end{array}$ & $\begin{array}{c}.068 \\
(.128)\end{array}$ \\
\hline \multicolumn{6}{|l|}{ Iskolai végzettség } \\
\hline Elméleti líceum, föiskola & $\begin{array}{c}.210 \\
(.000) \\
\end{array}$ & $\begin{array}{c}.166 \\
(.000) \\
\end{array}$ & $\begin{array}{c}.135 \\
(.000) \\
\end{array}$ & & $\begin{array}{c}.193 \\
(.000) \\
\end{array}$ \\
\hline Egyetem, magiszteri, $\mathrm{PhD}$ & $\begin{array}{c}.292 \\
(.000) \\
\end{array}$ & $\begin{array}{c}.224 \\
(.000) \\
\end{array}$ & $\begin{array}{c}.209 \\
(.000) \\
\end{array}$ & & $\begin{array}{c}.334 \\
(.000) \\
\end{array}$ \\
\hline \multicolumn{6}{|l|}{ Településtípus } \\
\hline Más város & $\begin{array}{c}.057 \\
(.091) \\
\end{array}$ & $\begin{array}{c}.090 \\
(.009) \\
\end{array}$ & $\begin{array}{c}.108 \\
(.002) \\
\end{array}$ & $\begin{array}{c}.145 \\
(.001) \\
\end{array}$ & $\begin{array}{l}.-090 \\
(.083) \\
\end{array}$ \\
\hline falu & $\begin{array}{c}.003 \\
(.933) \\
\end{array}$ & $\begin{array}{c}.097 \\
(.008) \\
\end{array}$ & $\begin{array}{c}.117 \\
(.002) \\
\end{array}$ & $\begin{array}{c}.090 \\
(.088) \\
\end{array}$ & $\begin{array}{c}.-186 \\
(.002) \\
\end{array}$ \\
\hline \multicolumn{6}{|l|}{ Apa Iskolai végzettsége } \\
\hline Elméleti líceum, főiskola & & $\begin{array}{c}.184 \\
(.000) \\
\end{array}$ & $\begin{array}{c}.171 \\
(.000) \\
\end{array}$ & $\begin{array}{c}.163 \\
(.001) \\
\end{array}$ & $\begin{array}{c}.151 \\
(.001) \\
\end{array}$ \\
\hline Egyetem, magiszteri, $\mathrm{PhD}$ & & $\begin{array}{c}.176 \\
(.000) \\
\end{array}$ & $\begin{array}{c}.152 \\
(.000) \\
\end{array}$ & $\begin{array}{c}.184 \\
(.003) \\
\end{array}$ & $\begin{array}{c}.090 \\
(.097) \\
\end{array}$ \\
\hline \multicolumn{6}{|l|}{ Apa Foglalkozása } \\
\hline szellemi & & $\begin{array}{c}.006 \\
(.850) \\
\end{array}$ & $\begin{array}{c}.007 \\
(.851) \\
\end{array}$ & $\begin{array}{l}.011 . \\
(.833) \\
\end{array}$ & $\begin{array}{c}.038 \\
(.458) \\
\end{array}$ \\
\hline vezető & & $\begin{array}{c}.129 \\
(.000) \\
\end{array}$ & $\begin{array}{c}.121 \\
(.000)\end{array}$ & $\begin{array}{c}.154 \\
(.003)\end{array}$ & $\begin{array}{c}.092 \\
(.043)\end{array}$ \\
\hline \multicolumn{6}{|l|}{ Mivel foglalkozik jelenleg } \\
\hline Tanul & & & $\begin{array}{c}.156 \\
(.000) \\
\end{array}$ & & \\
\hline egyéb & & & $\begin{array}{l}-067 \\
(.026)\end{array}$ & & \\
\hline Korrigált R-négyzet & .102 & .165 & .165 & .082 & .148 \\
\hline $\mathrm{N}$ & 1162 & 1043 & 1014 & 490 & 470 \\
\hline
\end{tabular}

Függő változó: státusindex. Kontrollváltozók: Férfi, általános iskola/szakiskola/szakközépiskola, megyeszékhely, apa iskolai végzettsége - általános iskola/szakiskola/szakközép, apa foglalkozása - fizikai.

A regressziós modell alapján 2016-ban is az egyetemi végzettségnek van a legerősebb hatása ( 0,292 és 0,176 béta értékkel), a fiatalok saját, illetve az apa iskolai végzettsége egyaránt szignifikáns összefüggést mutat. 2001-hez képest a településtípus nem befolyásolja a státust, az életkor viszont nagyobb hatást fejt ki, negatív elöjellel. Az apa foglalkozása hasonlóképpen csak a vezetők esetében szignifikáns (0,129 és béta értékkel).

A 4. és 5. modellben megvizsgáltuk, hogy hogyan hatnak a magyarázó változóink külön-külön a tanulókra, illetve a dolgozókra. A dolgozók esetében szintén 
erősebb kapcsolat van a végzettség és a státus között, különösen az egyetemi végzettség befolyásolja a státust. Az apa iskolai végzettsége és a tanuló fiatalok státusa között szignifikáns összefüggés van, azonban a dolgozó fiatalokat vizsgálva az apa foglalkozása továbbra is csak a vezetők estében mutat szignifikáns összefüggést.

\section{6. Összefoglalás}

Jelen fejezetben azt vizsgáltuk, hogy milyen tényezők határozzák meg a 15-29 éves korosztály státushelyzetét 2001 és 2016 között. Arra voltunk kíváncsiak, hogy milyen hatással van a fiatalok státusára a származás (apa iskolai végzettsége, foglalkozása). Figyelembe véve a Tárki-kutatások (Kolosi-Róbert 2004) és (Veres 2014) feldolgozása során használt indexépítési technikát, főkomponens elemzéssel egy státusmérő indexet hoztunk létre a lakáskörülmények, anyagi vagyoni helyzet, és szabadidő fogyasztás változók bevonásával.

A társadalmi státushelyzetet magyarázó tényezők közül a regressziós modellek alapján mindkét évben az iskolai végzettség, különösen a felsőfokú végzettség a legfontosabb. A fiatalok státusát az apa iskolai végzettsége befolyásolja, az apa foglalkozásának viszont csak a vezetők esetében van szignifikáns kapcsolata.

A településtípus és státus között csupán 2001-ben mértünk statisztikai összefüggést. Az életkor és a nem kisebb mértékben ugyan, de szintén szignifikáns összefüggést mutat a társadalmi státushelyzetre. A fiatalabbak és a nők mind anyagilag, mind pedig szabadidős tekintetben egy stabilabb pozícióban vannak. Feltételezhetően a szülőkkel még egy háztartásban élők anyagilag még biztonságban érzik magukat.

A státushelyzet társadalmi meghatározóit vizsgálva azt mondhatjuk, hogy az apa foglalkozása nem annyira meghatározó a fiatalok státusában, az iskolai végzettség azonban változatlanul fontos marad, a kulturális tőke továbbra is a legfontosabb státusmeghatározó tényezö.

Eredményeink Treiman modernizációs tézisével is megegyeznek, miszerint az iskolai végzettségnek a foglalkozásra gyakorolt hatása erősebb, míg az apa foglalkozásának szerepe csökkent. ${ }^{58}$

${ }^{58}$ Németh (2006) szerint Magyarországon Treiman hipotézisével ellentétes tendenciák figyelhetők meg. A szülöi háttér hatása a fiúk iskolázottságára folyamatosan erősödik, sőt a származás az iskolarendszert megkerülve, más csatornákon keresztül is befolyásolja az elért státuszt. 
A státushelyzet egyik legmeghatározóbb tényezője az iskolai végzettség, a Bourdieu-i illetve Zinnecker-i megközelítés szerint minél több ideje van egy fiatalnak arra, hogy kulturális tőkére tegyen szert, azaz minél előnyösebb családi hátérrel rendelkezik, annál jobb helyzetbe kerül. Azt is mondhatnánk, hogy az ifjúság a szülői osztályhelyzet szerint szegmentálódik (Zinnecker 2006), azonban ez az állítás nem állja meg a helyét, amennyiben az osztályhelyzet alatt a szűkebb értelemben vett „,foglalkozási osztályszerkezetet" értjük.

A fiatalok esetében elsősorban az apa foglalkozásának hatását próbáltuk mérni, ugyanis még abban az életkorban vannak, amikor nagyrészük inaktív, viszont elemzésünk azt mutatja, hogy az apa foglalkozásának hatása nem annyira releváns. A fiatalok esetében különösen érvényesnek bizonyul az az állítás miszerint a foglalkoztatási aggregátum alkalmazásával nem lehet minden osztályalapú problémát feltárni (Crompton-Scott 2014). Azt láthatjuk, hogy nem, vagy csak nehézségek árán alkalmazhatók a hagyományos foglalkozás alapú megközelítések a fiatalok esetében.

A foglalkozásszerkezeti megközelítéssel ugyan jól megkülönböztethetőek a pozíciók a munkaerőpiacon, de érvényességével kapcsolatosan az a reális ellenérv is tapasztalható, hogy az elmúlt évtizedekben jelentősen megnőtt azok aránya, akiknek nincsen vagy megváltozott a „munkajellegük”. Az ifjúsági korszakváltás azt eredményezte, hogy a fiatalok egyre később kerülnek be a munkaerőpiacra, illetve, ha bekerülnek is ezek egyre hektikusabbá válnak. Úgy gondoljuk, hogy a foglalkozásalapú megközelítések mellé, különösen a fiatalok vizsgálata esetében fokozatosan be kell vonni más stratifikációs tényezőket: életmód, fogyasztás, kapcsolatok, kultúra dimenziója.

A következő fejezetben a kulturális fogyasztásban megmutatkozó jellegzetességetek vizsgáljuk. 


\section{Kulturális szegmentáció}

\section{az erdélyi magyar fiatalok körében}

\subsection{Bevezetés}

Az előző fejezetben a rétegződés hagyományos megközelítése szerint jellemeztük a fiatalok társadalmi pozícióját: először gazdasági aktivitásuk, illetve munkaerőpiaci jellemzőik alapján, majd megvizsgáltuk, hogyan magyarázzák a társadalmi státushelyzetet a különböző szocio-demográfiai tényezők. Az új rétegződési diskurzusban azonban az a kérdés is felmerül, hogy vajon mennyire alkalmasak az egyenlötlenségek vizsgálatára a 21 . századi posztindusztriális társadalomban a hagyományos, foglalkozás-, iskolázottság- és jövedelemalapú megközelítések. A társadalmi rétegződés vizsgálatával foglalkozó kutatók körében egyre gyakrabban felmerül az igény, hogy a rétegződéskutatás „,határait szélesebbre kellene nyitni”. Különösen a fiatal korosztályok egyenlőtlenségének vizsgálatában fontos a fogyasztás szerepének bevonása, ugyanis a fogyasztói társadalom kialakulása különösen a fiatalok életmódját érinti hangsúlyosan. Minél nagyobb a fogyasztási kényszer, a fiatalok társadalmi pozíciója annál inkább a fogyasztás révén fejeződik ki, ez jelentős strukturális változásokat eredményez.

Jelen fejezetben a kulturális fogyasztásban mutatkozó társadalmi különbségeket vizsgáljuk. Arra keressük a választ, hogy: (1) Milyen kulturális fogyasztásbeli jellegzetességek alapján különülnek el az erdélyi magyar fiatalok? (2) Milyen tényezők befolyásolják a kulturális fogyasztási szokásaikat? (3) Mennyire érvényes körükben az a megközelítés, mely szerint a „kulturális mindenevőség” felbukkanása feloszlatja az osztályalapú megkülönböztetést a kulturális fogyasztás tekintetében?

Már Veblen (1975) és Bourdieu (1984) is rávilágított arra, hogy a fogyasztásnak kiemelt helye van a társadalmi viszonyok fenntartásában és megváltoztatásában. A meghosszabbodott ifjúsági életszakaszban különösen fontos szerepet kapnak azok a tevékenységek, amelyek a szabadidöhöz és a fogyasztói kultúrához kötődnek (Zinnecker 1993; Gábor 2004; Ercsei-Kiss-Szabó 2011; Fekete 2018; Szabó-Hires- 
László 2018). Napjainkban a szabadidős terep a családdal és az iskolával egyenrangú szocializációs ágensként jelenik meg, nem magát az időt, hanem annak felhasználását jelenti. A szórakozás és feltöltődés funkciója mellett az önkifejezés, önmegvalósítás funkcióját is betölti. (Nagy-Fazekas 2016)

A fogyasztás szorosan összefügg a társadalmi rétegződéssel. Az úgynevezett szolgáltató-információs társadalomban az anyagi és kulturális fogyasztás a társadalmi rétegződés legfontosabb összetevői (Róbert 1999; Fábián-Kolosi-Róbert 2000), és míg a hagyományos rétegződési vizsgálatok viszonylag alacsony társadalmi különbségeket tárnak fel, addig az életstílus-vizsgálatok a társadalmi egyenlötlenségek újratermelésének jellegzetes formáiról számolnak be (Róbert 1999).

Jörg Rössel (2005) amellett érvel, hogy több egyenrangú strukturáló erő fejti ki hatását, az osztálystruktúrák, az életstílusok és a hálózati miliők egymással egyenrangú strukturáló tényezői lehetnek a modern társadalomnak. A társadalom lényegében annyi szempont szerint tagolható csoportokra, ahány ilyen mezőt a kutató megállapított. Véleménye szerint mindegyik tényezőnek szignifikáns strukturáló hatása van bármelyik másikra, nem lehet egyik tényezőt sem abszolutizálni (Rössel 2005; Berger 2013).

Mi is egy többdimenziós tagozódási modell mellett érvelünk, amelyben a fogyasztásnak fontosabb stratifikációs jelentőséget tulajdonítunk. A következő fejezet a kulturális fogyasztásban megmutatkozó társadalmi különbségeket vizsgálja, elemzésünkben a szabadidős/kulturális fogyasztás és a társadalmi rétegződés kapcsolatára fókuszálunk.

Az elemzés során a GeneZYs 2015-ös Kárpát-medencei ifjúságszociológiai felmérés Erdélyre vonatkozó adatait használtuk fel59, 15-29 éves magyar anyanyelvü fiatalokra reprezentatív (1000 erdélyi, 700 felvidéki, 500 vajdasági és 500 kárpátaljai), külhoni magyar fiatalok megkérdezésével készült kutatás. Elemzésünkhöz azért választottuk ezt az adatbázist, mert ez a felmérés részletesen vizsgálta a fiatalok szabadidős, illetve kulturális fogyasztását. A kulturális szegmentációt a különböző szabadidős tevékenységeken való részvétel gyakorisága alapján határoztuk meg. A megkérdezett fiatalok a kérdőívben felsorolt 27 esemény (lásd. Melléklet. 10.3.2.) látogatásának

\footnotetext{
${ }^{59}$ Mathias Corvinus Collegium (MCC), a Magyar Tudományos Akadémia Társadalomtudományi Kutatóközpont Kisebbségkutató Intézet (MTA TK KI) és az Információs Társadalomért Alapítvány INFOTA Kutatóintézetének együttmüködésében végzett felmérés.

A kutatás eredményeiről részletesebben lásd: Szerk. Papp Z. Attila „Változó kisebbség. Kárpátmedencei magyar fiatalok. A Genezys 2015 kutatás eredményei” Budapest. Mathias Corvinus Collegium - Tihanyi Alapítvány - MTA TK Kisebbségkutató Intézet. 2017
} 
gyakoriságát kellett bejelöljék egy 10 pontos skálán (1-soha, 10-nagyon gyakran). A fogyasztói csoportok meghatározásához a klaszterelemzés módszerét használtuk.

\subsection{Klaszterelemzés}

A szegmentáció céljára gyakran használt, többváltozós statisztikai módszer a klaszterelemzés, amely a megkérdezettek közötti struktúrák feltárásához, a fogyasztói rétegek szokásainak jobb megismeréséhez és feltérképezéséhez nyújt segítséget. Célja, hogy viszonylag heterogén objektumok ismérvei alapján viszonylag homogén csoportokat tárjon fel (Simon 2006; Sajtos-Mitev 2007).

A klaszterelemzés alkalmazása során az egyik eldöntendő kérdés, hogy melyik klaszterező algoritmust alkalmazzuk: a hierarchikus vagy nem hierarchikus módszert esetleg a kettő kombinációját. Több tényezőt kell figyelembe vennünk, amikor arról döntünk, hogy melyik klaszterező algoritmus lehet megfelelő egy kutatási kérdés megválaszolására. Az osztályozásról a szakirodalom hármas követelményt fogalmaz meg: (1) a sokaság minden egységének legyen helye valamelyik osztályban, (2) azok között lehetöleg ne legyen átfedés, illetve (3) hogy a megfigyelési egységeket viszonylag homogén csoportba rendezze (Simon 2006; Sajtos-Mitev 2007). Azt is mondhatnánk, hogy nincs egy univerzális klaszterező eljárás, a kutatási kérdéseknek megfelelően más és más algoritmussal, esetleg azok ötvözésével kaphatunk jó eredményt.

A hierarchikus módszerrel $n$ objektumot csoportosítunk, ahol a megjelenő csoportok száma ismeretlen, tehát meg kell találnunk az optimális csoportosítás számát. Az összevonáson (agglomeratív) és a felosztáson (divizív) alapuló eljárások közül választhatunk. Az összevonáson alapuló klaszterelemzésnél a folyamat megkezdésekor minden egyes elem külön klasztert alkot, az eljárás során aztán egyre nagyobb klasztereket vonunk össze (Sajtos-Mitev 2007). A klasztereket az adatpontok egymáshoz viszonyított távolságának megállapításával határozzuk meg, ugyanis egy adott pont sokkal inkább kötődik egy hozzá közel eső ponthoz, mint egy tőle távolabbihoz.

Az egyik leggyakrabban alkalmazott összevonó eljárás az általunk is használt Ward-módszer, melynek lényege olyan csoportosítás, amelyben a csoportokon belüli eltérés-négyzetösszeg minimális. A Ward távolság két klaszter átlagos elemével 
számol, a klaszterek egyedeinek számával súlyozva, és a szórásnégyzetet is figyelembe veszi (Mezei-Veres, 2001). A hierarchikus eljárások közös tulajdonsága, hogy az egyedeknek, illetve csoportjaiknak egy rendszerezett struktúráját, a pontok klaszterstruktúráját klaszterek egymásba ágyazott rendszereként adja meg.

A nemhierarchikus klaszter olyan módszer, amely az előre meghatározott csoportokat csoportosítja, így ebben a módszerben a klaszterek száma a kutatótól függően módosítható. Az egyik legnépszerübb klaszterező algoritmus a K-közép. Annak ellenére, hogy a K-átlagokat több mint 50 évvel ezelőtt javasolták, és azóta több ezer klaszterezési algoritmust publikáltak, a K-közép eljárást továbbra is széles körben használják. Népszerűségének fő okai a könnyű végrehajtás, az egyszerüség, a hatékonyság és az empirikus siker (Anil 2010).

A nemhierarchikus módszerek elöre megadott, $k$ számú klaszterből indulnak ki és az eljárás folyamán alakulnak ki a csoportok végleges létszámai. Ezek a módszerek különösen nagyméretü problémák vizsgálatára alkalmasak. A módszer alkalmazása akkor előnyős, ha a mintavételi egységek száma magas, és a kapott eredmények kevésbé függenek a kiugró adatoktól. Hátránya pedig az, hogy a klaszterek számát előre meg kell adni. Míg az elmúlt években a hierarchikus eljárások népszerübben voltak, föként a Ward, addig ma a nemhierarchikus eljárások elfogadottsága és elterjedtsége nő (Sajtos-Mitev 2007).

Egy másik fontos tényező a klaszterelemzés esetében a klaszterek számának meghatározása. Ez az egyik legfontosabb és legnehezebb tényező, ugyanis nincs egyértelmü mutató, amely minden esetben alkalmazható lenne. Az optimális klaszterszám meghatározásához többféle módszer, mutató alkalmazható: kutatói tapasztalat, elméleti megfontolások alapján (1), távolságok, dendogram alapján (2), klasztervaliditási indexek, könyökkritérium alapján (3) (Simon 2006; Szüle 2019).

Az elemzés során a lehetséges fogyasztói csoportok feltárására két eltérő módszert használtunk: a hierarchikus klaszterelemzést Ward módszerrel és a K-means módszert ${ }^{60}$. A továbbiakban a hierarchikus klaszterelemzés eredményeit mutatjuk be. A K-means módszerrel kapott eredményeket a 10.4.-10.5. számú Mellékletek tartalmazzák.

\footnotetext{
${ }^{60}$ Köszönettel tartozom Kmetty Zoltánnak, hogy felhívta a figyelmem a K-means klaszterelemzés hiányosságaira. Ennek eredményeként az elemzést elvégeztük a hierarchikus módszer segítségével is.
} 


\subsubsection{Hierarchikus klaszterelemzés. \\ Klaszterek meghatározása Ward módszerrel}

A kulturális fogyasztás és a társadalmi rétegződés közötti kapcsolat vizsgálatához, illetve a kutatási kérdésünk ellenőrzéséhez, azaz, hogy milyen tényezők befolyásolják a fiatalok kulturális fogyasztását, első lépésben megnéztük, hogy hány fogyasztói csoportot kapunk hierarchikus klaszterelemzéssel. A hierarchikus klaszterelemzést a Ward módszertan és euklideszi távolság alkalmazásával hajtottuk végre, melynek célja az optimális klaszterszámok meghatározása volt. Az eljárás kiválasztásában fontos szempont volt, hogy valamennyi változó metrikus skálán mért, nincsenek kiugró eseti értékek. Fontos cél volt a minél homogénebb csoportok képzése is. Az öszszevonó eljárások esetében az egyik elterjedt módszer a klaszterszámok meghatározására a „klaszterkönyök-mutatószám”, illetve a dendogram, amelyek szintén szemléletesen ábrázolják az eredményt. Feltételezéseink szerint a lehetséges klaszterszámok valahol 3 és 6 közöttire becsülhetők, az elméleti megfontolások alapján viszont az elvárt klaszterszám 4.

A klaszterkönyök-számításokat grafikusan ábrázoltuk (lásd 10.5. ábra) a koefficiens értékek alapján: a vízszintes tengely mutatja az összevonási lépések sorszámát, a függőleges tengely pedig a koefficiensek értékeit. A 10.6 ábra alapján a 914-es lépés után lenne célszerü meghúzni a határvonalat - ez három klasztert jelentene - viszont nem észlelhető egy határozott törés, valószínüsíthetően a nagy elemszám miatt.

\section{1. táblázat: Hierarchikus klaszterelemzés során az egyes klaszterek elemszáma}

\begin{tabular}{|c|c|c|c|c|c|c|c|c|}
\hline \multicolumn{3}{|c|}{ Hierarchikus klaszterelemzés - Ward módszer - Squared Euclidean distance } \\
\hline \multirow{2}{*}{ klaszterszám } & $\begin{array}{c}3 \text { klaszteres } \\
\text { megoldás }\end{array}$ & \multicolumn{2}{c|}{$\begin{array}{c}4 \text { klaszteres } \\
\text { megoldás }\end{array}$} & \multicolumn{2}{c|}{$\begin{array}{c}5 \text { klaszteres } \\
\text { megoldás }\end{array}$} & \multicolumn{2}{c|}{$\begin{array}{c}6 \text { klaszteres } \\
\text { megoldás }\end{array}$} \\
\cline { 2 - 9 } & $\mathrm{N}$ & $\%$ & $\mathrm{~N}$ & $\%$ & $\mathrm{~N}$ & $\%$ & $\mathrm{~N}$ & $\%$ \\
\hline 1 & 513 & 55.9 & 275 & 30.0 & 131 & 14.3 & 131 & 14.3 \\
\hline 2 & 168 & 18.3 & 168 & 18.3 & 168 & 18.3 & 168 & 18.3 \\
\hline 3 & 236 & 25.8 & 238 & 25.9 & 238 & 25.9 & 166 & 18.1 \\
\hline 4 & & & 236 & 25.8 & 144 & 15.7 & 72 & 7.8 \\
\hline 5 & & & & & 236 & 25.8 & 144 & 15.7 \\
\hline 6 & & & & & & & 236 & 25.8 \\
\hline $\mathrm{N}$ & 918 & 100 & 918 & 100 & 918 & 100 & 918 & 100 \\
\hline
\end{tabular}


A klaszterkönyök meghatározása kapcsán probléma lehet, hogy nagy adatbázisoknál az ábrán nem mindig rajzolódik ki a könyökalakzat (Szüle 2019), ahogy a mi ábránkon is észlelhető (lásd 10.5. ábra).

Ez azt jelenti, hogy a könyökmódszer alapján nem tudunk egyértelmü klaszterszámot meghatározni, ezért inkább a dendogramra (lásd. 10.6 ábra) hagyatkozunk a klaszterszámok meghatározásánál. A dendogram az elméletileg feltételezett klaszterszámokra vonatkozó elvárásokat erősíti meg, ami alapján a 4 klaszteres megoldás tünik a legstabilabbnak. Ennek alapján jól kirajzolódnak a klaszterszámok, bár így sem biztos, hogy határozott választ kapunk arra a kérdésre, hogy hány fogyasztói csoportot tudunk meghatározni a vizsgált adathalmazunk során. A struktúrafeltárás ezen eljárása csak exploratív célra alkalmas, a dendogram alapján hipotézis fogalmazható meg a mintabeli csoportok számára (Kovács 2014). Annak érdekében, hogy az optimális klaszterszámot meghatározzuk, a hierarchikus klaszterelemzést 6, 5, 4 és 3 klaszterre vonatkozóan is végrehajtottuk ${ }^{61}$.

Bármelyik eljárást alkalmazzuk, a 3-6 klaszteres megoldások mindegyikében körvonalazódik két határozott csoport, amelyek elemszáma egyik esetben sem módosul. A klaszterszám növelésével az első klaszter differenciálódik. A 3 klaszteres megoldás kevésbé tünik jó megoldásnak, mivel az első klaszter a megfigyelések 56\%-át tartalmazza, így ezzel a megoldással sok információt veszítünk. A 6 klaszteres megoldásnál az első klaszter esetében 14, a negyedik klaszter esetében a megfigyelések mindössze 7,8 százaléka tartozik, és a dendogram során sincs erre utaló információ. Az elemzés során a 4, illetve az 5 klaszteres megoldás került be a lehetséges változatok közé, majd föként az értelmezhetőség és az egyes klaszterekbe tartozó esetszámok alapján a négyklaszteres megoldást választottuk. Az 5 klaszteres megoldással azt tapasztalhatjuk, hogy a létrejött klaszterek interpretálása során nehézségekbe ütközünk. Azt látjuk, hogy többnyire ugyanazon szabadidős tevékenységek és hasonló gyakoriság jellemzi a két csoport fogyasztói profilját. Bár az egyik csoportban nagyobb gyakorisággal olvasnak könyvet és híreket, nagyobb arányban jellemző a színházlátogatás, illetve a sportolás, a másik csoportban viszont nagyobb arányban járnak könyvtárba. A hangversenyen való részvétel pedig hasonló arányú.

Mivel a dendogram alapján is 4 klaszter mutatkozik stabilnak, ugyanis megfelelően differenciálja a mintát, és jól indokolható csoportokat hoz létre, ugyanakkor elméletileg is ez a legmegalapozottabb, így ezt a fogyasztói struktúrát tartjuk meg.

\footnotetext{
${ }^{61}$ Lásd a „10. Mellékletek” részben a 10.21, 10.23, 10.25-ös táblázatokat.
} 


\subsubsection{Klaszterek leírása}

A klaszterek jellemzését a 8.2. táblázat alapján mutatjuk be, az egyes háttérváltozók közötti összefüggések vizsgálata kereszttábla-elemzéssel történt. Kifejezőbbnek véltük azokat a százalékokat megadni, hogy melyik csoporton belül nagyobb a nők, férfiak, idősebbek stb aránya. A táblázatban a százalékok az adott tevékenység gyakoriságát mutatják: itt a 100\%-ot a „nem-gyakorlás” - rejtett - változó adja meg. A fogyasztói csoportokat úgy próbáljuk meghatározni, hogy a másik három csoporthoz képest milyen tevékenységekben mutatnak magasabb vagy alacsonyabb gyakoriságot. Az első klasztert „,(magas)kultúra orientáltaknak”, a másodikat „mindenevőknek, a harmadikat „,sreenegereknek”, az utolsót pedig a „passzívaknak” neveztük el.

\section{2. táblázat: Kulturális aktivitások gyakorisága az egyes fogyasztói szegmensekben (\%)}

\begin{tabular}{|c|c|c|c|c|}
\hline & $\begin{array}{l}\text { (Magas)kultúra } \\
\text { orientáltak 30\% }\end{array}$ & $\begin{array}{c}\text { Mindenevök } \\
18,3 \%\end{array}$ & $\begin{array}{c}\text { Screenagerek } \\
25,9\end{array}$ & $\begin{array}{c}\text { Passzívak } \\
25,8\end{array}$ \\
\hline kirándulni a természetbe & 78.2 & 88.7 & 71.8 & 34.6 \\
\hline könyvtárba járni & 31.6 & 46.2 & 16.4 & 1.7 \\
\hline zenélni/festeni/rajzolni & 55.3 & 59.5 & 37.1 & 7.6 \\
\hline Facebookon/twitteren lógni, posztolni & 83.3 & 98.8 & 96.2 & 54.9 \\
\hline színházba járni & 39.6 & 73.8 & 22.3 & 3.4 \\
\hline hangversenyre, operába járni & 10.5 & 27.8 & 4.6 & 0.4 \\
\hline táncházba járni & 19.3 & 41.7 & 6.7 & 3.4 \\
\hline $\begin{array}{l}\text { filmeket nézni otthon (PC/Lap- } \\
\text { top/Tablet) }\end{array}$ & 85.1 & 92.9 & 95.0 & 52.3 \\
\hline írni (blogot, verset, prózát) & 17.1 & 28.4 & 10.1 & 1.3 \\
\hline könyvet olvasni & 60.0 & 82.7 & 37.8 & 8.9 \\
\hline sportolni, kocogni & 64.4 & 87.5 & 67.2 & 18.2 \\
\hline tévét nézni & 44.4 & 68.5 & 84.0 & 70.8 \\
\hline zenét hallgatni & 93.1 & 99.4 & 98.3 & 82.6 \\
\hline újságot, híreket olvasni & 60.1 & 83.3 & 49.6 & 16.9 \\
\hline híreket olvasni online & 72.0 & 90.5 & 57.4 & 14.4 \\
\hline online játékot használni & 30.1 & 35.7 & 44.3 & 12.3 \\
\hline barátokkal együtt lógni, beszélgetni & 87.6 & 98.2 & 97.5 & 66.1 \\
\hline kocsmába/sörözőbe/borozóba járni & 43.3 & 77.4 & 57.6 & 22.0 \\
\hline moziba járni & 27.6 & 58.3 & 22.8 & 3.0 \\
\hline klubokba, partykra járni & 30.2 & 85.1 & 57.6 & 5.5 \\
\hline szakkörön, képzéseken részt venni & 28.7 & 56.5 & 13.0 & 2.1 \\
\hline szoláriumba járni & 8.4 & 16.1 & 2.1 & 0.8 \\
\hline kozmetikushoz, fodrászhoz járni & 31.6 & 66.7 & 30.3 & 17.3 \\
\hline uszodába vagy szaunába járni & 27.6 & 46.2 & 10.1 & 1.7 \\
\hline fitness-szalonba, kondi-terembe járni & 31.3 & 36.7 & 10.5 & 1.3 \\
\hline chatelni & 59.8 & 92.9 & 89.9 & 25.0 \\
\hline plázába járni & 32.4 & 75.7 & 42.6 & 16.5 \\
\hline
\end{tabular}


A “(magas)kultúra-orientáltakat” a kulturális tevékenységben való aktív részvétel jellemzi. Azt látjuk, hogy ez a csoport a passzívakhoz képest mindenben jóval aktívabb, viszont a mindenevőkhöz képest minden tevékenységben alacsonyabb gyakoriságot mutat. A screenagerekhez hasonlítva erre a csoportra inkább jellemző a: színházlátogatás, hangverseny, opera, táncházak látogatása, zenélés, festés, rajzolás, írás (saját blog vagy vers). A könyvárba járás, illetve a könyvolvasás is hasonlóan magas gyakoriságot mutatnak. Tehát a szabadidős tevékenyégeikre jellemző a kulturális tevékenységekben való aktív részvétel, de nem olyan magas arányban, mint a mindenevők esetében, ezért neveztük őket „,(magas)kultúra orientáltaknak”. A megkérdezett fiatalok 30 százaléka alkotja.

A második csoportot a ,,mindenevök” csoportjának neveztük el, a fiatalok 18,3 százaléka tartozik ide. A fiatalok ezen részére az jellemző, hogy a vizsgált szabadidős aktivitások mindegyikében nagyon aktívak. Magas részvételt figyelhetünk meg mind a magaskulturális tevékenységekben, mind pedig a közösségi média használatában, ugyanakkor a kocsmába, sörözőbe, plázába járás is jellemző rájuk.

A harmadik klaszter a „,screenagerek” csoportja, a fiatalok 25,9 százaléka tartozik ide, akiknek az aktivitása nagyon szorosan kapcsolódik az internet, illetve a képernyők világához. Nagyon nagy arányban aktív Facebook-felhasználók. Jellemző rájuk, hogy otthon néznek filmeket a számítógépen, zenét hallgatnak és chatelnek, illetve elég gyakori tevékenységként jelenik meg az online játékok használata is. Az úgynevezett magas kultúrát megjelenítő tevékenységek, mint a színház, opera, hangverseny, könyvtár látogatása, illetve könyvolvasás jóval kevésbé jellemző erre a csoportra, mint a másik két klaszterbe tartozó fiatalokra.

A negyedik csoport a ,passzívak” (25,8\%) csoportja, akiknek mindenik szabadidős tevékenysége meglehetősen alacsony. Azok a fiatalok tartoznak ide, akiknek a fö tevékenységük elsősorban a zenehallgatás és tévénézés, illetve barátokkal való együtt lógás. Kis arányban jellemző még rájuk a Facebook-használat, illetve a laptopon való filmnézés. Minden más vizsgált tevékenység messze alulmarad a többi klasztereken belül folytatott gyakoriságától.

A 8.3. táblázat segítségével azt vizsgáltuk meg, hogy a kulturális aktivitások mentén kialakuló klasztereknek milyen társadalmi demográfiai jellemzői vannak. 


\section{3. táblázat: Társadalmi demográfiai csoportok kulturális klasztereken belüli aránya (\%)}

\begin{tabular}{|c|c|c|c|c|c|}
\hline & $\begin{array}{l}\text { (Magas)kultúra } \\
\text { orientáltak }\end{array}$ & Mindenevők & $\begin{array}{l}\text { Screenage- } \\
\text { rek }\end{array}$ & $\begin{array}{l}\text { Passzí- } \\
\text { vak }\end{array}$ & $\begin{array}{c}\text { Cramer's } \\
\mathrm{V}\end{array}$ \\
\hline $\mathrm{Nem}$ & & & & & 0.187 \\
\hline Nő & 48.7 & 64.5 & 36.1 & 49.8 & \\
\hline Férfi & 51.3 & 35.5 & 63.9 & 50.2 & \\
\hline Településtipus & & & & & 0.209 \\
\hline Falu & 41.5 & 42.6 & 50.0 & 67.4 & \\
\hline Város & 58.5 & 57.4 & 50.0 & 32.6 & \\
\hline Korcsoport & & & & & 0.180 \\
\hline 15-19 évesek & 21.1 & 38.1 & 38.1 & 19.5 & \\
\hline 20-24 évesek & 38.9 & 41.7 & 34.7 & 30.9 & \\
\hline 25-29 évesek & 40.0 & 20.2 & 27.2 & 49.6 & \\
\hline Iskolai végzettség & & & & & 0.221 \\
\hline Legfeljebb 8 osztály & 19.3 & 21.9 & 30.7 & 43.2 & \\
\hline Szakiskola & 4.0 & 5.9 & 14.3 & 20.8 & \\
\hline Érettségi (líceum, technikum) & 34.5 & 41.4 & 38.2 & 25.0 & \\
\hline BA, MA, PhD & 42.2 & 30.8 & 16.8 & 11.0 & \\
\hline Apa iskolai végzettség & & & & & 0.253 \\
\hline Legfeljebb 8 osztály & 5.6 & 3.3 & 7.7 & 37.1 & \\
\hline Szakiskola & 33.2 & 30.1 & 40.3 & 32.7 & \\
\hline Érettségi (líceum, technikum) & 37.2 & 48.4 & 39.8 & 25.2 & \\
\hline BA, MA, PhD & 24.0 & 18.3 & 12.2 & 5.0 & \\
\hline Foglalkozás & & & & & 0.272 \\
\hline $\begin{array}{l}\text { Beosztott, alkalmazott (nem } \\
\text { közszférában) }\end{array}$ & 26.8 & 19.9 & 26.9 & 23.0 & \\
\hline $\begin{array}{l}\text { Beosztott, alkalmazott közszfé- } \\
\text { rában }\end{array}$ & 18.4 & 7.2 & 7.7 & 11. & \\
\hline Vezető beosztású & 3.3 & 3.6 & 3.0 & 0.4 & \\
\hline Alkalmi munkából él meg & 2.9 & 2.4 & 4.3 & 10.9 & \\
\hline $\begin{array}{l}\text { Egyéni vállalkozó, társtulajdo- } \\
\text { nos }\end{array}$ & 4.0 & 0.0 & 1.7 & 3.5 & \\
\hline Tanuló, egyetemista & 33.5 & 60.8 & 42.3 & 13.5 & \\
\hline Inaktív, egyéb & 11.5 & 6 & 14.1 & 36.9 & \\
\hline Apa jelenlegi foglalkozása & & & & & 0.232 \\
\hline $\begin{array}{l}\text { Beosztott, alkalmazott (nem } \\
\text { közszférában) }\end{array}$ & 33.7 & 45.8 & 41.6 & 23.0 & \\
\hline $\begin{array}{l}\text { Beosztott, alkalmazott közszfé- } \\
\text { rában }\end{array}$ & 16.3 & 17.0 & 16.3 & 12.5 & \\
\hline Vezető beosztású & 7.9 & 10.5 & 6.3 & 3.0 & \\
\hline Alkalmi munkából él meg & 5.2 & 4.6 & 11.3 & 21.0 & \\
\hline $\begin{array}{l}\text { Egyéni vállalkozó, társtulajdo- } \\
\text { nos }\end{array}$ & 13.5 & 13.1 & 9.0 & 2.5 & \\
\hline Nyugdíjas & 15.1 & 4.6 & 6.8 & 16.0 & \\
\hline Inaktív, egyéb & 8.4 & 4.6 & 5.3 & 22.0 & \\
\hline \multicolumn{6}{|c|}{$\begin{array}{r}\text { Az összes bemutatott változó } 0.000 \text { szinten szignifikáns kapcsolatot jelez, } \\
\text { ezért nem jelöltük külön a táblázatban. }\end{array}$} \\
\hline
\end{tabular}


A 8.3. táblázat alapján a ,screenagerek” inkább férfiak, korcsoport szerint a 1519 éves, és főleg érettségivel rendelkező fiatalok. A szülők családi hátterére vonatkozóan az apa iskolai végzettségét és foglalkozását néztük meg, mely szerint az apák főleg szakiskolával és érettségivel rendelkeznek, foglalkozási pozíciójukat tekintve pedig föleg alkalmazottak.

A ,(magas)kultúra orientáltak” szintén férfiak; városban élő 25-29 éves fiatalok. Iskolai végzettségük szerint föleg egyetemi diplomával vagy érettségivel rendelkeznek. A szülői háttérről az mondható el, hogy többnyire egyetemi vagy magiszteri diplomával rendelkező szülök gyerekei tartoznak ebbe a csoportba.

A „mindenevő” csoport tagjai inkább nők, városi származásúak, és a fiatalabb korcsoportból kerülnek ki, azaz 15-19 évesek. Az apa jelenlegi foglalkozásának elemzése alapján pedig föleg alkalmazottak, de ebbe a csoportba kerül a legtöbb vezető beosztású, illetve vállalkozó szülő gyereke is. Iskolai végzetségüket tekintve, mivel egy fiatalabb korosztály van ebben a csoportban, főleg érettségi diplomával rendelkezők, feltételezhetően jelenleg is tanuló fiatalok.

A negyedik klaszterbe a ,passzívak”, azaz inkább azt mondhatnánk, hogy a különböző kulturális tevékenységeket nélkülöző fiatalok tartoznak, akik társadalmi-demográfiai jellemzők alapján inkább férfiak (de nem számottevő a különbség a férfiak és nők között), föleg falusi környezetben élők, életkor szerint pedig idősebbek, 25-29 évesek. Iskolai végzettség szerint a legfeljebb 8 osztályt vagy szakiskolát végzettek vannak felülreprezentálva, ami hasonló eloszlást mutat az apa iskolai végzettsége esetében is. Foglalkozás szerint pedig inkább alkalmi munkából élők vagy inaktívak.

A fentiek alapján azt állíthatjuk, hogy a negyedik csoport tagjai tipikusan alacsony társadalmi státusúak, míg az első és második csoport tagjai inkább magasabb társadalmi státusú csoportokból kerülnek ki. Azt láthattuk, hogy a magyarázó változók közül az apa iskolai végzettsége (Cramer`s V: 0.25; Sig<0.00) illetve foglalkozása (Cramer`s V: 0.23; Sig<0.00) erös összefüggést mutat a klaszterekkel, de ugyanakkor a településtípus (Cramer`s V: 0.29; Sig<0.00), a nem (Cramer`s V: 0.18; Sig<0.00) és az életkor (Cramer`s V: 0.18; Sig<0.00) is jelentős hatást gyakorol a csoporthovatartozásra. 
Az előzőekben már jeleztük, hogy a fogyasztói csoportokat két klaszterező eljárással is elvégeztük, az eddigi szakirodalmi (Sági 2010; Fekete-Prazsák 2014; Croitoru-Becuț 2017) tapasztalatok alapján egyszer K-means (lásd. melléklet) klaszterelemzéssel csoportosítottuk a fiatalokat különböző fogyasztói csoportokba. Ennek validitását a hierarchikus, Ward módszer eljárás segítségével ellenőriztük. A K-

means klaszterelemzéssel létrehozott csoportokat összehasonlítva a Ward módszerrel kapott csoportokkal azt látjuk, hogy ez utóbbi esetében a településtípus és a csoporthovatartozás között erősebb a kapcsolat (Cramer`s V: 0.29; Sig<0.00 illetve Cramer`s V: 0.17; Sig<0.00). Bár valószínüsíthetően ez a „screenegerek” csoportjára nem érvényes, ugyanis azt látjuk, hogy ugyanolyan arányban vannak falusi és városi fiatalok ebben a csoportban. Egy másik különbség, amit a két különböző csoportosítás eredményezett, hogy a Ward módszerrel a „,(magas)kultúra orientáltak” csoportjába bár nem számottevően, de inkább kerültek férfiak (51,3\%), mint nők (48,7\%), míg a Kmeans elemzés fordított eloszlást eredményezett. (55\% nő és $45 \%$ férfi). A két módszer nem mutat számottevő különbséget a csoportok összetételében, ezért a K-means klaszterelemzés részletes eredményeit csupán a mellékletben mutatjuk be.

\subsection{Kulturális szegmentációt befolyásoló tényezők. Regresszió-elemzések}

\subsubsection{Logisztikus regresszióelemzés}

A társadalmi-demográfiai jellemzők bemutatását követően logisztikus regreszszió módszerével vizsgáljuk meg, hogy milyen tényezők befolyásolják az egyes csoportokba való bekerülést. Elemzésünk arra keresi a választ, hogy a felvázolt három elmélet közül melyik megközelítés ad magyarázatot az erdélyi magyar fiatalok kulturális fogyasztásának szegmentációjára.

A regressziós modellekben a klasztertagság a függő változó, és a klasszikus státusváltozók (foglalkozás, iskolai végzettség) valamint a szocio-demográfiai tényezők (nem, életkor, településtípus) pedig a független változók. Az elemzésnek két kimenetele lehet: ha nincs kapcsolat a klasztertagság és a független változók között, akkor 
valóban igaz az, hogy a fogyasztás szerinti szegmentációnak nincs köze a klasszikus réteghelyzethez (a homológia tézis teljesen megdőlt). Vagy van összefüggés, ami azt jelenti, hogy mégsem teljesen individualizáltak az egyenlőtlenségek, tehát a horizontális fogyasztói tagolódás nem váltotta fel a vertikálisat.

Először a logisztikus regresszió módszerével vizsgáltuk a magyarázó változók kulturális fogyasztásra gyakorolt hatását. Minden egyes csoportba való tartozás magyarázatára egy külön regressziós modellt futtattunk le. A modellek függő változói: screenagerek, (magas)kultúra orientáltak, mindenevők, passzívak, referenciaértékeit pedig az adott csoportba nem tartozó összes többi személy jelenti.

Mivel a 15-29 év közötti fiatalok körében még sokan nem fejezték be az iskolát, illetve nem léptek be a munkaerőpiacra, relevánsabbnak tartottuk a családi háttértényezőkkel vizsgálni a kutatási kérdéseinket. Független változóknak ezért az apa iskolai végzettségét és foglalkozását választottuk, illetve a megkérdezett életkorát és nemét. A településtípust is bevontuk, elemzésünkben ugyanis, amikor a klaszterek társadalmi demográfiai jellemzőit vizsgáltuk, a településtípus között is szignifikáns kapcsolatot mutattunk ki.

A logisztikus regressziós modellek értékeit a 8.4. táblázat foglalja össze, melynek együtthatói úgy értelmezhetők, hogy a referencia kategóriához képest, amelyet a táblázat alján tüntettünk fel, hányszor nagyobb az esélye egy fiatalnak arra, hogy inkább a függő változó által jellemzett csoportba tartozzon, mint hogy abból kimaradjon. 
8.4. táblázat: Az egyes kulturális csoportokba való tartozást befolyásoló tényezők. Logisztikus regressziós modellek együtthatóinak exponenciális értékei Exp (b)

\begin{tabular}{|l|c|c|c|c|}
\hline \multicolumn{1}{|c|}{ Magyarázó változók } & $\begin{array}{c}\text { (Magas)kul- } \\
\text { túra } \\
\text { orientáltak }\end{array}$ & $\begin{array}{c}\text { Minden- } \\
\text { evők }\end{array}$ & $\begin{array}{c}\text { Screenage- } \\
\text { rek }\end{array}$ & Passzívak \\
\hline Apa iskolai végzettség & & & & \\
\hline Legfeljebb 8 osztály & .112 & .276 & .802 & 14.763 \\
& $(.000)$ & $(.035)$ & $(.581)$ & $(.000)$ \\
\hline Szakiskola & .487 & .794 & 1.889 & 2.381 \\
& $(.004)$ & $(.450)$ & $(.029)$ & $(.035)$ \\
\hline Érettségi (líceum, technikum) & .474 & 1.186 & 1.709 & 1.858 \\
& $(.002)$ & $(.555)$ & $(.059)$ & $(.134)$ \\
\hline Apa jelenlegi foglalkozása & & & & \\
\hline Beosztott, alkalmazott (nem közszférá- & .601 & 2.802 & 1.464 & .573 \\
ban) & $(.031)$ & $(.002)$ & $(.142)$ & $(.036)$ \\
\hline Beosztott, alkalmazott közszférában & .708 & 1.821 & 1.528 & .730 \\
& $(.215)$ & $(.127)$ & $(.157)$ & $(.316)$ \\
\hline Vezetö beosztású, egyéni vállalkozó, & .801 & 3.189 & 1.162 & .368 \\
társtulajdonos & $(.420)$ & $(.002)$ & $(.632)$ & $(.010)$ \\
\hline Alkalmi munkából él meg & .490 & 1.308 & 1.339 & 1.267 \\
& $(.048)$ & $(.593)$ & $(.384)$ & $(.459)$ \\
\hline Korcsoport & & & & \\
\hline 15-19 évesek & .531 & 2.196 & 2.059 & .444 \\
& $(.004)$ & $(.004)$ & $(.001)$ & $(.001)$ \\
\hline 20-24 évesek & .932 & 1.942 & 1.252 & .501 \\
& $(.719)$ & $(.011)$ & $(.301)$ & $(.003)$ \\
\hline Neme & & & & \\
\hline Férfi & 1.176 & .354 & 2.149 & .809 \\
& $(.328)$ & $(.000)$ & $(.000)$ & $(.286)$ \\
\hline Településtípus & & & & \\
\hline Falu & .764 & .853 & 1.068 & 1.582 \\
& $(.117)$ & $(.441)$ & $(.713)$ & $(.027)$ \\
\hline Konstans & .1 .655 & .120 & 0.087 & .210 \\
\hline Nagelkerke R négyzet & .118 & .092 & .294 \\
\hline
\end{tabular}

Referenciakategóriák: felsőfokú végzettség, nyugdíjas- inaktív, 25-29 éves, nő, város

A zárójelben szereplő számok a p értékek.

A logisztikus regresszió együtthatói azt mutatják, hogy az apa foglalkozása jelentős mértékben befolyásolja a mindenevők csoportjába való tartozást, vagyis azoknak a fiataloknak, akiknek az apja beosztott alkalmazott (nem közszférában), illetve vezető, háromszor nagyobb az esélyük arra, hogy a mindenevők csoportjába tartozzanak, szemben azokkal, akiknek az apja inaktív. Az apa iskolai végzettsége az alacsony iskolai végzettség esetében szignifikáns, ami azt jelenti, hogy kisebb eséllyel tartoznak alacsony végzettségüek gyerekei a mindenevők csoportjába. Nemek tekintetében a mindenevők csoportjába inkább tartoznak nők, mint férfiak. Előzetes feltételezéseink szerint a mindenevők csoportjának erőteljes életkori meghatározottsága is van. A 
25-29 évesekhez képest kétszer nagyobb valószínüséggel tartoznak 15-19 évesek ebbe a csoportba, és közel kétszer nagyobb valószínűséggel a 20-24 évesek. Az eredményeink megegyeznek a magyarországi felmérés eredményeivel (Sági 2010), miszerint a mindenevő csoportnak erőteljes életkori meghatározottsága van, ugyanakkor a mindenevők csoportjába való tartozást jelentős mértékben befolyásolja az apa foglalkozási pozíciója.

A (magas)kultúra orientáltak csoportjába való tartozást elsősorban az apa iskolázottsága határozza meg, vagyis nagyobb eséllyel tartoznak azok a fiatalok ebbe a csoportba, akiknek az apja magasabb iskolai végzettséggel rendelkezik. Ugyanakkor számít a kor és az apa foglalkozása is - minél prekáriusabb (alkalmi munkából él meg), annál kevésbé jellemző, hogy a gyereke magaskultúrát fogyaszt - még úgy is, ha kontroll alatt tartjuk az iskolai végzettséget. A foglalkozási státusnak a végzettségtöl függetlenül is van hatása.

A screenagerek csoportját inkább demográfiai jellegzetességek mentén lehet leírni. Kétszer nagyobb eséllyel tartoznak férfiak és 15-19 évesek ebbe a csoportba, ugyanakkor az apa iskolai végzettségét tekintve is találtunk szignifikáns összefüggéseket. A felsőfokú végzettekhez viszonyítva a szakiskolával rendelkező szülők gyerekeinek kétszer akkora esélye van arra, hogy a screenagerek csoportjában tartozzon, mint egy másik csoportba.

Végül a passzívak csoportját elemezve szignifikáns kapcsolatot mutathatunk ki az apa iskolai végzettsége és a csoportba kerülés között: minél alacsonyabb az apa iskolai végzettsége, annál nagyobb az esélye a fiatalnak, hogy ebbe a csoportba kerüljön. Ezt a klasztert alacsonyabb iskolai végzettség, illetve az idősebb életkor jellemzi. Az idősebb korosztály kulturális fogyasztásban való inaktivitását egy rejtett változó is magyarázhatja: a gyerekvállalás vagy a munkába állás miatt is csökkenhet a kulturális aktivitás. Ebben az esetben a településtípus is szignifikáns kapcsolatot mutat, közel kétszer akkora eséllyel vannak falusi fiatalok ebben a csoportban, mint városiak.

A mellékletben bemutatott K-means klaszterelemzéssel kialakított csoportok esetében hasonló eredményeket kaptunk, kivéve a településtípus változót, ami nem mutatott szignifikáns kapcsolatot egyik csoport esetében sem. 


\subsubsection{Multinomiális regresszióelemzés}

Az előbb alkalmazott binomiális logisztikus regresszió ${ }^{62}$ minden egyes klaszternél a másik háromhoz viszonyítja az adott klaszterhez tartozást. Ennél jobb módszer a multinomiális logisztikus regresszió, amivel páronként hasonlíthatjuk össze a klasztereket.

Tudva azt, hogy a mi függő változónk (klaszterek) alapvetően nem dichotóm változók, az elemzést tovább finomítottuk, és a multinomiális logisztikus regresszió módszerével is megvizsgáltuk a kulturális tevékenységeket befolyásoló tényezőket. A multinomiális regressziót úgy foghatjuk fel, mint szimultán módon meghatározott dichotóm függő változós logisztikus regressziós egyenletek sorozatát (Moksony 2006), ahol a függő változót hasonlítja össze azzal a kategóriával, amit kihagytunk az elemzésből, vagyis a referencia kategóriával. Tehát ebben az esetben a klasztereket együttesen vizsgáljuk, a „passzívak” klasztert referencia kategóriaként kijelölve. A magyarázó változók hasonlóak: apa iskolai végzettsége, apa jelenlegi foglalkozása, életkor, nem és településtípus.

A multinominális logisztikus regressziós modell értékeit a 8.5. táblázat tartalmazza. Az együtthatók azt mutatják meg, hogy hogyan befolyásolja a magyarázó változó annak esélyét, hogy valaki a referenciakategóriához képest inkább melyik csoportba tartozik.

${ }^{62}$ Ezt a módszert alapvetően akkor alkalmazzuk, ha a függő változónk dichotóm. 
8.5. táblázat: Az egyes kulturális csoportokba való tartozást befolyásoló tényezök. Multinominális regressziós modellek együtthatóinak exponenciális értékei Exp (b)

\begin{tabular}{|c|c|c|c|}
\hline Magyarázó változók & $\begin{array}{l}\text { (Magas)kultúra } \\
\text { orientáltak }\end{array}$ & Mindenevők & Screenagerek \\
\hline \multicolumn{4}{|l|}{ Apa iskolai végzettség } \\
\hline Legfeljebb 8 osztály & $\begin{array}{c}.038 \\
(.000)\end{array}$ & $\begin{array}{c}.054 \\
(.000) \\
\end{array}$ & $\begin{array}{c}.152 \\
(.000)\end{array}$ \\
\hline Szakiskola & $\begin{array}{c}.306 \\
(.006) \\
\end{array}$ & $\begin{array}{c}.383 \\
(.044) \\
\end{array}$ & $\begin{array}{c}.744 \\
(.526) \\
\end{array}$ \\
\hline Érettségi (líceum, technikum) & $\begin{array}{r}.369 \\
(.021) \\
\end{array}$ & $\begin{array}{c}.651 \\
(.362) \\
\end{array}$ & $\begin{array}{c}.860 \\
(.746) \\
\end{array}$ \\
\hline \multicolumn{4}{|l|}{ Apa jelenlegi foglalkozása } \\
\hline Beosztott, alkalmazott (nem közszférában) & $\begin{array}{l}1.107 \\
(.737) \\
\end{array}$ & $\begin{array}{l}3.654 \\
(.001) \\
\end{array}$ & $\begin{array}{l}2.055 \\
(.024) \\
\end{array}$ \\
\hline Beosztott, alkalmazott közszférában & $\begin{array}{l}1.002 \\
(.996) \\
\end{array}$ & $\begin{array}{l}2.101 \\
(.107) \\
\end{array}$ & $\begin{array}{l}1.715 \\
(.148) \\
\end{array}$ \\
\hline Vezető beosztású, egyéni vállalkozó, társtulajdonos & $\begin{array}{l}2.006 \\
(.099)\end{array}$ & $\begin{array}{l}6.014 \\
(.000)\end{array}$ & $\begin{array}{l}2.625 \\
(.033)\end{array}$ \\
\hline Alkalmi munkából él meg & $\begin{array}{c}.505 \\
(.095) \\
\end{array}$ & $\begin{array}{l}1.079 \\
(.888) \\
\end{array}$ & $\begin{array}{l}1.071 \\
(.858) \\
\end{array}$ \\
\hline \multicolumn{4}{|l|}{ Korcsoport } \\
\hline 15-19 évesek & $\begin{array}{l}1.217 \\
(.508)\end{array}$ & $\begin{array}{l}3.547 \\
(.000)\end{array}$ & $\begin{array}{l}3.047 \\
(.000)\end{array}$ \\
\hline 20-24 évesek & $\begin{array}{l}1.676 \\
(.050) \\
\end{array}$ & $\begin{array}{l}3.036 \\
(.001) \\
\end{array}$ & $\begin{array}{l}2.008 \\
(.012) \\
\end{array}$ \\
\hline \multicolumn{4}{|l|}{ Neme } \\
\hline Férfi & $\begin{array}{l}1.248 \\
(.325)\end{array}$ & $\begin{array}{l}0.499 \\
(.008)\end{array}$ & $\begin{array}{l}1.933 \\
(.004)\end{array}$ \\
\hline \multicolumn{4}{|l|}{ Településtipus } \\
\hline Falu & $\begin{array}{l}.574 \\
(.018)\end{array}$ & $\begin{array}{l}.601 \\
(.056)\end{array}$ & $\begin{array}{c}.724 \\
(.177)\end{array}$ \\
\hline Nagelkerke R négyzet & 0.314 & 0.314 & 0.314 \\
\hline
\end{tabular}

Referenciakategóriák: felsőfokú végzettség (BA, MA, PhD), nyugdíjas, inaktív vagy egyéb, 25-29 éves, nő, város, 4-es klaszter (Passzívak)

Az életkori sajátosságok ebben az esetben is erőteljesen befolyásolják a csoporthovatartozást. A multinominális regressziós modell értelmezése szerint az életkornak van a legnagyobb hatása a csoporthovatartozás tekintetében. A fiataloknak (15-19 éveseknek) az idősebbekhez (25-29 évesekhez) képest háromszoros az esélye arra, hogy a 4. klaszter (passzívak) helyett a screenagerek csoportjába tartozzanak, és három és félszer nagyobb az esélyük, hogy a mindenevők csoportjába tartozzanak, mindezt úgy, hogy a többi tényező hatását, mint az apa iskolai végzettségét és foglalkozását, is figyelembe vettük.

Az apa iskolai végzettsége is szignifikáns összefüggést mutat a csoporthovatartozással: minél magasabb az apa iskolai végzettsége, annál nagyobb az esélye annak, 
hogy a megkérdezett a (magas)kultúra orientáltak, illetve a mindenevők csoportjába tartozzon. Az eredményeink részben alátámasztják az individualizációs hipotézist, mely szerint a mai modern fogyasztói társadalomban kialakuló társadalmi csoportokat (miliőket) inkább az életkor és a képzettség (Schulze 2000) határozza meg.

Az apa foglakozása a mindenevők esetében mutat szignifikáns kapcsolatot, mely szerint, ha az apa vezető pozíciót tölt be, a megkérdezett annál nagyobb valószínűséggel tartozik a mindenevők csoportjába. Azon megkérdezetteknek, akiknek az apja vezető beosztású vagy egyéni vállalkozó, hatszoros az esélye arra, hogy a 4. (passzívak) klaszter helyett a mindenevők csoportjába tartozzon, illetve akiknek az apja beosztott, de nem közszférában, az közel négyszeres eséllyel kerül inkább a mindenevő klaszterbe.

\section{4. Összefoglalás}

Jelen fejezetben az erdélyi magyar fiatalok kulturális szegmentációját mutattuk be a különböző kulturális eseményeken (magas, illetve populáris kulturális események) való részvétel alapján. Célunk az volt, hogy több módszer alkalmazásával megvizsgáljuk a társadalmi rétegződés szakirodalmában megjelenő „omnivore-univore” elmélet érvényességét az erdélyi magyar fiatalok körében, mely szerint a „kulturális mindenevőség” felbukkanása fellazítja az osztályalapú megkülönböztetést a kulturális fogyasztás tekintetében.

Eredményeink szerint az erdélyi magyar fiatalok körében is markánsan kirajzolódik egy új fogyasztói csoport: a mindenevők csoportja, akik szocio-demográfiai szempontból határozottan elkülönülnek a másik három csoporttól, a (magas)kultúra orientáltaktól, screenagerektől és passzívaktól. A mindenevők csoportjába leginkább nők, városi származásúak és a fiatalabb korosztály tartozik. Az apa foglalkozása szerint, a legtöbb vezető beosztású, illetve vállalkozó szülő gyereke van ebben a csoportban. A „screenagerek” inkább férfiak, korcsoport szerint szintén fiatalabbak, 15-19 évesek, és föleg érettségivel rendelkező fiatalok. A szülők családi hátterére vonatkozóan az apák főleg szakiskolával és érettségivel rendelkeznek, foglalkozási 
pozíciójukat tekintve pedig alkalmazottak. A „(magas)kultúra orientáltak” csoportjára jellemző, hogy városban élő 25-29 éves fiatalok, többségében férfiak. Iskolai végzettségük szerint főleg egyetemi diplomával vagy érettségivel rendelkeznek, és többnyire egyetemi vagy magiszteri diplomával rendelkező szülők gyerekei. A passzívak körében szintén inkább férfiak vannak, föleg falusi környezetben élők, életkor szerint pedig idősebbek, 25-29 évesek. Iskolai végzettség szerint a legfeljebb 8 osztályt vagy szakiskolát végzettek vannak felülreprezentálva. Alacsonyabb iskolai végzettségü szülők gyerekei, foglalkozás szerint pedig inkább alkalmi munkából élők vagy inaktívak.

Mindkét módszer, a logisztikus és a multinomiális regresszió is ahhoz a következtetéshez vezet, hogy a mindenevők csoportjába tartozást leginkább a foglalkozási pozíció és az életkor határozza meg, de ugyanakkor az iskolázottság is befolyásoló tényező. Ez megegyezik Chan és Goldthorpe (2007, 2010) megállapításaival, mely szerint az exkluzív (magas)kultúrafogyasztók mellett jól láthatóan megjelennek a „mindenevők”, akik magas státusú, felsőfokú végzetséggel rendelkező fiatalok.

Továbbá azt láthattuk, hogy a vizsgált tényezők - apa foglalkozása, iskolai végzettsége, nem, életkor, településtípus - mindenike hatással van a csoporthovatartozásba. A „mindenevők” csoportjában főleg az apa foglalkozása, a (magas)kultúra orientáltak csoportjában az apa iskolai végzettsége, a „screenegerek” esetében a nem és az életkor az elsődleges szegmentáló tényezők, a passzívak csoportjában pedig szintén az apa iskolai végzettsége és az életkor.

Az empirikus elemzések legfőbb tanulsága, hogy a „passzívak” referenciakategóriához képest egy magas iskolai végzettséggel rendelkező apa gyermeke nagyobb eséllyel screenager, nagyobb eséllyel vesz részt kulturális tevékenységekben, és még nagyobb eséllyel lesz mindenevő, továbbá egy vezető beosztású apa gyermekének a legnagyobb az esélye arra, hogy a mindenevők csoportjába tartozzon. A fiatalok kulturális szegmentációját mind az apa iskolai végzettsége, mind pedig a jelenlegi foglalkozása befolyásolja, ugyanakkor az életkor is fontos tényező a csoporthovatartozás tekintetében.

Azt gondoljuk, hogy „omnivore-univore” elmélet egy köztes perspektívát ad a tradicionális kulturális hierarchikus megközelítés és a radikális posztmodern 
megközelítés helyett, elutasítja a hagyományos értelemben vett kulturális fogyasztás hierarchikus voltát, és azt mondja, hogy a fogyasztás szokásvilágában egy olyan elmozdulásnak lehetünk tanúi, ami nem egy elit-tömegkultúra tengely mentén képzelhető el, hanem inkább egy „omnivore-univore” tengelyen (Bukodi 2010; Sági 2010). A kulturális mindent fogyasztás jelensége, a „mindenevők” csoportja markánsan elkülönül a többi kulturális fogyasztási szegmenstől, viszont az „univore” típus keleteurópai kontextusban sokkal inkább a „passzívak” csoportjával jellemezhető. Tehát a magyar társadalomhoz hasonlóan az erdélyi magyar fiatalok esetében is a kulturális magatartásformák lényegi választóvonala nem az „omnivore-univore” tengely mentén helyezkedik el, hanem sokkal inkább egy „,mindenevő-nélkülöző” tengelyen. (Bukodi 2010; Sági 2010) 


\section{9. Összegzés}

A társadalomkutatás a Kelet-Európai rendszerváltást követő társadalom-szerkezeti változásokat több irányból közelítette meg és igyekezett azonosítani a rétegződést befolyásoló dimenziókat, illetve azok - hirtelen - változásait. Mind a nemzetközi, mind a magyarországi társadalomtudományi kutatás esetében nagy hangsúlyt fektettek a társadalmi rétegződés- és struktúrakutatás módszertanának a megalapozására. A társadalom szerkezetének - a státus, a rétegződés, illetve a strukturális viszonyok leírásának - ennek ellenére sincs egy egységes, általánosan elfogadott elmélete, sem módszertana, ezért ki-ki maga dönti el, a vizsgált társadalmi közeg függvényében, hogy milyen elméleti modellből indul ki és milyen eszköztárat használ.

A második fejezetben mutattuk be a rétegződéskutatások új struktúra-megközelítéseit, miszerint a társadalomszerkezet leírásában a fogyasztási-, illetve életstíluscsoportok a meghatározóak (Pakulski-Waters 1996; Beck 2004). Ezek a hagyományos, a munkaerő-piaci pozíción, illetve a foglalkozáson alapuló osztály- és rétegződési modellekkel (Bourdieu 1978b; Erikson-Goldthorpe-Portocarero 1988) szemben helyezkednek el. A szociológia szakirodalmában egyre nagyobb figyelmet kap az „omnivore”, a „mindenevőség” fogalma, ami a homológia és az individualizáció elméleteket egészíti ki. E három fő elméleti megközelítés mentén vizsgáltuk az erdélyi magyar fiatalok rétegződését, kitérve a foglalkozásszerkezeti megközelítésekre is. Célunk nem a korábbi elméletek validitásának felülvizsgálata volt, hanem a nemzetközi szakirodalomban megjelent új irányok mentén - a fogyasztási paramétereket is figyelembe véve - megvizsgáljuk az erdélyi magyar fiatalok körében a főbb struktúraképző elemeket.

A harmadik fejezetben, az „3. Ifjúságelméleti megközelítések” rész alapján a különböző kutatócsoportok módszertani kereteinek a heterogenitására hívjuk fel a figyelmet: azt láthattuk, hogy mind a magyarországi, mind a román, mind pedig az erdélyi magyar elemzések nagyon eltérő szempontok szerint csoportosították a fiatalokat. Dolgozatunk módszertanához legközelebbi elemzést Magyarországon (FeketePrazsák 2014) és (Bokányi-Gyorgyovich-Pillók 2018) végeztek. Fekete és Prazsák 
elemzése - a fiatalok kulturális rétegződését vizsgálva - négy kultúrafogyasztói csoportot azonosítottak: a kulturálisan szegény, a könnyed szórakozó, az „omnivore”, és az elit (Fekete-Prazsák 2014). A második elemzés a „Magyar Ifjúság Kutatás 2016” a magyarországi fiatalok hat klaszterét azonosította, ezek a magányosak, a közélet iránt közömbös társaságiak, a társasági müveltek, a jólétben élő optimista aktívak, az anyagilag deprivált optimisták, valamint pesszimisták. (Bokányi-Gyorgyovich-Pillók 2018). A mi dolgozatunk eredményei a Fekete és Prazsák elemzésével korrelálnak leginkább, három csoport esetében szoros megegyezés figyelhető meg; a negyedik csoport nálunk a screenager nevet viseli, amíg Fekete-Prazsák könnyed szórakozónak hívják ezt a csoportot. A különbség valószínűsíthetően a használt változók mássága miatt van. Egy másik lehetséges magyarázat a névbeli különbségre a 2012 és 2016 között tapasztalt exponenciális fejlődés a technológiai és a közösségi hálók terén.

Az erdélyi magyar fiatalok körében végzett csoportosításokban is nagy szórás figyelhető meg. Veres a fiatalok kulturális fogyasztási mintázatait elemezve - faktoranalízis módszerével - a román fiatalok körében négy fogyasztói csoportot alakított ki: a screenagerek, klubkultúra fogyasztók, magaskultúra fogyasztók és otthoni irodalomolvasók csoportja (Veres 2017b). Az erdélyi magyar fiatalok körében pedig három csoportot nevez meg: screenagerek, a magaskultúra-fogyasztók, klubkultúra fogyasztók (Veres 2011). A magyar minta esetén az „otthoni irodalomolvasók” és a „magaskultúra fogyasztók" csoportja nem vált külön. Barna, ugyanolyan módszerrel és ugyanazokat az adatokat elemezve, mind a román mind pedig a magyar fiatalok körében négy csoportot különböztet meg: szórakozásorientált, kultúraorientált, a mozgásorientált és a médiaorientált csoportokat (Barna 2011).

A fentebbi kutatások eltérő csoportosításai aláhúzzák a már (Lambert 2019) által említett megállapítást, miszerint az elméleti következtetésekben megmutatkozó különbségek nagymértékben az eltérő módszertani stratégiáikból fakadnak. Éppen azért fontosnak tartottuk, hogy kutatási kérdéseinket több módszerrel is validáljuk. (a K.mens klaszterelemzési eljárást a hierarchikus klaszterező módszerrel ellenőriztük) 


\subsection{Kutatási kérdések és eredmények}

A dolgozat első részében az ifjúság főbb jellemzőit mutattuk be, három hagyományos rétegződési dimenzió szerint - iskolai végzettség, szubjektív jövedelem, foglalkozási szerkezet (6. fejezet). A fiatalok iskolai végzettségét vizsgálva kimutatható, hogy a felsőoktatásban részt vevők aránya növekedett, egyre több fiatalnak van magasabb iskolai végzettsége a szülei (apa) iskolai státusánál. Az apa iskolai végzettségének továbbra is fontos szerepe van a fiatalok továbbtanulásában. Az anyagi helyzetet vizsgálva megállapítottuk, hogy az erdélyi magyar fiatalok jóléte is jelentősen emelkedett, viszont ez nem egyértelmüen az egyenlőtlenségek csökkenését jelenti, inkább egy általános életszínvonalbeli javulásról van szó.

A foglalkozási rétegszerkezet a fiatalok esetében vertikálisan differenciálódik: minél magasabb az apa iskolai végzettsége, annál valószínübb, hogy a megkérdezett fiatal vállalkozó vezető vagy értelmiségi foglalkozású, illetve az általános/szakiskolai végzettségü szülők gyerekei inkább szakmunkások.

Ugyanakkor azt is meg kell említenünk, hogy az elmúlt évtizedekben megváltozottmunkaviszonyok (Csata et al. 2009), a rugalmas foglalkoztatási formák elterjedése megnehezíttették a foglalkozási rétegszerkezetek vizsgálatát. Továbbá a fiatalok egyre hosszabb ideig tanulnak (Zinnecker 1993), kevesen rendelkeznek stabil jövedelemmel, munkaerőpiaci státussal, így a foglalkozási besorolás alapján nem, vagy csak kevés sikerrel lehet a fiatalok társadalmi szerkezetét megismerni. Úgy gondoljuk, hogy az ezredforduló utáni társadalmi változás dinamikája és iránya a fiatalok esetében nem érthető meg csupán a hagyományos osztályszerkezeti modellekből kiindulva. Crompton állításával egyetértve azt mondhatjuk, hogy a foglalkoztatási megközelítések alkalmazásával nem lehet minden osztályalapú problémát feltárni (CromptonScott 2014). Ez a fiatalok esetében különösen érvényesnek bizonyul. Annak ellenére, hogy a foglalkozás többdimenziós jelenségként is felfogható (Róbert 1997) a fiatalok esetében szükség van egy sokrétübb (Ferge 2012) többdimenziós elemzésre. (Savage et al. 2013; Albert et al. 2017)

A következö rész (7. fejezet) azt vizsgálja, hogy (1) milyen demográfiai tényezők hatnak a fiatalok státushelyzetére (nem, életkor, településtípus), illetve (2) milyen hatással van a fiatalok státusára a származás (apa iskolai végzettsége, foglalkozása). 
Egy státusindexet szerkesztettünk, három dimenzió - lakáskörülmények, az anyagi-vagyoni helyzet és szabadidő - felhasználásával és ezt követően regressziós modellek segítségével vizsgáltuk a magyarázó tényezőket.

A regressziós modellek alapján mindkét évben az iskolai végzettség, különösen a felsőfokú végzettség a legfontosabb, az apa foglalkozása csak a vezetők esetében szignifikáns. A településtípus és státus között 2001-ben mértünk statisztikai összefüggést, az életkor és a nem kisebb mértékben ugyan, de szintén szignifikáns összefüggést mutat a társadalmi státushelyzetre. Eredményeink Treiman modernizációs tézisével is összecsengenek, miszerint az iskolai végzettségnek a foglalkozásra gyakorolt hatása erősebb, míg az apa foglalkozásának szerepe csökkent.

A státushelyzet társadalmi faktorait vizsgálva arra a megállapításra jutunk, hogy mind a hagyományos rétegváltozók (foglalkozás, iskolai végzettség) mind pedig a szocio-demográfiai tényezők (nem, életkor, település) fontos szerepet töltenek be a fiatalok szegmentációjában. Az örökölt státus - különösen az iskolai végzettség változatlanul fontos marad, és a kulturális tőke továbbra is az egyik legfontosabb státusmeghatározó tényező. Bukodi (2010) is szignifikáns tényezőként emeli ki a család szerepét, különösen az apa státusát, a posztszocialista országokban, úgy véli, hogy a kulturális fogyasztás alakulását legerösebben az iskolai végzettség befolyásolja (Bukodi 2010).

Az elemzés központi része a 8 . fejezet, mely során az erdélyi magyar fiatalok kulturális szegmentációját mutattuk be a különböző szabadidős események (magas, illetve populáris kulturális események) tükrében. Célunk az volt, hogy több módszer alkalmazásával (hierarchikus és nem hierarchikus klaszterelemzéssel is megvizsgáltuk a csoportösszetételt) vizsgáljuk meg a társadalmi rétegződés szakirodalmában megjelenő „omnivore-univore” elmélet érvényességét az erdélyi magyar fiatalok körében.

(1) Mennyire érvényes az erdélyi magyar fiatalok körében az a tézis, mely szerint a „kulturális mindenevőség” felbukkanása feloszlatja az osztályalapú megkülönböztetést a kulturális fogyasztás tekintetében?

Mindkét klaszterelemzési módszerrel négy látens életstílus-csoportot határoztunk meg, a screenagerek (1), a (magas)kultúra orientáltak (2), a ,mindenevök” (3), 
illetve a passzívak (4) csoportját, amelyeket fogyasztói magatartásuk alapján jellemeztük. Azt találtuk, hogy a fiatalok társadalmi struktúrában elfoglalt helyzete többdimenziós térben tagozódik. Van egy réteg a passzívak csoportja (25\%), akiknél a kulturális fogyasztás mértéke meglehetősen alacsony, vagyis a fogyasztói miliők alatt helyezkednek el. Ök azok, akiknek nincs meg a Zinecker-i értelemben vett játékterük arra, hogy kulturális tőkét halmozzanak fel. Elemzésünk azt is mutatja, hogy van egyfajta átalakulás a kulturális sokszínüség felé, a kulturális fogyasztás nem korlátozódik a magaskultúrára, megjelenik egy új fogyasztói csoport, a „mindenevők” csoportja. Összességében a mindenevőség magas státusú fogyasztói stílus, ami az iskolázottság, a foglalkozási pozíció, illetve életkor alapján differenciálódik. Ezek az eredmények összhangban vannak a korábbi kutatások eredményeivel (Chan-Goldthorpe 2005, 2007b; Warde-Wright-Modesto 2007; Bukodi 2010; Sági 2010; Yoo Jin-Kyoung Nan 2013; Coulangeon-Roharik 2014, 2014; Croitoru-Becuț 2017; Kristóf-Kmetty 2019)

Azt is mondhatnánk, hogy a magaskultúra fogyasztása egy úgynevezett omnivore formában is megjelenik a fiatalok körében. Azonban a mindenevőség megjelenése nem tekinthető bizonyítéknak Bourdieu kulturális megkülönböztetés-elméletének irrelevanciájára, inkább egy empirikus megnyilvánulás a fiatalok körében megjelenő fogyasztói változásokról. A szélesebb kulturális és társadalmi változásokat tükrözi, de ugyanakkor horizontálisan és vertikálisan egyaránt megkülönbözteti a társadalmi csoportokat (Hanquinet 2017).

További kutatási kérdéseink a kulturális fogyasztás és a társadalmi háttér kapcsolatára irányultak. (1) Milyen kulturális fogyasztásbeli jellegzetességek alapján különülnek el az erdélyi magyar fiatalok? (2) Milyen tényezők befolyásolják a kulturális fogyasztási szokásaikat, a különböző fogyasztói csoportokba való tartozást?

Azt feltételeztük, hogy elemzésünknek két kimenetele lehet: ha nincs kapcsolat a klasztertagság és a független változók között, akkor valóban igaz az, hogy a fogyasztás szerinti szegmentációnak nincs köze a klasszikus réteghelyzethez (a homológia tézis teljesen megdőlt). Vagy van összefüggés, ami azt jelenti, hogy mégsem individualizáltak az egyenlőtlenségek, tehát a horizontális fogyasztói tagolódás nem váltotta fel a vertikálisat. 
Az elemzések azt bizonyítják, hogy a fiatalok kulturális szegmentációját mind az apa iskolai végzettsége, mind pedig a jelenlegi foglalkozása befolyásolja: minél magasabb az apa iskolai végzettsége, annál nagyobb az esély arra, hogy a megkérdezett a magas kultúra orientáltak, illetve a mindenevők csoportjába tartozzon, emellett a vezető beosztású vagy egyéni vállalkozók gyerekei szintén nagyobb valószínűséggel tartoznak a mindenevők csoportjába. A magasabb státusú fiatalok között nagyobb valószínüséggel alakulnak ki onmivore fogyasztási minták, tehát a társadalmi rétegeződés és a kultúrafogyasztás közötti viszonyt az iskolázottság és a foglalkozás is befolyásolja. Ugyanakkor a fogyasztói csoportok formálásában nagyon lényeges szerepe van az életkornak (Schulze 2000; Kristóf-Kmetty 2019) és az életciklusnak, különösen a mindenevők csoportjában.

\subsection{Következtetések}

Visszatérve a fő kutatási kérdésünkhöz, nagyon nehéz állást foglalni azzal kapcsolatban, hogy melyik elmélet vagy melyik osztályozás a jobb, de többnyire konszenzus van abban, hogy a társadalom többdimenziós térben tagolódik, és mi is úgy gondoljuk, hogy a fiatalok társadalmi rétegződését nem, vagy csak korlátok között lehet egyetlen modellel leírni. Elemzésünk rámutat arra, hogy a hagyományos rétegződési mutatók ugyan differenciálnak, de a fiatalok rétegződésének leírásához ezek nem elégségesek. A fiatal korosztályok esetében nem beszélhetünk homogén jövedelmi osztályokról, ők azok, akik inkább életstílus, illetve fogyasztás szerint rétegződnek, ezért fontosnak tartjuk, hogy a hagyományos társadalmi struktúraelemzésekkel párhuzamosan nagyobb teret kapjanak az életstílus elemek.

A jelenlegi erdélyi magyar fiatalok kulturális szegmentációjában a vertikális és horizontális differenciálódás együttesen van jelen, az „életstílus csoportok még nem váltották le egyértelműen a hagyományos osztály modelleket” (Bukodi-Róbert, 2000:363; Marian, 2010:85), de elemzésünk következtetése, hogy a fogyasztói társadalom megjelenése megváltoztatta a fiatalok kulturális rétegződésének dinamikáját, és a horizontális differenciálódás vizsgálata és az életstílus tipológiák további fontos 
kutatási irányt jelentenek. Véleményünk szerint az ifjúságkutatásban a vertikális és horizontális értelmezési kereteket együtt kell használni. Bourdieu (1984) elméletéből kiindulva, aki a gazdasági tőke mellett a kiemeli a kulturális és a társadalmi tőke fontosságát is, mi is egy többdimenziós modell megalapozását, kidolgozását javasoljuk. Viszont az „osztályok” fogalmának használatát, különösen a fiatalok esetében, igencsak problémásnak gondoljuk, különösen akkor ha egyetértünk Éber azon észrevételével, miszerint osztályelemzésen nem a népességből vett minta megfigyelt elemeinek osztályozását kell érteni, hanem inkább társadalmi és gazdasági, termelési viszonyok értelmezését (Éber 2015, 2020). Bourdieu sem beszél valós, aktuálisan létező osztályokról, legfeljebb „,valószínüségi osztályokról. (Bourdieu 2013). Ferge hasonlóképpen csak zárójelben használja az osztály kifejezést: „Igen nagy bajban vagyok az „osztály” kategóriájával. Emlékeim szerint rétegződésről és struktúráról sokat írtam, de a társadalmi osztály fogalmat többé-kevésbé zárójelben használtam” (Ferge 2012).

\subsection{A kutatás korlátai és további kérdések}

Az elemzésünk egyik hiányosságaként kell megemlítenünk, hogy nem sikerült részletesen kitérjünk az etnikai sajátosságokra. A román nyelvü fiatalok empirikus vizsgálatát azért nem fogalmaztuk meg célként, mert a Magyar Ifjúság 2016-os kutatás során nem volt román alminta, így nem volt lehetőségünk az összehasonlításra.

Elméleti vonatkozásban azt láthattuk, hogy egyfajta párhuzamosság jellemzi az erdélyi magyar és erdélyi román fiatalokat, de ugyanakkor az erdélyi magyar és magyarországi fiatalokat is. Az erdélyi fiatalok esetében az ifjúsági korszakváltás erősebben osztályspecifikus, mint a magyarországi fiatalok esetében (Ercsei 2006; Veres 2006). Az erdélyi magyar fiatalok körében olyan kulturális és civilizatorikus tényezők hatnak (hagyományos női-férfi szerepek, vallásosság), amelyek lelassították ezt a folyamatot. Gábor Kálmán állítása szerint az eltérő etnikumú fiatalok eltérő utat járnak be. Bár a román fiatalokra is éppen úgy jellemző a származási különbségek meghatározó szerepe, mint a romániai magyar fiatalokra, ezek kevésbé érvényesülnek, 
gyengébben hatnak (Gábor-Veres 2011). A fiatalok értékorientációját, illetve élettervezésüket elemezve azt mutatták ki, hogy a román fiatalok közelebb állnak a magyarországi magyar fiatalokhoz, mint a romániai magyar fiatalokhoz, azaz a román fiatalok körében erőteljesebb individualizáció következett be, mint az erdélyi magyar fiatalok körében. (Gábor 2005; Gábor-Veres 2011) Kulturális fogyasztás tekintetében a két etnikum eltérő intenzitású fogyasztói mintázata arra vezethető vissza, hogy az erdélyi magyarok valahol a magyarországi, illetve a romániai kulturális habitusok között helyezkednek el (Barna 2011).

Kevés az olyan elemzés, amely a román-magyar fiatalok szegmentációját párhuzamosan elemzi, hogy miben tér el az erdélyi magyar fiatalok kulturális szegmentációja a határon belüli magyarok, illetve a román fiatalok kulturális sajátosságától. A kisebbségi lét további sajátosságainak feltárása és mélyebb elemzése fontos eredmény az erdélyi magyar szakirodalomban. Tehát a kutatás egyik fontos kiterjesztése lehetne az etnikai, azaz kisebbségi-többségi dimenzió használata.

Az elemzés kiterjesztésének egy másik lehetősége a digitális dimenzió, az internethasználat és kultúrafogyasztás összefüggéseinek elemzése. A technológiai forradalom, a számitógéphasználat globális léptékü, így az élet minden aspektusában változtatásokat hozott. A változások a kultúrafogyasztási szokások alakulására is döntő hatással vannak. Tehát fontos kérdés, hogy a szabadidő és élménytársadalom mellett kiépülő információs társadalom milyen hatást gyakorolt a társadalmi egyenlőtlenségek rendszerére, milyen mértékben változtatja meg a fiatalok kulturális fogyasztását az internethasználat és mennyiben járul hozzá az egyenlőtlenségek csökkenéséhez, vagy éppen ellenkezőleg, ennek növeléséhez.

Jelen dolgozat célja nem egy nagyszabású rétegződés- vagy miliőkutatás elvégzése volt, célunk nem a fiatalok „osztályokba” vagy „rétegekbe” sorolása, inkább arra fektettük a hangsúlyt, hogy megvizsgáljuk, az elmúlt tizenöt évben milyen változások mentek végbe a fiatalok szegmentációjában. Arra törekedtünk, hogy egy többdimenziós megközelítésben írjuk le a fiatalok szegmentációját, a régi és az új struktúraképző elemek együttes alkalmazásával. Tehát a régi és az új struktúraképző elemeket összehangolva vázoltuk fel a századforduló után végbement, fiatalok tagozódásában megfigyelt változásokat. 
A dolgozat célja volt, hogy bekapcsolódjon abba a vitába, ami a „paradigmaváltás” vagy a „régi modell” megújításának dilemmájáról szól, és hozzájáruljon ahhoz a társadalomkép kialakulásához, amely az egyenlötlenségek összetett és többdimenziós jellegének feltárását szorgalmazza. 


\section{Mellékletek}

\subsection{Szocio-demográfiai jellemzők 2001 és 2016 között. Táblázatok, ábrák}

10.1. táblázat: Főbb szocio-demográfiai változók 2001 és 2016-ban

\begin{tabular}{|l|c|c|c|}
\hline \multicolumn{1}{|c|}{ Szocio-demográfiai változók } & MOZAIK 2001 & Ifjúság 2016 & Eltérés \\
\hline Nem & & & \\
\hline Férfi & 49 & 52.3 & 3.3 \\
\hline Nő & 51 & 47.7 & -3.3 \\
\hline Településtípus & & & \\
\hline Város & 67.2 & 48.5 & -18.7 \\
\hline Község, falu & 32.8 & 51.5 & 18.7 \\
\hline Családi állapot & & & \\
\hline nőtlen, hajadon, egyedül él & 72.1 & 77.3 & 5.2 \\
\hline házas & 23.7 & 13.6 & -10.1 \\
\hline élettársa van & 2.8 & 8.7 & 5.9 \\
\hline elvált & 1.3 & 0.3 & -1 \\
\hline özvegy, egyedül él & 0.1 & 0.1 & 0 \\
\hline Korcsoport & & & \\
\hline $15-19$ & 30.8 & 33 & 2.2 \\
\hline $20-24$ & 36.6 & 33 & -3.6 \\
\hline $25-29$ & 32.5 & 34 & 1.5 \\
\hline Iskolai Végzettség & & & \\
\hline általános iskola & 26.5 & 33.5 & 7 \\
\hline szakiskola & 15.6 & 8.7 & -6.9 \\
\hline Szakközépiskola* & 9.8 & 12.6 & 2.8 \\
\hline elméleti líceum, középfokú tanítóképzés & 31.4 & 21.9 & -9.5 \\
\hline technikum, posztliceális & 5.5 & 2.7 & -2.8 \\
\hline föiskola & 2.7 & 1.5 & -1.2 \\
\hline egyetem & .3 & 14.7 & 6.7 \\
\hline magiszteri képzés & & 3.9 & 3.6 \\
\hline PhD, egyéb posztgraduális képzés & & 0.4 & 0.3 \\
\hline & & & \\
\hline & & & \\
\hline
\end{tabular}

*szakközépiskolai érettségi, középfokú technikum 2016 
10.2. táblázat: Főbb szocio-demográfiai változók 2001 és 2015-ben

\begin{tabular}{|c|c|c|c|}
\hline Szocio-demográfiai változók & MOZAIK 2001 & GeneZYs 2015 & Eltérés \\
\hline \multicolumn{4}{|l|}{$\mathrm{Nem}$} \\
\hline Férfi & 49 & 51 & -2 \\
\hline Nő & 51 & 49 & 2 \\
\hline \multicolumn{4}{|l|}{ Településtípus } \\
\hline Város & 67.2 & 49.8 & 17.4 \\
\hline Község, falu & 32.8 & 50.2 & -17.4 \\
\hline \multicolumn{4}{|l|}{ Családi állapot } \\
\hline nőtlen, hajadon, egyedül él & 72.1 & 48.4 & 23.7 \\
\hline házas & 23.7 & 15.2 & 8.5 \\
\hline nem házas, de együtt él valakivel & & 9.3 & \\
\hline van párkapcsolata, de nem élnek együtt & & 26.4 & \\
\hline elvált & 1.3 & 0.4 & 0.9 \\
\hline özvegy, egyedül él & 0.1 & 0.2 & -0.1 \\
\hline élettársa van & 2.8 & & \\
\hline \multicolumn{4}{|l|}{ Korcsoport } \\
\hline $15-19$ & 30.8 & 28.4 & 2.4 \\
\hline $20-24$ & 36.6 & 36.4 & 0.2 \\
\hline $25-29$ & 32.5 & 35.2 & -2.7 \\
\hline \multicolumn{4}{|l|}{ Iskolai Végzettség } \\
\hline általános iskola & 26.5 & 28.6 & -2.1 \\
\hline szakiskola & 15.6 & 11.6 & 4 \\
\hline Szakközépiskola* & 9.8 & & \\
\hline elméleti líceum, középfokú tanítóképzés & 31.4 & 31.5 & -0.1 \\
\hline technikum, posztliceális & 5.5 & 2.7 & 2.8 \\
\hline föiskola & 2.7 & & \\
\hline egyetem & 8.0 & 17.3 & -9.3 \\
\hline magiszteri képzés & .3 & 8.1 & -7.8 \\
\hline $\mathrm{PhD}$, egyéb posztgraduális képzés & .1 & 0.2 & -0.1 \\
\hline
\end{tabular}

* szakközépiskolai érettségi, középfokú technikum 2016 
10.3. táblázat: Szubjektív jólét szocio-demográfiai ismérvek szerinti eloszlása. Mozaik 2001

\begin{tabular}{|l|c|c|c|c|c|}
\hline & $\begin{array}{c}\text { Nélkülözések } \\
\text { között élnek }\end{array}$ & $\begin{array}{c}\text { Hónapról hó- } \\
\text { napra anyagi } \\
\text { gondjaik van- } \\
\text { nak }\end{array}$ & $\begin{array}{c}\text { Éppen, hogy ki- } \\
\text { jönnek jövedel- } \\
\text { mükböl }\end{array}$ & $\begin{array}{c}\text { Beosztással } \\
\text { jól kijönnek }\end{array}$ & $\begin{array}{c}\text { Gondok } \\
\text { nélkül } \\
\text { élnek }\end{array}$ \\
\hline Településtípus* & & & & & \\
\hline Megyeszékhely & 2.2 & 8.1 & 34.3 & 48.3 & 7.0 \\
\hline Más város & 2.0 & 10.5 & 37.5 & 40.2 & 9.8 \\
\hline Falu & 4.3 & 8.0 & 38.8 & 44.7 & 4.3 \\
\hline Nem n.sz & & & & & \\
\hline Férfi & 4.2 & 10.9 & 35.4 & 43.6 & 5.9 \\
\hline Nő & 3.7 & 10.8 & 38.2 & 41.1 & 6.2 \\
\hline Apa iskolai végzettsége*** & & & & & \\
\hline Általános iskola/szakiskola & 4.2 & 11.9 & 40.5 & 38.5 & 4.9 \\
\hline Elméleti líceum/föiskola & 1.3 & 8.6 & 29.8 & 52.7 & 7.5 \\
\hline Egyetemi végzettség & 1.7 & 5.7 & 29.3 & 50.6 & 12.6 \\
\hline Apa foglalkozása*** & & & & & \\
\hline Alkalmazottként dolgozik & 2.7 & 8.6 & 36.2 & 46.5 & 5.9 \\
\hline Saját vállalkozásban & 3.0 & 8.0 & 16.0 & 54.0 & 19.0 \\
\hline Gazdaságilag inaktív & 3.2 & 10.5 & 41.5 & 40.0 & 4.8 \\
\hline $\begin{array}{l}\text { Gazadaságban dolgozik, al- } \\
\text { kalmi munkából él meg }\end{array}$ & 6.1 & 18.2 & 37.9 & 32.6 & 5.3 \\
\hline Foglalkozás*** & & & & & \\
\hline Tanul & 1.3 & 8.0 & 33.9 & 47.9 & 8.9 \\
\hline Dolgozik & 3.7 & 10.1 & 40.1 & 41.0 & 5.1 \\
\hline Egyik sem & 9.3 & 19.4 & 34.3 & 34.6 & 2.5 \\
\hline
\end{tabular}

Khi négyzetek:16.396; 2.116; 59.727; 90.416; 88,059; Cramer`s V: 0.084, 0.033, 0.131, 0.115, 0.155

$* \mathrm{p}<0.05 ; * * \mathrm{p}<0.01 ; * * * \mathrm{p}<0.000$; 
10.4. táblázat: Szubjektív jólét szocio-demográfiai ismérvek szerinti eloszlása. Magyar Ifjúság 2016

\begin{tabular}{|c|c|c|c|c|c|}
\hline & $\begin{array}{l}\text { Nélkülözé- } \\
\text { sek között } \\
\text { élnek }\end{array}$ & $\begin{array}{l}\text { Hónapról hó- } \\
\text { napra anyagi } \\
\text { gondjaik van- } \\
\text { nak }\end{array}$ & $\begin{array}{l}\text { Éppen, hogy } \\
\text { kijönnek jö- } \\
\text { vedelmükböl }\end{array}$ & $\begin{array}{l}\text { Beosztás- } \\
\text { sal jól ki- } \\
\text { jönnek }\end{array}$ & $\begin{array}{l}\text { Gondok } \\
\text { nélkül él- } \\
\text { nek }\end{array}$ \\
\hline \multicolumn{6}{|l|}{ Településtípus nsz. } \\
\hline Megyeszékhely & 1.4 & 3.2 & 18.4 & 57.1 & 20.0 \\
\hline Más város & 0.2 & 2.5 & 13.6 & 59.7 & 24.0 \\
\hline Falu & 0.3 & 2.7 & 15.9 & 59.4 & 21.7 \\
\hline \multicolumn{6}{|l|}{ Nem n.sz } \\
\hline Férfi & 0.6 & 2.8 & 15.3 & 59.5 & 21.7 \\
\hline Nő & 0.4 & 2.6 & 16.9 & 58.3 & 21.7 \\
\hline \multicolumn{6}{|l|}{ Apa iskolai végzettsége ${ }^{* * *}$} \\
\hline Általános iskola/szakiskola & 0.7 & 4.1 & 17.9 & 60.5 & 16.7 \\
\hline Elméleti líceum/föiskola & 0.3 & 1.1 & 14.7 & 59.7 & 24.1 \\
\hline Egyetemi végzettség & 0.9 & 1.4 & 6.5 & 50.5 & 40.7 \\
\hline \multicolumn{6}{|l|}{ Apa foglalkozása*** } \\
\hline fizikai & 0.6 & 3.4 & 16.7 & 60.9 & 18.4 \\
\hline szellemi & 0.4 & 1.5 & 9.8 & 57.1 & 31.2 \\
\hline vezető & 0.6 & 0 & 7.2 & 52.1 & 40.1 \\
\hline \multicolumn{6}{|l|}{ Foglalkozás*** } \\
\hline Tanul & 0.7 & 2.6 & 12.6 & 58.0 & 26.0 \\
\hline Dolgozik & 0.5 & 2.3 & 18.1 & 61.4 & 17.6 \\
\hline Egyik sem & 0.9 & 6.1 & 27.8 & 47.8 & 17.4 \\
\hline
\end{tabular}

Khi négyzetek:13.342; 1.147; 80.112; 66.358; 42.732 Cramer`s V: $0.059 ; 0,025 ; 0.150 ; 0.139 ; 0.108$

$* \mathrm{p}<0,05 ; * * \mathrm{p}<0,01 ; * * * \mathrm{p}<0.000$; 
10.5. táblázat: A fiatalok munkaerőpiaci helyzete. MOZAIK 2001

\begin{tabular}{|c|c|c|}
\hline & Dolgozik-e, fötevékenység? MOZAIK 2001 & \\
\hline \multicolumn{3}{|l|}{ Tanul - 29.5} \\
\hline & általános iskola & .5 \\
\hline & szakiskola & 1.5 \\
\hline & szakközépiskola & 3.4 \\
\hline & elméleti líceum, középfokú tanítóképzés & 10.5 \\
\hline & technikum, posztliceális & 1.5 \\
\hline & főiskola & 1.8 \\
\hline & egyetem & 9.8 \\
\hline & magiszteri képzés & .1 \\
\hline & $\mathrm{PhD}$, egyéb posztgraduális képzés & .2 \\
\hline & $\begin{array}{l}\text { egyéb tanfolyamot végez, nem iskolarendszerben ta- } \\
\text { nul }\end{array}$ & .1 \\
\hline & felvételi előkészítőre jár & .1 \\
\hline \multicolumn{3}{|l|}{ Dolgozik - 52.8} \\
\hline & alkalmazottként dolgozik & 40.2 \\
\hline & saját vállalkozásban dolgozik & 1.6 \\
\hline & vállalkozásban segítő családtag & .6 \\
\hline & szellemi szabadfoglalkozású & .9 \\
\hline & a családi gazdaságban dolgozik & 3.8 \\
\hline & alkalmi munkákból, megbízásokból él & 4.0 \\
\hline & jövedelmeiből él & .1 \\
\hline & Feketemunkából & 1.6 \\
\hline \multicolumn{3}{|l|}{$\begin{array}{l}\text { Egyik sem } \\
\text { vagy egyéb - } \\
17.8\end{array}$} \\
\hline & sorkatona & .9 \\
\hline & $\begin{array}{l}\text { Gyes, Gyed, Gyermekgondozási Támogatás, szülési } \\
\text { szabadság }\end{array}$ & 2.3 \\
\hline & háztartásbeli & 3.3 \\
\hline & eltartott & 1.7 \\
\hline & öregségi nyugdíjas & .1 \\
\hline & leszázalékolt, rokkantnyugdíjas, betegnyugdíjas & .1 \\
\hline & szociális segélyezett & .5 \\
\hline & egyéb inaktív & .3 \\
\hline & munkanélküli járadékos, segélyezett & 3.6 \\
\hline & munkanélküli járadék nélkül & 5.0 \\
\hline
\end{tabular}


10.6. táblázat: A fiatalok munkaerőpiaci helyzete. Magyar Ifjúság 2016

\begin{tabular}{|l|c|c|}
\hline Ön jelenleg? Főtevékenységét tekintve? Ifjúság 2016 & $(\mathrm{N}=1925)$ \\
\hline $\begin{array}{l}\text { Tanul, részt vesz valamilyen szervezett, iskolarendszerü képzés- } \\
\text { ben (N=964) }\end{array}$ & & 50.1 \\
\hline Emellett dolgozik is & & \\
\hline $\begin{array}{l}\text { Dolgozik, akár bejelentve, akár nem, akár alkalmazottként, akár } \\
\text { alkalmazottként, akár vállalkozóként (N=843) }\end{array}$ & \multirow{2}{*}{16.5} & \\
\hline $\begin{array}{l}\text { Emellett tanul, részt vesz valamilyen szervezett iskolarendszer- } \\
\text { ben, képzésben }\end{array}$ & & 6.2 \\
\hline vagy egyik sem? (N=118) & $18.7(\mathrm{~N}=62) 0.6$ & \\
\hline munkanélküli, segélyt kap & $43.6(\mathrm{~N}=55) 1.2$ & \\
\hline munkanélküli, ellátás nélkül & $50.4(\mathrm{~N}=70) 1.8$ & \\
\hline háztartásbeli, otthon van a gyerekkel (ellátás nélkül) & $63.9(\mathrm{~N}=65) 2.1$ & \\
\hline eltartott, otthon van & $5.5(\mathrm{~N}=50) 0.1$ & \\
\hline rokkantnyugdíjas, rokkantjáradékos & $5.5(\mathrm{~N}=50) 0.1$ & \\
\hline Szociális segélyezett & $42.8(\mathrm{~N}=70) 1.5$ & \\
\hline Gyermeknevelési szabadság & & \\
\hline
\end{tabular}

10.7. táblázat: Iskolai végzettség településtipus szerint

\begin{tabular}{|l|c|c|c|c|c|c|}
\hline & $\begin{array}{c}\text { Megyeszék- } \\
\text { hely } \\
2001\end{array}$ & $\begin{array}{c}\text { Megyeszék- } \\
\text { hely } \\
2016\end{array}$ & $\begin{array}{c}\text { Más vá- } \\
\text { ros } \\
2001\end{array}$ & $\begin{array}{c}\text { Más vá- } \\
\text { ros } \\
2016\end{array}$ & $\begin{array}{c}\text { Község, } \\
\text { falu } \\
2001\end{array}$ & $\begin{array}{c}\text { Község, } \\
\text { falu } \\
2016\end{array}$ \\
\hline $\begin{array}{l}\text { legfeljebb 8 osz- } \\
\text { tály }\end{array}$ & 35.2 & 22.6 & 19.4 & 21.7 & 45.4 & 55.8 \\
\hline $\begin{array}{l}\text { szakmunkás- } \\
\text { képző }\end{array}$ & 31.9 & 7.0 & 16.6 & 15.2 & 51.5 & 77.8 \\
\hline érettségi & 51.8 & 26.4 & 25.5 & 24.1 & 22.9 & 49.5 \\
\hline $\begin{array}{l}\text { Felsőfokú vég- } \\
\text { zettség }\end{array}$ & 65.7 & 42.5 & 20.0 & 20.0 & 14.3 & 37.5 \\
\hline
\end{tabular}

MOZAIK $2001 \mathrm{~N}=1184$, Cramer`s V : 0.214 SIG < 0.000; Ifjúság $2016 \mathrm{~N}=1979$ Cramer`s V : 0.169 $\mathrm{SIG}<0.000$

10.8. táblázat: Kulturális fogyasztás. Hány könyvet olvasott?

\begin{tabular}{|l|c|c|c|c|c|}
\hline MOZAIK 2001 & egyet sem & $1-10$ & $11-20$ & $21-40$ & 41 fölött \\
\hline Vállalkozó & 26.2 & 61.9 & 4.8 & 2.4 & 4.8 \\
\hline Értelmiségi & 8.2 & 54.8 & 19.2 & 6.8 & 11.0 \\
\hline nem fizikai munkás & 24.4 & 53.2 & 11.4 & 7.0 & 4.0 \\
\hline Szakmunkás & 47.9 & 41.1 & 4.6 & 2.3 & 4.2 \\
\hline Gazdálkodó & 68.1 & 27.8 & 4.2 & & \\
\hline $\begin{array}{l}\text { szakképzetlen, alkalmi } \\
\text { munkás }\end{array}$ & 55.4 & 36.1 & 2.4 & 0.6 & 5.4 \\
\hline $\begin{array}{l}\text { munkanélküli } \\
\text { Tanul }\end{array}$ & 35.4 & 46.0 & 9.9 & 3.1 & 5.6 \\
\hline
\end{tabular}


10.9. táblázat: Kulturális fogyasztás: Kifejezetten turisztikai céllal utazott-e az elmúlt évben?

\begin{tabular}{|l|c|c|c|c|}
\hline & MOZAIK 2001 & $\begin{array}{c}\text { Magyar Ifjúság } \\
2016\end{array}$ & MOZAIK 2001 & $\begin{array}{c}\text { Magyar Ifjú- } \\
\text { ság 2016 }\end{array}$ \\
\hline & \multicolumn{3}{|c|}{ Igen } & \multicolumn{2}{c|}{ Nem } \\
\hline Vállalkozó & 4.9 & 71.8 & 95.1 & 28.2 \\
\hline Értelmiségi & 21.5 & 55.1 & 78.5 & 44.9 \\
\hline nem fizikai munkás & 6.8 & 48.4 & 93.2 & 51.6 \\
\hline Szakmunkás & 3.1 & 34.8 & 96.9 & 65.2 \\
\hline Gazdálkodó & & 45.8 & 100.0 & 54.2 \\
\hline $\begin{array}{l}\text { szakképzetlen, alkalmi } \\
\text { munkás }\end{array}$ & 3.9 & 26.4 & 96.1 & 73.6 \\
\hline munkanélküli & 3.1 & 31.2 & 96.9 & 68.8 \\
\hline Tanul & 10.5 & 52.9 & 89.5 & 47.1 \\
\hline Összesen & 7.7 & 47.8 & 92.3 & 52.2 \\
\hline
\end{tabular}

10.1 ábra: Fiatalok szubjektív jóléte 2001-2016 között (saját szerkesztés)

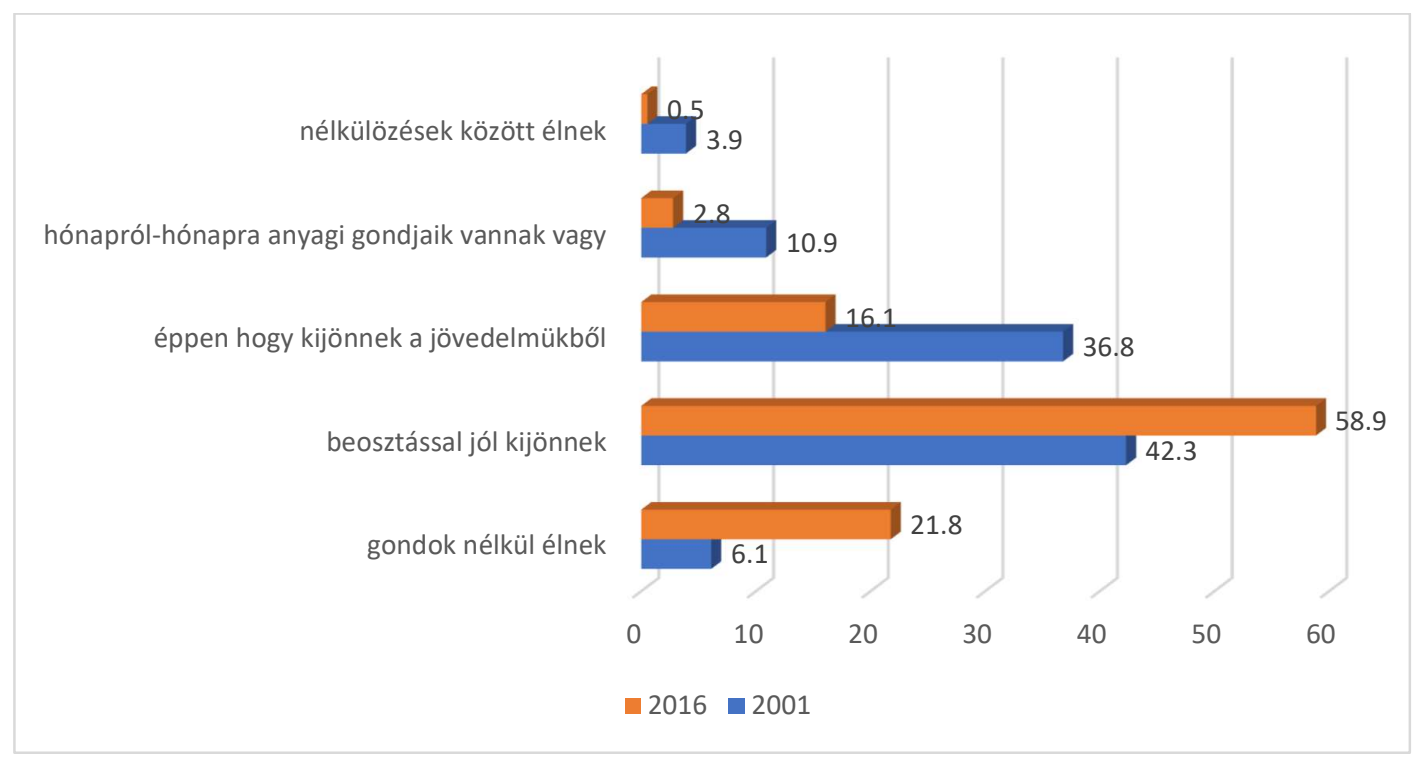


10.2. ábra: Erdélyi magyar fiatalok számának változása 2002-2015 között. Forrás: Nemzeti Statisztikai Hivatal (saját szerkesztés)

Magyar fiatalok számának változása 2002-2015 közōtt

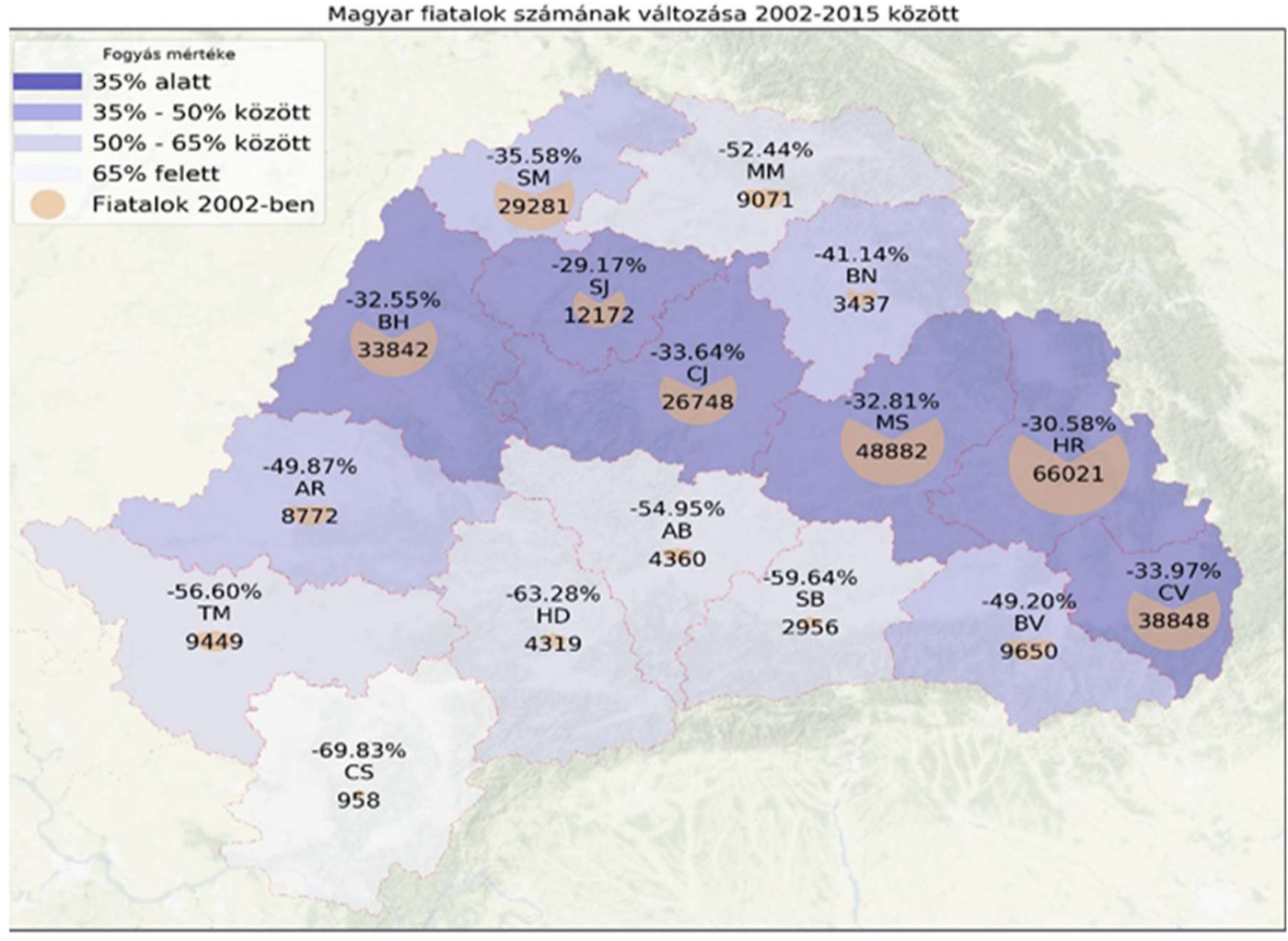


10.10. táblázat: Kulturális tevékenységeken való részvétel az Európai Unió tagországaiban. Az elmúlt egy hónapban legalább egyszer részt vett az alábbi tevékenységeken:\%

\begin{tabular}{|l|c|c|c|c|c|c|c|}
\hline & $\begin{array}{c}\text { könyvet ol- } \\
\text { vasott }\end{array}$ & mozi & $\begin{array}{c}\text { múzeum, ki- } \\
\text { álítás }\end{array}$ & $\begin{array}{c}\text { kon- } \\
\text { cert }\end{array}$ & $\begin{array}{c}\text { könyv- } \\
\text { tár }\end{array}$ & $\begin{array}{c}\text { szín- } \\
\text { ház }\end{array}$ & $\begin{array}{c}\text { balett vagy } \\
\text { opera }\end{array}$ \\
\hline & -3 & 1 & -4 & -2 & -4 & -4 & 0 \\
\hline EU 27 - 2013 & 68 & 52 & 37 & 35 & 31 & 28 & 18 \\
\hline EU 27 - 2007 & 71 & 51 & 41 & 37 & 35 & 32 & 18 \\
\hline SE & 90 & 74 & 76 & 61 & 74 & 53 & 34 \\
\hline DK & 82 & 76 & 62 & 60 & 63 & 38 & 25 \\
\hline EE & 78 & 46 & 46 & 54 & 47 & 45 & 25 \\
\hline FR & 73 & 63 & 39 & 33 & 33 & 21 & 25 \\
\hline NL & 86 & 70 & 60 & 51 & 45 & 53 & 23 \\
\hline LV & 72 & 43 & 49 & 55 & 39 & 43 & 24 \\
\hline LU & 76 & 61 & 49 & 52 & 17 & 35 & 29 \\
\hline LT & 66 & 41 & 39 & 51 & 35 & 34 & 23 \\
\hline MT & 55 & 51 & 37 & 32 & 29 & 24 & 18 \\
\hline SI & 67 & 43 & 36 & 50 & 48 & 33 & 15 \\
\hline SK & 68 & 40 & 31 & 40 & 26 & 30 & 15 \\
\hline UK & 80 & 61 & 52 & 37 & 47 & 39 & 22 \\
\hline FI & 75 & 50 & 40 & 47 & 66 & 42 & 17 \\
\hline DE & 79 & 54 & 44 & 45 & 23 & 30 & 19 \\
\hline ES & 60 & 49 & 29 & 31 & 33 & 21 & 15 \\
\hline BE & 65 & 54 & 40 & 36 & 37 & 32 & 22 \\
\hline BG & 55 & 29 & 26 & 30 & 18 & 24 & 11 \\
\hline CZ & 71 & 47 & 37 & 36 & 28 & 36 & 15 \\
\hline IE & 74 & 61 & 40 & 43 & 45 & 31 & 17 \\
\hline AT & 73 & 59 & 42 & 52 & 22 & 40 & 18 \\
\hline PL & 56 & 40 & 24 & 22 & 26 & 16 & 10 \\
\hline PT & 40 & 29 & 17 & 19 & 15 & 13 & 8 \\
\hline IT & 56 & 53 & 30 & 26 & 24 & 24 & 17 \\
\hline CY & 54 & 30 & 18 & 30 & 8 & 23 & 9 \\
\hline RO 2013 & 51 & 20 & 21 & 25 & 17 & 15 & 11 \\
\hline RO 2007 & 58 & 22 & 27 & 28 & 22 & 20 & 8 \\
\hline & -7 & -2 & -6 & -3 & -5 & -5 & 3 \\
\hline HU & 60 & 33 & 28 & 26 & 19 & 20 & 10 \\
\hline EL & 50 & 36 & 16 & 23 & 10 & 24 & 9 \\
\hline HR & 34 & 29 & 36 & 31 & 22 & 12 \\
\hline
\end{tabular}

Forrás: Special Eurobarometer 399. Cultural acces and participation. Report. Pp.12 
10.3. ábra: Fiatalok szabadidö-kulturális fogyasztása - 2001 (saját szerkesztés)

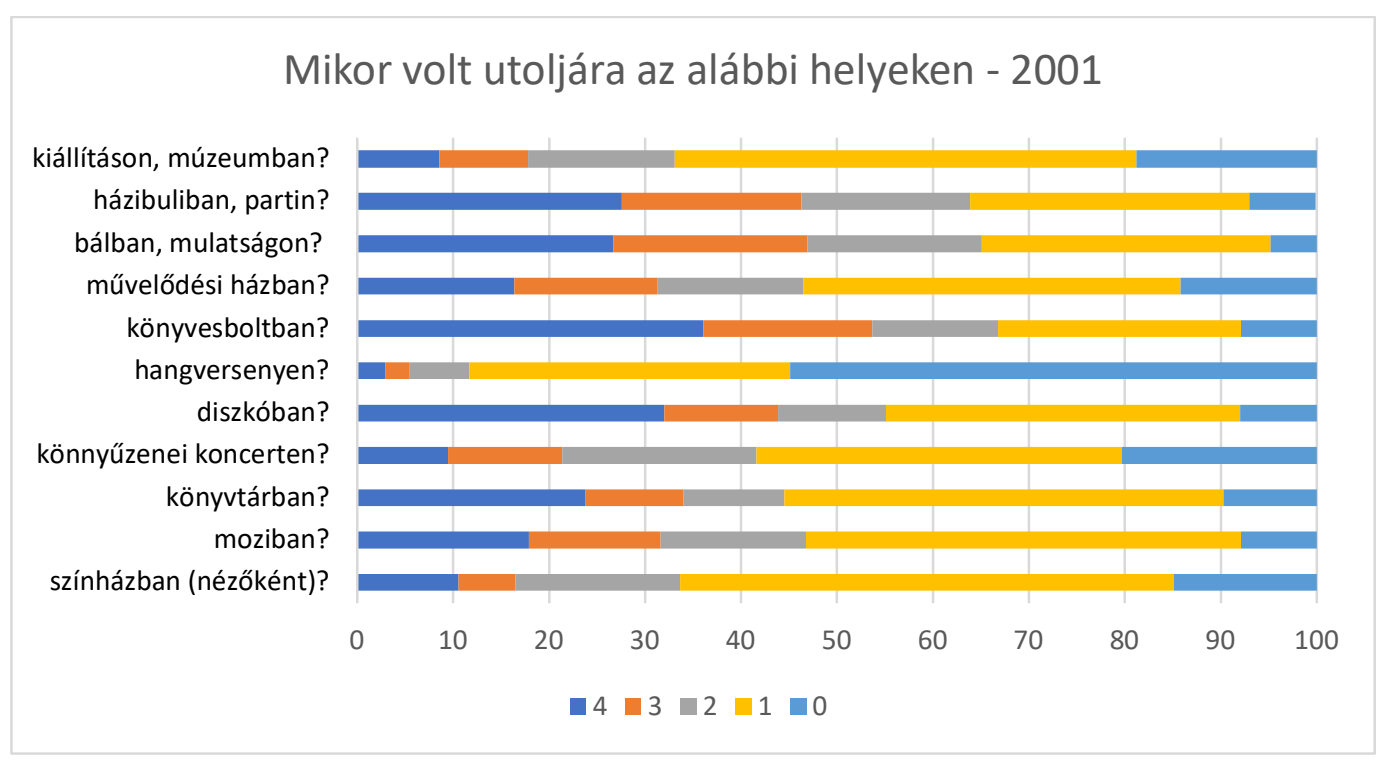

10.4. ábra: Fiatalok szabadidős-kulturális fogyasztása - 2016 (saját szerkesztés)

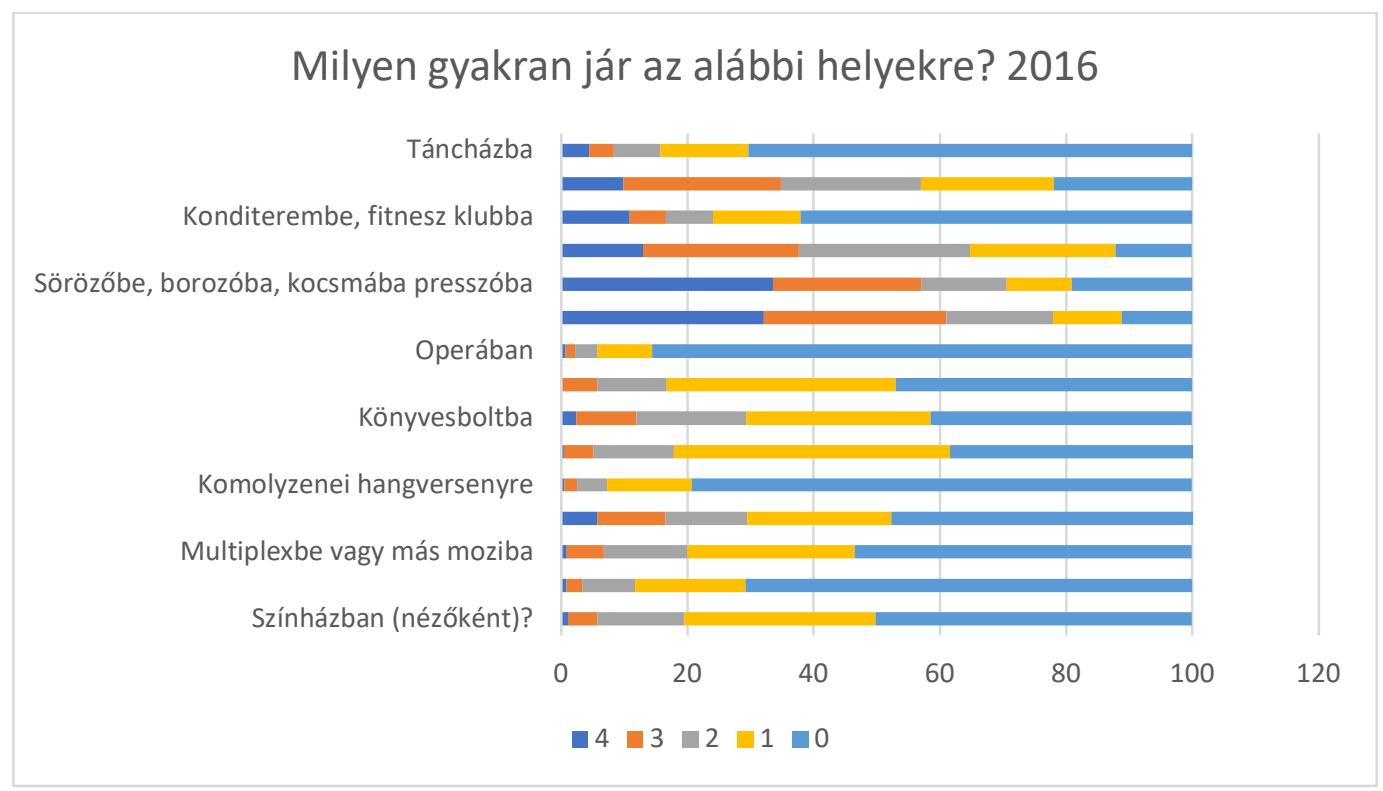




\subsection{Mintavételi leírások}

\subsubsection{Mintavételi leírás MOZAIK 2001. Belső Erdély és Székelyföld}

A felmérés vizsgálati területe Belső Erdély és Partium magyarok lakta települései, illetve Székelyföld. Belső Erdélyben, tág értelemben vett Erdély 13 megyéje, valamint Maros megye mezőségi része Marosvásárhellyel. ${ }^{63}$

Az alapsokaságot 2001. január elsején 15-29 éves magyar nemzetiségü népesség képezi az alábbi erdélyi megyékből (lásd. 10.11. táblázat). Ezek, az 1992-es népszámlálás alapján, az akkori 5-éves korcsoportok alapján elkülöníthető, 2001-ben 1529 éves magyar nemzetiségü népesség, összesen 213.367 személy.

A minta összeállításánál a kutatók úgy határozták meg az elemszámot, hogy minden régióban legyen lehetőség az adatok önálló elemzésére is. Véletlen mintavételi eljárást alkalmaztak (lépcsőzetes mintavétel, területi bontásban reprezentatív, kvótás-sétálós, háztartás-beazonosítással bővítve).

A lépcsők a következők: anyanyelvi hovatartozás, a település típusa (megyeközpont, más városok, községek, falvak). Az esetszámok leosztása lépcsőkre az 1992-es népszámlálás, a 1999-es Román Statisztikai évkönyv (legfrissebb), 1998-2000-es Magyar Statisztikai Évkönyvek vándorlási adatai és a 2000-es Romániai Magyar Évkönyv természetes népmozgalmi adatainak segítségével történt. (Csata-Magyari-Veres 2002).

10.11. táblázat: Az alappopuláció megyék szerint-Forrás: 1992. évi népszámlálási adatok

\begin{tabular}{|l|c|l|l|c|}
\hline \multicolumn{1}{|c|}{ Megye } & 15-29 éves magyarok & & \multicolumn{1}{c|}{ Megye } & 15-29 éves magyarok \\
\hline Fehér & 5073 & & Máramaros & 11187 \\
\hline Arad & 12437 & & Maros ${ }^{1}$ & 33954 \\
\hline Bihar & 36893 & & Szatmár & 28609 \\
\hline B-Naszód & 4323 & & Szilágy & 12895 \\
\hline Brassó & 12917 & & Szeben & 3914 \\
\hline Krassó-Szörény & 1655 & & Temes & 12945 \\
\hline Kolozs & 29690 & & Kovászna & $*$ \\
\hline Hunyad & 6875 & & Hargita & $*$ \\
\hline & & & Erdély összesen & 213367 \\
\hline
\end{tabular}

\footnotetext{
${ }^{63}$ A romániai magyarok 65 százaléka él ebben a régióban.
} 
A megyénkénti leosztást az 1992-es adatokból kiindulva, a 2000-es Romániai Magyar Évkönyvben közölt természetes fogyási arányszámokkal (1996-ig voltak adatok) korrigálták.

A településtípusok szerinti arányok megyékként (megyeszékhely, más város, községek) a magyar népességre az 1992-es adatok alapján van meg, ezt korrigálták azzal az eltéréssel, ami országos szinten az 1999-es Román Statisztikai Évkönyv alapján a 15-29 évesek és az össznépesség között megfigyelhető: 3\%-kal több városi, ebből 2\% megyeszékhely).

A minta végrehajtása:

A kérdőbiztosok a véletlen lépésszám mellett kvótakövetéssel választják ki az alanyokat. A kvóták a korcsoportokat és a nemet követik településenként.

Háztartások beazonosítása:

1. Lépésszámmal: tömbmagyar, vagy $75 \%$ fölötti magyarsággal rendelkező településen. Lépésszámmal, az egyszerü mechanikus kiválasztás szabálya szerint, osztva a lakosságszámot a települési mintakerettel. Ha túl nagy a lépésszám (20 fölött), akkor az osztódik még 2-vel vagy 4-el.

2. Lépésszámmal, ahol a magyarok aránya 75 - $30 \%$ között van, a lépésszám 4.

3. Tisztán kvótásan, ahol a magyarok aránya kevesebb, mint 30 százalék, az utcák pontos meghatározásával.

10.12. táblázat: A minta felbontva település-típusonként

\begin{tabular}{|l|c|c|c|c|}
\hline Megye & Összesen & Megye-központ & Más város & Községek \\
\hline Fehér & 29 & 4 & 13 & 12 \\
\hline Arad & 71 & 36 & 8 & 26 \\
\hline Bihar & 211 & 91 & 40 & 80 \\
\hline Beszterce-Naszód & 25 & 8 & 3 & 14 \\
\hline Brassó & 74 & 43 & 12 & 19 \\
\hline Krassó-Szörény & 9 & 2 & 6 & 1 \\
\hline Kolozs & 170 & 91 & 33 & 46 \\
\hline Hunyad & 40 & 9 & 30 & 1 \\
\hline Máramaros & 64 & 32 & 5 & 27 \\
\hline Maros (Mezöség) & 194 & 101 & 50 & 43 \\
\hline Szatmár & 163 & 77 & 11 & 75 \\
\hline Szilágy & 74 & 16 & 16 & 42 \\
\hline Szeben & 22 & 5 & 14 & 3 \\
\hline Temes & 74 & 36 & 18 & 20 \\
\hline Összesen & 1220 & 511 & 238 & 371 \\
\hline
\end{tabular}


A székelyföldi minta kialakításánál szintén az 1992-es népszámlálási adatókból indultak ki, településtípus, nem és korcsoportok szerint kialakított reprezentatív minta. A székelyföldi települések közigazgatásilag három különböző megyéhez tartoznak. Hargita, Kovászna és Maros megye keleti része. A mintába olyan magyar többségü települések kerültek, ahol a magyarság aránya meghaladja az 50 százalékot, az így kapott 444 település képezte a mintavételi alapegységet. Ezeket öt paraméter alapján különböző településtípusokba sorolták, és a csoportokon belül véletlenszerüen választották be a településeket. A csoportosítás alapját az alábbi kritériumok jelentették: regionális elkülönülések, település nagysága, illetve lakosság száma, közigazgatási besorolás és megközelíthetőség. (Bálint-Demeter 2002)

10.13. táblázat: A mintába került települések. Székelyföld. Forrás: Bálint Blanka-Demeter, 2001

\begin{tabular}{|l|c|c|c|c|}
\hline $\begin{array}{c}\text { Közigazgatási } \\
\text { besorolás }\end{array}$ & Város & Községközpont & Falu & Összesen \\
\hline Hargita & 3 & 5 & 5 & 13 \\
\hline Kovászna & 3 & 2 & 2 & 7 \\
\hline Maros & 1 & 2 & 2 & 5 \\
\hline Összesen & 7 & 9 & 9 & 25 \\
\hline
\end{tabular}

A háztartáson belül a megkérdezetteket nem és életkor szerinti kvóta alapján választották ki. Az eredmények 95 százalékos valószínűséggel \pm 2,3 százalékos hibahatáron belül mozognak.

\subsubsection{Mintavételi leírás. GeneZYs 2015}

Erdélyben a GeneZYs 2015 ifjúságszociológiai kutatás vizsgálati területét Erdély 16 megyéje ${ }^{64}$ jelentette, ezen belül pedig a magyarok által is lakott települések. Az alapsokaságot az említett 16 megyében élő magyar anyanyelvü 15-29 év közötti népesség képezte. Ez összesen 227.648 föt jelent, a csoport szocio-demográfiai öszszetétele nem, korcsoport, lakóhely típusa és régió szerint, amint az a 10.14-es táblázatban látható.

A megkérdezetteket rétegzett, véletlenszerü mintavételi eljárással választották ki. Először a településeket rétegezték régió, településméret és etnikai arány szerint és az így kialakított 21 tényleges rétegből véletlenszerüen választottak településeket. Azokon a településeken, ahol nem volt egységes a házszámozás, véletlenszerüen választottak utcákat, szintén figyelembe véve azt, hogy az adott utcákban hányan laknak.

${ }^{64}$ Arad, Bihar, Beszterce-Naszód, Brassó, Hargita, Krassó-Szörény, Kolozs, Kovászna, Hunyad, Fehér, Máramaros, Maros, Szatmár, Szilágy, Szeben, Temes. 
A háztartások kiválasztása a megadott utcán belül egységesen 1-es lépték segítségével történt, a szórvány jellegü településeken (20 százalék alatt) megengedett volt, hogy a kiválasztott utcában tetszöleges sorrendben kérdezzék le a magyar fiatalokat (Papp Z. et al. 2017).

10.14. táblázat: Az alappopuláció eloszlása nem, életkor, lakhely típusa és régió szerint. Forrás: Papp Z. et al. 2017.

\begin{tabular}{|c|c|c|c|c|c|c|}
\hline Településtí- & $\mathrm{Nem}$ & Életkor & & & & \\
\hline & & & Székelyföld & $\begin{array}{c}\text { Közép Er- } \\
\text { dély }\end{array}$ & Partium & Szórvány \\
\hline \multirow{9}{*}{ Város } & \multirow{4}{*}{ Férfi } & $15-19$ & 4.503 & 4.162 & 4.581 & 1.937 \\
\hline & & $20-24$ & 5.859 & 6.764 & 6.126 & 2.796 \\
\hline & & $25-29$ & 6.481 & 5.473 & 6.221 & 2.830 \\
\hline & & Összesen & 16.843 & 16.399 & 16.928 & 7.563 \\
\hline & \multirow{4}{*}{ Nö } & $15-19$ & 4.279 & 4.229 & 4.426 & 1.747 \\
\hline & & $20-24$ & 5.776 & 7.222 & 5.870 & 2.371 \\
\hline & & $25-29$ & 6.380 & 5.275 & 6.106 & 2.444 \\
\hline & & Összesen & 16.453 & 16.726 & 16.402 & 6.562 \\
\hline & Összes & & 33.296 & 33.125 & 33.330 & 14.125 \\
\hline \multirow{9}{*}{ Falu } & \multirow{4}{*}{ Férfi } & $15-19$ & 6.962 & 3.973 & 5.362 & 1.508 \\
\hline & & $20-24$ & 8.643 & 4.526 & 5.976 & 1.674 \\
\hline & & $25-29$ & 8.658 & 4.444 & 5.829 & 1.601 \\
\hline & & Összesen & 24.263 & 12.943 & 17.167 & 4.783 \\
\hline & \multirow{4}{*}{ Nö } & $15-19$ & 6.754 & 3.764 & 5.077 & 1.314 \\
\hline & & $20-24$ & 7.954 & 4.202 & 5.645 & 1.466 \\
\hline & & $25-29$ & 7.709 & 4.188 & 5.205 & 1.338 \\
\hline & & Összesen & 22.417 & 12.154 & 15.927 & 4.118 \\
\hline & Összes & & 46.680 & 25.097 & 33.094 & 8.901 \\
\hline Összesen & & 227.648 & 79.976 & 58.222 & 66.424 & 23.026 \\
\hline
\end{tabular}

A háztartáson belül a megkérdezetteket nem és életkor szerinti kvóta segítségével kellett kiválasztani. Az eredmények 95 százalékos valószínüséggel $\pm 2,9$ százalékos hibahatáron belül mozognak. 


\subsubsection{Mintavételi leírás. Magyar Ifjúság Kutatás 2016}

Az alapsokaságot 15-19 éves magyar nemzetiségü népesség képezi a 2011. népszámlálás alapján, az alábbi 16 erdélyi megyéből (lásd.10.30 táblázat), összesen 209.175 magyar fiatal.

A mintavétel módja: szigorított véletlen sétás rétegzett mintavétel. A szigorítás életkori csoportok és nemek szerint történt (szabad kvóták). A mintát először megyék szerint rétegezték a 15-29 éves korú magyar népesség 2011. évi népszámlálási lélekszámának alapján, ezt követően pedig településtípus szerint (Székely 2018).

10.15. táblázat: Az alappopuláció megyék szerint-Forrás: 2001. évi népszámlálási adatok

\begin{tabular}{|l|c|l|c|}
\hline \multicolumn{1}{|c|}{ Megye } & 15-29 éves magyarok & \multicolumn{1}{c|}{ Megye } & 15-29 éves magyarok \\
\hline Fehér & 1998 & Kolozs & 19679 \\
\hline Brassó & 5381 & Máramaros & 4526 \\
\hline Kovászna & 26989 & Szatmár & 20017 \\
\hline Hargita & 48608 & Szilágy & 8830 \\
\hline Maros & 34379 & Arad & 4608 \\
\hline Szeben & 1309 & Krassó-Szörény & 315 \\
\hline Bihar & 24281 & Hunyad & 1588 \\
\hline B-Naszód & 2042 & Összesen & 209175 \\
\hline
\end{tabular}

A városokat két csoportba sorolták (megyeszékhely, többi kisváros) a községeket pedig, a magyarság aránya, néprajzi-földrajzi és szociológiai jellegzetességek alapján csoportosították. A lehatárolt területi-etnográfiai csoportokból választották ki a településeket egyszerü véletlen kiválasztással. P1. Hargita megyében a községeket három csoportba osztották: Csíkszék, Udvarhelyszék és Gyergyószék szerint.

A mintavétel során a nagy tömbben élő magyarság körében pl. Székelyföldön a véletlen sétához 2-4-es lépésszám ${ }^{65}$ is társult. A kérdezők szigorúan ezen házszám szerinti lakásba kérdeztek. Ez a módszer Partium (Bihar, Szatmár) és a több mint 80\%ban magyarlakta településeken is érvényes volt. Nem magyar többségü településeken (Marosvásárhely, Szászrégen stb.) a lépésszám egy volt, tehát a kérdező egy adott

${ }^{65}$ A lépésszám során a házszámok az irányadók. Ha egy házszám alatt maximum 4 háztartás/lakás van, onnan csak egy fiatal kérdezhető le. Ha a házszám/tömbház/társasház több, mint 4 lakásos, a lakrészek száma is a lépésszám részét képezik, tehát alkalmazni kell a lépésszámot. 
utcacsoport vagy falu végigjárása során minden egyes olyan lakásba bemehetett, ahol magyarok élnek.

A háztartáson belül a megkérdezetteket nem és életkor szerinti kvóta segítségével választották ki. Az eredmények 95 százalékos valószínüséggel $\pm 2,24$ százalékos hibahatáron belül mozognak.

\subsection{Szabadidős tevékenységekre,}

\section{kulturális fogyasztásra vonatkozó kérdések}

\subsubsection{Mikor volt ön utoljára? MOZAIK 2001}

\begin{tabular}{|l|c|c|c|c|c|}
\hline & $\begin{array}{c}1 \text { hónapon be- } \\
\text { lül }\end{array}$ & $\begin{array}{c}1-2 \text { hó- } \\
\text { napja }\end{array}$ & 4-6 hónapja & $\begin{array}{c}\text { ennél ré- } \\
\text { gebben }\end{array}$ & soha \\
\hline Színházban (nézöként) & 1 & 2 & 3 & 4 & 9 \\
\hline Moziban & 1 & 2 & 3 & 4 & 9 \\
\hline Könyvtárban & 1 & 2 & 3 & 4 & 9 \\
\hline Könnyüzenei koncerten & 1 & 2 & 3 & 4 & 9 \\
\hline Diszkóban & 1 & 2 & 3 & 4 & 9 \\
\hline Hangversenyen & 1 & 2 & 3 & 4 & 9 \\
\hline Könyvesboltban & 1 & 2 & 3 & 4 & 9 \\
\hline Müvelödési házban & 1 & 2 & 3 & 4 & 9 \\
\hline Bálban, mulatságon & 1 & 2 & 3 & 4 & 9 \\
\hline Házibuliban, partin & 1 & 2 & 3 & 4 & 9 \\
\hline Kiállításon, múzeumban & 1 & 2 & 3 & 4 & 9 \\
\hline $\begin{array}{l}\text { Nemzeti Parkban, természet- } \\
\text { védelmi területen? }\end{array}$ & 1 & 2 & 3 & 4 & 9 \\
\hline
\end{tabular}




\subsubsection{Milyen gyakran szoktad az alábbi tevékenységeket folytatni?}

\section{GeneZYs 2015}

\begin{tabular}{|c|c|c|c|c|c|c|c|c|c|c|}
\hline & \multicolumn{2}{|c|}{ soha } & \multirow[b]{2}{*}{3} & \multirow[b]{2}{*}{4} & \multirow[b]{2}{*}{5} & \multirow[b]{2}{*}{6} & \multirow[b]{2}{*}{7} & \multirow[b]{2}{*}{8} & \multicolumn{2}{|c|}{$\begin{array}{l}\text { nagyon } \\
\text { gyakran }\end{array}$} \\
\hline & 1 & 2 & & & & & & & 9 & 10 \\
\hline Kirándulni a természetben & 1 & 2 & 3 & 4 & 5 & 6 & 7 & 8 & 9 & 10 \\
\hline Könyvtárba járni & 1 & 2 & 3 & 4 & 5 & 6 & 7 & 8 & 9 & 10 \\
\hline Zenélni-festeni-rajzolni & 1 & 2 & 3 & 4 & 5 & 6 & 7 & 8 & 9 & 10 \\
\hline Facebookon-twitteren lógni & 1 & 2 & 3 & 4 & 5 & 6 & 7 & 8 & 9 & 10 \\
\hline Színházba járni & 1 & 2 & 3 & 4 & 5 & 6 & 7 & 8 & 9 & 10 \\
\hline Hangversenyre operába járni & 1 & 2 & 3 & 4 & 5 & 6 & 7 & 8 & 9 & 10 \\
\hline Táncházba járni & 1 & 2 & 3 & 4 & 5 & 6 & 7 & 8 & 9 & 10 \\
\hline $\begin{array}{l}\text { Filmeket nézni otthon (PC- } \\
\text { laptop-tablet) }\end{array}$ & 1 & 2 & 3 & 4 & 5 & 6 & 7 & 8 & 9 & 10 \\
\hline $\begin{array}{l}\text { Írni (saját blogot, verset v. } \\
\text { prózát) }\end{array}$ & 1 & 2 & 3 & 4 & 5 & 6 & 7 & 8 & 9 & 10 \\
\hline Könyvet olvasni & 1 & 2 & 3 & 4 & 5 & 6 & 7 & 8 & 9 & 10 \\
\hline Sportolni, kocogni & 1 & 2 & 3 & 4 & 5 & 6 & 7 & 8 & 9 & 10 \\
\hline Tévét nézni & 1 & 2 & 3 & 4 & 5 & 6 & 7 & 8 & 9 & 10 \\
\hline Zenét hallgatni & 1 & 2 & 3 & 4 & 5 & 6 & 7 & 8 & 9 & 10 \\
\hline Híreket olvasni online & 1 & 2 & 3 & 4 & 5 & 6 & 7 & 8 & 9 & 10 \\
\hline Újságot, híreket olvasni & 1 & 2 & 3 & 4 & 5 & 6 & 7 & 8 & 9 & 10 \\
\hline Online játékot használni & 1 & 2 & 3 & 4 & 5 & 6 & 7 & 8 & 9 & 10 \\
\hline $\begin{array}{l}\text { Barátokkal együtt lógni, be- } \\
\text { szélgetni }\end{array}$ & 1 & 2 & 3 & 4 & 5 & 6 & 7 & 8 & 9 & 10 \\
\hline $\begin{array}{l}\text { Kocsmába, sörözőbe, boro- } \\
\text { zóba járni }\end{array}$ & 1 & 2 & 3 & 4 & 5 & 6 & 7 & 8 & 9 & 10 \\
\hline Moziba járni & 1 & 2 & 3 & 4 & 5 & 6 & 7 & 8 & 9 & 10 \\
\hline Klubokba, partykra járni & 1 & 2 & 3 & 4 & 5 & 6 & 7 & 8 & 9 & 10 \\
\hline $\begin{array}{l}\text { Szakkörön, képzéseken részt } \\
\text { venni }\end{array}$ & 1 & 2 & 3 & 4 & 5 & 6 & 7 & 8 & 9 & 10 \\
\hline Szoláriumba járni & 1 & 2 & 3 & 4 & 5 & 6 & 7 & 8 & 9 & 10 \\
\hline $\begin{array}{l}\text { Kozmetikushoz, fodrászhoz } \\
\text { járni }\end{array}$ & 1 & 2 & 3 & 4 & 5 & 6 & 7 & 8 & 9 & 10 \\
\hline Uszodába vagy szaunába járni & 1 & 2 & 3 & 4 & 5 & 6 & 7 & 8 & 9 & 10 \\
\hline $\begin{array}{l}\text { Fitness szalonba, kondi-te- } \\
\text { rembe járni }\end{array}$ & 1 & 2 & 3 & 4 & 5 & 6 & 7 & 8 & 9 & 10 \\
\hline Chatelni & 1 & 2 & 3 & 4 & 5 & 6 & 7 & 8 & 9 & 10 \\
\hline Plázába járni & 1 & 2 & 3 & 4 & 5 & 6 & 7 & 8 & 9 & 10 \\
\hline
\end{tabular}




\subsubsection{Milyen gyakran jár Ön a következő helyekre?}

\section{Magyar Ifjúság Kutatás 2016}

\begin{tabular}{|l|c|c|c|c|c|c|}
\hline & $\begin{array}{c}\text { Hetente } \\
\text { többször }\end{array}$ & $\begin{array}{c}\text { Hetente } \\
\text { egyszer }\end{array}$ & $\begin{array}{c}\text { Havonta } \\
\text { többször }\end{array}$ & $\begin{array}{c}2-3 \text { ha- } \\
\text { vonta }\end{array}$ & $\begin{array}{c}\text { Évente } \\
\text { többször }\end{array}$ & $\begin{array}{c}\text { (szinte) } \\
\text { soha }\end{array}$ \\
\hline Színházba & 1 & 2 & 3 & 4 & 5 & 9 \\
\hline $\begin{array}{l}\text { Art moziba, / müvész- } \\
\text { filmeket nézni }\end{array}$ & 1 & 2 & 3 & 4 & 5 & 9 \\
\hline $\begin{array}{l}\text { Multiplexbe vagy más } \\
\text { moziba }\end{array}$ & 1 & 2 & 3 & 4 & 5 & 9 \\
\hline Könyvtárba & 1 & 2 & 3 & 4 & 5 & 9 \\
\hline $\begin{array}{l}\text { Komolyzenei hangver- } \\
\text { senyre }\end{array}$ & 1 & 2 & 3 & 4 & 5 & 9 \\
\hline $\begin{array}{l}\text { Könnyűzenei kon- } \\
\text { certre }\end{array}$ & 1 & 2 & 3 & 4 & 5 & 9 \\
\hline Könyvesboltba & 1 & 2 & 3 & 4 & 5 & 9 \\
\hline Kiállításra, múzeumba & 1 & 2 & 3 & 4 & 5 & 9 \\
\hline Operába & 1 & 2 & 3 & 4 & 5 & 9 \\
\hline Kávézóba, teázóba & 1 & 2 & 3 & 4 & 5 & 9 \\
\hline $\begin{array}{l}\text { Sörözőbe, borozóba, } \\
\text { kocsmába presszóba }\end{array}$ & 1 & 2 & 3 & 4 & 5 & 9 \\
\hline Étterembe & 1 & 2 & 3 & 4 & 5 & 9 \\
\hline $\begin{array}{l}\text { Konditerembe, fitnesz } \\
\text { klubba }\end{array}$ & 1 & 2 & 3 & 4 & 5 & 9 \\
\hline Plázába (mallba) & 1 & 2 & 3 & 4 & 5 & 9 \\
\hline Táncházba & 1 & 2 & 3 & 4 & 5 & 9 \\
\hline
\end{tabular}

\subsection{Klaszterek meghatározása K-Means módszerrel.}

\section{Fogyasztói csoportok leírása:}

A K-means klaszterelemzéssel szintén 4 csoportot hoztunk létre. Ezt követően a tízfokú skálán mért kulturális aktivitási formákat dummy változókká alakítottuk, (14-ig nem szokta az alábbi tevékenységeket végezni, illetve 5-10 igen), és egy kereszttábla segítségével mutatjuk be a csoportok jellemzőit a 10.16. táblázatban. 
10.16. táblázat: Kulturális aktivitások gyakorisága - fogyasztási szegmensek szerint (\%)

\begin{tabular}{|c|c|c|c|c|c|}
\hline & Screenagerek & $\begin{array}{l}\text { Magaskultúra } \\
\text { orientáltak }\end{array}$ & Mindenevök & Passzívak & Együtt \\
\hline kirándulni a természetbe & 68 & 81.2 & 90.6 & 33.9 & 67.2 \\
\hline könyvtárba járni & 5.1 & 45 & 45.5 & 3.4 & 22.7 \\
\hline zenélni/festeni/rajzolni & 23.2 & 65.9 & 64 & 11.9 & 39 \\
\hline $\begin{array}{l}\text { Facebookon/twitteren lógni, } \\
\text { posztolni }\end{array}$ & 97.4 & 81.4 & 98.5 & 48.7 & 82.2 \\
\hline színházba járni & 15.1 & 54.3 & 64.9 & 3.4 & 32 \\
\hline hangversenyre, operába járni & 1.1 & 18.2 & 22.7 & 0.9 & 9.7 \\
\hline táncházba járni & 6.6 & 26.9 & 33 & 3 & 16.1 \\
\hline $\begin{array}{l}\text { filmeket nézni otthon } \\
\text { (PC/Laptop/Tablet) }\end{array}$ & 94.5 & 87.1 & 95.5 & 46.4 & 80.7 \\
\hline írni (blogot, verset, prózát) & 6.6 & 26.3 & 23.6 & 0.4 & 13.3 \\
\hline könyvet olvasni & 24.3 & 75.1 & 82.7 & 11.1 & 45.3 \\
\hline sportolni, kocogni & 61.6 & 67.8 & 87.1 & 17.9 & 57.4 \\
\hline tévét nézni & 78.3 & 40.9 & 73.9 & 66.8 & 65.9 \\
\hline zenét hallgatni & 98.2 & 94.2 & 99 & 80 & 92.8 \\
\hline $\begin{array}{l}\text { újságot, } \\
\text { híreket olvasni }\end{array}$ & 39.7 & 66.3 & 82.2 & 22 & 50.5 \\
\hline híreket olvasni online & 47.6 & 81.8 & 91.6 & 15.3 & 56.8 \\
\hline online játékot használni & 46.3 & 20.1 & 43.8 & 8.9 & 30.3 \\
\hline $\begin{array}{l}\text { barátokkal együtt lógni, be- } \\
\text { szélgetni }\end{array}$ & 95.2 & 90 & 99 & 62.6 & 86.5 \\
\hline $\begin{array}{l}\text { kocsmába/sörözőbe/borozóba } \\
\text { járni }\end{array}$ & 51.5 & 45.7 & 71.4 & 25.1 & 47.8 \\
\hline moziba járni & 22.1 & 29.2 & 52.5 & 3.4 & 25.6 \\
\hline klubokba, partykra járni & 47.2 & 26.8 & 86.2 & 7.2 & 41 \\
\hline $\begin{array}{l}\text { szakkörön, képzéseken részt } \\
\text { venni }\end{array}$ & 11 & 35.1 & 48 & 3.8 & 22.8 \\
\hline szoláriumba járni & 4 & 5.7 & 16.3 & 0.8 & 6.3 \\
\hline $\begin{array}{l}\text { kozmetikushoz, fodrászhoz } \\
\text { járni }\end{array}$ & 31.2 & 28.7 & 71.3 & 9.8 & 34 \\
\hline uszodába vagy szaunába járni & 13.6 & 24.5 & 45 & 1.3 & 19.8 \\
\hline $\begin{array}{l}\text { fitness-szalonba, kondi-te- } \\
\text { rembe járni }\end{array}$ & 15.1 & 24 & 38.6 & 2.1 & 19 \\
\hline chatelni & 88.9 & 54.1 & 96.6 & 19.1 & 64.7 \\
\hline plázába járni & 43.5 & 27.9 & 78.7 & 8.5 & 38 \\
\hline
\end{tabular}

Az első klaszter a „, screenagerek” csoportja, a fiatalok közel 30\%-a tartozik ide, akiknek aktivitásuk nagyon szorosan kapcsolódik az internet, illetve a képernyők világához. Nagyon nagy arányban aktív Facebook-felhasználók. Jellemző rájuk, hogy otthon néznek filmeket a számítógépen, zenét hallgatnak és chat-elnek, illetve elég 
gyakori tevékenységként jelenik meg az online játékok használata is. A magas kultúrát megjelenítő tevékenységek, mint a színház, opera, hangverseny, könyvtár látogatása, illetve könyvolvasás jóval kevésbé jellemző erre a csoportra, mint a következő két klaszterbe tartozó fiatalokra.

A második klasztert a ,, magaskultúra orientáltak” csoportja (22,7\%) alkotja. A fiatalok ezen szegmensére jellemző a színházlátogatás, hangverseny, opera, táncházak látogatása. Továbbá az olyan kreatív tevékenységek, mint zenélés, festés, rajzolás, írás (saját blog vagy vers) ebben a klaszterben jelenik meg a leghangsúlyosabban. A könyvárba járás, illetve a könyvolvasás is hasonlóan magas gyakoriságot mutatnak.

A harmadik csoportot, ami arányaiban megegyezik az előző csoporttal hisz mindkettőbe a fiatalok 23 illetve 22\%-a tartozik, a „,mindenevők” csoportjának neveztük el. A fiatalok ezen részére jellemző, hogy a vizsgált aktivitások mindegyikében részt vesznek. Magas részvételt figyelhetünk meg mind a magas kulturális tevékenységekben, mind pedig a közösségi média használatában és ugyanakkor a kocsmába, sörözőbe, plázába járás is jellemző rájuk.

A negyedik csoport a ,passzivak” (25,6\%) csoportja. Azok a fiatalok tartoznak ide, akiknek a fö tevékenységük elsősorban a zenehallgatás és tévénézés, illetve barátokkal való együtt lógás. Kis arányban jellemző még rájuk, a Facebook-használat, illetve a laptopon való filmnézés, azonban minden más vizsgált tevékenység messze alulmarad a többi klasztereken belül folytatott gyakoriságától.

A klaszterek társadalmi- demográfiai jellemzői a 10.17. táblázatban láthatóak. 
10.17. táblázat: Társadalmi demográfiai csoportok kulturális klasztereken belüli aránya $(\%)$

\begin{tabular}{|c|c|c|c|c|c|c|}
\hline $\begin{array}{l}\text { Társadalmi-demográ- } \\
\text { fiai csoport }\end{array}$ & Screenagerek & $\begin{array}{c}\text { Magaskultúra } \\
\text { orientáltak }\end{array}$ & Mindenevők & Passzívak & Együtt & $\begin{array}{c}\text { Cramer`s } \\
\mathrm{V}\end{array}$ \\
\hline $\mathrm{Nem}$ & & & & & & 0.212 \\
\hline Nő & 35.8 & 55.0 & 63.9 & 44.9 & 48.7 & \\
\hline Férfi & 64.2 & 45.0 & 36.1 & 55.1 & 51.3 & \\
\hline Településtípus & & & & & & 0.174 \\
\hline Falu & 48.5 & 41.3 & 46.3 & 64.7 & 50.5 & \\
\hline Város & 51.5 & 58.7 & 53.7 & 35.3 & 49.5 & \\
\hline Korcsoport & & & & & & 0.194 \\
\hline 15-19 évesek & 32.7 & 19.2 & 43.3 & 17.9 & 28.2 & \\
\hline 20-24 évesek & 37.9 & 40.9 & 35.5 & 30.6 & 36.2 & \\
\hline 25-29 évesek & 29.4 & 39.9 & 21.2 & 51.5 & 35.6 & \\
\hline Iskolai végzettség & & & & & & 0.222 \\
\hline Legfeljebb 8 osztály & 27.2 & 14.4 & 27.6 & 44.1 & 28.7 & \\
\hline Szakiskola & 13.6 & 3.8 & 5.9 & 20.3 & 11.4 & \\
\hline $\begin{array}{l}\text { Érettségi (líceum, } \\
\text { technikum) }\end{array}$ & 39.3 & 35.6 & 38.9 & 23.8 & 34.4 & \\
\hline $\mathrm{BA}, \mathrm{MA}, \mathrm{PhD}$ & 19.9 & 46.2 & 27.6 & 11.5 & 25.4 & \\
\hline Apa iskolai végzettség & & & & & & 0.266 \\
\hline Legfeljebb 8 osztály & 7.0 & 5.4 & 4.3 & 37.4 & 13.3 & \\
\hline Szakiskola & 39.7 & 28.3 & 33.5 & 33.8 & 34.3 & \\
\hline $\begin{array}{l}\text { Érettségi (líceum, } \\
\text { technikum) }\end{array}$ & 42.8 & 38.0 & 40.5 & 25.3 & 37.0 & \\
\hline $\mathrm{BA}, \mathrm{MA}, \mathrm{PhD}$ & 10.5 & 28.3 & 21.6 & 3.5 & 15.3 & \\
\hline Foglalkozás & & & & & & 0.277 \\
\hline $\begin{array}{l}\text { Beosztott, alkalmazott } \\
\text { (nem közszférában) }\end{array}$ & 28.5 & 25.2 & 19.5 & 24.2 & 24.7 & \\
\hline $\begin{array}{l}\text { Beosztott, alkalmazott } \\
\text { közszférában }\end{array}$ & 10.4 & 17.8 & 6.0 & 13.4 & 11.8 & \\
\hline Vezető beosztású & 3.0 & 2.5 & 4.0 & 0.9 & 2.5 & \\
\hline $\begin{array}{l}\text { Alkalmi munkából él } \\
\text { meg }\end{array}$ & 5.6 & 1.5 & 2.0 & 11.3 & 5.3 & \\
\hline $\begin{array}{l}\text { Egyéni vállalkozó, } \\
\text { társtulajdonos }\end{array}$ & 2.6 & 4.0 & 1.0 & 3.0 & 2.7 & \\
\hline Tanuló, egyetemista & 36.3 & 37.6 & 60.5 & 11.3 & 35.5 & \\
\hline inaktív & 9.6 & 9.9 & 6.5 & 34.6 & 15.4 & \\
\hline egyéb & 4.1 & 1.5 & 0.5 & 1.3 & 2.0 & \\
\hline Apa jelen foglalkozása & & & & & & 0.238 \\
\hline $\begin{array}{l}\text { Beosztott, alkalmazott } \\
\text { (nem közszférában) }\end{array}$ & 37.8 & 35.6 & 44.0 & 24.1 & 35.4 & \\
\hline $\begin{array}{l}\text { Beosztott, alkalmazott } \\
\text { közszférában }\end{array}$ & 19.3 & 13.1 & 17.9 & 10.6 & 15.5 & \\
\hline Vezető beosztású & 7.5 & 8.9 & 9.2 & 2.5 & 7.0 & \\
\hline $\begin{array}{l}\text { Alkalmi munkából él } \\
\text { meg }\end{array}$ & 10.6 & 5.2 & 3.8 & 22.6 & 10.7 & \\
\hline $\begin{array}{l}\text { Egyéni vállalkozó, } \\
\text { társtulajdonos }\end{array}$ & 7.9 & 13.6 & 15.2 & 2.5 & 9.5 & \\
\hline nyugdíjas & 9.1 & 14.7 & 5.4 & 15.1 & 11.0 & \\
\hline inaktív & 3.9 & 2.6 & 0.5 & 13.1 & 5.1 & \\
\hline egyéb & 3.9 & 6.3 & 3.8 & 9.5 & 5.8 & \\
\hline
\end{tabular}


A screenager fiatalok inkább férfiak, városi környezetböl származnak, korcsoport szerint a 20-24 éves és főleg érettségivel rendelkezők. A szülők családi hátterére vonatkozóan az apa iskolai végzettségét, illetve foglalkozását néztük meg, mely szerint az apák is főleg érettségivel rendelkeznek, foglalkozási pozíciójukat tekintve pedig főleg alkalmazottak. A magaskultúra orientáltak csoportjára jellemző, hogy inkább lányok és főleg városban élő 20-24 éves fiatalok. Iskolai végzettségük szerint érettségivel vagy egyetemi diplomával rendelkeznek. A szülői háttérről az mondható el, hogy inkább egyetemi vagy magiszteri diplomával rendelkező szülők gyerekei tartoznak ebbe a csoportba. A mindenevő csoport tagjai inkább nők, városi származásúak, és a fiatalabb korcsoportból kerülnek ki, azaz 15-19 évesek. Az apa jelenlegi foglalkozásának elemzése alapján pedig főleg alkalmazottak, de ebbe a csoportba kerül a legtöbb vezető beosztású, illetve vállalkozó szülő gyereke is. A negyedik klaszterbe a passzívak, azaz inkább azt mondhatnánk, hogy a különböző kulturális tevékenységeket nélkülöző fiatalok tartoznak, akik társadalmi demográfiai jellemzők alapján inkább férfiak, falusi környezetben élők, életkor szerint pedig idősebbek, 2529 évesek. Iskolai végzettség szerint a legfeljebb 8 osztályt vagy szakiskolát végzettek vannak felülreprezentálva, ami hasonló eloszlást mutat az apa iskolai végzettsége esetében is. Foglalkozás szerint pedig inkább alkalmi munkából élők vagy inaktívak.

A fentiek alapján azt állíthatjuk, hogy a negyedik csoport tagjai tipikusan alacsony társadalmi státusúak, míg a második harmadik csoport tagjai inkább magasabb társadalmi státusú csoportokból kerülnek ki. Azt láthattuk, hogy a magyarázó változók közül az apa iskolai végzettsége (Cramer`s V: 0.27; Sig<0.00) illetve foglalkozása (Cramer`s V: 0.24; Sig<0.00) erős összefüggést mutat a klaszterekkel, de ugyanakkor a nem (Cramer`s V: 0.21; Sig<0.00) és az életkor (Cramer`s V: 0.19; Sig<0.00) is jelentős hatást gyakorol a csoporthovatartozásra. 


\subsection{Kulturális szegmentációt befolyásoló tényezők. Regresszió-elemzések}

\subsubsection{Logisztikus regresszióelemzés}

Először a logisztikus regresszió módszerével vizsgáltuk a magyarázó változók kulturális fogyasztásra gyakorolt hatását. Minden egyes csoportba való tartozás magyarázatára egy külön regressziós modellt futtattunk le.

A modellek függő változói: screenagerek, magaskultúra orientáltak, mindenevők, passzívak, referenciaértékeit pedig az adott csoportba nem tartozó összes többi személy jelenti.

A logisztikus regressziós modellek értékeit a 10.18. táblázat foglalja össze, melynek együtthatói úgy értelmezhetők, hogy a referencia kategóriához képest, amelyet a táblázat alján tüntettünk fel, hányszor nagyobb az esélye egy fiatalnak arra, hogy inkább a függő változó által jellemzett csoportba tartozzon, mint abból kimaradjon.

10.18. táblázat: Az egyes kulturális csoportokba való tartozást befolyásoló tényezők. Logisztikus regressziós modellek együtthatóinak exponenciális értékei Exp (b)

\begin{tabular}{|c|c|c|c|c|}
\hline Magyarázó változók & Screenagerek & $\begin{array}{c}\text { Magaskultúra } \\
\text { orientáltak }\end{array}$ & Mindenevők & Passzívak \\
\hline \multicolumn{5}{|l|}{ Apa iskolai végzettség } \\
\hline Legfeljebb 8 osztály & 0.819 n.sz & $0.091 * *$ & $0.303 * *$ & $22.135 * *$ \\
\hline Szakiskola & $2.438 * *$ & $0.290 * *$ & 0.684 n.sz & $4.099 * *$ \\
\hline Érettségi (líceum, technikum) & $2.438 * *$ & $0.363 * *$ & 0.793 n.sz & $2.730 *$ \\
\hline \multicolumn{5}{|l|}{ Apa jelenlegi foglalkozása } \\
\hline $\begin{array}{l}\text { Beosztott, alkalmazott (nem } \\
\text { közszférában) }\end{array}$ & 0.999 n.sz & $0.691 \mathrm{n} . \mathrm{sz}$ & $3.067 * *$ & $0.576^{*}$ \\
\hline $\begin{array}{l}\text { Beosztott, alkalmazott köz- } \\
\text { szférában }\end{array}$ & $1.691 \mathrm{nsz}$. & 0.493 & $2.074 *$ & 0.619 n.sz \\
\hline $\begin{array}{l}\text { Vezető beosztású, egyéni vál- } \\
\text { lalkozó, társtulajdonos }\end{array}$ & 0.936 n.sz. & 0.833 n.sz & $3.311 * *$ & $0.369^{*}$ \\
\hline Alkalmi munkából él meg & 1.069 n.sz & $0.525 \mathrm{n} . \mathrm{sz}$ & 0.836 n.sz & 1.648 n.sz \\
\hline \multicolumn{5}{|l|}{ Korcsoport } \\
\hline 15-19 évesek & 1.407 n.sz & $0.475^{* *}$ & $3.071 * *$ & $0.416^{* *}$ \\
\hline 20-24 évesek & 1.276 n.sz & 0.900 n.sz & $1.738^{*}$ & $0.511 * *$ \\
\hline \multicolumn{5}{|l|}{ Neme } \\
\hline Férfi & $2.496 * *$ & 0.725 n.sz & $0.351 * *$ & 1.217 n.sz \\
\hline Konstans & 0.113 & 1.654 & 0.157 & 0.139 \\
\hline Nagelkerke R Square & 0.108 & 0.125 & 0.193 & 0.298 \\
\hline
\end{tabular}

Referenciakategóriák: felsőfokú végzettség, nyugdíjas- inaktív, 25-29 éves, nő

$* \mathrm{p}<0,05 ; * * \mathrm{p}<0,01$. 
Elsősorban a mindenevők csoportját vizsgáltuk, nevezetesen azt, hogy milyen mértékben befolyásolja az apa iskolai végzettsége és foglalkozása, illetve a megkérdezett életkora a csoporthoz való tartozást. A logisztikus regresszió együtthatói azt mutatják, hogy az apa foglalkozása jelentős mértékben befolyásolja a mindenevők csoportjába való tartozást, vagyis azoknak a fiataloknak, akiknek az apja beosztott, vezető stb. háromszor nagyobb az esélyük arra, hogy a mindenevők csoportjába tartozzanak, szemben azokkal, akiknek az apja inaktív. Az apa iskolai végzettsége és a fiatalok csoporthovatartozása között nincs szignifikáns kapcsolat. Eredményeink szerint a mindenevők csoportjának erőteljes életkori meghatározottsága van, a 25-29 évesekhez képest háromszor nagyobb valószínüséggel tartoznak 15-19 évesek ebbe a csoportba, és közel kétszer nagyobb valószínüséggel 20-24 évesek.

A magaskultúra orientáltak csoportjába való tartozást elsősorban az apa iskolázottsága határozza meg, vagyis nagyobb eséllyel tartoznak azok a fiatalok ebbe a csoportba, akiknek édesapja magasabb iskolai végzettséggel rendelkezik.

A screenagerek csoportját ezzel ellentétben inkább demográfiai jellegzetességek mentén lehet leírni. Kétszer nagyobb eséllyel tartoznak férfiak ebbe a csoportba, de az apa iskolai végzettségét tekintve is találtunk szignifikáns összefüggéseket. A felsőfokú végzettekhez viszonyítva a szakiskolával, illetve érettségivel rendelkező szülők gyerekeinek közel háromszor akkora esélye van arra, hogy a screenagerek csoportjában tartozzon, mint egy másik csoportba.

Végül a passzívak csoportját elemezve szignifikáns kapcsolatot mutathatunk ki az apa iskolai végzettsége és a csoportba kerülés között: minél alacsonyabb az apa iskolai végzettsége, annál nagyobb az esélye a fiatalnak, hogy ebbe a csoportba kerüljön. Ezt a klasztert alacsonyabb iskolai végzettség, illetve az idősebb életkor jellemzi. Az idősebb korosztály kulturális fogyasztásban való inaktivitását egy rejtett változó is magyarázhatja: a gyerekvállalás miatti passzivitás csökkentheti egy kis időszakra a kulturális aktivitást.

\subsubsection{Multinomiális regresszióelemzés}

Az előbb alkalmazott binomiális logisztikus regresszió a klasztereket egyenként értelmezte úgy, hogy a többi klasztert figyelmen kívül hagyta. Ezt a módszert 
alapvetően akkor használjuk, ha függő változónk dichotóm, éppen ezért a klasztereket dummyztuk és külön-külön modellt építettünk fel az egyes csoportokba való tartozás magyarázatára.

Tudva azt, hogy a mi függő változónk (klaszterek) alapvetően nem egy dichotóm változó, az elemzést tovább finomítottuk és a multinomiális logisztikus regresszió módszerével is megvizsgáltuk a kulturális tevékenységeket befolyásoló tényezőket. A multinomiális regresszió szimultán módon meghatározott dichotóm függő változós logisztikus regressziós egyenletek sorozata (Moksony 2006), ahol a függő változót hasonlítjuk össze azzal a kategóriával, amit kihagytunk az elemzésből, vagyis a referencia kategóriával. Ebben az esetben a klasztereket együttesen vizsgáljuk, a mindenevő klasztert referencia kategóriaként kijelölve. A magyarázó változók hasonlóak: apa iskolai végzettsége, apa jelenlegi foglalkozása, életkor és nem. A multinominális logisztikus regressziós modell értékeit a 10.19. táblázat tartalmazza. Az együtthatók azt mutatják meg, hogy hogyan befolyásolja a magyarázó változó annak esélyét, hogy valaki a két kategória közül az egyikbe tartozik és nem a másikba.

10.19. táblázat: Az egyes kulturális csoportokba való tartozást befolyásoló tényezők. Multinominális regressziós modellek együtthatóinak exponenciális értékei Exp (b)

\begin{tabular}{|c|c|c|c|}
\hline Magyarázó változók & Screenagerek & Magaskultúra orientáltak & Mindenevők \\
\hline \multicolumn{4}{|l|}{ Apa iskolai végzettség } \\
\hline Legfeljebb 8 osztály & $0.105 * *$ & $0.019 * *$ & $0.039 * *$ \\
\hline Szakiskola & $0.538 \mathrm{nsz}$. & $0.119 * *$ & $0.205^{* *}$ \\
\hline Érettségi (líceum, technikum) & 0.743 n.sz & $0.197 * *$ & $0.324 *$ \\
\hline \multicolumn{4}{|l|}{ Apa jelenlegi foglalkozása } \\
\hline $\begin{array}{l}\text { Beosztott, alkalmazott (nem köz- } \\
\text { szférában) }\end{array}$ & $1.556 \mathrm{nsz}$ & $1.205 \mathrm{nsz}$ & $3.3874 * *$ \\
\hline Beosztott, alkalmazott közszférában & $1.986 \mathrm{nsz}$. & $0.831 \mathrm{nsz}$ & $2.577 *$ \\
\hline $\begin{array}{l}\text { Vezető beosztású, egyéni vállal- } \\
\text { kozó, társtulajdonos }\end{array}$ & 2.225 n.sz & $2.078 \mathrm{nsz}$. & $6.073 * *$ \\
\hline Alkalmi munkából él meg & 0.754 n.sz & $0.427^{*}$ & $0.615 \mathrm{nsz}$. \\
\hline \multicolumn{4}{|l|}{ Korcsoport } \\
\hline 15-19 évesek & $2.455^{* *}$ & $1.163 \mathrm{nsz}$. & $4.721 * *$ \\
\hline 20-24 évesek & $1.955^{* *}$ & $1.595 \mathrm{nsz}$. & $2.709^{* *}$ \\
\hline \multicolumn{4}{|l|}{ Neme } \\
\hline Férfi & $1.472 *$ & $0.613 *$ & $0.355^{* *}$ \\
\hline Nagelkerke R Square & 0.339 & 0.339 & 0.339 \\
\hline
\end{tabular}

Referenciakategóriák: felsőfokú végzettség (BA, MA, PhD), nyugdíjas, inaktív vagy egyéb, 2529 éves, nö, 4-es klaszter (Passzívak)

$* \mathrm{p}<0,05 ; * * \mathrm{p}<0,01$. 
Az életkori sajátosságok ebben az esetben is erőteljesen befolyásolják a csoporthovatartozást. A multinominális regressziós modell értelmezése szerint az életkornak van a legnagyobb hatása a csoporthovatartozás tekintetében. A fiataloknak (15-19 éveseknek) az idősebbekhez (25-29 évesekhez) képest két és félszeres az esélye arra, hogy a 4. klaszter (passzívak) helyett az 1. klaszterbe (screenagerek) tartozzanak, közel ötszörös az esélyük, hogy a hármasba, vagyis a mindenevők csoportjában tartozzanak, mindezt úgy, hogy a többi tényező hatását, mint az apa iskolai végzettségét és foglalkozását is figyelembe vettük.

Az apa iskolai végzettsége is szignifikáns összefüggést mutat a csoporthovatartozással: minél magasabb az apa iskolai végzettsége annál nagyobb az esélye annak, hogy a megkérdezett a magas kultúra orientáltak, illetve a mindenevők csoportjába tartozzon. Az eredményeink ez esetben is összecsengenek az individualizációs hipotézissel, mely szerint a mai modern fogyasztói társadalomban kialakuló társadalmi csoportokat (miliőket) inkább az életkor és a képzettség (Schulze 2000) határozza meg.

A foglakozás a mindenevők esetében mutat szignifikáns kapcsolatot, mely szerint, ha az apa vezető pozíciót tölt be, a megkérdezett annál nagyobb valószínüséggel tartozik a mindenevők csoportjába. Azon megkérdezetteknek, akiknek az apja vezető beosztású vagy egyéni vállalkozó, hatszoros az esélye arra, hogy a 4. (passzívak) klaszter helyett a mindenevők csoportjába tartozzon, illetve akiknek az apja beosztott, de nem közszférában, az háromszoros eséllyel kerül inkább a mindenevő klaszterbe.

Összességében azt mondhatjuk, hogy az passzívakhoz (referenciakategória) képest egy magas iskolai végzettséggel rendelkező apa gyermeke nagyobb eséllyel screeneger, nagyobb eséllyel fogyaszt magaskultúrát, és még nagyobb eséllyel lesz mindenevő, továbbá egy vezető beosztású apa gyermekének a legnagyobb az esélye arra, hogy a mindenevők csoportjába tartozzon.

Mindkét módszer, a logisztikus és a multinomiális regresszió is ahhoz a következtetéshez vezet, hogy a mindenevők csoportjába tartozást leginkább a foglalkozási pozíció és az életkor határozza meg, de ugyanakkor az iskolázottság is befolyásoló tényező. Ez megegyezik Chan és Goldthorpe (2007, 2010) megállapításaival, mely 
szerint az exkluzív (magas)kultúrafogyasztók mellett jól láthatóan megjelennek a mindenevők, akik magas státusú, felsőfokú végzetséggel rendelkező fiatalok.

\subsubsection{Ordinális regresszióelemzés}

Az előző fejezetben, a kutatási kérdéseink megválaszolásához klaszterelemzés segítségével, négy látens csoportot hoztunk létre a „screenagerek”, „magaskultúra orientáltak”, „mindenevők”, és „,nélkülözők” csoportját, és ezen csoportokat vizsgáltuk elöször a logisztikus regresszió módszerével. Minden csoport magyarázatára különkülön regressziós modellt futtattunk le, melynek egyik hátránya, hogy a klasztereket egyenként értelmezi úgy, hogy a többi klasztert figyelmen kívül hagyja. A második módszerünk a multinomiális regressziós modell volt, mely segítségével a klasztereket együttesen vizsgáltuk, egyiket referencia kategóriának titulálva. Mindkét elemzés, a lineáris és a multinomiális regressziós modellek egyik hátránya, hogy csak látens változókat vizsgál és bár mindkét módszerrel hasonló válaszokat kaptunk, mégis fontosnak tartottuk, hogy a nyers itemeket is megvizsgáljuk. Mivel a korábbi elemzések szerint (Peterson-Simkus, 1992) a zenei preferenciák ideális magyarázó változónak minősülnek az „omnivore-univore” elmélet teszteléséhez, most erre fókuszálva vizsgáljuk hipotézisünket. Két itemet választottunk ki, a kulturális tevékenységek közül egy magas kultúrát képviselő (Milyen gyakran szoktál hangversenyre, operába járni?) illetve egy populáris kultúrát képviselő Milyen gyakran szoktál klubokba, partykra járni?) tevékenységet és ezeket vetettük vizsgálat tárgyává ordinális regressziós modell segítségével. Arra voltunk kíváncsiak, hogy a két tevékenység hogyan viszonyul egymáshoz, találunk-e valamiféle folytonos gyakoriságot, ami mindkét tevékenységre jellemző, vagyis, hogy a magyarázó változók ugyanúgy vagy ellentétes módon befolyásolják a tömeg és a magaskultúra fogyasztását.? Azt feltételeztük, amennyiben a tradicionális magaskultúra elmélet érvényes a kulturális fogyasztásra, akkor ahogy a társadalmi státus növekszik, úgy növekszik az operába járás gyakorisága és csökken a partyzás esélye. A rendezett logit modellt vagy más szóval ordinális regresszió választása akkor célszerü, ha a függő változónk kategóriái rangsorolhatók, melynek lényege, hogy a kategorikus függő változó egy folytonos, de rejtőzködő változó értékeit méri. 
10.20. táblázat: Ordinális regresszió koefficiensei

\begin{tabular}{|l|c|c|}
\hline \multicolumn{1}{|c|}{ Magyarázó változók } & $\begin{array}{c}\text { Milyen gyakran szoktál hang- } \\
\text { versenyre operába járni? }\end{array}$ & $\begin{array}{c}\text { Milyen gyakran szoktál } \\
\text { klubokba partykra járni? }\end{array}$ \\
\hline Apa iskolai végzettség & $-2.092^{* *}$ & $-1.802^{* *}$ \\
\hline Legfeljebb 8 osztály & $-0.996^{* *}$ & $-0.239 \mathrm{nsz}$. \\
\hline Szakiskola & $-0.441^{* *}$ & $-0.152 \mathrm{nsz}$. \\
\hline Érettségi (líceum, technikum) & & $0.630^{* *}$ \\
\hline Apa jelenlegi foglalkozása & $0.323 \mathrm{nsz}$. \\
\hline $\begin{array}{l}\text { Beosztott, alkalmazott (nem közszfé- } \\
\text { rában) }\end{array}$ & $0.191 \mathrm{nsz}$. & $0.225 \mathrm{nsz}$. \\
\hline Beosztott, alkalmazott közszférában & $0.260 \mathrm{nsz}$. & $0.676^{* *}$ \\
\hline $\begin{array}{l}\text { Vezetö beosztású, egyéni vállalkozó, } \\
\text { társtulajdonos }\end{array}$ & $-0.182 \mathrm{nsz}$. & $-0.360 \mathrm{nsz}$. \\
\hline Alkalmi munkából él meg & & $0.573^{* *}$ \\
\hline Korcsoport & $-0.113 \mathrm{nsz}$. & $0.522^{* *}$ \\
\hline $15-19$ évesek & $0.016 \mathrm{nsz}$. & 0.162 \\
\hline 20-24 évesek & & \\
\hline & 0.088 & \\
\hline Nagelkerke $R$ Square & & \\
\hline
\end{tabular}

Referenciakategóriák: felsőokú végzettség (BA, MA, PhD), nyugdíjas, inaktív vagy egyéb, 25-29 évesek. (Nélkülözők)

$* \mathrm{p}<0,05 ; * * \mathrm{p}<0,01$.

A 10.20. táblázat koefficiensei azt mutatják, hogy az apa iskolai végzettsége növeli mind az operába járás, mind pedig a partyzás látens gyakoriságát, pontosabban a legfeljebb 8 osztályt végzettek körében az operában járás, illetve partykon való részvétel látens gyakorisága két egységgel kevesebb mint a felsőfokú végzettek körében. Azt feltételezhetjük, hogy nagy valószínüséggel ugyanazok járnak színházba is, akik partykra, klubokba, vagyis azok, akik magasabb kulturális tőkével (iskolai végzettséggel) rendelkeznek.

Az apa foglalkozása, illetve az életkor csupán a partyra járás esetében mutat szignifikáns összefüggést, de hasonlóképpen azt mondhatjuk, hogy a partyzás kumulált esélyeit kissé növeli az apa foglalkozási pozíciója és a megkérdezett életkora: a 15-19 évesek partyzási látens gyakorisága fél egységnyivel több mint a 25-29 éveseké. Elemzésünk azt mutatja, hogy együttjárás van a két kulturális tevékenység tekintetében, akik hangversenyre, operában járnak, azok járnak klubokba és partykra is, ami az „omnivore-univore” elmélet érvényességét erősíti. 


\subsection{Hierarchikus klaszterelemzés,}

\section{Ward módszer. Táblázatok, ábrák}

10.5. ábra: Klaszterkönyök. Koefficiensek ábrázolása az összevonás lépései függvényében (saját szerkesztés).

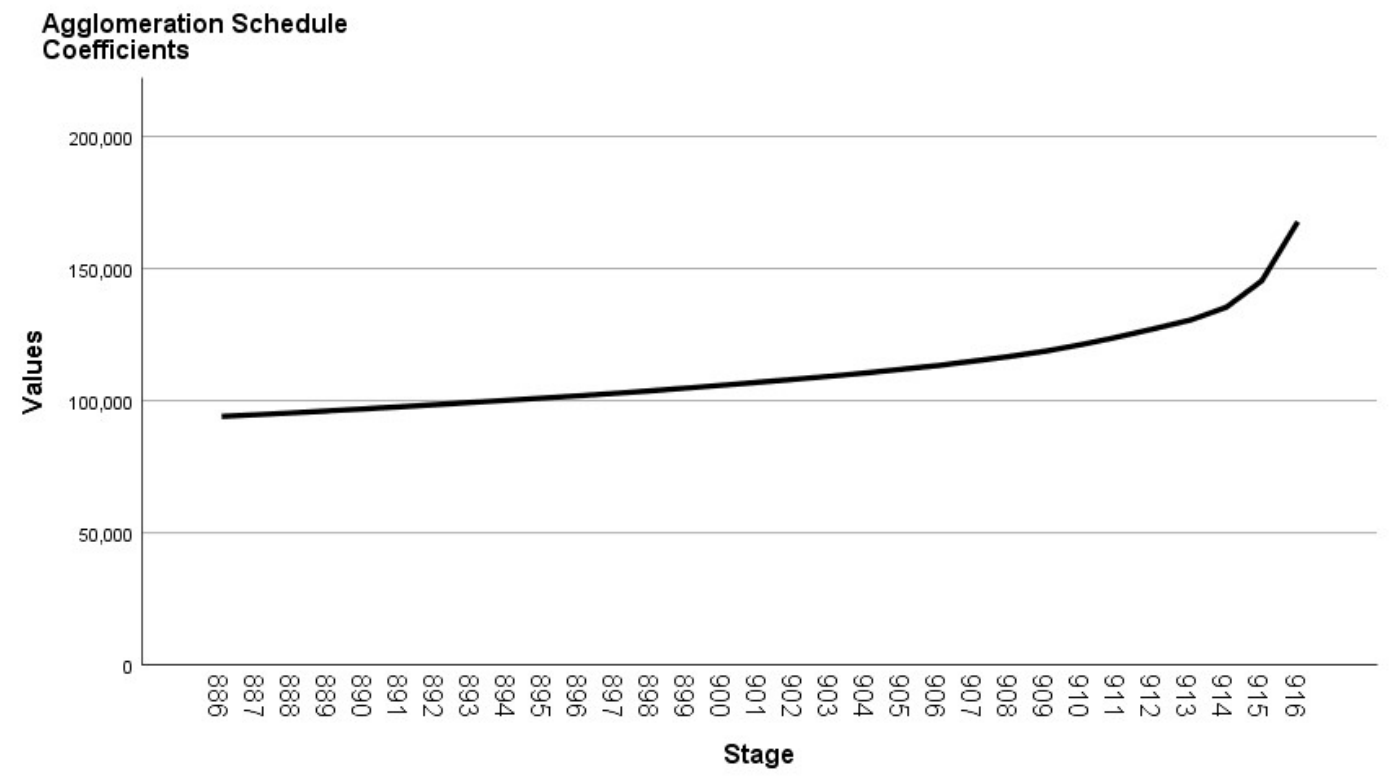


10.6. ábra: A Ward eljárás dendogramja (saját szerkesztés)

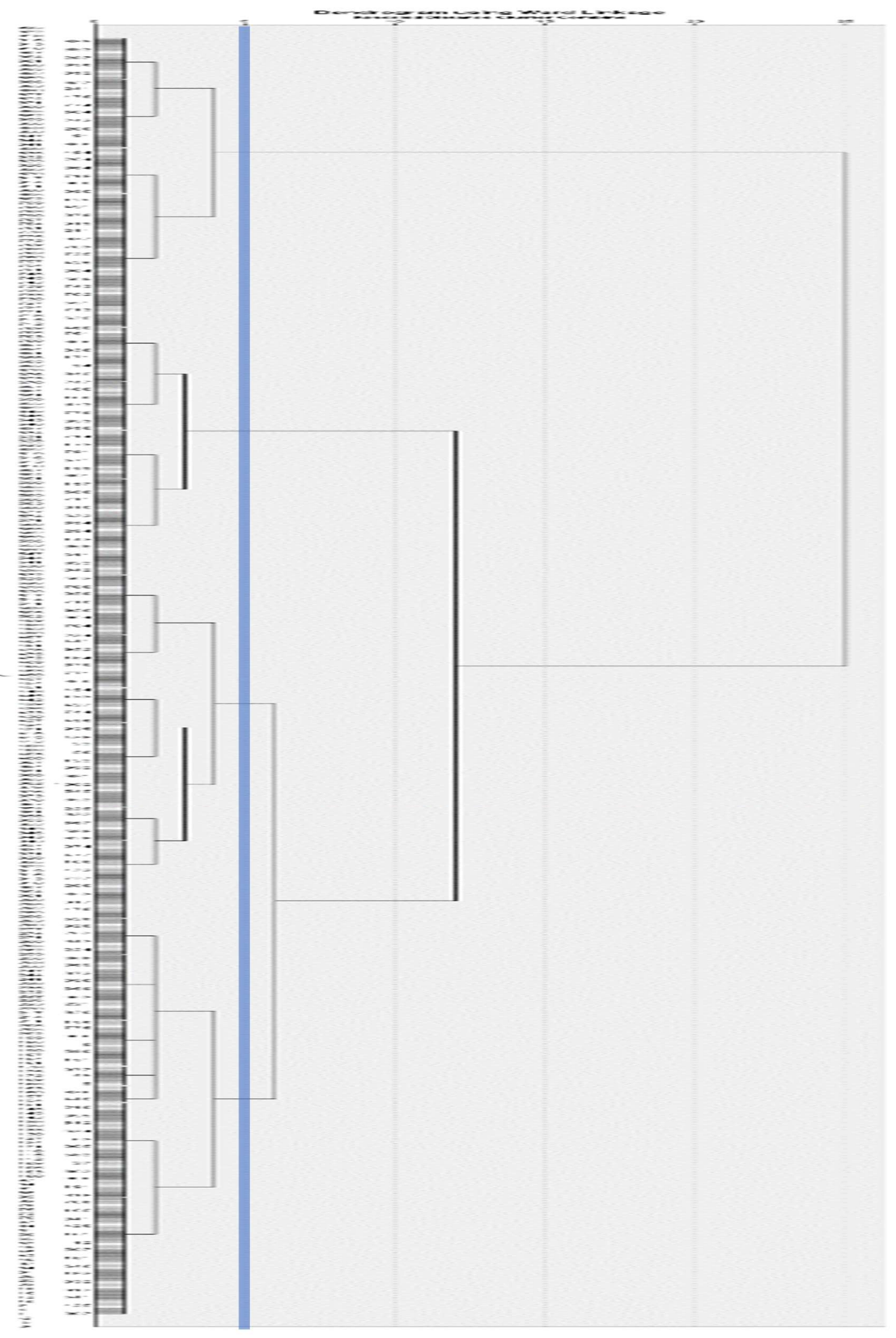


10.21. táblázat: Kulturális aktivitások gyakorisága-fogyasztási szegmensek szerint (\%).

\section{3 klaszteres megoldás Ward módszerrel}

\begin{tabular}{|l|c|c|c|c|}
\hline & $5.9 \%$ & $18.3 \%$ & $25.8 \%$ & Együtt \\
\hline kirándulni a természetbe & 75.2 & 88.7 & 34.6 & 67.2 \\
\hline könyvtárba járni & 24.6 & 46.2 & 1.7 & 22.7 \\
\hline zenélni/festeni/rajzolni & 46.8 & 59.5 & 7.6 & 39.0 \\
\hline facebookon/twitteren lógni, posztolni & 89.3 & 98.8 & 54.9 & 82.2 \\
\hline színházba járni & 31.6 & 73.8 & 3.4 & 32.0 \\
\hline hangversenyre, operába járni & 7.8 & 27.8 & 0.4 & 9.6 \\
\hline táncházba járni & 13.5 & 41.7 & 3.4 & 16.0 \\
\hline filmeket nézni otthon (PC/Laptop/Tablet) & 89.5 & 92.9 & 52.3 & 80.5 \\
\hline írni (blogot, verset, prózát) & 13.8 & 28.4 & 1.3 & 13.3 \\
\hline könyvet olvasni & 49.7 & 82.7 & 8.9 & 45.3 \\
\hline sportolni, kocogni & 65.7 & 87.5 & 18.2 & 57.5 \\
\hline tévét nézni & 62.8 & 68.5 & 70.8 & 65.9 \\
\hline zenét hallgatni & 95.3 & 99.4 & 82.6 & 92.8 \\
\hline $\begin{array}{l}\text { újságot, } \\
\text { híreket olvasni }\end{array}$ & 55.4 & 83.3 & 16.9 & 50.6 \\
\hline híreket olvasni online & 65.1 & 90.5 & 14.4 & 56.7 \\
\hline online játékot használni & 36.6 & 35.7 & 12.3 & 30.2 \\
\hline barátokkal együtt lógni, beszélgetni & 92.0 & 98.2 & 66.1 & 86.5 \\
\hline kocsmába/sörözöbe/borozóba járni & 49.9 & 77.4 & 22.0 & 47.8 \\
\hline moziba járni & 25.3 & 58.3 & 3.0 & 25.6 \\
\hline klubokba, partykra járni & 42.9 & 85.1 & 5.5 & 41.0 \\
\hline szakkörön, képzéseken részt venni & 21.4 & 56.5 & 2.1 & 22.9 \\
\hline szoláriumba járni & 5.6 & 16.1 & 0.8 & 6.3 \\
\hline kozmetikushoz, fodrászhoz járni & 31.0 & 66.7 & 17.3 & 34.0 \\
\hline uszodába vagy szaunába járni & 19.5 & 46.2 & 1.7 & 19.8 \\
\hline fitness-szalonba, kondi-terembe járni & 21.6 & 92.9 & 25.0 & 64.7 \\
\hline chatelni & 73.7 & 16.5 & 38.8 \\
\hline plázába járni & & & \\
\hline
\end{tabular}


10.22. táblázat: Társadalmi demográfiai csoportok kulturális klasztereken belüli aránya (\%) 3 klaszteres megoldás Ward módszerrel

\begin{tabular}{|c|c|c|c|c|c|}
\hline & & $\begin{array}{c}\text { Minden- } \\
\text { evők }\end{array}$ & $\begin{array}{c}\text { Passzí- } \\
\text { vak }\end{array}$ & Együtt & $\begin{array}{c}\text { Cramer's } \\
\text { V }\end{array}$ \\
\hline $\mathrm{Nem}$ & & & & & 0.161 \\
\hline Nö & 42.9 & 64.5 & 49.8 & 48.6 & \\
\hline Férfi & 57.1 & 35.5 & 50.2 & 51.4 & \\
\hline Településtípus & & & & & 0.199 \\
\hline Falu & 45.4 & 42.6 & 67.4 & 50.5 & \\
\hline Város & 54.6 & 57.4 & 32.6 & 49.5 & \\
\hline Korcsoport & & & & & 0.148 \\
\hline 15-19 évesek & 54.6 & 57.4 & 32.6 & 49.5 & \\
\hline 20-24 évesek & 36.8 & 41.7 & 30.9 & 36.2 & \\
\hline 25-29 évesek & 34.1 & 20.2 & 49.6 & 35.6 & \\
\hline Iskolai végzettség & & & & & 0.213 \\
\hline Legfeljebb 8 osztály & 24.6 & 21.9 & 43.2 & 28.9 & \\
\hline Szakiskola & 9.0 & 5.9 & 20.8 & 11.4 & \\
\hline Érettségi (líceum, technikum) & 36.3 & 41.4 & 25.0 & 34.3 & \\
\hline $\mathrm{BA}, \mathrm{MA}, \mathrm{PhD}$ & 30.2 & 30.8 & 11.0 & 25.4 & \\
\hline Apa iskolai végzettség & & & & & 0.297 \\
\hline Legfeljebb 8 osztály & 6.6 & 3.3 & 37.1 & 13.4 & \\
\hline Szakiskola & 36.3 & 30.1 & 32.7 & 34.3 & \\
\hline Érettségi (líceum, technikum) & 38.4 & 48.4 & 25.2 & 37.0 & \\
\hline $\mathrm{BA}, \mathrm{MA}, \mathrm{PhD}$ & 18.7 & 18.3 & 5.0 & 15.3 & \\
\hline Foglalkozás & & & & & 0.315 \\
\hline Beosztott, alkalmazott (nem közszférában) & 26.9 & 19.9 & 23.0 & 24.6 & \\
\hline Beosztott, alkalmazott közszférában & 13.6 & 7.2 & 11.7 & 12.0 & \\
\hline Vezető beosztású & 3.2 & 3.6 & 0.4 & 2.5 & \\
\hline Alkalmi munkából él meg & 3.6 & 2.4 & 10.9 & 5.2 & \\
\hline Egyéni vállalkozó, társtulajdonos & 3.0 & 0.0 & 3.5 & 2.5 & \\
\hline Tanuló, egyetemista & 37.5 & 60.8 & 13.5 & 35.7 & \\
\hline inaktív & 10.1 & 4.8 & 35.2 & 15.5 & \\
\hline egyéb & 2.2 & 1.2 & 1.7 & 1.9 & \\
\hline Apa jelenlegi foglalkozása & & & & & 0.262 \\
\hline Beosztott, alkalmazott (nem közszférában) & 37.3 & 45.8 & 23.0 & 35.4 & \\
\hline Beosztott, alkalmazott közszférában & 16.2 & 17.0 & 12.5 & 15.5 & \\
\hline Vezető beosztású & 7.2 & 10.5 & 3.0 & 6.8 & \\
\hline Alkalmi munkából él meg & 8.2 & 4.6 & 21.0 & 10.6 & \\
\hline Egyéni vállalkozó, társtulajdonos & 11.4 & 13.1 & 2.5 & 9.6 & \\
\hline nyugdíjas & 11.2 & 4.6 & 16.0 & 11.1 & \\
\hline Inaktív, egyéb & 8.5 & 4.6 & 22.0 & 11.0 & \\
\hline
\end{tabular}


10.23. táblázat: Kulturális aktivitások gyakorisága - fogyasztási szegmensek szerint (\%).

\section{4 klaszteres megoldás Ward módszerrel}

\begin{tabular}{|l|c|c|c|c|c|}
\hline & $30 \%$ & $18.3 \%$ & $25.9 \%$ & $25.8 \%$ & Együtt \\
\hline kirándulni a természetbe & 78.2 & 88.7 & 71.8 & 34.6 & 67.2 \\
\hline könyvtárba járni & 31.6 & 46.2 & 16.4 & 1.7 & 22.7 \\
\hline zenélni/festeni/rajzolni & 55.3 & 59.5 & 37.1 & 7.6 & 39.0 \\
\hline $\begin{array}{l}\text { facebookon/twitteren lógni, posz- } \\
\text { tolni }\end{array}$ & 83.3 & 98.8 & 96.2 & 54.9 & 82.2 \\
\hline színházba járni & 39.6 & 73.8 & 22.3 & 3.4 & 32.0 \\
\hline hangversenyre, operába járni & 10.5 & 27.8 & 4.6 & 0.4 & 9.6 \\
\hline táncházba járni & 19.3 & 41.7 & 6.7 & 3.4 & 16.0 \\
\hline $\begin{array}{l}\text { filmeket nézni otthon (PC/Lap- } \\
\text { top/Tablet) }\end{array}$ & $85.1 \%$ & 92.9 & 95.0 & 52.3 & 80.6 \\
\hline írni (blogot, verset, prózát) & 17.1 & 28.4 & 10.1 & 1.3 & 13.3 \\
\hline könyvet olvasni & 60.0 & 82.7 & 37.8 & 8.9 & 45.3 \\
\hline sportolni, kocogni & 64.4 & 87.5 & 67.2 & 18.2 & 57.5 \\
\hline tévét nézni & 44.4 & 68.5 & 84.0 & 70.8 & 65.9 \\
\hline zenét hallgatni & 93.1 & 99.4 & 98.3 & 82.6 & 92.9 \\
\hline $\begin{array}{l}\text { újágot, } \\
\text { híreket olvasni }\end{array}$ & 60.1 & 83.3 & 49.6 & 16.9 & 50.5 \\
\hline híreket olvasni online & 72.0 & 90.5 & 57.4 & 14.4 & 56.8 \\
\hline online játékot használni & 30.1 & 35.7 & 44.3 & 12.3 & 30.2 \\
\hline barátokkal együtt lógni, beszélgetni & 87.6 & 98.2 & 97.5 & 66.1 & 86.6 \\
\hline kocsmába/sörözöbe/borozóba járni & 43.3 & 77.4 & 57.6 & 22.0 & 47.8 \\
\hline moziba járni & 27.6 & 58.3 & 22.8 & 3.0 & 25.7 \\
\hline klubokba, partykra járni & 30.2 & 85.1 & 57.6 & 5.5 & 41.0 \\
\hline szakkörön, képzéseken részt venni & 28.7 & 56.5 & 13.0 & 2.1 & 22.9 \\
\hline szoláriumba járni & 8.4 & 16.1 & 2.1 & 0.8 & 6.2 \\
\hline kozmetikushoz, fodrászhoz járni & 31.6 & 66.7 & 30.3 & 17.3 & 34.0 \\
\hline uszodába vagy szaunába járni & 27.6 & 46.2 & 10.1 & 1.7 & 19.8 \\
\hline $\begin{array}{l}\text { fitness-szalonba, kondi-terembe } \\
\text { járni }\end{array}$ & 31.3 & 36.7 & 10.5 & 1.3 & 19.2 \\
\hline chatelni & 59.8 & 92.9 & 89.9 & 25.0 & 64.7 \\
\hline plázába járni & 32.4 & 75.7 & 42.6 & 16.5 & 38.9 \\
\hline
\end{tabular}




\subsection{4. táblázat: Társadalmi demográfiai csoportok kulturális klasztereken belüli aránya}

(\%) 4 klaszteres megoldás Ward módszerrel

\begin{tabular}{|c|c|c|c|c|c|c|}
\hline & $\begin{array}{l}\text { Magaskultúra ori- } \\
\text { entáltak }\end{array}$ & $\begin{array}{l}\text { Minden- } \\
\text { evők }\end{array}$ & $\begin{array}{l}\text { Screenage- } \\
\text { rek }\end{array}$ & $\begin{array}{l}\text { Passzí- } \\
\text { vak }\end{array}$ & Együtt & $\begin{array}{c}\text { Cramer`s } \\
\text { V }\end{array}$ \\
\hline $\mathrm{Nem}$ & & & & & & 0.187 \\
\hline Nö & 48.7 & 64.5 & 36.1 & 49.8 & 48.6 & \\
\hline Férfi & 51.3 & 35.5 & 63.9 & 50.2 & 51.4 & \\
\hline Településtípus & & & & & & 0.209 \\
\hline Falu & 41.5 & 42.6 & 50.0 & 67.4 & 50.5 & \\
\hline Város & 58.5 & 57.4 & 50.0 & 32.6 & 49.5 & \\
\hline Korcsoport & & & & & & 0.180 \\
\hline 15-19 évesek & 21.1 & 38.1 & 38.1 & 19.5 & 28.2 & \\
\hline 20-24 évesek & 38.9 & 41.7 & 34.7 & 30.9 & 36.3 & \\
\hline 25-29 évesek & 40.0 & 20.2 & 27.2 & 49.6 & 35.5 & \\
\hline Iskolai végzettség & & & & & & 0.221 \\
\hline Legfeljebb 8 osztály & 19.3 & 21.9 & 30.7 & 43.2 & 28.9 & \\
\hline Szakiskola & 4.0 & 5.9 & 14.3 & 20.8 & 11.3 & \\
\hline $\begin{array}{l}\text { Érettségi (líceum, tech- } \\
\text { nikum) }\end{array}$ & 34.5 & 41.4 & 38.2 & 25.0 & 34.3 & \\
\hline $\mathrm{BA}, \mathrm{MA}, \mathrm{PhD}$ & 42.2 & 30.8 & 16.8 & 11.0 & 25.5 & \\
\hline Apa iskolai végzettség & & & & & & 0.253 \\
\hline Legfeljebb 8 osztály & 5.6 & 3.3 & 7.7 & 37.1 & 13.4 & \\
\hline Szakiskola & 33.2 & 30.1 & 40.3 & 32.7 & 34.4 & \\
\hline $\begin{array}{l}\text { Érettségi (líceum, tech- } \\
\text { nikum) }\end{array}$ & 37.2 & 48.4 & 39.8 & 25.2 & 37.0 & \\
\hline $\mathrm{BA}, \mathrm{MA}, \mathrm{PhD}$ & 24.0 & 18.3 & 12.2 & 5.0 & 15.1 & \\
\hline Foglalkozás & & & & & & 0.272 \\
\hline $\begin{array}{l}\text { Beosztott, alkalmazott } \\
\text { (nem közszférában) }\end{array}$ & 26.8 & 19.9 & 26.9 & 23.0 & 24.6 & \\
\hline $\begin{array}{l}\text { Beosztott, alkalmazott } \\
\text { közszférában }\end{array}$ & 18.4 & 7.2 & 7.7 & 11.7 & 11.9 & \\
\hline Vezető beosztású & 3.3 & 3.6 & 3.0 & 0.4 & 2.5 & \\
\hline $\begin{array}{l}\text { Alkalmi munkából él } \\
\text { meg }\end{array}$ & 2.9 & 2.4 & 4.3 & 10.9 & 5.2 & \\
\hline $\begin{array}{l}\text { Egyéni vállalkozó, társ- } \\
\text { tulajdonos }\end{array}$ & 4.0 & 0.0 & 1.7 & 3.5 & 2.5 & \\
\hline Tanuló, egyetemista & 33.5 & 60.8 & 42.3 & 13.5 & 35.7 & \\
\hline inaktív & 9.6 & 4.8 & 10.7 & 35.2 & 15.5 & \\
\hline egyéb & 1.5 & 1.2 & 3.4 & 1.7 & 2.0 & \\
\hline $\begin{array}{l}\text { Apa jelenlegi foglalko- } \\
\text { zása }\end{array}$ & & & & & & 0.232 \\
\hline $\begin{array}{l}\text { Beosztott, alkalmazott } \\
\text { (nem közszférában) }\end{array}$ & 33.7 & 45.8 & 41.6 & 23.0 & 35.5 & \\
\hline $\begin{array}{l}\text { Beosztott, alkalmazott } \\
\text { közszférában }\end{array}$ & 16.3 & 17.0 & 16.3 & 12.5 & 15.5 & \\
\hline Vezető beosztású & 7.9 & 10.5 & 6.3 & 3.0 & 6.8 & \\
\hline $\begin{array}{l}\text { Alkalmi munkából él } \\
\text { meg }\end{array}$ & 5.2 & 4.6 & 11.3 & 21.0 & 10.5 & \\
\hline $\begin{array}{l}\text { Egyéni vállalkozó, társ- } \\
\text { tulajdonos }\end{array}$ & 13.5 & 13.1 & 9.0 & 2.5 & 9.6 & \\
\hline nyugdijas & 15.1 & 4.6 & 6.8 & 16.0 & 11.1 & \\
\hline Inaktív, egyéb & 8.4 & 4.6 & 8.0 & 22.0 & 11.0 & \\
\hline
\end{tabular}


10.25. táblázat: Kulturális aktivitások gyakorisága-fogyasztási szegmensek szerint (\%).

\section{5 klaszteres megoldás Ward módszerrel}

\begin{tabular}{|l|c|c|c|c|c|c|}
\hline & $14.3 \%$ & $18.3 \%$ & $25.9 \%$ & $15.7 \%$ & $25.8 \%$ & Együtt \\
\hline kirándulni a természetbe & 16.4 & 24.1 & 27.7 & 18.5 & 13.3 & 100.0 \\
\hline könyvtárba járni & 20.6 & 46.2 & 16.4 & 41.7 & 1.7 & 22.7 \\
\hline zenélni/festeni/rajzolni & 39.4 & 59.5 & 37.1 & 69.4 & 7.6 & 39.0 \\
\hline Facebookon/twitteren lógni, posztolni & 88.5 & 98.8 & 96.2 & 78.5 & 54.9 & 82.2 \\
\hline színházba járni & 45.0 & 73.8 & 22.3 & 35.2 & 3.4 & 32.1 \\
\hline hangversenyre, operába járni & 10.7 & 27.8 & 4.6 & 10.4 & 0.4 & 9.6 \\
\hline táncházba járni & 13.7 & 41.7 & 6.7 & 24.3 & 3.4 & 16.0 \\
\hline filmeket nézni otthon (PC/Laptop/Tablet) & 90.8 & 92.9 & 95.0 & 79.9 & 52.3 & 80.6 \\
\hline írni (blogot, verset, prózát) & 14.5 & 28.4 & 10.1 & 19.4 & 1.3 & 13.3 \\
\hline könyvet olvasni & 61.8 & 82.7 & 37.8 & 59.0 & 8.9 & 45.4 \\
\hline sportolni, kocogni & 76.3 & 87.5 & 67.2 & 53.1 & 18.2 & 57.4 \\
\hline tévét nézni & 39.7 & 68.5 & 84.0 & 48.6 & 70.8 & 65.9 \\
\hline zenét hallgatni & 93.9 & 99.4 & 98.3 & 92.4 & 82.6 & 92.9 \\
\hline újságot, \\
híreket olvasni & 71.8 & 83.3 & 49.6 & 49.3 & 16.9 & 50.5 \\
\hline híreket olvasni online & 84.0 & 90.5 & 57.4 & 61.1 & 14.4 & 56.8 \\
\hline online játékot használni & 49.6 & 35.7 & 44.3 & 11.8 & 12.3 & 30.1 \\
\hline barátokkal együtt lógni, beszélgetni & 90.1 & 98.2 & 97.5 & 85.4 & 66.1 & 86.6 \\
\hline kocsmába/sörözöbe/borozóba járni & 61.1 & 77.4 & 57.6 & 27.1 & 22.0 & 47.8 \\
\hline moziba járni & 48.9 & 58.3 & 22.8 & 8.3 & 3.0 & 25.7 \\
\hline klubokba, partykra járni & 39.7 & 85.1 & 57.6 & 21.5 & 5.5 & 41.0 \\
\hline szakkörön, képzéseken részt venni & 24.4 & 56.5 & 13.0 & 32.6 & 2.1 & 22.9 \\
\hline szoláriumba járni & 13.7 & 16.1 & 2.1 & 3.5 & 0.8 & 6.2 \\
\hline kozmetikushoz, fodrászhoz járni & 43.5 & 66.7 & 30.3 & 20.8 & 17.3 & 34.0 \\
\hline uszodába vagy szaunába járni & 45.0 & 46.2 & 10.1 & 11.8 & 1.7 & 19.8 \\
\hline fitness-szalonba, kondi-terembe járni & 52.7 & 36.7 & 10.5 & 11.8 & 1.3 & 19.2 \\
\hline chatelni & 67.2 & 92.9 & 89.9 & 52.8 & 25.0 & 64.7 \\
\hline plázába járni & 46.6 & 75.7 & 42.6 & 19.4 & 16.5 & 38.9 \\
\hline
\end{tabular}


10.26. táblázat: Társadalmi demográfiai csoportok kulturális klasztereken belüli aránya (\%) 5 klaszteres megoldás Ward módszerrel

\begin{tabular}{|c|c|c|c|c|c|c|c|}
\hline & & $\begin{array}{l}\text { Minden- } \\
\text { evök }\end{array}$ & $\begin{array}{l}\text { Screenage- } \\
\text { rek }\end{array}$ & & $\begin{array}{l}\text { Passzí- } \\
\text { vak }\end{array}$ & Együtt & Cramers V \\
\hline $\mathrm{Nem}$ & & & & & & & 0.200 \\
\hline Nő & 42.0 & 64.5 & 36.1 & 54.9 & 49.8 & 48.6 & \\
\hline Férfi & 58.0 & 35.5 & 63.9 & 45.1 & 50.2 & 51.4 & \\
\hline Településtípus & & & & & & & 0.238 \\
\hline Falu & 30.5 & 42.6 & 50.0 & 51.4 & 67.4 & 50.5 & \\
\hline Város & 69.5 & 57.4 & 50.0 & 48.6 & 32.6 & 49.5 & \\
\hline Korcsoport & & & & & & & 0.181 \\
\hline 15-19 évesek & 19.8 & 38.1 & 38.1 & 22.2 & 19.5 & 28.2 & \\
\hline 20-24 évesek & 39.7 & 41.7 & 34.7 & 38.2 & 30.9 & 39.7 & \\
\hline 25-29 évesek & 40.5 & 20.2 & 27.2 & 39.6 & 49.6 & 35.5 & \\
\hline Iskolai végzettség & & & & & & & 0.226 \\
\hline Legfeljebb 8 osztály & 20.6 & 21.9 & 30.7 & 17.5 & 43.2 & 28.8 & \\
\hline Szakiskola & 0.8 & 5.9 & 14.3 & 7.0 & 20.8 & 11.3 & \\
\hline Érettségi (líceum, technikum) & 31.3 & 41.4 & 38.2 & 37.8 & 25.0 & 34.4 & \\
\hline $\mathrm{BA}, \mathrm{MA}, \mathrm{PhD}$ & 47.3 & 30.8 & 16.8 & 37.8 & 11.0 & 25.5 & \\
\hline Apa iskolai végzettség & & & & & & & 0.260 \\
\hline Legfeljebb 8 osztály & 4.1 & 3.3 & 7.7 & 7.1 & 37.1 & 13.5 & \\
\hline Szakiskola & 25.6 & 30.1 & 40.3 & 40.2 & 32.7 & 34.3 & \\
\hline Érettségi (líceum, technikum) & 43.0 & 48.4 & 39.8 & 31.5 & 25.2 & 37.0 & \\
\hline $\mathrm{BA}, \mathrm{MA}, \mathrm{PhD}$ & 27.3 & 18.3 & 12.2 & 21.3 & 5.0 & 15.2 & \\
\hline Foglalkozás & & & & & & & 0.242 \\
\hline $\begin{array}{l}\text { Beosztott, alkalmazott (nem } \\
\text { közszférában) }\end{array}$ & 31.8 & 19.9 & 26.9 & 22.5 & 23.0 & 24.6 & \\
\hline $\begin{array}{l}\text { Beosztott, alkalmazott közszfé- } \\
\text { rában }\end{array}$ & 15.5 & 7.2 & 7.7 & 21.1 & 11.7 & 11.9 & \\
\hline Vezető beosztású & 4.7 & 3.6 & 3.0 & 2.1 & 0.4 & 2.6 & \\
\hline Alkalmi munkából él meg & 3.9 & 2.4 & 4.3 & 2.1 & 10.9 & 5.2 & \\
\hline $\begin{array}{l}\text { Egyéni vállalkozó, társtulajdo- } \\
\text { nos }\end{array}$ & 5.4 & 0.0 & 1.7 & 2.8 & 3.5 & 2.6 & \\
\hline Tanuló, egyetemista & 31.8 & 60.8 & 42.3 & 35.2 & 13.5 & 35.7 & \\
\hline inaktív & 5.4 & 4.8 & 10.7 & 13.4 & 35.2 & 15.5 & \\
\hline egyéb & 1.6 & 1.2 & 3.4 & 0.7 & 1.7 & 1.9 & \\
\hline Apa jelenlegi foglalkozása & & & & & & & 0.208 \\
\hline $\begin{array}{l}\text { Beosztott, alkalmazott (nem } \\
\text { közszférában) }\end{array}$ & 31.4 & 45.8 & 41.6 & 35.9 & 23.0 & 35.5 & \\
\hline $\begin{array}{l}\text { Beosztott, alkalmazott közszfé- } \\
\text { rában }\end{array}$ & 16.5 & 17.0 & 16.3 & 16.0 & 12.5 & 15.5 & \\
\hline Vezető beosztású & 9.9 & 10.5 & 6.3 & 6.1 & 3.0 & 6.8 & \\
\hline Alkalmi munkából él meg & 5.8 & 4.6 & 11.3 & 4.6 & 21.0 & 10.5 & \\
\hline $\begin{array}{l}\text { Egyéni vállalkozó, társtulajdo- } \\
\text { nos }\end{array}$ & 18.2 & 13.1 & 9.0 & 9.2 & 2.5 & 9.6 & \\
\hline nyugdíjas & 12.4 & 4.6 & 6.8 & 17.6 & 16.0 & 11.1 & \\
\hline Inaktív, egyéb & 5.8 & 4.6 & 8.6 & 10.7 & 22.0 & 11.0 & \\
\hline
\end{tabular}




\section{Irodalomjegyzék}

Albert, F. - Dávid, B. - Kmetty, Z. - Kristóf, L. - Róbert, P. - Szabó, A. (2017) Mapping the Post-communist Class Structure. Findings from a New Multidimensional Hungarian Class Survey. East European Politics and Societies and Cultures, XX (X), 1-22. http://dx.doi.org/https://doi.org/10.1177/0888325417739954.

Angelusz, R. (2000) A láthatóság görbe tükrei. Társadalomoptikai tanulmányok. Budapest: Új Mandátum Könyvkiadó.

Anil, K. J. (2010) Data clustering: 50 years beyond K-means. Pattern Recognition, 31 (8), 651-666. http://dx.doi.org/doi:10.1016/j.patrec.2009.09.011.

Bálint, B. - Demeter, G. (2002) Székelyföld. In Szabó, A. - Bauer, B. - Laki, L. Nemeskéri, I. (szerk.) MOZAIK 2001. Gyorsjelentés. Magyar fiatalok a Kárpát medencében. Budapest: Nemzeti Ifjúságkutató Intézet, 189-239.

Barna, G. (2011) Szabadidő, kultúra, média, internet - román és magyar fiatalok fogyasztási szokásai. In Kiss, T. - Barna, G. (szerk.) Erdélyi magyar fiatalok. Összehasonlító elemzés. Nemzeti Kisebbségkutató Intézet. Kolozsvár, 91-151.

Barna, G. - Kiss, T. (2013) Erdélyi Magyar Fiatalok. Kolozsvár: Nemzeti Kisebbségkutató Intézet.

Bauer, B. - Szabó, A. - Máder, M. - Nemeskéri, I. (2003) Ifjúsági rétegek az ezredfordulón, Új ifjúsági Szemle, 105-125.

Baumann, S. (2019) Status, stand, capital, class: what do stratified patterns of cultural tastes mean? British Journal of Sociology, 70 (3), 882-886.

Beck, U. (1999) Túl renden és osztályon? In Angelusz, R. (szerk.) A társadalmi rétegzödés komponensei. Budapest, 418-468.

Beck, U. (2004) Túl renden és osztályon? Társadalmi egyenlőtlenségek, társadalmi individualizációs folyamatok és az új társadalmi alakulatok, identitások keletkezése. In Angelusz, R. (szerk.) A társadalmi rétegződés komponensei. Budapest: Új Mandátum Könyvkiadó, 322-356.

Beck, U. (2005) Mi a globalizáció? Szeged: Belvedere.

Bennett, A. (2005) Szubkultúrák vagy neo-törzsek? A fiatalok, a stílus és a zenei ízlés közötti kapcsolat újragondolása. Replika, 53, 127-143.

Berger, V. (2008) Életstílus- és miliőkutatások a német szociológiában: a hagyományos struktúramodellek alternatívái? Elérhetö: http://replika.hu/replika/64-06 [Letöltve: 2018.10.17 ].

Berger, V. (2013) A társadalmistruktúra-elemzés dilemmái és eldőntendő kérdései. Statisztikai Szemle, 91 (3), 306-313. 
Bogdan, V. (2001) România pseudo-modernă (A pszeudo-modern Románia), Sociologie Românească (1-4), 35-69.

Bokányi, Z. - Gyorgyovich, M. - Pillók, P. (2018) Rétegek és társadalmi mobilitás a fiatal társadalmi csoportban. In Székely, L. (szerk.) Magyar Ifjúság 2016. Budapest: Kutatópont, 141-183.

Bourdieu, P. (1978a) A legitimitások hierarchiája. In Ádám, P. - Léderer, P. - Ferge, Z. (ford.) Társadalmi egyenlötlenségek újratermelödése. Budapest: Gondolat kiadó, 129-136.

Bourdieu, P. (1978b) Az osztályok pályája és a valószínűségi okság. In Ádám, P. Léderer, P. - Ferge, Z. (ford.) Társadalmi egyenlötlenségek újratermelödése. Budapest: Gondolat kiadó, 237-311.

Bourdieu, P. (1978c) Különbségek és megkülönböztetések. In Ádám, P. - Léderer, P. - Ferge, Z. (ford.) Társadalmi egyenlötlenségek újratermelödése. Budapest: Gondolat kiadó, 136-151.

Bourdieu, P. (1984) Distinction. A Social Critique of the Judgement of Taste. Harvard Univerity Press.

Bourdieu, P. (2013) A társadalmi tér és a csoportok keletkezése. In Angelusz, R. Gecser, O. - Éber, M. Á. (szerk.) Társadalmi rétegzödés olvasókönyv. Budapest: ELTE, 164-177.

Bradley, H. (2014) Class Descriptors or Class Relations? Thoughts Towards a Critique of Savage et al. Sociology, 48 (3), 429-436.

Bukodi, E. (2010) Social stratification and cultural participation in Hungary: a postcommunist pattern of consumption? In Chan, T. W. - Goldthorpe, J. (szerk.) Social Status and Cultural Consuption. Cambridge University Press, 139-168.

Chan, T. W. (2013) Understanding Cultural Omnivores: Social and Political Attitudes. Elérhető: http://users.ox.ac.uk/ sfos0006/papers/att3.pdf [Letöltve:

Chan, T. W. (2019) Understanding cultural omnivores: social and political attitudes. British Journal of Sociology, 70 (3), 784-806.

Chan, T. W. - Goldthorpe, J. (2005) The Social Stratification of Theatre, Dance and Cinema Attendance, Cultural Trends (14/3), 193-212. http://dx.doi.org/https://doi.org/10.1080/09548960500436774.

Chan, T. W. - Goldthorpe, J. (2007a) Social stratification of Cultural Consumption. The visual arts in England. Poetics, 35 (2-3), 168-190. http://dx.doi.org/https://doi.org/10.1017/cbo9780511712036.008.

Chan, T. W. - Goldthorpe, J. (2007b) The social stratification of cultural Consumption: Some Policy Implications of a Research Project, Cultural Trends (16/4), $337-384$.

Chan, T. W. - Goldthorpe, J. (2010) Social Status and Cultural Consumption. In Chan, T. W. - Goldthorpe, J. (szerk.) Social Status and Cultural Consumption. Cambridge University Press, 1-28. 
Chisholm, L. (2006) Élesebb lencse vagy új kamera? Ifjúságkutatás, ifjúság és társadalmi változás Nagy Britanniában. In Gábor, K. - Jancsák, C. (szerk.) Ifjúságszociológia. Szeged: Belvedere Meridionale, 117-155.

Clark, T. N. - Lipset, S. M. (1991) Are social classes dying?, Are social classes dying? (6(4)), 397-410. http://dx.doi.org/10.1177/026858091006004002.

Cohen, P. (1997) Subcultural Conflict and Working-class Comunity. In Gelder, K. Thornton, S. (szerk.) The Subcultures Reader. London: Routledge, 90-99.

Comșa, M. (2006) Stiluri de viaţă în România după 1989. Cluj Napoca: Presa Universitară Clujeană.

Coulangeon, P. - Roharik, I. (2014) Testing the "Omnivore/Univore" Hypothesis in a Cross-National Perspective. On the Social Meaning of Ecletism in Musical Tastes, 1-28.

Croghan, R. - Griffin, C. E. - Hunter, J. - Phoenix, A. (2006) Style failure: consumption, identity and social exclusion. Journal of Youth Studies, 9 (4), 463-478. http://dx.doi.org/10.1080/13676260600914481.

Croitoru, C. - Becut, A. (2017) Barometrul de consum cultural 2016. O radiografie a practicilor de consum cultural. București: Institutul Național pentru Cercetare și Formare Culturală.

Crompton, R. (2008) Class and Stratification. 3. kiad. Polity.

Crompton, R. - Scott, J. (2014) Introduction: the State of Class Analysis. In Crompton, R. - Devine, F. - Savage, M. - Scott, J. (szerk.) Renewing Class Analysis. Oxford: Blackwell Publishers, 1-15.

Csata, Z. (2004) Iskolázottsági esélyegyenlőtlenségek az erdélyi magyar fiatalok körében, Erdélyi Társadalom (2/1), 99-132.

Csata, Z. (2005) Az iskolázottsági esélyek társadalmi meghatározottsága az erdélyi magyar fiatalok körében. In Gábor, K. - Veres, V. (szerk.) A perifériáról a centrumba. Az erdélyi fiatalok helyzetképe az ezredforduló után. Szeged-Kolozsvár: Belvedere Meridionale, 75-108.

Csata, Z. - Dániel, B. - Kiss, D. - Ruszuly, E. - Sólyom, Z. (2009) Diplomás karrierpályák az erdélyi magyar fiatalok körében. Erdélyi Társadalom, 7 (1), 31-68.

Csata, Z. - Dániel, B. - Pop, C. (2006) Pályakezdő fiatalok a munkaerőpiacon. Erdélyi Társadalom, 4 (1), 7-27.

Csata, Z. - Magyari, T. - Veres, V. (2002) Belső-Erdély. In Szabó, A. - Bauer, B. Laki, L. - Nemeskéri, I. (szerk.) MOZAIK 2001. Gyorsjelentés. Magyar fiatalok a Kárpát medencében. Budapest: Nemzeti Ifjúságkutató Intézet, 137-189.

Csite, A. - Kovács, I. - Kristóf, L. (2006) Fogyasztói csoportok az ezredforduló Magyarországán. In Kovách, I. (szerk.) Társadalmi metszetek. Budapest: Napvilág Kiadó, 253-291. 
Devine, F. - Snee, H. (2015) Doing the Great British Class Survey. The Sociological Review, 63 (2), 240-258.

Dorling, D. (2014) Thinking about Class. Sociology, 48 (3), 452-462.

Éber, M. Á. (2015) Osztályszerkezet Magyarországon. A világrendszer-elemzés perspektivájából. Replika, 92-93 (3-4), 119-140.

Éber, M. Á. (2016) Mit tudunk a 21. század fiataljai előtt álló kihívásokról? Hozzászólás Kabai Imre és munkatársai Rétegződéskötetéhez, Replika (27, évfolyam, 96-97 szám), 191-195.

Éber, M. Á. (2020) A csepp. A félperifériás magyar társadalom osztályszerkezete. Budapest: Napvilág Kiadó.

Ercsei, K. (2006) Félsziget Fesztivál ifjúsága: Fesztiválok ifjúsága? Az iskolázottság és továbbtanulás összehasonlító vizsgálata az ifjúsági korszakváltás kontextusában. In Ercsei, K. - Veres, V. (szerk.) WEB. Fesztiválok Ifjúsága. Kolozsvár: Cova-print,1-2, 47-63.

Ercsei, K. (2015) Erdélyi magyar fiatalokkal kapcsolatos kutatások térben és időben: egy áttekintés. Erdélyi Társadalom, 13 (2), 9-33. http://dx.doi.org/10.17177/77171.153.

Ercsei, K. (2017) Ifjúságkutatás Romániában 1989-et követően. In Papp Z., A. (szerk.) Változó kisebbség. Kárpát-medencei magyar fiatalok. A GeneZYs 2015 kutatás eredményei. Budapest: Mathias Corvinus Collegium - Tihanyi Alapítvány Magyar Tudományos Akadémia Társadalomtudományi Kutatóközpont Kisebbségkutató Intézet, 91-133.

Ercsei, K. - Kiss, Z. - Szabó, J. (2011) Fiatalok szabadidős fogyasztása, önállósodása és jövőképe a marosvásárhelyi Félsziget vizsgálatok alapján. In Kiss, T. Barna, G. (szerk.) Erdélyi Magyar Fiatalok. Összehasonlitó elemzés. Kolozsvár: Nemzeti Kisebbségkutató Intézet, 233-261.

Erikson, R. - Goldthorpe, J. - Portocarero, L. (1988) Intergenerációs osztálymobilitás és a konvergenciatézis Anglia, Franciaország és Svédország példáján. In Róbert, P. (szerk.) A társadalmi mobilitás. Hagyományos és új megközelitések. Budapest: Új Mandátum Könyvkiadó, 220-255.

Esping-Andersen, G. (1993) Post-industrial Class Structures. InChanging Classes: Stratification and Mobility in Post-Industrial Societies. London: SAGE, 7-31.

Fábián, Z. (2015) Társadalmi rétegek, fogyasztási státuscsoportok Magyarországon. In Szívós, P. - Tóth, I. G. (szerk.) Jól nézünk ki (...?!) Háztartások helyzete a válság után. Tárki Monitor Jelentések 2014. Budapest: TÁRKI, 128-142.

Fábián, Z. - Kolosi, T. - Róbert, P. (2000) Fogyasztás és életstílus. TARKI, Társadalmi Riport, 225-259.

Fábián, Z. - Róbert, P. - Szívós, P. (1998) Anyagi-jóléti státuscsoportok társadalmi miliői. In Kolosi, T. - Tóth, I. G. - Vukovich, G. (szerk.) Társadalmi riport 1998. Budapest: TÁRKI, 72-91. 
Fekete, M. (2018) eIDÖ, AVAGY A SZABADIDŐ BEHÁLÓZÁSA. Generációs kultúrafogyasztás a digitális korban. Szeged: Belvedere Meridionale.

Fekete, M. - Prazsák, G. (2014) Kulturális kasztrendszer: Autonómia és közösségiség szerepe a fiatalok kulturális aktivitásában. In Nagy, Á. - Székely, L. (szerk.) Másodkézből - Magyar Ifjúság 2012. Budapest: Kutatópont, 195-218.

Ferge, Z. (1969) Társadalmunk rétegödése. Elvek és tények. Budapest: Közgazdasági és Jogi Könyvkiadó.

Ferge, Z. (2012) Prekariátus Magyarországon. Beszélgetés Ferge Zsuzsával. Fordulat, 19 (3), 118-126.

Flemmen, M. P. - Jarness, V. - Rosenlund, L. (2019a) Class and status: on the misconstrual of the conceptual distinction and a neo-Bourdieusian alternative. British Journal of Sociology, 70 (3), 816-866. http://dx.doi.org/https://doi.org/10.1111/1468-4446.12508.

Flemmen, M. P. - Jarness, V. - Rosenlund, L. (2019b) Omnivorousness and openness: comments to Tak Wing Chan. British Journal of Sociology, 70 (3), 807-815.

France, A. P. - Roberts, S. - Wood, B. E. (2018) Youth, social class and privilege in the antipodes: Towards a new research agenda for youth sociology. Journal of Sociology. http://dx.doi.org/10.1177/1440783318786580.

Gábor, K. (2004) Globalizáció és korszakváltás. In Gábor, K. - Jancsák, Cs. (szerk.) Ifjúsági korszakváltás. Ifjúság az új évezredben. Szeged: Belvedere, 28-72.

Gábor, K. (2005) A perifériáról a centrumba. Előzetes hipotézisek a határon túli magyar fiatalok helyzetének az értelmezéséhez. In Gábor, K. - Veres, V. (szerk.) $A$ perifériáról a centrumba. Az erdélyi fiatalok helyzetképe az ezredforduló után. Szeged-Kolozsvár: Belvedere Meridionale, 9-23.

Gábor, K. (2006a) Az ifjúsági kultúra korszakváltása (a magyar és a nyugatnémet fiatalok a nyolcvanas években). In Gábor, K. - Jancsák, Cs. (szerk.) Ifjúságszocilógia. Szeged: Belvedere, 337-351.

Gábor, K. (2006b) Ifjúsági korszakváltás, ifjúsági és politikai kultúra a kelet- és nyugat-európai fiatalok körében. In Gábor, K. - Jancsák, Cs. (szerk.) Ifjuságszociológia. Szeged: Belvedere, 351-366.

Gábor, K. - Gaul, E. - Szemerszki, M. (2006) Trendek a Sziget-kutatásban. Az új fiatal középosztály kialakulása. In Ercsei, K. - Veres, V. (szerk.) WEB. Fesztiválok ifjúsága. Kolozsvár: Cova-print,1-2, 9-34.

Gábor, K. - Veres, V. (2011) Ifjúsági korszakváltás Kelet-Európában. Az erdélyi magyar fiatalok helyzete. In Kiss, T. - Barna, G. (szerk.) Erdélyi magyar fiatalok. Összehasonlitó elemzés. Nemzeti Kisebbségkutató Intézet, 37-54.

Galasi, P. - Timár, J. - Varga, J. (2001) Pályakezdö diplomások a munkaerőpiacon. BKAE Emberi Erőforrások Tanszék. Budapest. 
Geambașu, R. (2008) Patriarchátus a háztartás falain belül és kívül. Nemi egyenlőtlenségek az erdélyi munkaeröpiacon. Erdélyi Társadalom, 6 (1-2), $117-146$.

Gerő, M. - Kovách, I. (2015) Struktúrák, egyenlőtlenségek és hálózatok. socio.hu, (3), 17-43. http://dx.doi.org/10.18030/socio.hu.2015.3.17.

Griffin, C. E. (2011) The trouble with class: researching youth, class and culture beyond the 'Birmingham School'. Journal of Youth Studies, 14 (3), 245-259. http://dx.doi.org/10.1080/13676261.2010.533757.

Hanquinet, L. (2017) Inequalities: when culture becomes a capital. In O'Brien, D. Miller, T. - Durrer, V. (szerk.) The Routledge Handbook of Global Cultural Policy. London: Routledge,.

Harcsa, I. (2016) Társadalmi tagolódás és társadalomkép kapcsolata. Néhány alapvetés és kulcskérdés az alternatív megközelítés jegyében., Replika (27, évfolyam, 96-97 szám), 173-185.

Hegedűs, A. (1966) Társadalmi struktúra és munkamegosztás, Valóság (8), 17-32.

Hradil, S. (1995) Régi fogalmak és új struktúrák. Miliő-, szubkultúra- és életstíluskutatás a'80-as években. In Andorka, R. - Hradil, S. - Peschar, L. J. (szerk.) Társadalmi rétegzödés. Budapest: Aula kiadó, 347-387.

Huszár, Á. (2012) Osztályegyenlőtlenségek. Az egyenlőtlenségek ábrázolása Magyarországon. Szociológiai Szemle, 22 (2), 4-26.

Huszár, Á. (2013a) Foglalkozási osztályszerkezet (I) - Elméletek, modellek. Statisztikai Szemle, 91 (1), 31-56.

Huszár, Á. (2013b) Foglalkozási osztályszerkezet (II.) Az osztályozás problémái. Statisztikai Szemle, 91 (2), 117-131.

Huszár, Á. (2019) Osztálytársadalom-e a magyar társadalom? Szociológiai Szemle, 29 (4), 4-32.

Jaadi, Z. (2020) A Step by Step Explanation of Principal Component Analysis. Elérhető: https://builtin.com/data-science/step-step-explanation-principal-component-analysis [Letöltve:

Kabai, I. - Iharosi, T. - Kabainé Tóth, K. (2018) A társadalmi rétegződés empirikus vizsgálata a fiatalok körében egy speciális többdimenziós modell segítségével. In Nagy, Á. (szerk.) Margón kívül. Magyar ifjúságkutatás 20016. Budapest: Excenter Kutatóközpont, 372-402.

Kacsuk, Z. (2005) Szubkultúrák, poszt-szubkultúrák és neo-törzsek. A (látványos) ifjúsági (szub)kultúrák brit kutatásának legújabb hulláma. Replika, 53, 91-110.

Kiss, T. (2014) Etnikai rétegződési rendszer Erdélyben és Romániában. A magyarok társadalmi pozíciói. REGIO, 22 (2), 187-245. 
Kiss, T. - Barna, G. (2011) Erdélyi magyar fiatalok 2008. A vizsgálatról és a kötetről. In Kiss, T. - Barna, G. (szerk.) Erdélyi magyar fiatalok. Összehasonlitó elemzés. Kolozsvár: Nemzeti Kisebbségkutató Intézet, 7-28.

Kiss, T. - Barna, G. (2012) Népszámlálás 2011. Erdélyi magyar népesedés a XXI. század első évtizedében. Demográfiai és statisztikai elemzés. Kolozsvár: Nemzeti Kisebbségkutató Intézet.

Kiss, T. - Kapitány, B. (2009) Magyarok Erdélyben: a minta kialakítása és az adatfelvétel. In Spéder, Z. (szerk.) Párhuzamok. Anyaországi és erdélyi magyarok a századfordulón. Budapest: KSH Népességtudományi Kutatóintézet,.

Kolosi, T. (2000) A terhes babapiskóta. A rendszerváltás társadalomszerkezete. Budapest: Osiris.

Kolosi, T. - Róbert, P. (2004) A magyar társadalom szerkezeti átalakulásának és mobilitásának fő folyamatai a rendszerváltás óta. In Kolosi, T. - Tóth, I. G. - Vukovich, G. (szerk.) Társadalmi Riport. Budapest: TÁRKI, 48-74.

Kovách, I. - Kuczi, T. - Jókuthy, E. (2006) Az osztályok, a társadalmi struktúra és rétegződés kutatásának állapotáról és megújításának szükségességéről. In Kovách, I. (szerk.) Társadalmi metszetek. Hatalom, érdek, individualizáció és egyenlötlenség a mai Magyarországon. Budapest: Napvilág Kiadó, 19-39.

Kovács, E. (2014) Többváltozós adatelemzés. Budapesti Corvinus egyetem: Typotex.

Kristóf, L. - Kmetty, Z. (2019) Szereti Ön Vivaldit? Zenei ízlés és társadalmi státusz. Szociológiai Szemle, 29 (2), 49-67.

Lambert, P. S. (2019) Class, status and lifestyle: on omnivores, distinction, and the measurement of social position. British Journal of Sociology, 70 (3), 887-891. http://dx.doi.org/10.1111/1468-4446.12652.

Lazăr, M. (2011) „A nők a sorozatokat, a férfiak a focit nézik.” A kulturális fogyasztás módozatainak egy tipológiája. Erdélyi Társadalom, 9 (1-2), 9-36.

Lizardo, O. (2019) Classes and classification: comment on Chan and Flemmen, Jarness and Roselund. British Journal of Sociology, 70 (3), 906-913.

Marian, V. (2008) Stratificare socială în România: O analiză de clase latente. Calitatea Vieții, XIX (3-4), 365-388.

Marian, V. (2010) Stilurile de viata in Romania postcomunsta. Ce modele comportamentale adoptăm şi de ce. Iași: Lumen.

Mills, C. (2015) The Great British Class Survey: requiescat in pace. The Sociological Review, 63 (2), 393-399.

Mills, M. - Hans-Peter, B. (2005) Globalization, uncertainty and the early life course. A theoretical framework. In Hans-Peter, B. - Klijzing, E. - Mills, M. - Kurz, K. (szerk.) Globalization, Uncertainty, and Youth in Society. Routledge,. 
Mitulescu, S. (2011) Az utóbbi évtizedek romániai ifjúságkutatásának vázlata. In Kiss, T. - Barna, G. (szerk.) Erdélyi magyar fiatalok. Összehasonlító elemzés. Kolozsvár: Nemzeti Kisebbségkutató Intézet, 29-37.

Muggleton, D. (2000) Inside Subculture. The Postmodern Meaning of Style. Oxford: Berg.

Nagy, Á. (2014a) Ifjúsági rétegek 2012. In Nagy, Á. - Székely, L. (szerk.) Másodkézből. Magyar Ifjúság 2012. Budapest: ISZT Alapítvány - Kutatópont, 29-45.

Nagy, Á. - Fazekas, A. (2016) Szabad és még szabadabb idők. Szabadidős terek és tevékenységek változása. In Nagy, Á. - Székely, L. (szerk.) Negyedszázad. Magyar Ifjúság 2012. Iuvenis Ifjúságszakmai Mühely - ISZT Alapítvány - Excenter Kutatóközpont - Új Ifjúsági Szemle Alapítvány, 202-242.

Nagy, B. (2014b) Háttérben. Kísérlet egy szervezeti nemi rend feltárására. Budapest: L`Harmattan.

Pakulski, J. - Waters, M. (1996) The death of class. London - Thousand Oaks - New Delhi: SAGE.

Papp Z., A. (2017) Az ifjúságkutatás aktuális kérdései nemzetközi színtereken. In Papp Z., A. (szerk.) Változó kisebbség. Kárpát-medencei magyar fiatalok. A GeneZYs 2015 kutatás eredményei. Budapest: Mathias Corvinus Collegium Tihanyi Alapítvány - Magyar Tudományos Akadémia Társadalomtudományi Kutatóközpont Kisebbségkutató Intézet, 13-29.

Papp Z., A. - Ferenc, V. - Márton, J. - Morvai, T. - Szerbhorváth, G. - Zsigmond, C. (2017) GeneZYs 2015: Külhoni magyar fiatalok a Kárpát medencében összefoglaló elemzés. In Papp Z., A. (szerk.) Változó kisebbség. Kárpátmedencei magyar fiatalok a GeneZYs 2015 kutatás eredményei. Budapest: Mathias Corvinus Collegium - Tihanyi Alapítvány - Magyar Tudományos Akadémia Társadalomtudományi Kutatóközpont Kisebbségkutató Intézet, 193-239.

Peterson, R. A. - Kern, R. M. (1996) Changing Highbrow Taste: From Snob to Omnivore. American Sociological Review, 61 (5), 900-907. http://dx.doi.org/10.2307/2096460.

Peterson, R. A. - Simkus, A. (1992) How musical tastes mark occupational status groups. In Lamont, M. - Fournier, M. (szerk.) Cultivating differences: Symbolic boundaries and the making of inequality. Chicago: University of Chicago Press, $152-186$.

Róbert, P. (1997) Foglalkozási osztályszerkezet: elméleti és módszertani problémák. Szociológiai Szemle, 2, 5-48.

Róbert, P. (1999) Az életstílus meghatározottságának változása, 1982-1998. Elérhető: A cikk eredetileg angol nyelven készült, s elõadás formájában elhangzott az ISA RC28 Társadalmi rétegzõdés kutatócsoport konferenciáján (Varsó, 1999. május 5-7) [Letöltve:

Róbert, P. (2014) Osztálylétszám 2014. Prezentáció. Budapest: MTA TK Politikatudományi Intézet. Elérhető: http://politologia.tk.mta.hu/uploads/files/ Osztalyletszam2014_MTATK.pdf 
Róbert, P. (2015) Osztály- és rétegződéskutatási dilemmák a magyar társadalomban., Replika (92-93), 77-93.

Roberts, S. (2010) Misrepresenting 'choice biographies'?: a reply to Woodman. Journal of Youth Studies, 13 (1), 137-149.

Rössel, J. (2005) Plurale Sozialstrukturanalyse. Eine handlungstheoretische Rekonstruktion der Grundbegriffe der Sozialstrukturanalyse. Verlag für Sozialwissenschaft. Wiesbaden.

Sági, M. (2010) Kulturális szegmentáció: „mindenevők”, „,válogatósak”, „egysíkúak” és ,nélkülözők”? Az „omnivore-univore” modell alkalmazhatósága Magyarországon. Társadalmi Riport, 10 (1), 288-311.

Sajtos, L. - Mitev, A. (2007) SPSS kutatási és adatelemzési kézikönyv. Alinea Kiadó. Budapest.

Salat, L. - Papp Z., A. - Csata, Z. - Péntek, J. (2010) Az erdélyi magyar felsőoktatás helyzete és kilátásai. In Szikszai, M. (szerk.) Az erdélyi magyar felsőoktatás helyzete és kilátásai. Támpontok egy lehetséges stratégiához. Kolozsvár: A Magyar Tudományos Akadémia Kolozsvári Területi Bizottsága, 9-125.

Sandu, D. (1996) Sociologia tranziţiei. Valori şi tipuri sociale în România. București: Editura Staff.

Savage, M. (2015) Introduction to elites From the 'problematic of the proletariat' to a class analysis of 'wealth elites'. The Sociological Review, 63 (2), 223-239.

Savage, M. - Devine, F. - Cunningham, N. - Friedman, S. - Laurison, D. - Miles, A. - Snee, H. - Taylor, M. (2014) On Social Class, Anno 2014. Sociology, 49 (6), 1011-1030.

Savage, M. - Devine, F. - Cunningham, N. - Taylor, M. - Li, Y. - Hjellbrekke, J. Le Roux, B. - Friedman, S. - Miles, A. (2013) A New Model of Social Class? Findings from the BBC's Great British Class Survey Experiment. Sociology, 47 (2), 219-250. http://dx.doi.org/10.1177/0038038513481128.

Schiferneț, C. (1999) Treizeci de ani de cercetare ştiinţifică a tineretului. Sociologie Românească , 1, 137-143.

Schulze, G. (2000) Élménytársadalom. A jelenkor kultúrszociológiája. A hétköznapi élet esztétizálodása, Szociológiai Figyelö (1-2), 135-157.

Simon, J. (2006) A klaszterelemzés alkalmazási lehetőségei a marketingkutatásban. Statisztikai Szemle, 84 (7), 627-650.

Standing, G. (2012a) Prekariátus: Lakosokból állampolgárok? Fordulat, 19 (3), 28 51.

Standing, G. (2012b) The Precariat: from denizens to citizens? Polity, 44 (4), 588608. 
Szabó, J. - Hires-László, K. (2018) Régi és új kultúra. In Székely, L. (szerk.) Magyar fiatalok a Kárpát-medencében - Magyar Ifjúság Kutatás 2016. Budapest: Kutatópont, 315-351.

Szanyi-F., E. (2018) Nemzetközi diskurzusok az ifjúságkutatásban. InMagyar fiatalok a Kárpát-medencében - Magyar Ifjúság Kutatás 2016. Budapest: Kutatópont, $11-41$.

Székely, L. (2018) Módszertani jegyzet: Magyar Ifjúság Kutatás 2016. InMagyar fiatalok a Kárpát-medencében. Magyar Ifjúság Kutatás 2016. Budapest: Kutatópont Kft,.

Székely, M. - Barna, I. (2002) Túlélőkészlet az SPSS-hez. Többváltozós elemzési technikákról társadalomkutatók számára. Budapest: Typotex Kiadó.

Szüle, B. (2019) Klaszterszám-meghatározási módszerek összehasonlítása. Statisztikai Szemle, 97 (5), 421-438.

Thornton, S. (1996) Club Cultures: Music, Media and Subcultural Capital. London: Wesleyan University Press.

Tóth, P. - Huszár, Á. (2016) Rétegződés és mobilitás: ifjúsági rétegek, mobilitási lehetőségek és stratégiák. In Nagy, Á. - Székely, L. (szerk.) Negyedszázad. Magyar Ifjúság 2012. Iuvenis Ifjúságszakmai Mühely - ISZT Alapítvány - Excenter Kutatóközpont - Új Ifjúsági Szemle Alapítvány. Budapest, 78-118.

Treiman, D. J. (1988) Iparosodás és társadalmi rétegződés. In Róbert, P. (szerk.) Társadalmi mobilitás: hagyományos és új megközelitések. Budapest: Új Mandátum Könyvkiadó, 86-111.

Veres, V. (2005) A perifériáról a centrumba. Az erdélyi fiatalok helyzetképe az ezredforduló után. Gábor, K. - Veres, V. (szerk.) . Belvedere Meridionale.

Veres, V. (2006) Középosztályosodási tendenciák vizsgálata a marosvásárhelyi Félsziget Fesztivál résztvevői körében. In Ercsei, K. - Veres, V. (szerk.) WEB Fesztiválok Ifjúsága. Kolozsvár: Cova-print,1-2, 35-47.

Veres, V. (2011) A fiatalok munkaerö-piaci helyzete, a társadalmi közérzet és a problémaérzékelés rétegspecifikus életérései. In Kiss, T. - Barna, G. (szerk.) Erdélyi Magyar Fiatalok. Összehasonlitó elemzés. Kolozsvár: Nemzeti Kisebbségkutató Intézet, 55-85.

Veres, V. (2013) Népszámlálás 2011: A népességszám, foglalkozásszerkezet és iskolázottság nemzetiség szerinti megoszlása Romániában, Erdélyi Társadalom (11/2), 23-54.

Veres, V. (2014) Társadalmi rétegződés és anyagi-jövedelmi különbségek Magyarországon és az erdélyi magyarság körében, Szociológia Szemle (24/2), 4-46.

Veres, V. (2015) Népességszerkezet és nemzetiség. Az erdélyi magyarok demográfiai képe a 2002, és 2011, évi népszámlálások tükrében. Kolozsvár: Kolozsvári Egyetemi Kiadó. 
Veres, V. (2017a) A romániai magyarok oktatási esélyegyenlőtlenségei és a felsőoktatási expanzió, a népszámlálások alapján. In Pusztai, G. - Márkus, Z. (szerk.) Szülöföldön magyarul. Iskolák és diákok a határon túl. Debreceni Egyetemi Kiadó, 187-215.

Veres, V. (2017b) ICT Use, Cultural and Leisure Lifestyles and Social Structure of Romanian Youth, in Central and Eastern European Context. Sociologie Românească, XV (1-2), 45-65.

Veres, V. (2018) Népesedés és belső vándorlás Romániában és Erdély magyarlakta területein. Korunk, 29 (4), 22-33.

Vita, E. (2014) Párkapcsolati formák és a családi életre vonatkozó elképzelések az erdélyi társadalomban, a demográfiai mutatók és értékrend tükrében. Erdélyi Társadalom, 12 (1), 45-72. http://dx.doi.org/10.17177/77171.142.

Wallace, C. (1998) Ifjúság, munka és oktatás a posztkommunista Európában: út az individualizáció felé?, Korunk, 12-24.

Warde, A. - Wright, D. - Modesto, G.-C. (2007) Understanding Cultural Omnivorousness: Or, the Myth of the Cultural Omnivore. Cultural Sociology, 1 (2), 143-164. http://dx.doi.org/10.1177/1749975507078185.

Weber, M. (1987) Gazdaság és társadalom. A megértő szociológia alapvonala. 1. Közgazdasági és Jogi Könyvkiadó.

Woodman, D. (2009) The mysterious case of the pervasive choice biography: Ulrich Beck, structure/agency, and the middling state of theory in the sociology of youth. Journal of Youth Studies, 12 (3), 243-256.

Woodman, D. (2010) Class, individualisation and tracing processes of inequality in a changing world: A reply to Steven Roberts. Journal of Youth Studies, 13 (6), 737-746.

Wright, E. O. (1985) Classes. London: Verso.

Wright, E. O. (1997) Általános keretrendszer az osztálystruktúra elemzéséhez. In Angelusz, R. (szerk.) Társadalmi rétegzödés komponensei. Budapest: Új Mandátum Könyvkiadó,.

Yoo Jin, K. - Kyoung Nan, K. (2013) Cultural Omnivores' Consumption: Strategic and Inclusively Exclusive. International Journal of Marketing, 5 (1), 118-127. http://dx.doi.org/10.5539/ijms.v5n1p118.

Zamfir, C. (1989) „Stil de viaţă şi mod de viaţă. Reflecţii actuale asupra stadiului actual al analizei sociologice”. In Rebedu, I. - Zamfir, C. (szerk.) Editura Academiei RSR. București, 35-54.

Zinnecker, J. (1993) A fiatalok a társadalmi osztályok terében. In Gábor, K. (szerk.) Civilizációs korszakváltás és ifjúság. Szeged: Szociológiai mühely, 5-28.

Zinnecker, J. (2006) A fiatalok a társadalmi osztályok terében. Új gondolatok egy régi témához. In Gábor, K. - Jancsák, Cs. (szerk.) Ifjúságszociológia. Szeged: Belvedere, 69-95. 
